\title{
Remote Sensing for Environmental Site Screening and Watershed Evaluation in Utah Mine Lands-East Tintic Mountains, Oquirrh Mountains, and Tushar Mountains
}

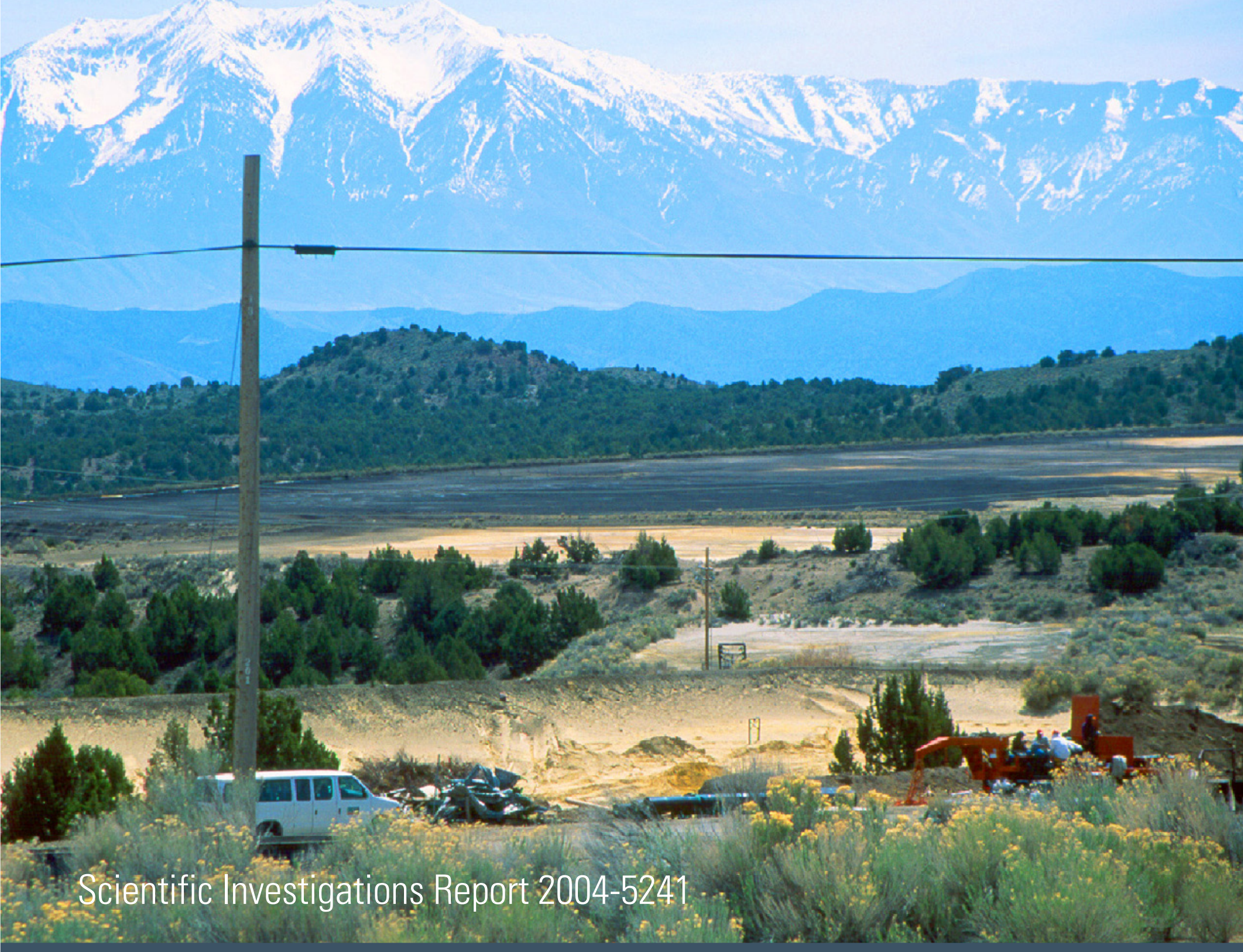




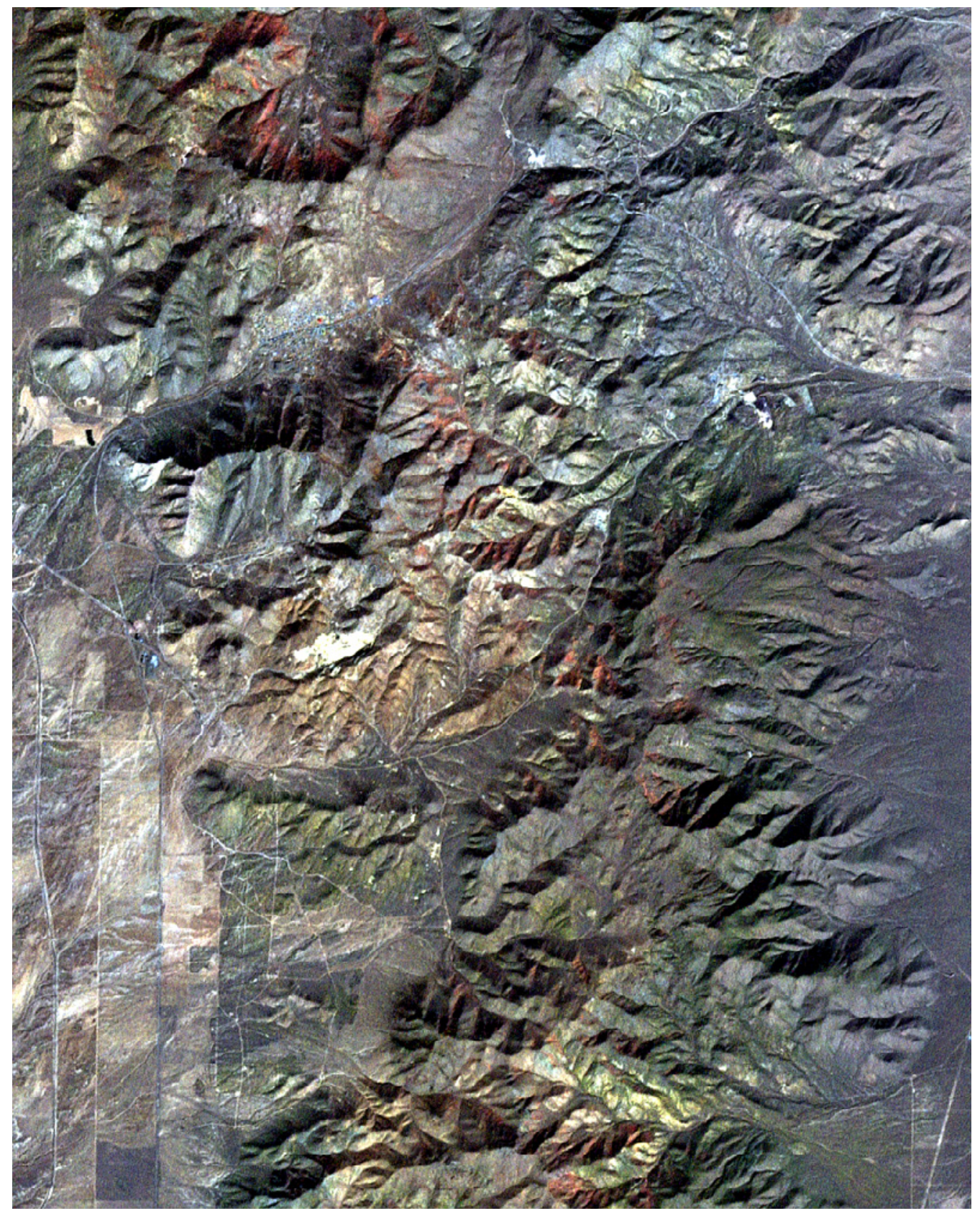

Frontispiece. Landsat 7 ETM+ true-color composite (321/RGB) centered on the Tintic mining district, Utah. Image was acquired on October 17, 1999. The data have been sharpened to $15-\mathrm{m}$ ground resolution through the use of the panchromatic band. The Dragon halloysite mine is the large white area just left of center. The brownish area surrounding the Dragon mine corresponds to altered rocks of the Silver City Monzonite stock that have been exposed by a rangeland fire. The fire occurred in June 1999 after the high-altitude AVIRIS data were acquired. The reddish tones indicate senescing deciduous vegetation in sheltered, north- and east-facing slopes and gullies.

View full-resolution file

Cover. Tailings of Burgin mine complex, East Tintic subdistrict, Utah, looking southeast toward Mount Nebo. 


\section{Remote Sensing for Environmental Site Screening and Watershed Evaluation in Utah Mine Lands-East Tintic Mountains, Oquirrh Mountains, and Tushar Mountains}

By Barnaby W. Rockwell, Robert R. McDougal, and Carol A. Gent

In cooperation with the United States Environmental Protection Agency

Scientific Investigations Report 2004-5241 


\section{U.S. Department of the Interior U.S. Environmental Protection Gale A. Norton, Secretary Agency \\ Stephen L. Johnson, Administrator \\ U.S. Geological Survey \\ P. Patrick Leahy, Acting Director}

U.S. Geological Survey, Reston, Virginia: 2005

For sale by U.S. Geological Survey, Information Services

Box 25286, Denver Federal Center

Denver, CO 80225

For more information about the USGS and its products:

Telephone: 1-888-ASK-USGS

World Wide Web: http://www.usgs.gov/

Any use of trade, product, or firm names in this publication is for descriptive purposes only and does not imply endorsement by the U.S. Government.

Although this report is in the public domain, permission must be secured from the individual copyright owners to reproduce any copyrighted materials contained within this report.

Suggested citation:

Rockwell, B.W., McDougal, R.R., and Gent, C.A., 2005, Remote sensing for environmental site screening and watershed evaluation in Utah mine lands-East Tintic Mountains, Oquirrh Mountains, and Tushar Mountains: U.S. Geological Survey Scientific Investigations Report 2004-5241, 84 p.

Authors' note: The figures presented in this report have been digitally compressed for efficient downloading during Web viewing and for ease of browsing through the CD-ROM. For most of the figures, however, there is also a fullresolution file in PDF format that can be accessed via the red link below the figure caption. Clicking on the red links will open the full-resolution files either in a new Web browser window or within Adobe Acrobat Reader. Most of the full-resolution files are in very high resolution PDF format that is suitable for printing and detailed viewing at large scales. These full-resolution maps of the Utah mine lands were the principal information source for this report and are made available for further interpretation.

To enhance ease of use, all references to figures and tables within the text are active links to those figures and tables. Click on them to quickly view the referenced object. To return to your original place in the text, click the "Previous View" button within Adobe Acrobat Reader (if viewing a PDF file). In Acrobat 7, the "Previous View" button is the green-circled, left-pointing white arrow (shortcut: Alt + Left Arrow). 


\section{Contents}

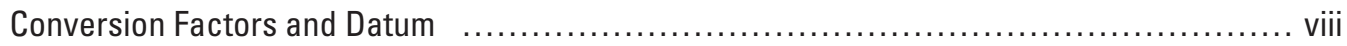

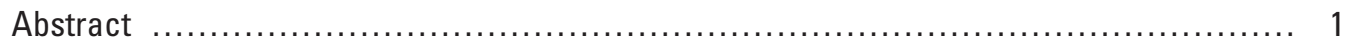

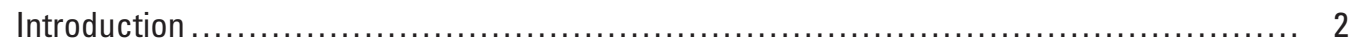

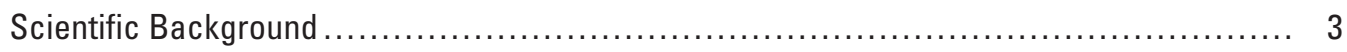

Mapping the Acid-Drainage Geochemical System Using Imaging Spectroscopy ........ 3

Other Minerals with Acid-Producing Potential in Unmined Mineralized Areas .......... 4

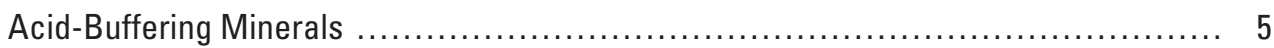

AVIRIS Data Acquisitions, Reflectance Calibration, and Georectification $\ldots \ldots \ldots \ldots \ldots \ldots \ldots \ldots$

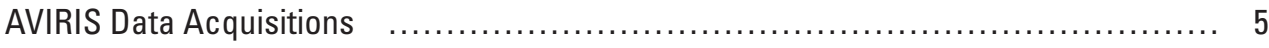

Calibration of High-Altitude AVIRIS Data ...................................... 5

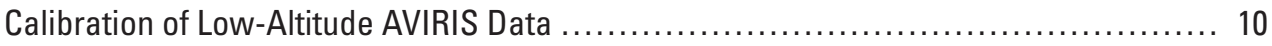

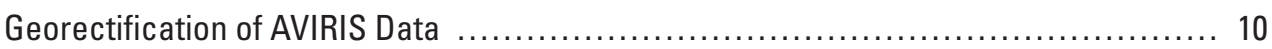

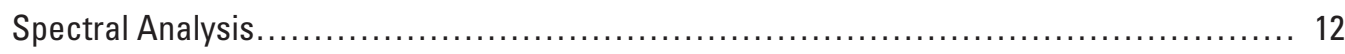

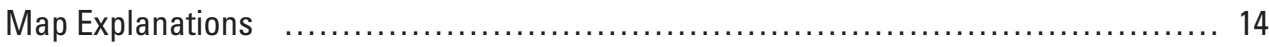

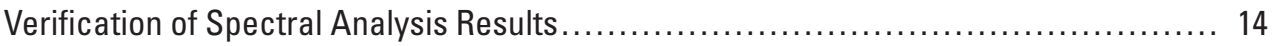

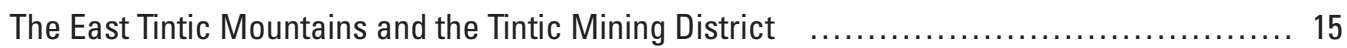

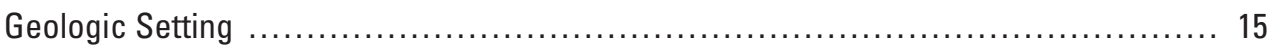

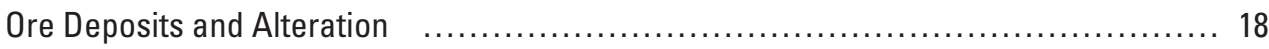

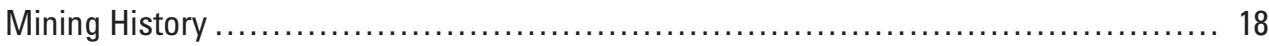

Mapping and Characterization of Mine Waste in the Tintic Mining District $\ldots \ldots \ldots \ldots \ldots$

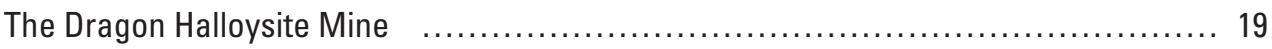

Unmined Mineralized Rocks with Acid-Producing Potential (APP) ................... 31

Rocks with Acid-Neutralizing Potential (ANP) ................................... 41

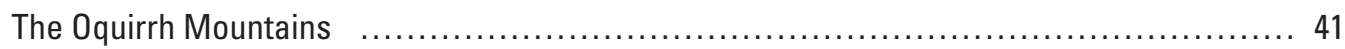

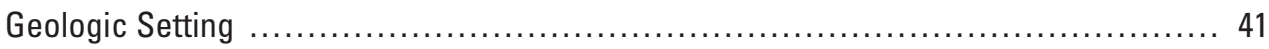

Overview of Ore Deposits and Mining History in the Mercur Area,

Camp Floyd Mining District, Southern Oquirrh Mountains .................... 41

Overview of Ore Deposits and Mining History in the Stockton Mining District .......... 43

Mapping and Characterization of Mine Waste in the Oquirrh Mountains Region ........ 43

Mercur Canyon Outwash and Manning Canyon ............................. 46

Mineral-Distribution Patterns ...................................... 46

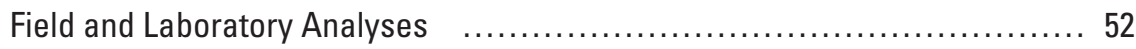

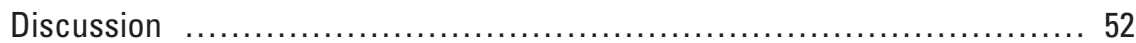

Bauer Mill Site and Tailings near Ophir Canyon ............................. 52

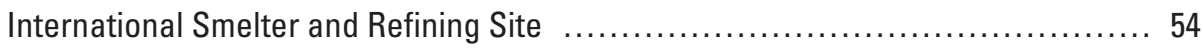

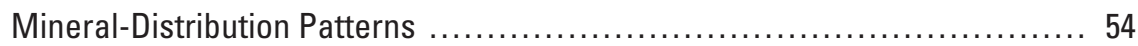

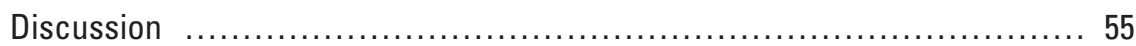

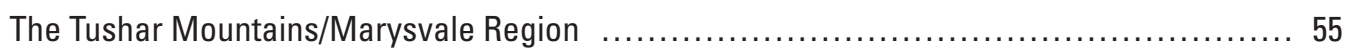

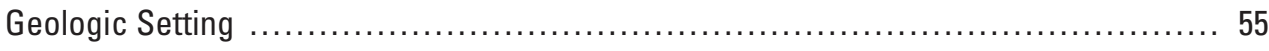

Ore Deposits and Mining History in the Eastern and Northern Tushar Mountains ........ 57

Ore Deposits and Mining History in the Antelope Range............................ 58

Mapping and Characterization of Mine Waste in the

Tushar Mountains/Marysvale Region .................................. 60

Unmined Mineralized Rocks with Acid-Producing Potential (APP) ................... 60 
Occurrences of Acid-Sulfate Alteration in the Tushar Mountains and

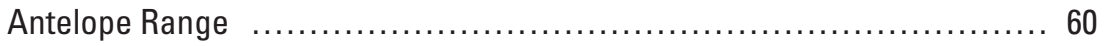

Occurrences of Jarosite in the Antelope Range and Surrounding Area ............66 61

Spectral Variations in Goethite-Bearing Rocks Observed by AVIRIS .............. 71

Acid-Sulfate Alteration on Alunite Ridge and Deer Trail Mountain ................ 72

Rocks with Acid-Neutralizing Potential (ANP) ................................... 74

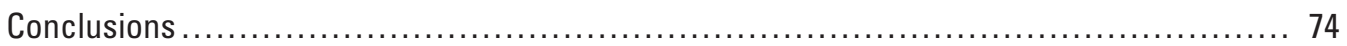

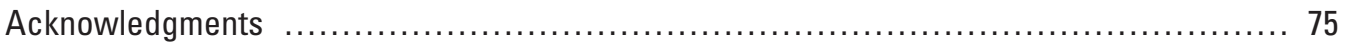

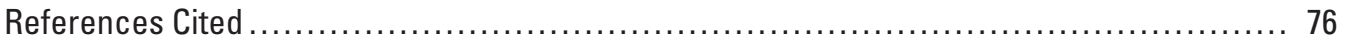

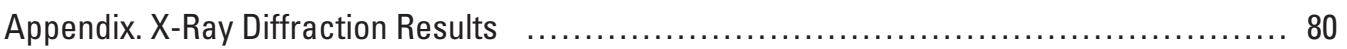

\section{Figures}

Landsat 7 ETM+ true-color composite, Tintic mining district, Utah .......... frontispiece

1. Reflectance spectra of minerals associated with acid drainage $\ldots \ldots \ldots \ldots \ldots \ldots \ldots .4$

2. Location map of East Tintic Mountains-Cedar Valley region $\ldots \ldots \ldots \ldots \ldots \ldots \ldots \ldots \ldots$

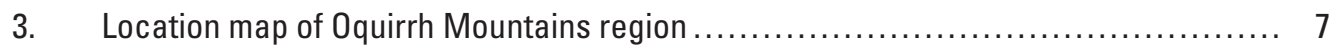

4. Location map of Tushar Mountains/Marysvale region $\ldots \ldots \ldots \ldots \ldots \ldots \ldots \ldots \ldots \ldots$

5. Location map of low-altitude AVIRIS data coverage

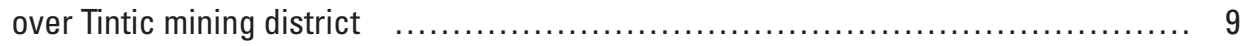

6. True-color composite image generated from low-altitude AVIRIS flightline over Silver City area and Dragon mine in the Main Tintic subdistrict .................... 11

7. True-color composite image generated from low-altitude AVIRIS flightline over

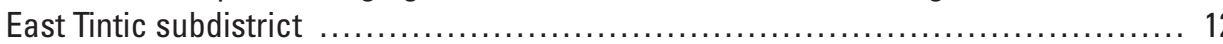

8. False-color composite image generated from low-altitude AVIRIS flightline over Big Rock Candy Mountain area of the Marysvale volcanic field .................... 13

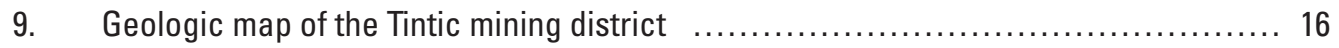

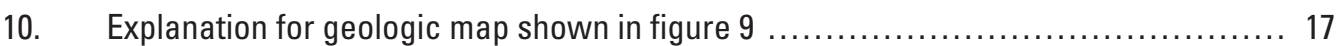

11. Map of Main Tintic subdistrict showing mines and plan views of ore bodies .......... 20

12. Map of replacement ore bodies, showing generalized compositional zonation ........ 21

13. Map of iron-bearing minerals and water in East Tintic Mountains and Tintic mining district, generated from high-altitude AVIRIS data $\quad \ldots \ldots \ldots \ldots \ldots \ldots . \ldots 22$

14. Map of clay, carbonate, sulfate, and mica minerals in East Tintic Mountains and Tintic mining district, generated from high-altitude AVIRIS data .................... 23

15. Map of iron-bearing minerals and water in Silver City-Dragon mine area, Main Tintic subdistrict, generated from low-altitude AVIRIS data .................. 24

16. Map of clay, carbonate, sulfate, and mica minerals in Silver City-Dragon mine area, Main Tintic subdistrict, generated from low-altitude AVIRIS data $\quad \ldots \ldots \ldots 25$

17. Map of iron-bearing minerals and water in East Tintic subdistrict, generated from low-altitude AVIRIS data

18. Map of clay, carbonate, sulfate, and mica minerals in East Tintic subdistrict, generated from low-altitude AVIRIS data

19. Subset of map of iron-bearing minerals and water derived from analysis of high-altitude 1998 AVIRIS data

20. Waste-rock piles with yellowish and yellow-green coatings of jarosite at the Swansea mine site near Silver City 
21. True-color composite image of Dragon halloysite mine produced from low-altitude AVIRIS data

22. Detail of map of iron-bearing minerals at the Dragon mine produced from

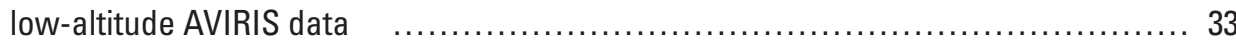

23. Pyrite-bearing waste rock in the central section of the Dragon mine ............... 34

24. Spectral minitransect across waste-rock piles in the central section of the Dragon mine 35

25. Average low-altitude AVIRIS spectra from minitransect across waste-rock piles

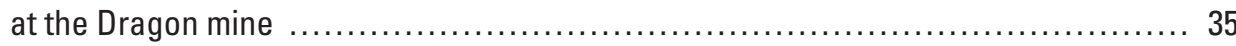

26. Landsat 7 ETM+ color composite (741/RGB) of East Tintic Mountains .............. 36

27. Subset of map of clay, carbonate, sulfate, and mica minerals derived from analysis of high-altitude 1998 AVIRIS data

28. Overlays of faults and fractures on mineral maps derived from spectral analysis of high-altitude AVIRIS data

29. Laboratory spectra of jarosites associated with unmined argillic alteration and anthropogenic, pyrite-bearing mine waste from the Dragon mine $\ldots \ldots \ldots \ldots \ldots . . \ldots 40$

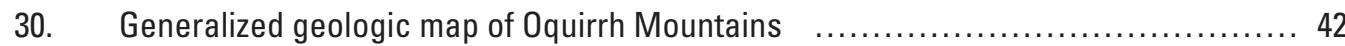

31. Map of iron-bearing minerals and water in western Oquirrh Mountains, generated from run 7 of high-altitude AVIRIS data

32. Map of clay, carbonate, sulfate, and mica minerals in western Oquirrh Mountains, generated from run 7 of high-altitude AVIRIS data

33. Map of iron-bearing minerals and water in central Oquirrh Mountains, generated from run 9 of high-altitude AVIRIS data

34. Map of clay, carbonate, sulfate, and mica minerals in central Oquirrh Mountains, generated from run 9 of high-altitude AVIRIS data

35. Map of iron-bearing minerals and water in eastern Oquirrh Mountains, generated from run 6 of high-altitude AVIRIS data

36. Map of clay, carbonate, sulfate, and mica minerals in eastern Oquirrh Mountains, generated from run 6 of high-altitude AVIRIS data

37. Landsat 7 ETM+ continuous-tone map of mineral groups and vegetation centered on southern Oquirrh Mountains

38. Tailings in the Mercur Canyon outwash, Rush Valley 49

39. Tailings at the remains of the ore-processing mill in Manning Canyon, southeastern Oquirrh Mountains

40. Tailings extending down-gradient toward the southeast from the mill site in

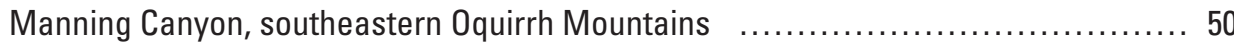

41. Open-pit clay mine in Clay Canyon, southern Oquirrh Mountains ................. 51

42. Pyrite-bearing tailings and other waste at the site of the Bauer Mill near Stockton

43. Enlargement of map of iron-bearing minerals and water over the site of the Bauer Mill near Stockton

44. Enlargement of map of clay, carbonate, sulfate, and mica minerals over the site of the Bauer Mill near Stockton

45. Enlargement of map of iron-bearing minerals and water over the International Smelter and Refining site east of Tooele

46. Enlargement of map of clay, carbonate, sulfate, and mica minerals over the International Smelter and Refining site east of Tooele 
47. Landsat 7 ETM+ continuous-tone map of mineral groups and vegetation centered on the Antelope Range several kilometers north of Marysvale

48. Map of iron-bearing minerals in central Tushar Mountains, generated from run 11 of high-altitude AVIRIS data

49. Map of clay, carbonate, sulfate, mica, and hydrous silica minerals in central Tushar Mountains, generated from run 11 of high-altitude AVIRIS data

50. Map of iron-bearing minerals and water in eastern Tushar Mountains and Antelope Range, generated from run 10 of high-altitude AVIRIS data

51. Map of clay, carbonate, sulfate, mica, and hydrous silica minerals in eastern Tushar Mountains and Antelope Range, generated from run 10 of high-altitude AVIRIS data 63

52. Map of iron-bearing minerals and water in Big Rock Candy Mountain area of Marysvale volcanic field, produced from low-altitude AVIRIS data 64

53. Map of clay, carbonate, sulfate, and mica minerals in Big Rock Candy Mountain area of Marysvale volcanic field, produced from the low-altitude AVIRIS data ........66 65

54. View of area from which uranium was extracted, looking east toward Jungfrau Peak with goethite-coated waste-rock piles in foreground 66

55. Genetic model for replacement alunite deposits, Antelope Range, Marysvale volcanic field

56. Laboratory spectra of jarosite-bearing rocks formed by hypogene and supergene processes 68

57. Spectra of natrojarosite from Big Rock Candy Mountain and the reference library $\ldots 69$

58. View of Big Rock Candy Mountain looking south along Marysvale Canyon $\ldots \ldots \ldots \ldots . . .70$

59. View of Marysvale Canyon looking north from the top of Big Rock Candy Mountain ... 70

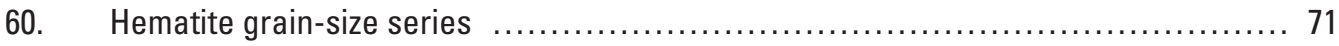

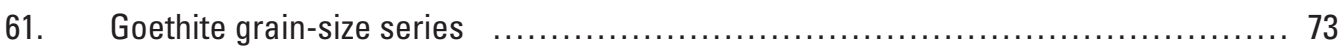




\section{Tables}

1. Ground sites used for reflectance calibration of high-altitude AVIRIS data $\ldots \ldots \ldots \ldots 10$

2. Dominant ore and gangue minerals and production figures, Tintic mining district ..... 19

3. Mine sites at which jarosite-bearing waste rock was mapped

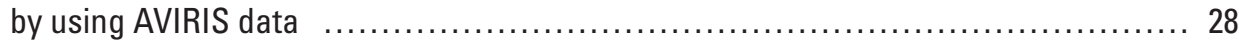

4. Total production and average ore grades of several mines near town of Eureka, Utah ........................................................ 31

\section{Appendix Tables}

1. XRD analysis results - Tintic mining district, Utah 80

2. XRD analysis results and field XRF data-Mercur outwash, southwestern

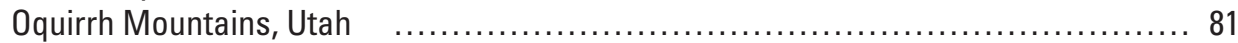

3. XRD analysis results_-Tushar Mountains/Marysvale region, Utah $\ldots \ldots \ldots \ldots \ldots \ldots \ldots 82$ 


\section{Conversion Factors and Datum}

\begin{tabular}{lll}
\hline Multiply & By & To obtain \\
\hline & Mass & \\
ounce, avoirdupois $(\mathrm{oz})$ & 28.35 & gram $(\mathrm{g})$ \\
ton, short $(2,000 \mathrm{lb})$ & 0.9072 & megagram $(\mathrm{Mg})$ \\
\hline
\end{tabular}

Metric ton (t) as a name for megagram $(\mathrm{Mg}$ ) should be restricted to commercial usage, and no prefixes should be used with it.

\begin{tabular}{lll}
\hline Multiply & By & To obtain \\
\hline & Length & \\
centimeter $(\mathrm{cm})$ & 0.3937 & inch (in.) \\
meter $(\mathrm{m})$ & 3.281 & foot (ft) \\
kilometer $(\mathrm{km})$ & 0.6214 & mile (mi) \\
\hline
\end{tabular}

Horizontal coordinate information is referenced to the NAD27 horizontal datum.

Temperature in degrees Celsius $\left({ }^{\circ} \mathrm{C}\right)$ may be converted to degrees Fahrenheit $\left({ }^{\circ} \mathrm{F}\right)$ as follows: ${ }^{\circ} \mathrm{F}=\left(1.8 \times{ }^{\circ} \mathrm{C}\right)+32$.

Temperature in degrees Fahrenheit $\left({ }^{\circ} \mathrm{F}\right)$ may be converted to degrees Celsius $\left({ }^{\circ} \mathrm{C}\right)$ as follows: ${ }^{\circ} \mathrm{C}=\left({ }^{\circ} \mathrm{F}-32\right) / 1.8$. 


\title{
Remote Sensing for Environmental Site Screening and Watershed Evaluation in Utah Mine Lands-East Tintic Mountains, Oquirrh Mountains, and Tushar Mountains
}

\author{
By Barnaby W. Rockwell, Robert R. McDougal, and Carol A. Gent
}

\section{Abstract}

Imaging spectroscopy - a powerful remote-sensing tool for mapping subtle variations in the composition of minerals, vegetation, and man-made materials on the Earth's surfacewas applied in support of environmental assessments and watershed evaluations in several mining districts in the State of Utah. Three areas were studied through the use of Landsat 7 ETM+ and Airborne Visible/Infrared Imaging Spectrometer (AVIRIS) data: (1) the Tintic mining district in the East Tintic Mountains southwest of Provo, (2) the Camp Floyd mining district (including the Mercur mine) and the Stockton (or Rush Valley) mining district in the Oquirrh Mountains south of the Great Salt Lake, and (3) the Tushar Mountains and Antelope Range near Marysvale.

The Landsat 7 ETM+ data were used for initial site screening and the planning of AVIRIS surveys. The AVIRIS data were analyzed to create spectrally defined maps of surface minerals with special emphasis on locating and characterizing rocks and soils with acid-producing potential (APP) and acidneutralizing potential (ANP). These maps were used by the United States Environmental Protection Agency (USEPA) for three primary purposes: (1) to identify unmined and anthropogenic sources of acid generation in the form of iron sulfide and (or) ferric iron sulfate-bearing minerals such as jarosite and copiapite; (2) to seek evidence for downstream or downwind movement of minerals associated with acid generation, mine waste, and (or) tailings from mines, mill sites, and zones of unmined hydrothermally altered rocks; and (3) to identify carbonate and other acid-buffering minerals that neutralize acidic, potentially metal bearing, solutions and thus mitigate potential environmental effects of acid generation.

Calibrated AVIRIS surface-reflectance data were spectrally analyzed to identify and map selected surface materials. Two maps were produced from each flightline of AVIRIS data: a map of iron-bearing minerals and water having absorption features in the spectral region from $0.35 \mu \mathrm{m}$ to $1.35 \mu \mathrm{m}$ and a map of minerals (including clays, sulfates, micas, and carbonates) having absorptions in the spectral region from $1.45 \mu \mathrm{m}$ to 2.51 $\mu \mathrm{m}$. Several methods were used to verify the AVIRIS mapping results, including field checking of selected locations with a portable spectrometer, visual inspection of the AVIRIS reflectance spectra, and X-ray diffraction (XRD) analysis of field samples.

The maps of iron-bearing minerals derived from analysis of the visible (VIS) and near-infrared (NIR) regions of the electromagnetic spectrum were shown to be more consistently reliable in indicating the presence of jarosite than were the maps generated from analysis of the short-wave infrared (SWIR) region. When present in abundance, phyllosilicate minerals tend to dominate the SWIR and mask the spectral features of jarosite in that wavelength region. The crystal field absorptions of jarosite in the VIS and NIR spectral regions will commonly be present regardless of whether the $\mathrm{Fe}-\mathrm{OH}$ absorption feature near $2.27 \mu \mathrm{m}$ can be detected. For this reason, the VIS and NIR were preferable to the SWIR for the remote spectroscopic identification of jarosite (and other iron-bearing minerals).

Large exposures of unmined hydrothermally altered rocks occur throughout the three study areas. These rocks commonly contain sulfide or sulfate minerals that produce sulfuric acid upon subaerial oxidation. The acid may be introduced into local surface and ground water and thus lower the baseline (that is, the premining) $\mathrm{pH}$ for a watershed.

The three study areas also have widespread exposures of rocks with acid-neutralizing potential. Lithologies containing carbonates and (or) other acid-buffering minerals - such as sedimentary limestones and dolomites and propylitically altered igneous rocks - were mapped with the AVIRIS data throughout the Oquirrh and East Tintic Mountains and locally in the Antelope Range and Tushar Mountains.

Because elevated levels of various heavy metals in local soils and tap water have been identified by previous USEPA studies, parts of the town of Eureka in the Main Tintic subdistrict of the Tintic mining district are being proposed as a Superfund site. Although many piles of mine-waste rocks in the Tintic mining district contain oxidizing sulfide minerals that are important point sources of sulfuric acid and heavy metals, little spectral evidence was found for downstream or downwind movement of materials from these piles. In most cases, acid-producing waste is confined to mine sites, largely because of low amounts of annual precipitation. However, 
further study of the waste rock and local hydrology at the Chief No. 1 and Centennial/Eureka mines is warranted because of their proximity to the town of Eureka. The tailings and waste rock near the Burgin mine in the East Tintic subdistrict of the Tintic mining district are the largest spectrally identified exposures of jarositic rocks in the study area. The Burgin mine area, although not as near a town, is the site of a proposed municipal water source. Few exposures of carbonate-bearing rocks exist downstream from most mine sites in the Tintic district. Therefore, in general, relatively little natural acidneutralizing potential exists that could buffer acidic solutions emanating from waste-rock piles and tailings in the district.

In the Oquirrh Mountains, the International Smelter and Refining site, Bauer Mill site, Mercur Canyon outwash, and Manning Canyon tailings are of particular interest because of the presence of elevated levels of heavy metals identified by previous USEPA and United States Bureau of Land Management (USBLM) studies. Several of these areas have been proposed as Superfund sites. Elevated levels of arsenic, mercury, iron, and other metals were identified in mine tailings from the Mercur Canyon outwash and Manning Canyon by field X-ray fluorescence (XRF) studies. The AVIRIS data were used to map areal extents of these deposits of metal-bearing tailings on the basis of the strong spectral signatures of goethite, kaolinite, and muscovite (or illite) that are characteristic of the tailings. At the Bauer Mill site near Stockton, pyrite-rich tailings surrounded by a subconcentric zonation pattern of iron-bearing sulfates, hydroxides, and oxides were identified through analysis of the AVIRIS data and verified in the field. This zonation pattern is attributed to the subaerial oxidation of the pyrite-rich tailings. The areal distribution pattern of iron-bearing minerals at the Bauer Mill site suggests that some of the tailings material is being transported northward from the mill site by prevailing southerly winds. In contrast, the possible occurrence of minerals associated with elevated metal levels down-gradient from the International Smelter and Refining site could not be mapped by using the AVIRIS data because of vegetation cover.

In the Antelope Range north of Marysvale, unmined pyrite-bearing rocks having high acid-producing potential are found in propylitically altered feeder zones of convective hydrothermal cells formed during Miocene time. These feeder zones are exposed along the Sevier River in Marysvale Canyon at Big Rock Candy Mountain, immediately across the river within the Big Star cell, and surrounding the White Horse mine northeast of the town of Marysvale. Sulfate-bearing sediment being shed from the steep and exposed eastern and northern slopes of Big Rock Candy Mountain was mapped with the AVIRIS data. Little evidence was found of downstream movement of jarositic sediments from rocks associated with the other hydrothermal cells in the Antelope Range. Pyrite-poor hypogene jarosite co-occurring with replacement alunite is found above the feeder zones of several of the cells, most notably in the Yellow Jacket cell. Exposures of jarosite derived from pyrite oxidation are also found in the eastern Tushar Mountains in the vicinities of Alunite Ridge and Deer Trail
Mountain along with abundant vein alunite. Alunitic sediment has been shed eastward into the Sevier River Valley from the Alunite Ridge-Deer Trail Mountain area. Abundant carbonatebearing rocks exposed near the base of Deer Trail Mountain may serve to buffer acidic solutions derived from the large deposits of alunite higher on the mountain. No significant occurrences of mine waste or mill tailings containing oxidizing sulfide minerals were positively identified through the use of the AVIRIS data in the Marysvale region. This study did not address possible radiological hazards associated with mine-waste rock in the areas from which uranium was extracted.

Analysis of Landsat 7 ETM+ data can provide a very cost-effective screening tool for identifying mineralized and (or) mining-affected areas and guiding the planning of lowaltitude imaging spectrometer surveys or field investigations. Then, when coupled with a geological understanding of a study area, the interpretation of mineral maps derived from imaging spectroscopy data can be an effective means of (1) evaluating potential environmental impacts associated with hydrothermally altered rocks and mine waste on a watershed or regional scale and (2) focusing field-sampling and remediation programs.

\section{Introduction}

This report is a summary of the results obtained from analysis and interpretation of spectroscopic imagery collected by the Airborne Visible/Infrared Imaging Spectrometer (AVIRIS) over several mining districts in Utah. The specific study areas described in this report are the East Tintic Mountains in Utah and Juab Counties; the Oquirrh Mountains in Tooele, Utah, and Salt Lake Counties; and the Tushar Mountains and Antelope Range near Marysvale in Sevier and Piute Counties. Most mining activity in these areas has ceased, although there are some important exceptions, including the Bingham Canyon porphyry copper mine in the Oquirrh Mountains, the Trixie mine (gold, silver, copper) in the East Tintic subdistrict of the Tintic mining district, and the (new) Deer Trail mine (gold, silver, zinc) on the eastern flank of the Tushar Mountains.

This geophysical and mineralogical research was undertaken as a part of the United States Environmental Protection Agency (USEPA) and U.S. Geological Survey (USGS) Utah Abandoned Mine Lands (AML) Imaging Spectroscopy Project (U.S. Environmental Protection Agency and U.S. Geological Survey, 2002). An index map showing the study areas for this project is available on the project Web site (http://speclab.cr.usgs.gov/earth.studies/Utah-1/utahproj_large.jpg). The project had three primary goals:

- to remotely identify and map natural and anthropogenic sources of acid generation in and around several historic mining districts in Utah;

- to seek evidence for downstream or downwind transport of minerals associated with acid generation from mine sites and zones of unmined, altered rock; and 
- to identify and map carbonates and other acid-buffering minerals that neutralize acidic, potentially metal bearing solutions, thus mitigating their environmental effects.

Remotely sensed image data were used to screen and evaluate watersheds containing multiple sources of mining-related heavy metals because ground surveys using traditional methods of multimedia sampling and analysis are costly and time consuming. The geologic analysis of spectroscopic image data such as those acquired by AVIRIS enables the detection of specific materials and mixtures of materials on the land surface based on quantitative comparisons of spectral absorption features in the image data to libraries of standard reference spectra of minerals, water, vegetation, and man-made materials. Such detailed mapping allows an evaluation of the critical geochemical regimes and processes in an area, thus providing an objective, scientific means of prioritizing potential environmental hazards for the purposes of streamlining and focusing subsequent field-sampling and remediation programs.

\section{Scientific Background}

\section{Mapping the Acid-Drainage Geochemical System Using Imaging Spectroscopy}

The iron sulfide mineral pyrite $\left(\mathrm{FeS}_{2}\right)$ is a common gangue, or waste, mineral in precious and base metal deposits such as those in the mining districts studied in the Utah AML project. Because pyrite contains sulfur and is commonly unstable in moist, subaerial conditions, the mineral plays a key role in determining future geochemical regimes when it is exposed either by erosion or by mining. During mining operations, broken-up waste rock containing pyrite, carbonate minerals (for example, calcite and dolomite), and (or) phyllosilicate minerals (for example, clays and micas) associated with hydrothermal alteration was commonly dumped near the shafts, adits, and open pits of the mines. At ore-processing mills, slurries of tailings material containing pyrite and other gangue minerals were released into impoundments or directly into drainages. Through time, the pyrite will oxidize in the presence of atmospheric oxygen and water to form sulfuric acid $\left(\mathrm{H}_{2} \mathrm{SO}_{4}\right)$ and various ferric and (or) ferrous iron sulfate-hydrate minerals including copiapite $\left(\mathrm{Fe}^{2+} \mathrm{Fe}_{4}^{3+}\left(\mathrm{SO}_{4}\right)_{6}(\mathrm{OH})_{2} \cdot 2 \mathrm{H}_{2} \mathrm{O}\right)$, and melanterite $\left(\mathrm{Fe}^{2+} \mathrm{SO}_{4} \cdot 7 \mathrm{H}_{2} \mathrm{O}\right)$. As a part of the reaction process, thin coatings of sulfate salts such as copiapite may be precipitated on waste-rock surfaces as water from rain events evaporates. With time, most of the pyrite in the waste rock will oxidize, leaving behind coatings of fine-grained jarosite $\left(\left(\mathrm{K}, \mathrm{Na}, \mathrm{H}_{3} \mathrm{O}\right) \mathrm{Fe}_{3}^{3+}\left(\mathrm{SO}_{4}\right)_{2}(\mathrm{OH})_{6}\right)$ that are more stable and less soluble than the hydrated iron sulfate salts that precipitate early in the process. These coatings may in turn break down to the metastable mineral ferrihydrite (approximately $5 \mathrm{Fe}^{3+}{ }_{2} \mathrm{O}_{3} \cdot 9 \mathrm{H}_{2} \mathrm{O}$ ), then to the ferric iron hydroxide mineral goethite $\left(\alpha-\mathrm{Fe}^{3+} \mathrm{O}(\mathrm{OH})\right)$, and, with additional time, possibly to the ferric iron oxide mineral hematite $\left(\mathrm{Fe}_{2} \mathrm{O}_{3}\right)$ (Swayze and others, 2000). In natural and anthropogenic exposures of jarosite formed from the oxidation of pyrite, a zoning pattern of iron-bearing minerals is commonly observed that reflects the $\mathrm{pH}$ of the waters from which the minerals precipitated (Swayze and others, 2000; Rockwell and others, 1999, 2000). This pattern consists of a central core of unaltered pyrite and (or) copiapite formed under low-pH conditions that grades outward into subconcentric and commonly discontinuous zones of jarosite, jarosite + goethite, goethite, and hematite formed under progressively more neutral $\mathrm{pH}$ conditions. The metastable secondary mineral schwertmannite $\left(\mathrm{Fe}^{3+}{ }_{16} \mathrm{O}_{16}(\mathrm{OH})_{12}\left(\mathrm{SO}_{4}\right)_{2}\right)$ may also form in environments affected by acid drainage from undisturbed rocks, mine waste, and tailings (Ferris and others, 1989; Bigham and others, 1992; Desborough and others, 2000).

The sulfuric acid-bearing solutions generated by the oxidizing reactions can infiltrate downward through the waste-rock pile. The weathering process can also produce clay minerals such as smectites (for example, montmorillonite, $\left.(\mathrm{Na}, \mathrm{Ca})_{0.33}(\mathrm{Al}, \mathrm{Mg})_{2} \mathrm{Si}_{4} \mathrm{O}_{10}(\mathrm{OH})_{2} \cdot n \mathrm{H}_{2} \mathrm{O}\right)$ and kaolinite $\left(\mathrm{Al}_{2} \mathrm{Si}_{2} \mathrm{O}_{5}(\mathrm{OH})_{4}\right)$ as alteration products of feldspars and micas in the waste rock; kaolinite forms under the most acidic conditions. If $\mathrm{Ca}$ concentrations in the acidic solutions are sufficiently high, gypsum $\left(\mathrm{CaSO}_{4} \cdot 2 \mathrm{H}_{2} \mathrm{O}\right)$ may precipitate. The acidic solutions can also mobilize heavy metals (lead, cadmium, zinc, arsenic, etc.) present in the waste rock and potentially transport them into ground and surface water. If present in sufficient concentrations, these heavy metals can pose a health hazard, and they have been found to preferentially adsorb onto amorphous iron hydroxide minerals contained within mine waste in near-neutral $\mathrm{pH}$ environments where residence times can be long (Bowell, 1994).

Imaging spectroscopy has been used since the mid 1990s to map surface minerals in abandoned mine lands for the purposes of environmental site characterization (Farrand and Harsanyi, 1997; Smith and others, 1998; Swayze and others, 2000; King and others, 2000; Dalton and others, 2000). As copiapite, jarosite, goethite, and hematite are characterized by distinct and diagnostic spectral absorption features in the region of the electromagnetic spectrum measured by AVIRIS and other imaging spectrometers (fig. 1) (Crowley and others, 2003), these minerals can be remotely identified and differentiated with a high degree of accuracy by using imaging spectroscopy. In contrast, pyrite is difficult to detect through the use of remote spectroscopic mapping techniques because of its low overall albedo, weak (saturated) absorption features, and frequent masking by coatings of secondary iron sulfate minerals. Pyrite in very high concentrations, however, has been successfully identified and mapped by using AVIRIS data: both the Leadville, Colorado, mining district (Swayze and others, 2000) and the Bauer Mill site near Stockton, Utah (this report), have sufficient waste-rock pyrite to be identified and mapped by AVIRIS. In these cases, the mapped pyrite was surrounded by pixels in which jarosite was identified. Jarosite is thus an important indicator of the presence of rocks bearing pyrite, possibly other sulfide minerals such as chalcopyrite $\left(\mathrm{CuFeS}_{2}\right)$, and (or) other sulfate minerals that are sources for 
the generation of acidic solutions. Copiapite is also an important indicator of sulfide minerals that can be reliably mapped with imaging spectroscopy data, but is highly soluble and is therefore less common than jarosite. Other highly soluble, sulfate-bearing salts such as alunogen $\left(\mathrm{Al}_{2}\left(\mathrm{SO}_{4}\right)_{3} \cdot 17 \mathrm{H}_{2} \mathrm{O}\right)$ and epsomite $\left(\mathrm{MgSO}_{4} \cdot 7 \mathrm{H}_{2} \mathrm{O}\right)$ are also detectable with AVIRIS data, although the lack of narrow diagnostic absorption features in the spectra of these minerals makes remote detection less accurate. These soluble salts may be precipitated as thin, temporary crusts on exposed, pyrite-bearing rock after rain events (Cunningham and others, 2005). As the crusts dry, they can change in color (from yellowish orange to gray or white), suggesting possible mineralogic changes that could be identified and monitored by using spectroscopic data. Although ferrihydrite also has diagnostic electronic absorption features conducive to spectral identification and has been found to occur abundantly in acid-mine-drainage environments (Ferris and others, 1989), it has yet to be definitively identified through the use of imaging spectrometer data because of the apparent spectral dominance of jarosite, goethite, and hematite at the pixel scale and (or) the tendency of ferrihydrite to dissolve and reprecipitate as goethite (Bigham and others, 1992). Schwertmannite is stable at the Earth's surface only in low-pH

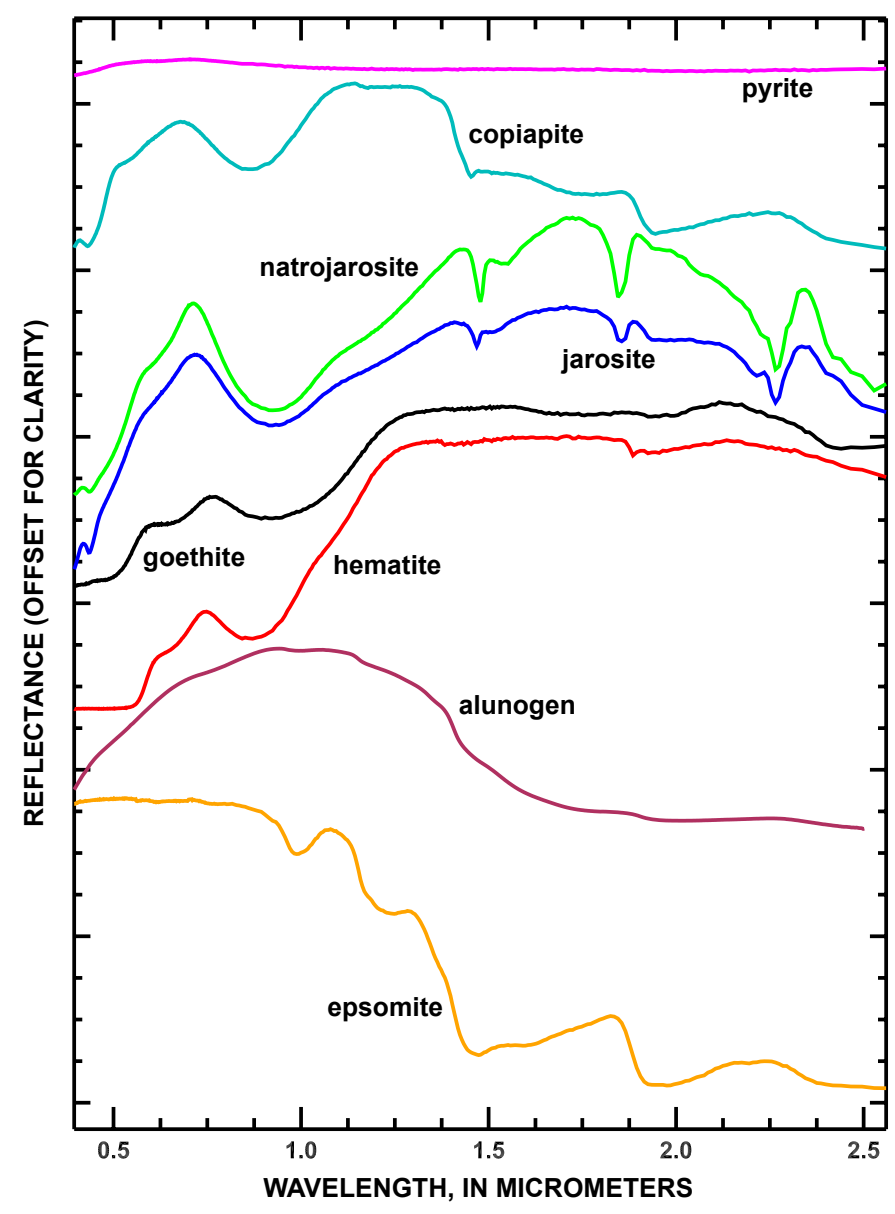

Figure 1. Reflectance spectra of minerals associated with acid drainage. and (or) aqueous environments, yet was spectrally identified in ferricretes associated with acid rock drainage in the Animas River watershed of the San Juan Mountains of Colorado (Dalton and others, 2000; Desborough and others, 2000).

The just-described background indicates that sitecharacterization plans developed on the basis of maps derived from remote-sensing surveys should focus subsequent field-sampling efforts on areas in which spectra signifying pyrite-, copiapite-, schwertmannite-, or jarosite-bearing mineral assemblages were identified, as it is likely that rocks in these areas contain the highest concentrations of acid-producing sulfide or sulfate minerals. However, it should be noted that goethite coatings on weathered rocks on the surface may mask abundant pyrite occurring in underlying rocks. On the basis of field studies and an understanding of the geochemical regimes discussed above, however, it can be generally assumed that there will be less pyrite at and near the surface in areas where goethite is prevalent than in areas where jarosite is the spectrally dominant mineral and, therefore, that surface runoff from goethite-coated areas will be of more neutral $\mathrm{pH}$ than that derived from jarositic areas.

\section{Other Minerals with Acid-Producing Potential in Unmined Mineralized Areas}

Acid-producing minerals also occur on the Earth's surface in the natural environment, usually in rocks that have been altered and mineralized by hydrothermal solutions. Most sulfide and hydrous iron sulfate minerals have some acid-producing potential (APP), and the most commonly occurring of these can be ordered from high to low APP as follows: pyrite, copiapite, schwertmannite, and fine-grained secondary jarosite formed via pyrite oxidation. The APP of such jarosite is discussed by Desborough and others (1999). Alunite $\left((\mathrm{Na}, \mathrm{K}) \mathrm{Al}_{3}\left(\mathrm{SO}_{4}\right)_{2}(\mathrm{OH})_{6}\right)$ is a common mineral formed by acid-sulfate hydrothermal alteration and is found in abundance in the Tintic and Marysvale districts in Utah, the Silverton and Lake City calderas and the Summitville deposit in Colorado, and in the Goldfield and Cuprite districts in Nevada, among many others. Alunite (Rye and others, 1992) and some spectrally identifiable clay minerals, such as dickite $\left(\mathrm{Al}_{2} \mathrm{Si}_{2} \mathrm{O}_{5}(\mathrm{OH})_{4}\right)$ and pyrophyllite $\left(\mathrm{Al}_{2} \mathrm{Si}_{4} \mathrm{O}_{10}(\mathrm{OH})_{2}\right)$, commonly occur with pyrite in magmatic hydrothermal acid-sulfate systems. Therefore, although these minerals have never been associated with acid generation themselves, they can also be regarded as indicators of sources of potentially strong acid generation.

Not all jarosite is associated with the presence of pyrite. Primary hypogene jarosite can form in steam-heated acid-sulfate hydrothermal systems such as those associated with the Miocene replacement alunite deposits in the Marysvale volcanic field, Utah (Cunningham and others, 1984; Rye and Alpers, 1997; Rockwell and others, 2000). Such jarosite formed when rising, acidic, sulfate-rich solutions became depleted in aluminum relative to ferric iron. As the $\mathrm{H}_{2} \mathrm{~S}$-bearing solutions rose, boiled, 
and became oxygenated at and just below the paleo-ground-water table, sulfuric acid was produced that leached many of the original constituent minerals of the host rock, and replacement alunite was deposited. As the solutions continued to rise above the paleo-ground-water table, abundant atmospheric oxygen neutralized the rock's buffering capacity, resulting in a local decrease in fluid $\mathrm{pH}$ (Stoffregen, 1993). The more oxygenated and acidic conditions promoted the replacement of aluminum by ferric iron in the sulfate mineral structure and, consequently, the deposition of jarosite. This hypogene process produces rocks characterized by co-occurring alunite and jarosite with little or no pyrite. Jarosite formed by such hypogene processes is typically coarse grained and has low APP, if any. Gold and silver deposits can form in similar steam-heated, acid-sulfate epithermal systems associated with geothermal fields (Ebert and Rye, 1997). Such deposits are "environmentally friendly" to mine when compared to high-sulfidation deposits such as those of the Tintic, Utah, Summitville, Colorado, and Goldfield, Nevada, districts because of the relative scarcity of pyrite.

When performing watershed-based environmental evaluations, researchers should consider that ground and surface runoff from unmined, but hydrothermally altered rocks might have a lower $\mathrm{pH}$ than runoff from unaltered rocks and that such low-pH runoff could effectively lower the premining $\mathrm{pH}$ baseline of a watershed. However, it can be generally assumed that pyrite-bearing waste-rock piles at mine sites and tailings near mill sites will have significantly higher APP than similarly sized exposures of naturally occurring, sulfur-bearing altered rock because (1) the acid-producing minerals in waste-rock piles and tailings are commonly in chemical disequilibrium with atmospheric conditions, (2) the surface area of sulfur-bearing minerals available for oxidation is increased because of the generally small grain size of the blasted or processed waste rock, and (3) the waste-rock piles are highly permeable, allowing for rapid penetration of oxidizing precipitation.

\section{Acid-Buffering Minerals}

The carbonate minerals calcite $\left(\mathrm{CaCO}_{3}\right)$ and dolomite $\left(\mathrm{CaMg}\left(\mathrm{CO}_{3}\right)_{2}\right)$ buffer acidic solutions on contact, causing an increase in fluid $\mathrm{pH}$ and the precipitation of some dissolved metals. "Free-hydroxyl" minerals such as chlorite $\left((\mathrm{Mg}, \mathrm{Al}, \mathrm{Fe})_{12}\left[(\mathrm{Si}, \mathrm{Al})_{8} \mathrm{O}_{20}\right](\mathrm{OH})_{16}\right)$ and the sorosilicate mineral epidote $\left(\mathrm{Ca}_{2}\left(\mathrm{Al}, \mathrm{Fe}^{3+}\right)_{3}\left(\mathrm{SiO}_{4}\right)_{3}(\mathrm{OH})\right)$ have more limited capacities for acid neutralization. The buffering capacity, or acid-neutralizing potential (ANP), of chlorite has been estimated to be an order of magnitude weaker than that of calcite (Desborough and others, 1998). If rocks bearing these minerals are located downstream from sources of acid generation, they can provide some buffering capacity.

\section{AVIRIS Data Acquisitions, Reflectance Calibration, and Georectification}

\section{AVIRIS Data Acquisitions}

Spectroscopic image data covering the East Tintic Mountains (fig. 2), the Oquirrh Mountains (fig. 3), and the Tushar Mountains/ Marysvale region (fig. 4) of Utah were acquired on August 5, 1998, by the AVIRIS sensor from the high-altitude National Aeronautics and Space Administration (NASA) ER-2 aircraft flying at an altitude of $\approx 20 \mathrm{~km}$ (Vane, 1987). These data have a GIFOV (ground instantaneous field of view), or ground spatial resolution, of $\approx 17$ $\mathrm{m} /$ pixel. Nongeorectified quicklook images of the high-altitude AVIRIS flightlines, or "runs," are accessible from the online quicklook index of 1998 data (http://aviris.jpl.nasa.gov/ql/list98.html) on the NASA Jet Propulsion Laboratory (JPL) AVIRIS Web site. The satellite-borne Landsat 7 ETM+ sensor acquired multispectral image data of these areas on October 17, 1999. The Landsat 7 data have a ground resolution of $\approx 30 \mathrm{~m} /$ pixel.

In 1999, a second phase of the project focused more detailed mapping on intensely mined and (or) mineralized areas identified by the high-altitude 1998 survey. On October 17-19, 1999, additional flightlines (17 total) of low-altitude AVIRIS data were acquired over selected parts of the study areas. These data were acquired from a Twin Otter aircraft flying at $\approx 5.33 \mathrm{~km}$ altitude and have a ground resolution of 2-3 m/pixel. Georectified quicklook images of these low-altitude AVIRIS flightlines are accessible from the online quicklook index of 1999 low-altitude AVIRIS data (http://aviris.jpl.nasa. gov/ql/listla99.html) on the NASA JPL AVIRIS Web site. Results obtained from the analysis of three of these flightlines of low-altitude AVIRIS data are presented in this report.

Figure 4 shows the location of the flightline covering the Big Rock Candy Mountain area near Marysvale, and figure 5 shows the locations of the two flightlines covering the Tintic mining district. Results from analysis of the Big Rock Candy Mountain flightline are also discussed by Cunningham and others (2005).

\section{Calibration of High-Altitude AVIRIS Data}

The high-altitude AVIRIS data are calibrated to reflectance by using a two-step process (Rockwell and others, 2002; King and others, 2000). In the first step, the data are corrected by using an algorithm (ATREM, Gao and Goetz, 1990; Gao and others, 1992) that estimates the amount of atmospheric water vapor in the spectrum of each pixel independently, as compared with an atmospheric model. The algorithm uses this information on a pixel-by-pixel basis to reduce the effects of absorptions caused by atmospheric water vapor. This step also includes characterizing and removing the effects of Rayleigh and aerosol scattering in the atmosphere (path radiance) and a correction for the solar spectral response relative to wavelength. The second step requires the on-site spectral characterization of a ground-calibration site 


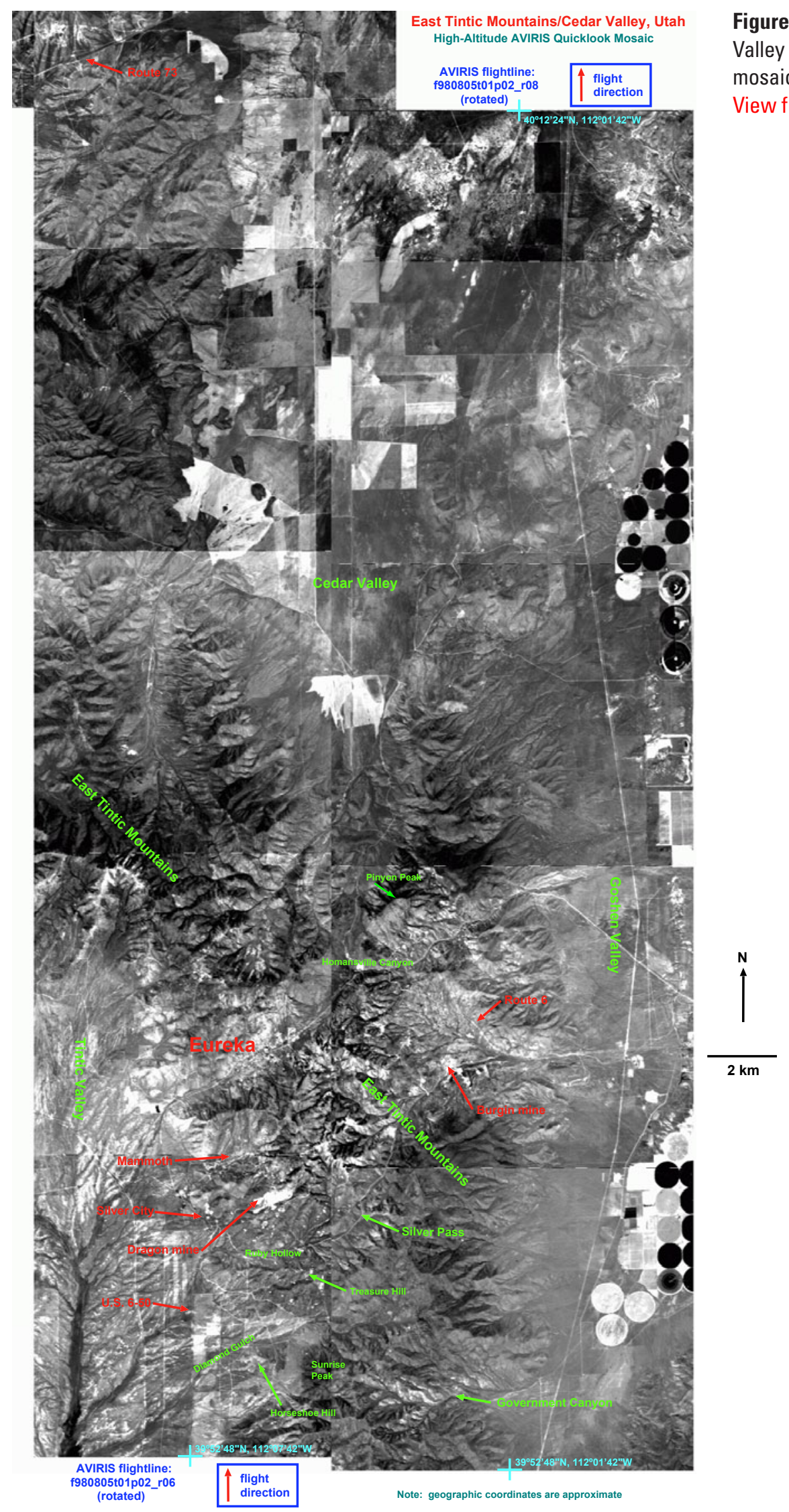

Figure 2. Location map of East Tintic Mountains-Cedar Valley region, Utah. Background is an uncontrolled mosaic of high-altitude AVIRIS quicklook images. View full-resolution file 


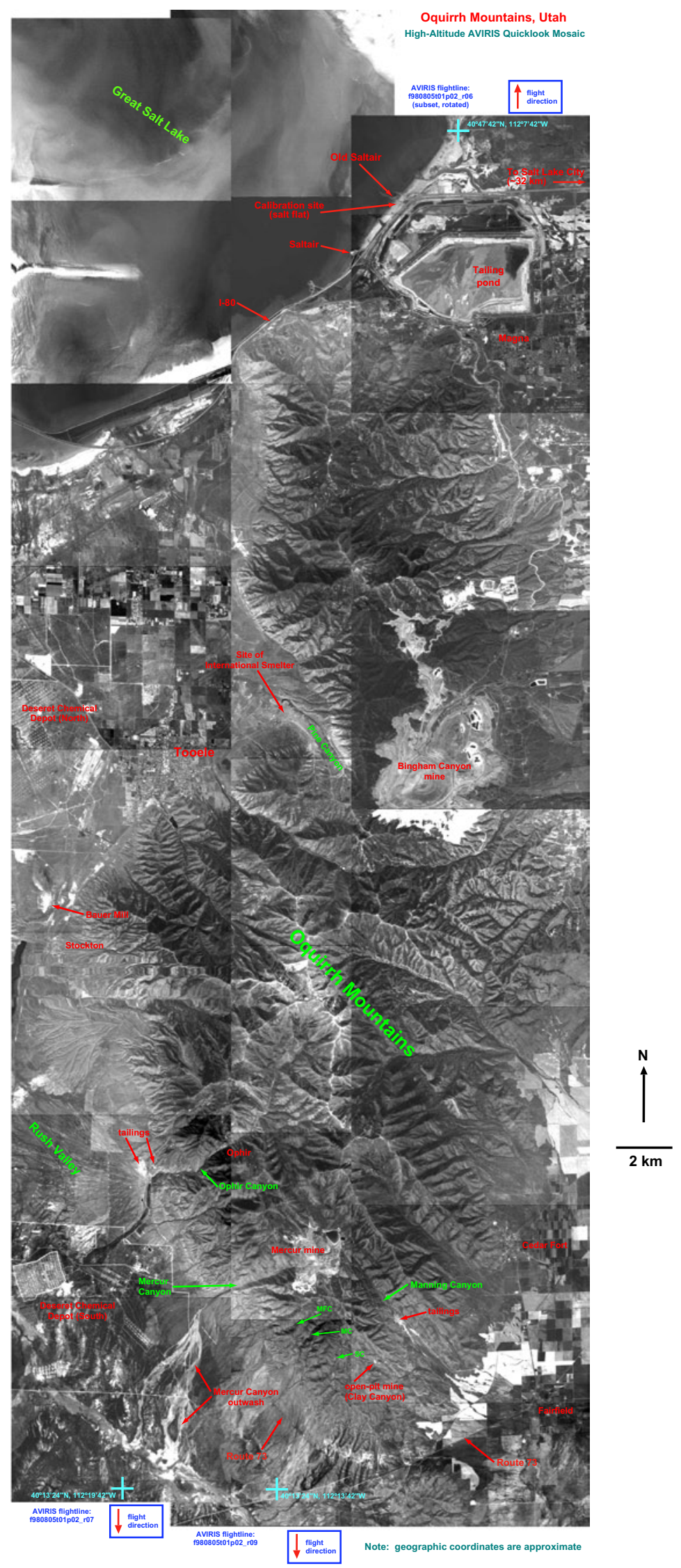

Figure 3. Location map of Oquirrh Mountains region, Utah. Background is an uncontrolled mosaic of high-altitude AVIRIS quicklook images. MFC = McFait Canyon. MC = Mitchell Canyon. SC = Sunshine Canyon.

View full-resolution file 


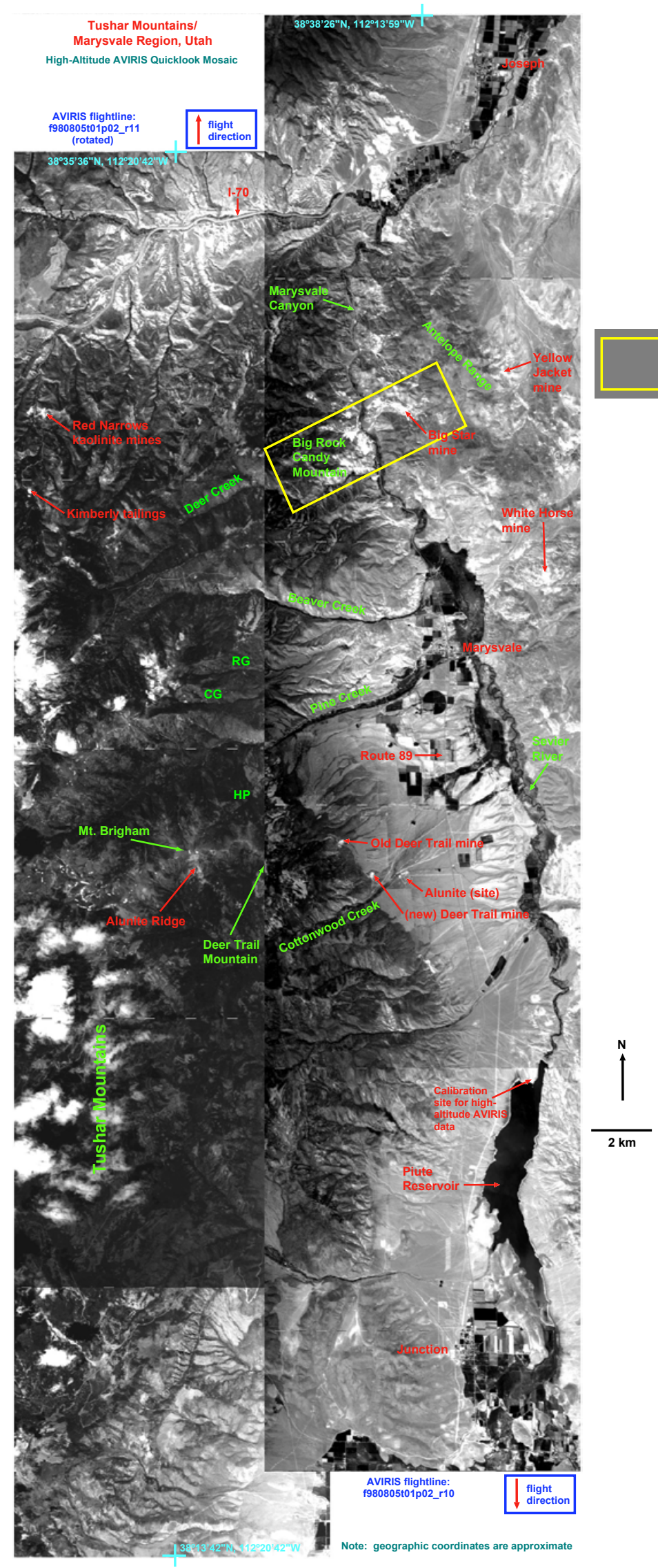

Approximate coverage of low-altitude AVIRIS data
over Big Rock Candy Mountain

RG - Revenue Gulch

CG - California Gulch

HP - Hennesy Point

Figure 4. Location map of Tushar Mountains/Marysvale region, Utah. Background is an uncontrolled mosaic of high-altitude AVIRIS quicklook images. Yellow rectangle indicates approximate coverage of low-altitude AVIRIS flightline over Big Rock Candy Mountain. RG = Revenue Gulch. $\mathrm{CG}=$ California Gulch. HP = Hennesy Point. View full-resolution file 


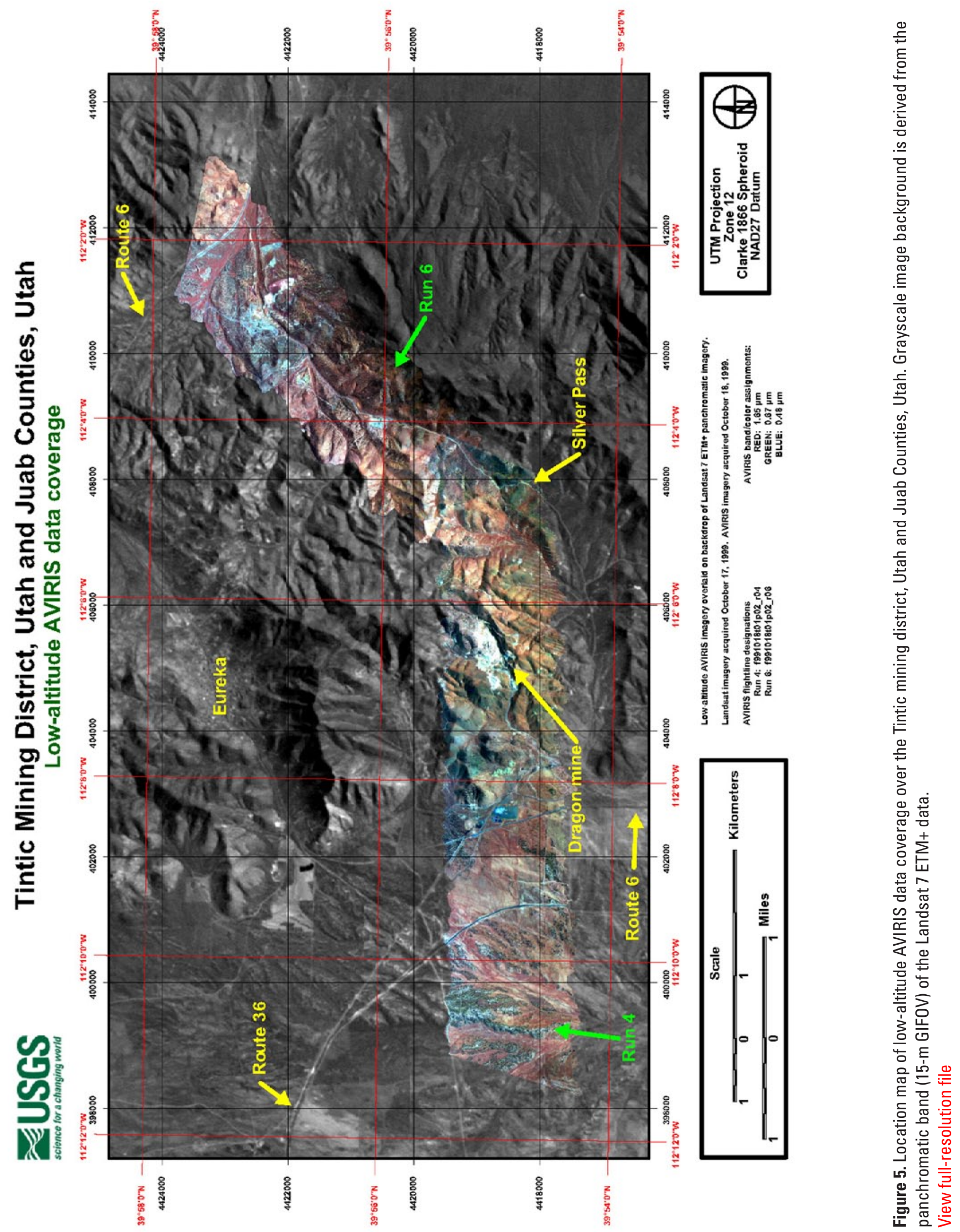


Table 1. Ground sites used for reflectance calibration of high-altitude AVIRIS data.

\begin{tabular}{|c|c|c|}
\hline Study area & Calibration site & Secondary spectral polishing site \\
\hline $\begin{array}{c}\text { East Tintic Mountains (fig. 2) and } \\
\text { Oquirrh Mountains (fig. 3) }\end{array}$ & $\begin{array}{c}\text { Old Saltair Beach or salt flat, south shore of } \\
\text { Great Salt Lake } \\
\left(40^{\circ} 46^{\prime} 15.6^{\prime \prime} \text { N., } 112^{\circ} 10^{\prime} 4.75^{\prime \prime} \mathrm{W} .\right)\end{array}$ & $\begin{array}{l}\text { Waste rock piles at the Dragon mine, } \\
\text { Tintic mining district } \\
\left(39^{\circ} 54^{\prime} 57.3^{\prime \prime} \text { N., } 112^{\circ} 6^{\prime} 33.3^{\prime \prime} \mathrm{W} .\right)\end{array}$ \\
\hline $\begin{array}{c}\text { Tushar Mountains/Marysvale } \\
\text { region (fig. 4) }\end{array}$ & $\begin{array}{c}\text { Parking lot at boat ramp, Piute Lake State Park, } \\
\text { north end of Piute Reservoir } \\
\left(38^{\circ} 19^{\prime} 11^{\prime \prime N} ., 112^{\circ} 11^{\prime} 47^{\prime \prime} \text {. }\right)\end{array}$ & $\begin{array}{l}\text { Northeast slopes of } \\
\text { Big Rock Candy Mountain } \\
\left(38^{\circ} 30^{\prime} 49^{\prime \prime} \text { N., } 112^{\circ} 16^{\prime} 3.3^{\prime \prime} \mathrm{W} .\right)\end{array}$ \\
\hline
\end{tabular}

that is present within the AVIRIS data coverage. Table 1 lists the sites used for ground calibration of the high-altitude AVIRIS data covering each of the three study areas. The spectra of these field sites are used to smooth the AVIRIS data by removing residual atmospheric absorptions and sensor artifacts. AVIRIS spectra smoothed in this way may be directly and quantitatively compared to libraries of standard reflectance spectra. The reflectance calibration of the 1998 high-altitude AVIRIS data covering the Oquirrh and East Tintic Mountains is described in detail by Rockwell and others (2002).

Reflectance data derived from the ground calibrations shown in table 1 contained substantial spectral artifacts related to either residual absorptions of atmospheric gases and particulates that were not removed by the ATREM and pathradiance corrections or sensor noise in the $2.0-$ to $2.5-\mu \mathrm{m}$ spectral region. Residual artifacts related to atmospheric water (mainly 0.94 and $1.13 \mu \mathrm{m}$ ) and $\mathrm{CO}_{2}$ (2.01 and $2.06 \mu \mathrm{m}$ ) may become more pronounced for areas at elevations different from that of the ground-calibration site. This effect is caused by the fact that the ground-calibration process corrects the entire AVIRIS data coverage relative to atmospheric conditions at the calibration site. As absorptions related to $\mathrm{CO}_{2}$ increase in depth with increased atmospheric path length, reflectance spectra of pixels sampled from high elevations will show smaller $\mathrm{CO}_{2}$ absorption-feature depths than pixels sampled from lower elevations. Overcorrection for $\mathrm{CO}_{2}$ will occur at elevations higher than the calibration site, resulting in positive "humps" at the $\mathrm{CO}_{2}$ absorption-feature locations. Conversely, undercorrections for $\mathrm{CO}_{2}$ will occur for areas at lower elevations than the calibration site. The reflectance data derived from the calibration site at the Saltair Beach on the shores of Great Salt Lake were markedly affected by residual absorptions within short horizontal and vertical distances from the calibration site because of the presence of a distinct microclimate associated with the lake.

To alleviate these deficiencies in the reflectance data, additional areas of known composition located near the average elevations for a study area were used to verify and further refine the accuracy of the calibrations and derive any residual corrections for path radiance. Reflectance spectra of bright (high surface albedo) areas of known composition were sampled from the calibrated high-altitude AVIRIS data and edited, or "polished," to identify and remove artifacts related to residual absorptions of atmospheric gases, particulates, and sensor noise. Corrections for the subtle artifacts identified in this way were incorporated into the data used for the original reflectance calibrations, and the AVIRIS radiance data were recalibrated to reflectance format by using this refined calibration data. Sites used for this secondary reflectance-based spectral polishing are also listed in table 1 .

\section{Calibration of Low-Altitude AVIRIS Data}

As no field spectra were obtained during the low-altitude overflights and the flightlines did not cover the calibration sites used for the high-altitude data, reflectance-calibrated high-altitude AVIRIS spectra were used to simulate field spectra for the low-altitude data calibration. The process of reflectance calibration described in Rockwell and others (2002) was applied to the low-altitude AVIRIS data with the exception that edited high-altitude AVIRIS spectra were used as simulated field spectra of ground-calibration sites. Spectra of areas of bright soil and rock covered by both the high- and low-altitude AVIRIS data were sampled from the reflectance-calibrated high-altitude AVIRIS data, averaged, and edited to remove residual atmospheric absorptions. This "boot-strapping" procedure of using high-altitude AVIRIS data to calibrate overlapping flightlines of low-altitude data is further described in Rockwell and others (1999). For the two flightlines acquired over the Tintic mining district (figs. 6 and 7), a patch of bright soil in the Tintic Valley was used as the calibration site (fig. 6). Figure 8 shows the calibration site used for the AVIRIS flightline over Big Rock Candy Mountain in the Marysvale volcanic field.

\section{Georectification of AVIRIS Data}

The high-altitude AVIRIS data were collected from a NASA ER-2 aircraft flying at an altitude of $\approx 20 \mathrm{~km}$. Although the ER-2 was designed to simulate conditions on a stable satellite platform and is equipped with a roll-compensation system, geometric distortions related to variations in aircraft roll, pitch, yaw, and velocity are present in the AVIRIS data. These distortions must be removed prior to image georeferencing to a map projection if positional errors are to be minimized, especially in areas of significant terrain relief. The USGS AVRECGEN and AVRECTFY algorithms were used to remove these distortions; the algorithms are based on modeling the look-point equation for each AVIRIS pixel using the engineering and navigation data that are recorded simultaneously with the spectral image data (Clark and others, 1998). 


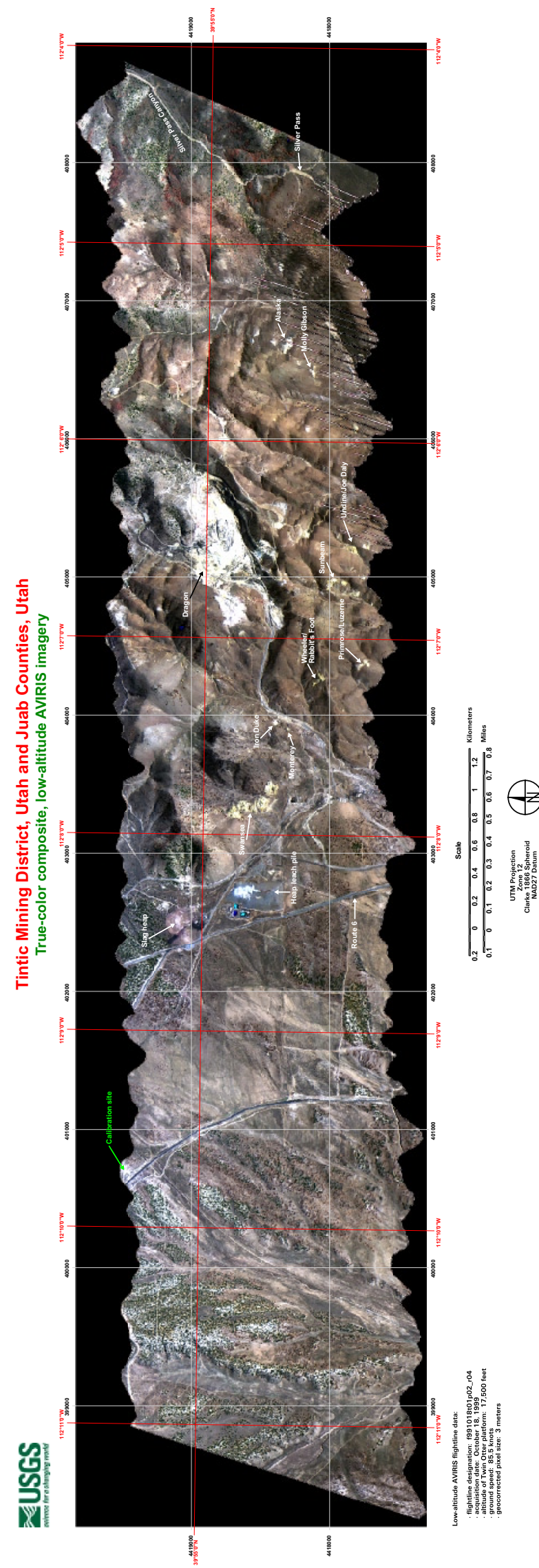

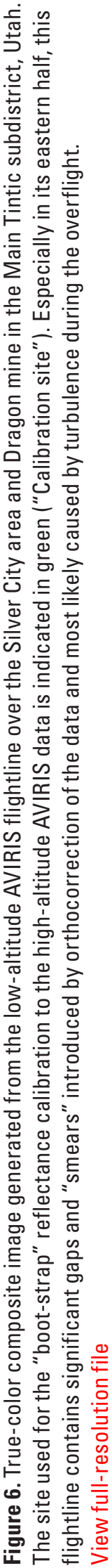




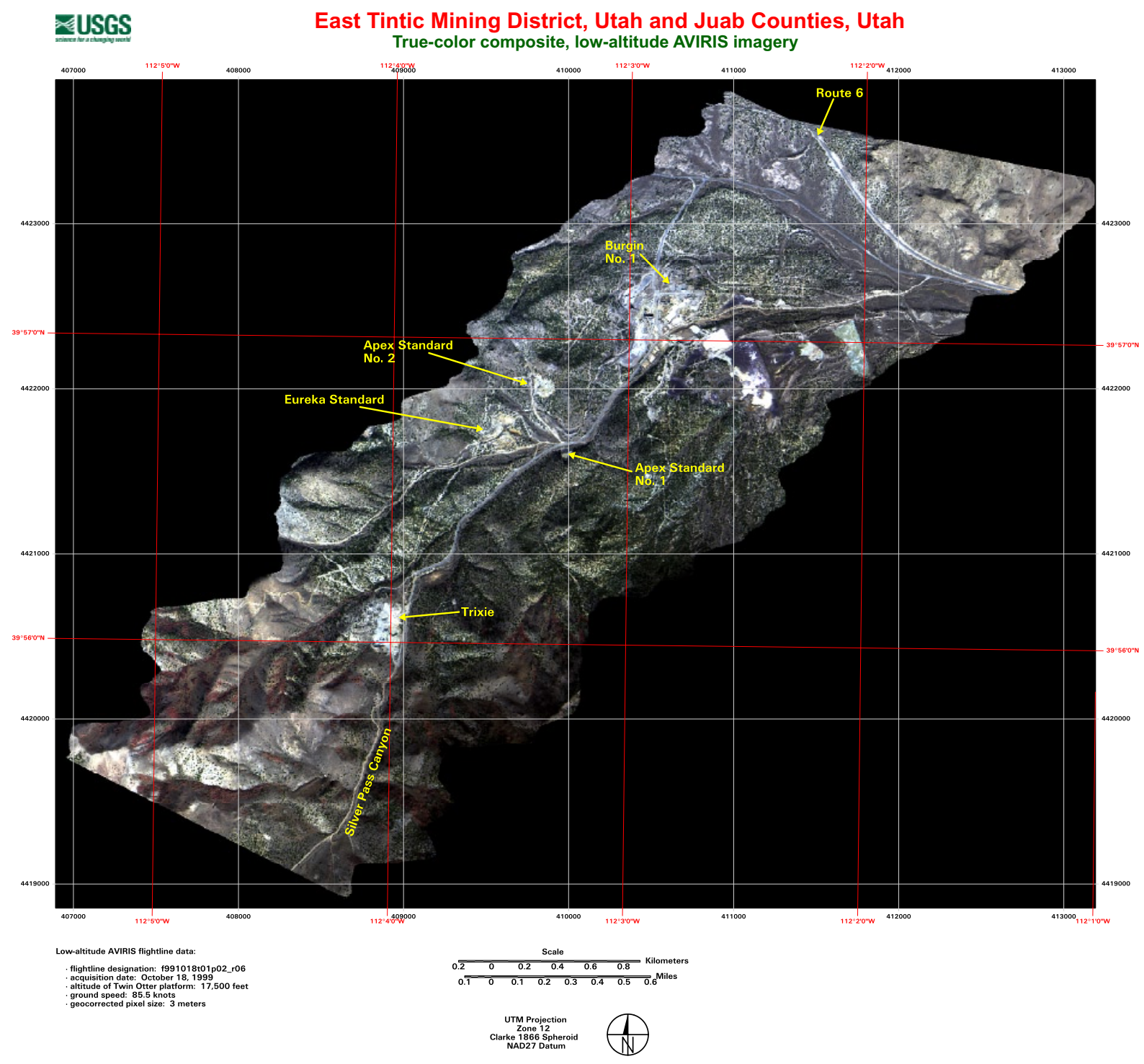

Figure 7. True-color composite image generated from the low-altitude AVIRIS flightline over the East Tintic subdistrict, Utah. Senescing deciduous vegetation is visible in reddish tones in mountain valleys to the southwest of the Trixie mine in this autumn image.

View full-resolution file

The low-altitude AVIRIS data described here were acquired from a propeller-driven Twin Otter aircraft flying at 5.33-km altitude. The distortions caused by roll, pitch, yaw, and velocity variations are much more pronounced in data acquired by the low-altitude platform than in data from the ER-2. Therefore, a different algorithm was used to remove these distortions from the low-altitude data (Boardman, 1999). This method does not remove topography-induced image distortions, but does remove the aircraft-induced and scan mirror-induced distortions that dominate AVIRIS low-altitude data.

After distortion removal, the high-altitude data were georeferenced to the Universal Transverse Mercator map projection by using a second-order polynomial transformation with control points selected from USGS 1:24,000-scale Digital
Raster Graphics. The low-altitude data were georeferenced by using rubber-sheeting functions (Watson, 1992).

\section{Spectral Analysis}

The USGS Tetracorder expert system was used for spectral analysis of the AVIRIS data (Clark, Swayze, Livo, and others, 2003). This semiautomated software system independently compared the spectrum of each pixel in the AVIRIS data to a digital library of standard laboratory reference spectra of minerals, mineral mixtures, water, snow, man-made objects, and vegetation. The library reference spectra used by the Tetracorder software are available in published spectral libraries (Rockwell, 2002; Clark, Swayze, Wise, and others, 2003). One 


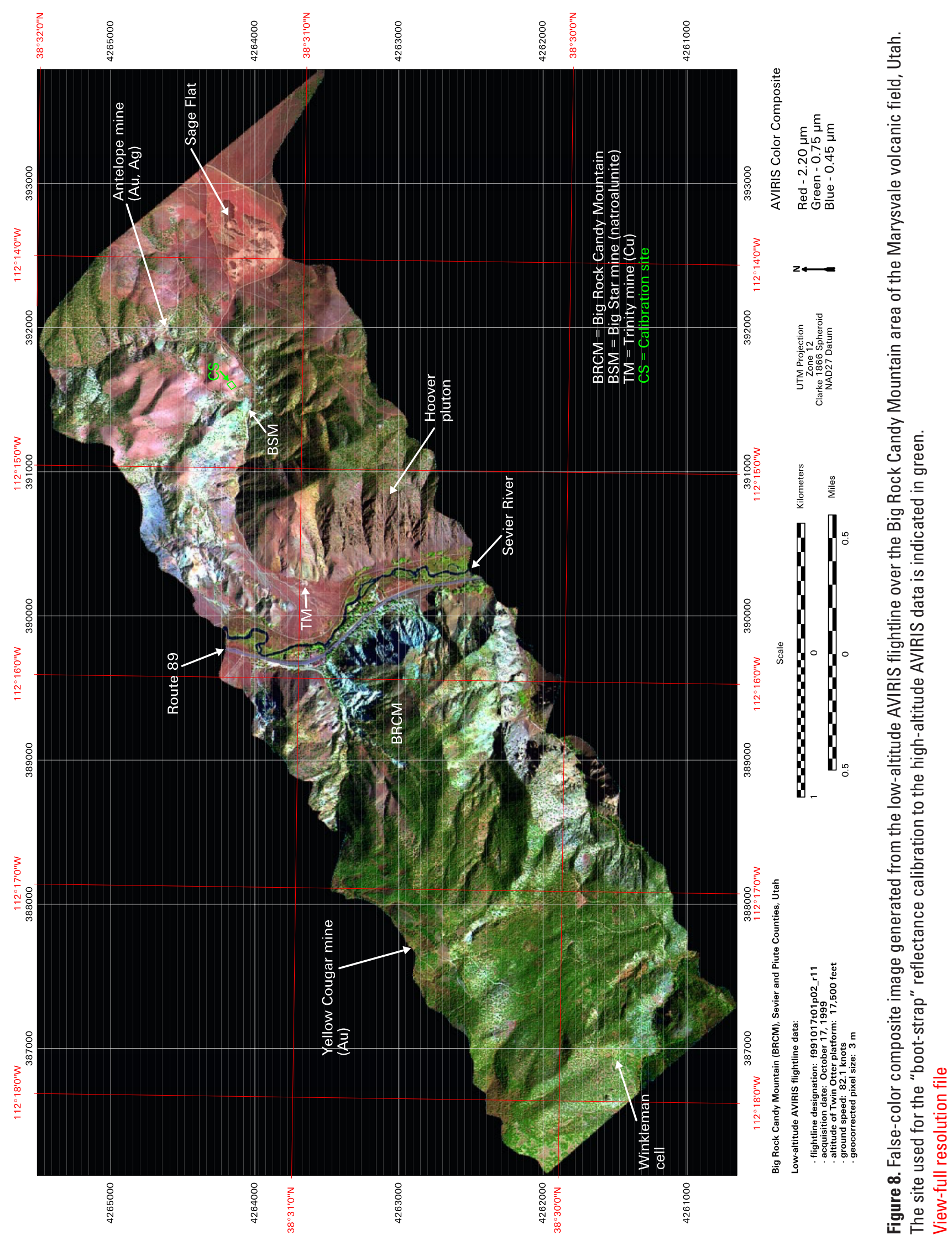


or more diagnostic spectral absorption features were analyzed according to a detailed set of rules for each reference material. This analysis generated quantitative digital image maps of (1) absorption-feature depth in the image spectra and (2) modified least-squares fit of image spectra to library reference spectra across defined spectral intervals (continua) for each reference material. In general, absorption-feature depth is proportional to the spectral abundance of a material in a pixel, given a constant grain size (Clark, 1999).

The spectrum of each pixel of AVIRIS data was analyzed separately for several groups of surface materials. These can be detected independently of each other because they have diagnostic absorption features in different wavelength regions of the electromagnetic spectrum. For every pixel, modified least-squares fit values were generated for each reference material belonging to a particular material group. The material with the highest fit value for that group was selected as the spectrally identified material within that group. The reliability of the mapping results is directly proportional to both high feature depths in the image spectra and high degrees of fit. Therefore, the image maps showing feature depth and feature fit are multiplied to generate a "fit $\times$ depth" image for each identified material (Clark, Swayze, Livo, and others, 2003). Pixels with high fit $\times$ depth values are most likely to be an accurate identification of a given material. Pixels not identified as a particular material in a group (that is, their fit and (or) depth values were below a user-defined threshold) were assigned a fit $\times$ depth value of zero for that group. Therefore, for each group of surface materials (for example, the iron-bearing mineral group or the clay, sulfate, mica, carbonate, and hydrous silica mineral group), a given pixel may have a positive value (representing an identification) for only one material, or it may not be identified as any material in that group. The fit $x$ depth image map is used for the final interactive analysis of the mapping results. The Tetracorder system identifies only the material or mixture of materials that is spectrally dominant in a pixel, meaning that the absorption feature of the identified material is sufficiently unobscured by features of other materials to allow its recognition by spectral analysis. Therefore, identification of the spectrally dominant material in a spectrum does not imply that other materials do not also exist in that pixel.

A separate map can be generated for each material group. For this report, two types of maps were generated to show the distribution of the following materials: (1) those having absorption features in the 0.35 - to $1.35-\mu \mathrm{m}$ spectral region, such as ironbearing minerals, snow, ice, and water; and (2) those having vibrational absorption features in the 1.45 - to $2.50-\mu \mathrm{m}$ spectral region, including such minerals as phyllosilicates (micas and clays bearing Al-OH or Mg-OH), sulfates, carbonates, amphiboles, hydrous quartz (chalcedony and opal bearing Si-OH bonds), and epidote (a sorosilicate mineral bearing calcium and Al-OH and (or) Fe-OH bonds). The AVIRISderived maps of surficial materials presented in this report consist of color-coded pixels identified as specific materials on a grayscale background image of a single AVIRIS band. In generating the final maps, each material is assigned a discrete color. The fit $\times$ depth image corresponding to a particular material may be digitally stretched so that pixels of all fit $\times$ depth values will be represented by a single color ("hard stretch"), or the image can be stretched so that the fit $\times$ depth values will be represented by a range of brightness levels for a given color ("continuous stretch"). For example, in the case of a continuous stretch, pixels with the highest fit $\times$ depth values will be represented by the color chosen for that material, and pixels with decreasing fit $\times$ depth values will be represented by successively darker shades of that color. Hard stretches are used more frequently than continuous stretches in making maps showing many different materials, as maps showing many shades of colors can be difficult to interpret. Minerals and mineral assemblages for which continuous stretches were used are marked with a "C" in the map explanations (legends).

\section{Map Explanations}

The explanations (legends) with the high-altitude AVIRIS mineral maps presented here have been designed to facilitate interpretation of the imagery. These explanations relate identified minerals and mineral assemblages to associated acid-producing potential (APP) and acid-neutralizing potential (ANP). The explanations for the maps of iron-bearing minerals are organized in order of decreasing APP from top (high APP) to bottom (low APP). APP can be considered to be inversely proportional to $\mathrm{pH}$. In the explanations for the maps of clay, sulfate, mica, and carbonate minerals, minerals and mineral assemblages that either may occur with pyrite (for example, dickite) or have APP themselves (for example, jarosite) are indicated with an asterisk.

\section{Verification of Spectral Analysis Results}

The results of the mineral mapping were verified by field checking and (or) interactive comparison of AVIRIS spectra with standard library spectra. Selected mapping results were also verified by using X-ray diffraction (XRD) analysis of field samples. The appendix shows the XRD results of many field samples, along with sampling locations and other information. Appendix tables A1 and A3 include the Tetracorder mapping results for AVIRIS pixels in the vicinity of the sample collection locations. Tetracorder mapping results show several different minerals for a given location, meaning that either (1) mineral mixtures were directly identified in the AVIRIS data or (2) various individual minerals were spectrally identified in the area surrounding the location and the exact AVIRIS pixel corresponding to the sampling location could not be reliably identified. In cases where field checking and (or) laboratory analysis identified errors in the Tetracorder mapping, mapping rules were reviewed and modified and (or) new standards were added to the spectral library of reference materials. In the latter case, rock samples collected in the field were analyzed by XRD, and their reflectance spectra were measured in the laboratory. Mapping rules were then developed for one or more diagnostic absorption features present in the laboratory spectra, and the 
spectra were added to the spectral reference library. The Tetracorder expert system was then rerun on the AVIRIS data by using the modified mapping rules and expanded spectral library. Some of the field samples that were added to the spectral library are listed in blue in the appendix. Rockwell (2002) has documented the spectroscopic properties of these samples and has defined the absorption features in each sample spectrum that were analyzed by the Tetracorder expert system.

To exemplify a Tetracorder mapping error that was remedied as a part of this research, maps of the southwestern Oquirrh Mountains generated in 1999 (McDougal and others, 1999) can be compared with those presented in this report. On the 1999 maps of clay minerals, most of the outwash deposits in Rush Valley emanating from the mouth of Mercur Canyon (fig. 3) were spectrally identified as the clay mineral halloysite $\left(\mathrm{Al}_{2} \mathrm{Si}_{2} \mathrm{O}_{5}(\mathrm{OH})_{4}\right)$. XRD analyses of rock from these alluvial deposits did not identify halloysite, but indicated that kaolinite and muscovite are common (appendix table A2). Kaolinite and muscovite are abundant in the Oquirrh Mountains in the vicinity of Mercur Canyon, and mixtures of these minerals are spectrally similar to halloysite near the Al-OH absorption feature at $2.2 \mu \mathrm{m}$. The Tetracorder mapping rules for kaolinite + muscovite mixtures involve library and AVIRIS comparisons of Al-OH absorption features at both $2.20 \mu \mathrm{m}$ (present in both kaolinite and muscovite) and $2.35 \mu \mathrm{m}$ (muscovite only). In nature, the depth of the absorption feature at $2.35 \mu \mathrm{m}$ is highly variable for kaolinite + muscovite mixtures. Accordingly, the Tetracorder mapping rules for such mixtures were modified to simply check for the presence of an absorption band at $2.35 \mu \mathrm{m}$ rather than include the least-squares fit for this band in the combined overall fits for the reference spectrum of the kaolinite + muscovite mixture. This modification resulted in fewer misidentifications of halloysite, whereas correct identifications of halloysite at the Dragon mine in the Tintic mining district were maintained. As mixtures of kaolinite, muscovite (or illite), and (or) smectite are very common in mine-waste rocks, this modification was important to improve Tetracorder mapping accuracy in abandoned mine lands. As illite, muscovite, and sericite (a field term for white, fine-grained potassium mica) are very difficult, if not impossible, to differentiate by using spectroscopic remote-sensing data with the bandwidth and sampling characteristics of AVIRIS data, all references to these minerals in terms of AVIRIS mapping results are interchangeable. After the material maps presented in this report were generated, we found that spectral confusion can occur between low-aluminum muscovite and mixtures of muscovite and chlorite. Therefore, pixels identified as lowaluminum muscovite on the maps may instead represent muscovite + chlorite mixtures.

Because (1) the Tetracorder expert system is experimental and under constant development and revision and (2) the Earth's surface has inherent mineralogic complexity, 100 percent accuracy of mineral identifications cannot be guaranteed for each AVIRIS pixel. For many of the more common rock-forming minerals, the Tetracorder system is very robust, especially when the minerals occur abundantly in pure or nearly pure form. Although a great effort has been made to include many common mineral mixtures in the Tetracorder spectral library, it is not currently possible to include spectra of every combination of minerals. For this reason, and because Tetracorder only identifies the mineral or minerals that are spectrally dominant in a pixel, it can be assumed that the accuracy of the mineral maps will decrease as the number of constituent minerals in a rock increases. No legal or regulatory actions should be initiated on the basis of the mineral maps alone. Targets of potential significance identified by the mineral maps should be studied in detail in the field and (or) laboratory prior to decision-making regarding a site or watershed.

\section{The East Tintic Mountains and the Tintic Mining District}

\section{Geologic Setting}

The Tintic mining district is located $\approx 95 \mathrm{~km}$ south-southwest of Salt Lake City, Utah, in the East Tintic Mountains (see project index map at http://speclab.cr.usgs.gov/earth.studies/Utah-1/ utahproj_large.jpg). The town of Eureka lies at the northern end of the district. The geology of the area surrounding the Tintic mining district has been described by Lovering (1949), Morris and Lovering (1961), Morris (1968, 1975), and Morris and Mogensen (1978). A thick sequence of Precambrian and Paleozoic sedimentary rocks (quartzites, limestones, dolomites, and shales) was deformed during the Cretaceous Sevier orogeny into largeamplitude, north-trending, asymmetric folds with overlapping thrust sheets and associated high-angle faults. The district is located at the intersection of two lineament sets, the north-trending Wasatch hinge line and the east-trending Tintic mineral belt (Krahulec, 1996). During the early to middle Oligocene, at least four extrusive and intrusive igneous events occurred that covered an ancient mountain range in the district with a composite volcano consisting of latite tuffs, flows, welded tuffs, and agglomerates. The first Oligocene volcanic event involved the eruption of the Packard Quartz Latite (Tp) and culminated with the intrusion of the Swansea Quartz Monzonite porphyry stock (Ts) and related dikes near the center of the Tintic district (32.75 Ma, figs. 9 and 10). Morris (1975) proposed that a 13.6-km-wide caldera was then formed in the southern part of the district (inferred rim shown in magenta in fig. 9). The existence of this caldera was supported by Hannah and Macbeth (1990) and Hannah and others (1990, 1991). Stoeser (1993) proposed that multiple caldera-forming events occurred in the area during the Oligocene and that volcanic sequences of this age that are exposed in the East Tintic Mountains may be related to a caldera in the West Tintic Mountains (the Maple Peak caldera). Stoeser (1993) also proposed that the Maple Peak caldera may have been moved to the west by the same extensional tectonics that formed the Tintic Valley, which separates the East Tintic and West Tintic Mountains.

The second volcanic event resulted in the deposition of the Tintic Mountain Volcanic Group and culminated with the intrusion of the Sunrise Peak Monzonite Porphyry stock and many related plugs, dikes, and extensive latite sills at the southern and eastern edges of the district (fig. 9). Near the end 


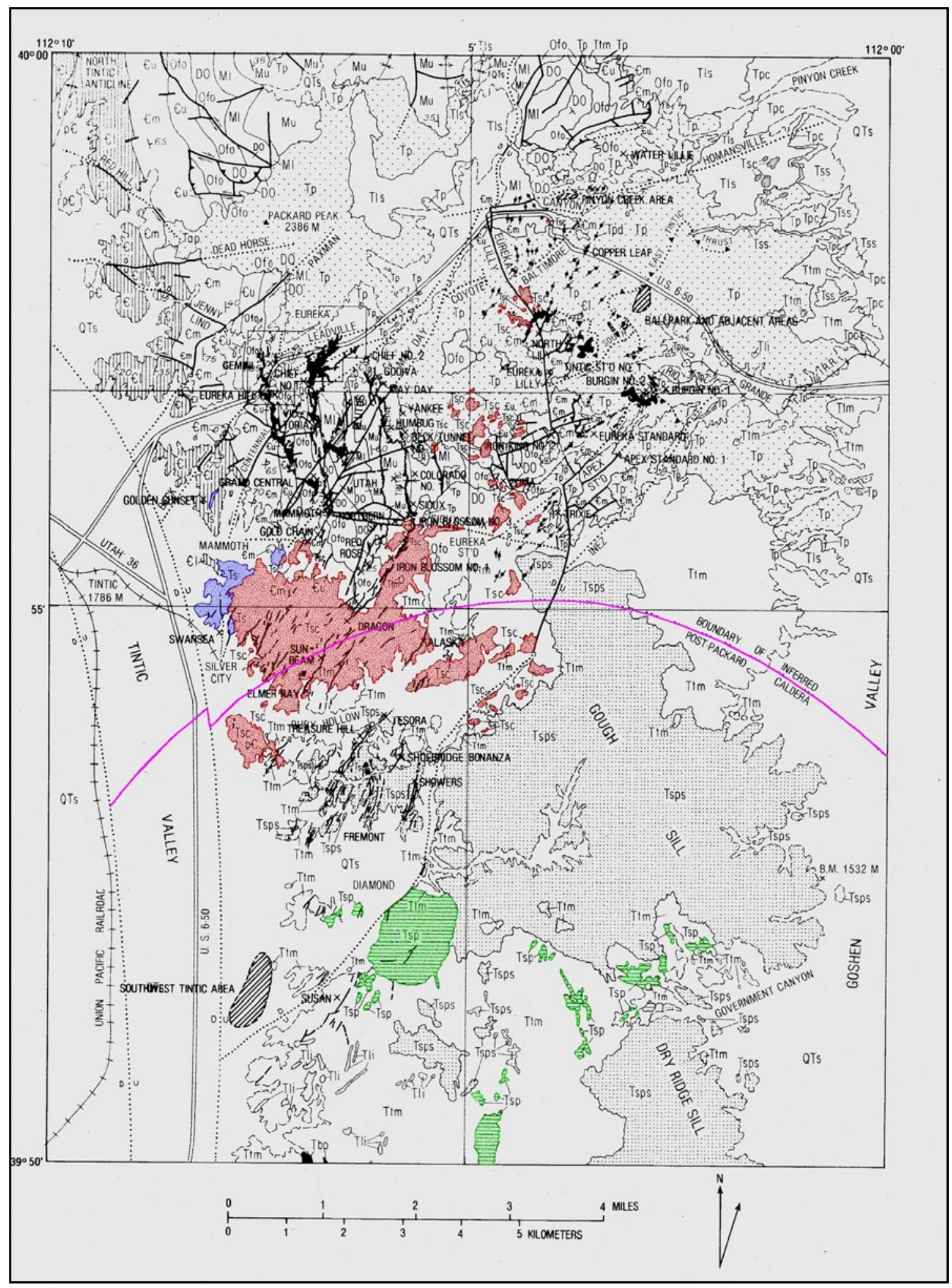

Figure 9. Geologic map of the Tintic mining district. Refer to figure $\mathbf{1 0}$ for explanation showing geologic units. Blue = Swansea Quartz Monzonite (Ts) stock and related intrusive rocks. Green = Sunrise Peak Monzonite Porphyry (Tsp) stock and related intrusive rocks (contemporaneous Gough and Dry Ridge sills, Tsps, are in black and white dot pattern). Red = Silver City Monzonite (Tsc) stock and related plutons. Modified from Morris and Mogensen (1978).

View full-resolution file 
EXPLANATION

Surticial and valley-fill deposits

Tss

Silver Shield Quartz Latite and related teoder dike

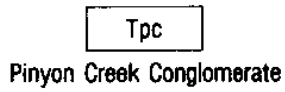

$$
\begin{aligned}
& \hline- \text {-Tbp } \\
& \text { Breccia pipe }
\end{aligned}
$$

$$
\text { IsC? }
$$

Monzonite porphyry of Silver City stock and related plutons

$$
\operatorname{ratpd} x
$$

Pebble dikes and related dikes of monzonite porphyry

$$
\text { TIs }
$$

Laguna Springs Volcanic Group

(Tintic Delmar Latite, Pinyon Queen Latite, and North Standard Latite)

$$
\text { spspe }
$$

Sunrise Peak Menzonite Porphyy and related intrusive rocks Tsp, crosscutting piutons

Tsps, extensive sills

$$
\text { Latite intrusive rocks }
$$

(Big Canyon Latite, Latite Ridge Latite, and Copperopolis Latite)

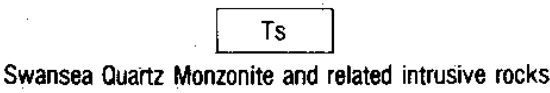

$$
\begin{gathered}
\because \because \text { Tp } \\
\text { Packard Ouartz Latite } \\
\text { Tap }
\end{gathered}
$$

Apex Conglomerate

$$
\text { Mu }
$$

Upper Mississippian rocks

(Great Blue Formation, Humbug Formation, and Deseret Limestone)

$$
[-\bar{M}-\overline{1}]
$$

Mostly Lower Mississippian rocks (Gardison Limestone and Fitchville Formation; includes some Devonian strata at base)
Oevonian to Ordovician rocks

(Pinyon Peak Limestone, Victoria Formation, and Bluebell Dolomite)

(Cole Canyon Dolomite, Bluebird Dolomite, Herkimer Limestone,

Dagmar Dolomite, Teutonic Limestone, and Ophir Formation)
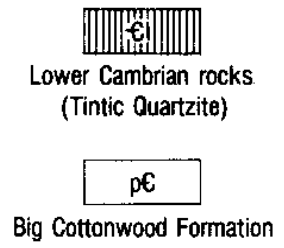

Big Cottonwood Formation

Contact

Dashed where approximately located

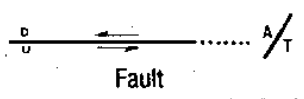

(Dotted where concealed; $U$, upthrown side; $D$, downthrown side; arrows show direction of relative movement. In section: $A$, relative movement away from observer; $T$, toward observer

\section{Thrust fault}

(Dotted where concealed; Sawteeth on side of upper plate)

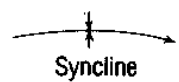

(Showing trace of axial plane and plunge of axiș)

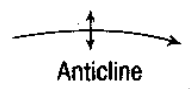

(Showing trace of axial plane and plunge of axis)

$\stackrel{50}{1}$

Strike and dip of beds

$$
70
$$

Strike and dip of overturned beds

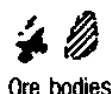

Figure 10. Explanation for geologic map shown in figure 9. From Morris and Mogensen (1978). 
of Oligocene volcanism ( $\approx 31.5 \mathrm{Ma}$ ), the Silver City Monzonite stock and related dikes and plugs were intruded along a northnortheast-trending zone extending from the northwest boundary of the caldera; this igneous activity initiated circulation of hydrothermal fluids through faults, fractures, and breccia zones in the Paleozoic sedimentary rocks and older Oligocene volcanic rocks. These hot fluids pervasively altered the country rock and ultimately resulted in deposition of ore minerals. The youngest intrusive rock in the district is the quartz monzonite porphyry of Diamond Gulch, which intruded the southern part of the Silver City stock and is exposed along the north edge of Ruby Hollow (Krahulec, 1996). This stock is thought to be responsible for copper mineralization at the southwestern edge of the Tintic district. In the Miocene (17 Ma), postore dikes and associated flows of quartz monzonite porphyry were emplaced. Faulting related to Basin and Range extensional tectonics took place from the Oligocene to the Holocene, sometimes reactivating older faults in the district.

\section{Ore Deposits and Alteration}

Lovering (1949) recognized the sequence of events involving hydrothermal alteration and mineralization in the Tintic district: (1) pervasive dolomitization of limestone beds, (2) propylitic alteration, (3) argillic alteration (including formation of alunite, kaolinite, etc.), (4) silicification, calcification, and pyritization (post-monzonite intrusion), and (5) ore deposition (quartz, barite, sericite, orthoclase, rhodochrosite, and ore minerals). Late-stage, high-temperature $\left(\approx 257^{\circ}-300^{\circ} \mathrm{C}\right)$ fluids created epigenetic polymetallic base and precious metal deposits as replacements in favorable carbonate beds, replacement veins, and fissure veins (Morris, 1990). Primary ore minerals include galena, sphalerite, argentite, tetrahedrite-tennantite, enargite, sulfosalts, native gold and silver, and secondary oxides. Alteration minerals include alunite, various clay and carbonate minerals, illite (sericite), and pyrite. Secondary gypsum and jarosite (after pyrite) are also present. Primary gangue (waste) minerals include quartz, barite, calcite, dolomite, and rhodochrosite. Table 2 lists the dominant gangue minerals as a function of ore type in the district.

Most ore deposits in the Tintic district occur as replacement bodies, replacement veins, and fissure veins (Morris, 1968). A majority of the metals produced from the Tintic district were derived from ore bodies that have replaced favorable horizons in folded and faulted Paleozoic carbonate rocks. Figure $\mathbf{1 1}$ is a map of the Tintic district showing the principal mines and plan views of the major underground ore bodies in the district. Metal production revealed strong patterns of horizontal zonation across the district. Although lead and silver ores were common throughout the district, figure 12 shows that zinc was mainly produced from the northernmost sections of the main replacement ore zones, whereas gold (not shown) and copper were common mainly in the southern part of the district in the area surrounding the Silver City Monzonite stock. The central part of the district (located between the lines showing copper and zinc occurrence limits in fig. 12) was known chiefly for lead and silver production. In general, $\mathrm{Pb} / \mathrm{Zn}$ and $\mathrm{Ag} / \mathrm{Pb}$ ratios decrease toward the north in the district.

Drilling at the southwestern edge of the Tintic district has identified the Southwest Tintic (SWT) porphyry copper deposit (fig. 9) (Krahulec, 1996). This deposit, which had not been mined as of summer 2004, has been characterized as a high-sulfide, low-copper porphyry system associated with the quartz monzonite porphyry stock of Diamond Gulch. The deposit is associated with intense and strongly zoned hydrothermal alteration, some of which is exposed at the surface. The richest copper grades are found in stockworks of quartz \pm pyrite \pm chalcopyrite \pm magnetite \pm molybdenite veins that are largely restricted to a biotite-rich zone at the core of the deposit. A shallow supergene chalcocite blanket is present beneath alluvium in Diamond Gulch 1-3 km to the southwest of Horseshoe Hill (fig. 2). Phyllic, or quartz-sericite-pyrite (QSP), alteration surrounds the core and is exposed in the vicinities of Horseshoe Hill, Treasure Hill, and Ruby Hollow. Within the QSP zone, clay minerals increase in abundance relative to quartz with increased distance from the potassic core of the deposit. A propylitic envelope consisting of an inner zone of actinolite and epidote and an outer zone of calcite and chlorite surrounds the QSP zone. The alteration zones are highly elongated along a northeast-trending structure, which has been interpreted as a tear fault formed during the Jurassic.

\section{Mining History}

The Tintic district was discovered in 1869 , and production of rich polymetallic ores steadily increased, peaking in 1921. Production declined from 1921 until the mid 1950s, when new discoveries in the East Tintic subdistrict prompted another burst of mining that lasted until the 1990s. Metal production figures from 1869 to 1976 are shown in table 2. Virtually no metallic ores have been produced from the Main Tintic subdistrict since 1960. Natural caverns formed by dissolution of carbonate rocks were used for mine dewatering, most notably in the Gemini and Chief No. 1 mines adjacent to Eureka.

The most recent mining activity in the Eureka/Tintic area has taken place in the East Tintic subdistrict. The main ore body of the Burgin mine was discovered in 1958 and was mined for $\mathrm{Pb}, \mathrm{Zn}, \mathrm{Ag}$, minor $\mathrm{Au}$ and $\mathrm{Cu}$, and high-silica flux ores until the late 1970s. The Trixie mine, located $2.5 \mathrm{~km}$ southwest of the Burgin, was discovered in the mid 1950s and mined for gold, copper, and silver until the 1990s (Morris, 1990). New gold discoveries were made in the late 1990s in the vicinity of the Trixie mine.

Because of elevated levels of $\mathrm{Pb}, \mathrm{As}, \mathrm{Sb}, \mathrm{Cd}, \mathrm{Hg}, \mathrm{Ag}$, and other metals in the soil, parts of the town of Eureka in the Main Tintic subdistrict are being proposed as a Superfund site (U.S. Environmental Protection Agency, 2001). Remediation efforts have been under way since 2001 (U.S. Environmental Protection Agency, 2002a). 
Table 2. Dominant ore and gangue minerals and production figures, Tintic mining district.

[Modified from Morris (1968) and Cox and Singer (1986); production data from Morris and Mogensen (1978)]

\begin{tabular}{|c|c|c|c|}
\hline \multirow[t]{2}{*}{ Metals } & \multicolumn{2}{|c|}{ Dominant minerals } & \multirow[t]{2}{*}{ Production } \\
\hline & Ore & Gangue & \\
\hline $\mathrm{Zn}(-\mathrm{Mn})$ & Sphalerite (+ rhodochrosite) & Fine-grained, pyritic jasperoid & $\mathrm{Zn}: 187,766,326 \mathrm{~kg}$ \\
\hline $\mathrm{Pb}-\mathrm{Ag}$ & $\begin{array}{l}\text { Galena }+ \text { sphalerite }+ \text { argentite }+ \\
\text { silver sulfosalts } \pm \text { tetrahedrite }\end{array}$ & $\begin{array}{l}\text { Fine-grained jasperoid with barite crystals and } \\
\text { quartz-lined vugs }\end{array}$ & $\begin{array}{l}\mathrm{Pb}: 1,027,879,788 \mathrm{~kg} \\
\mathrm{Ag}: 8,379,982 \mathrm{~kg}\end{array}$ \\
\hline $\mathrm{Cu}-\mathrm{Au}$ & $\begin{array}{c}\text { Enargite-famatinite }+ \\
\text { tetrahedrite-tennantite }+ \text { sphalerite } \\
+ \text { argentite }+ \text { digenite }\left(\mathrm{Cu}_{9} \mathrm{~S}_{5}\right)\end{array}$ & $\begin{array}{c}\text { Medium-grained jasperoid and coarse crystals } \\
\text { of quartz and barite }\end{array}$ & $\begin{array}{l}\mathrm{Cu}: 113,065,576 \mathrm{~kg} \\
\mathrm{Au}: 83,599 \mathrm{~kg}\end{array}$ \\
\hline
\end{tabular}

\section{Mapping and Characterization of Mine Waste in the Tintic Mining District}

Maps of minerals and water were generated from the high- and low-altitude AVIRIS data (figs. 13-18). Minerals were identified in only a small percentage of processed AVIRIS pixels. Most of the region within and surrounding the East Tintic Mountains is covered with dry vegetation including piñon, juniper, sage, grasses, and more dense riparian communities along watercourses. Such vegetation usually obscures the mineral signatures in the underlying soil and bedrock.

Table 3 lists mines in the Tintic district at which jarositebearing rocks were mapped by using AVIRIS data. For the locations of these mines, refer to figures 11 and 13-19. The largest exposures of jarosite-bearing tailings and waste-rock piles are marked with an asterisk in table $\mathbf{3}$. For example, figure 20 shows the size of the waste-rock piles at the Swansea mine site (location shown in figs. 13-16). Future field sampling and chemical analyses could determine whether ground and (or) surface water at these sites is contaminated with heavy metals and whether metal-laden soils exist around the affected areas. The AVIRIS-based maps show that most of the waste-rock piles in the Tintic district are small. Waste-rock material appears to be mostly confined to the mine sites and has not been transported far by alluvial or eolian processes.

Several large waste-rock piles exist on the western and southwestern edges of the town of Eureka. Various minerals were spectrally identified on several of these piles, the surfaces of which are for the most part devoid of vegetation: Chief No. 1, Centennial/Eureka, Gemini, Eureka Hill, and Eagle/Bluebell (mine locations in figs. 11 and 19). These mines are located near the northern end of the north-northwest-trending Gemini ore zone (figs. 11 and 12). Table 4 shows the total production in tons and average ore grades for metals extracted from these mines. This information is included to offer a general idea of which metals may be present in the waste-rock piles of these mines, which were not field checked because they are located on private property. Significant amounts of zinc were produced from the Chief No. 1 and Gemini mines. Several pixels of coarse-grained jarosite surrounded by pixels of goethite and hematite correspond to waste-rock piles associated with the
Chief No. 1 and Centennial/Eureka mines. AVIRIS spectra sampled from these pixels show strong electronic absorptions near $1.00 \mu \mathrm{m}$ that are related to ferric iron, but features diagnostic of jarosite are not obvious. Dolomite, mixtures of calcite and dolomite, and minor calcite were also identified in and around these piles. This area is underlain by Cambrian and Ordovician carbonate-bearing rocks (figs. 9 and 11). These carbonate minerals have the potential to neutralize any acidic solutions produced from the oxidation of sulfide minerals in the piles.

In the East Tintic subdistrict, jarositic waste-rock piles and tailings are located immediately southeast of the Burgin mine (see cover photograph and figs. 7, 13, and 17). No strong spectral evidence for eolian deflation of the flat-lying tailings was identified with the AVIRIS mapping. Abundant jarositic waste rock exists at the Trixie mine and at other mine sites in the subdistrict. The high-altitude AVIRIS data indicated few carbonate-bearing rocks or soils downstream from the mines in the East Tintic subdistrict (fig. 14). However, the increased spatial resolution of the low-altitude AVIRIS data allowed the identification of numerous pixels of calcite and dolomite along roads and scattered throughout this subdistrict (fig. 18). In the hills between the Trixie and Apex Standard No. 1 mines, these spectrally identified carbonate-bearing rocks and soils correspond to field-mapped Middle Cambrian limestones and dolomites (figs. 9 and 10). Other carbonate-bearing soils in the area have not been field checked, but are probably related to eolian dusts, road metal, and (or) propylitically altered igneous rocks. The area downstream (northeast) of the Apex Standard No. 1 mine, including the Burgin mine, is underlain by Quaternary alluvium and Packard Quartz Latite, suggesting that little natural acid-neutralizing potential (ANP) is present.

\section{The Dragon Halloysite Mine}

The participants of the USEPA/USGS Utah Abandoned Mine Lands Imaging Spectroscopy Project (U.S. Environmental Protection Agency and U.S. Geological Survey, 2002) selected the Dragon mine as a site for testing and comparing methods of mineral mapping with imaging spectroscopy data. The mine is located in the Main Tintic subdistrict $4 \mathrm{~km}$ south of the town of Eureka. The mine initially exploited deposits of primary hematite for use as smelter flux. In 1938, rich deposits of the 


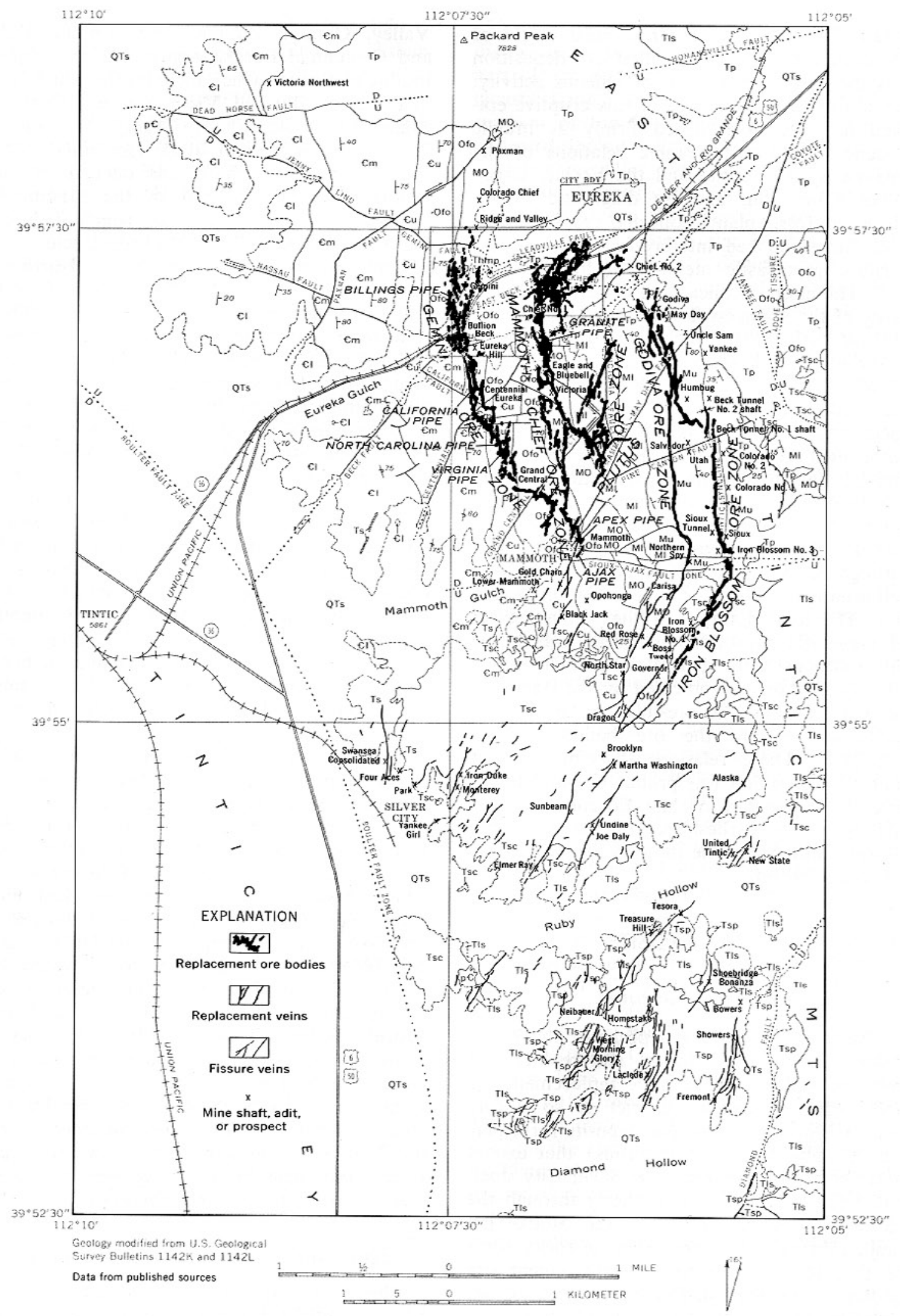

Figure 11. Map of Main Tintic subdistrict showing mines and plan views of ore bodies. For description of map units, see figure 10. From Morris (1968).

View full-resolution file 


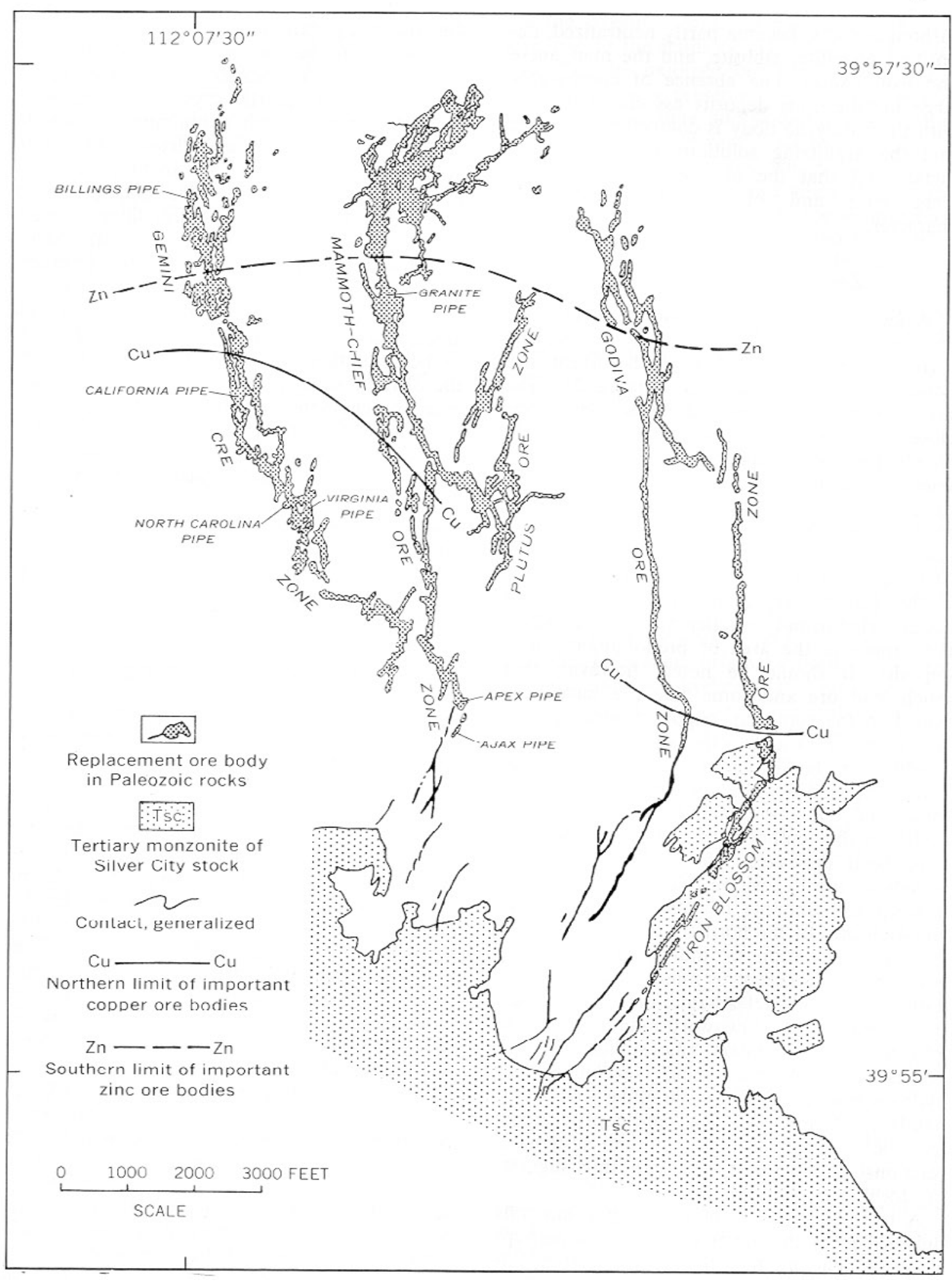

Figure 12. Map of replacement ore bodies, showing generalized compositional zonation. From Morris (1968). 

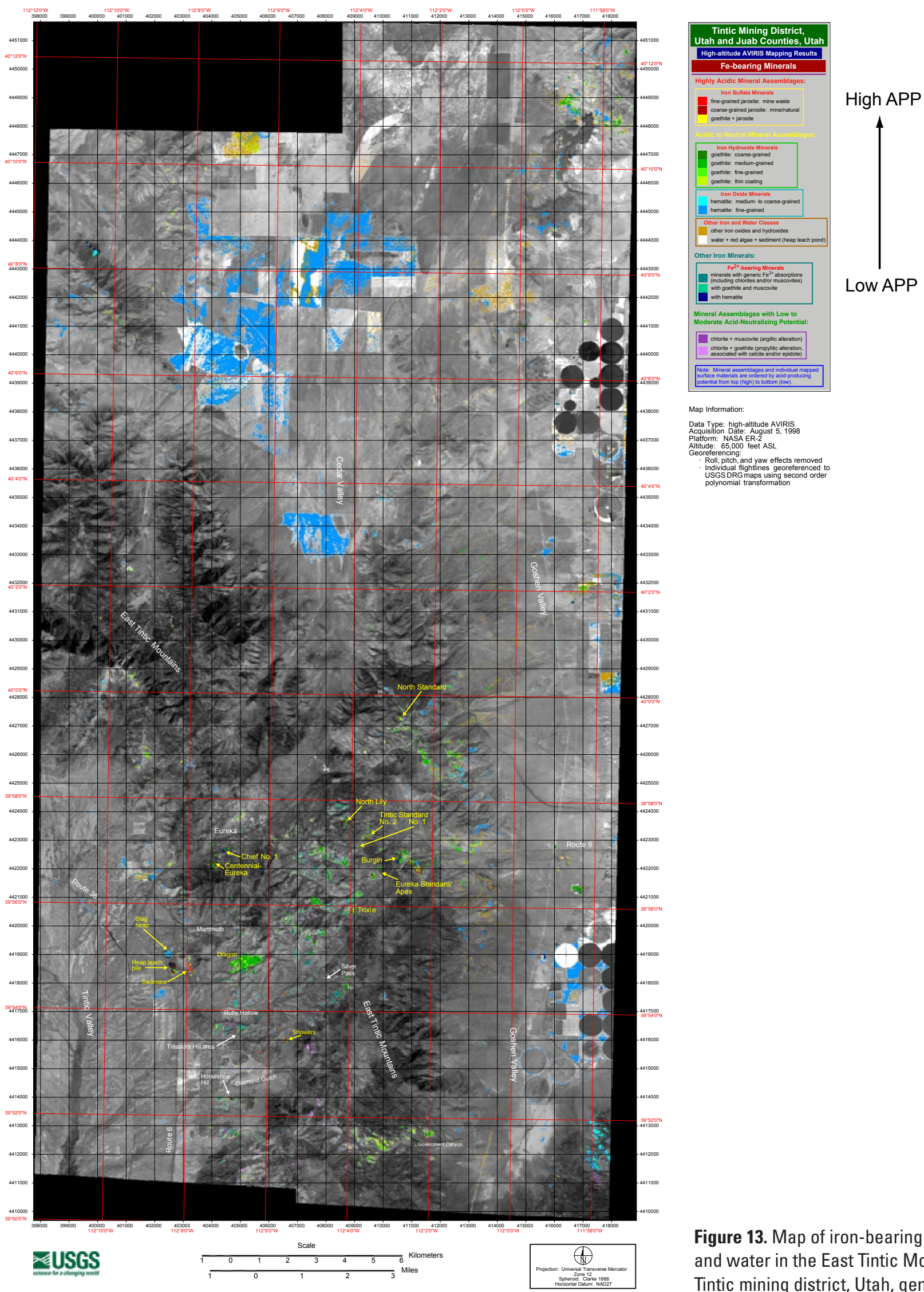

Figure 13. Map of iron-bearing minerals and water in the East Tintic Mountains and Tintic mining district, Utah, generated from high-altitude AVIRIS data.

View full-resolution file 

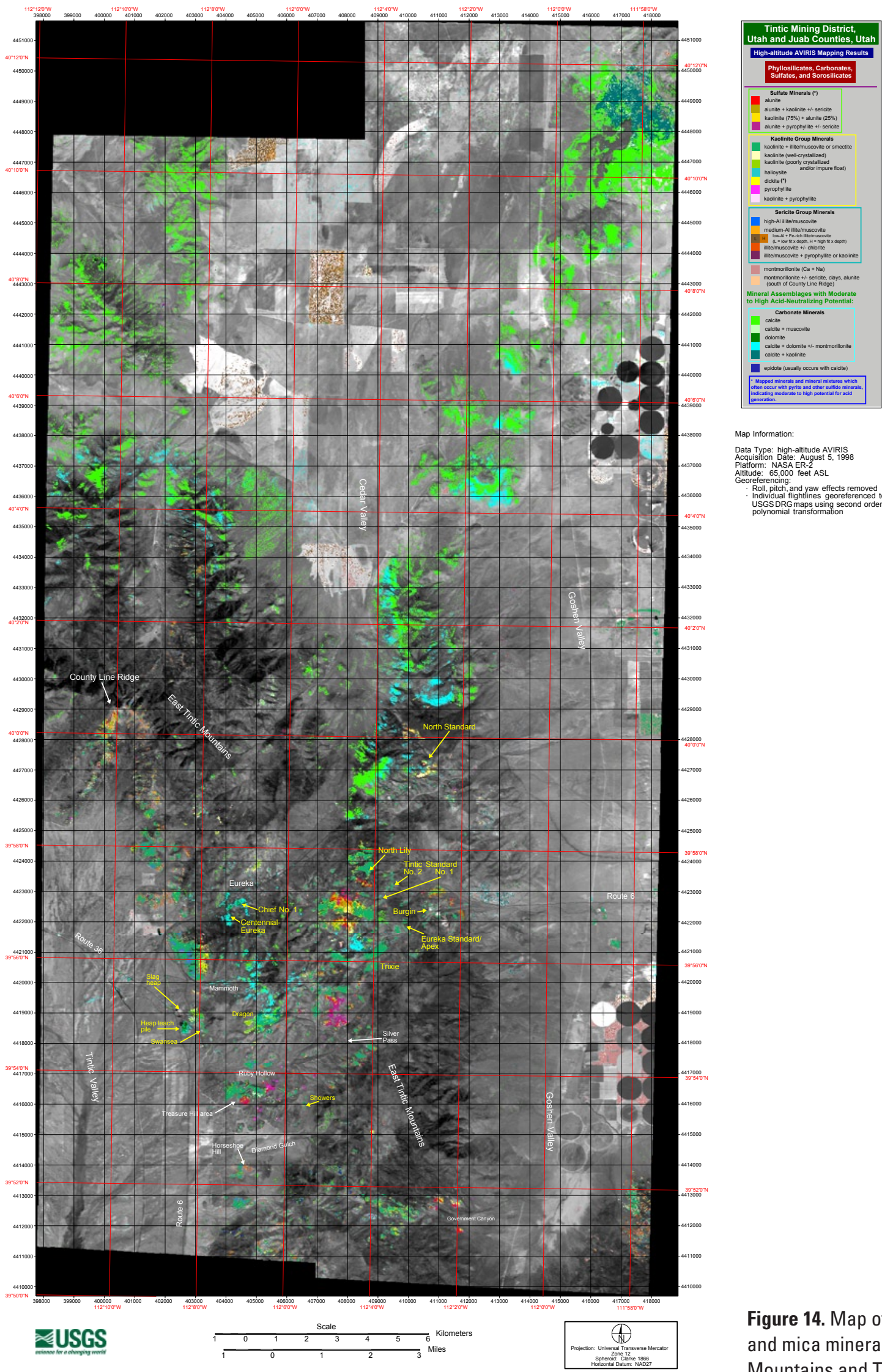

Map Information:

Data Type: high-altitude AVIRIS
Acouistion Date: August 5, 1998

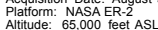

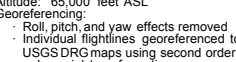

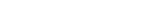

Figure 14. Map of clay, carbonate, sulfate, and mica minerals in the East Tintic Mountains and Tintic mining district, Utah, generated from high-altitude AVIRIS data. View full-resolution file 


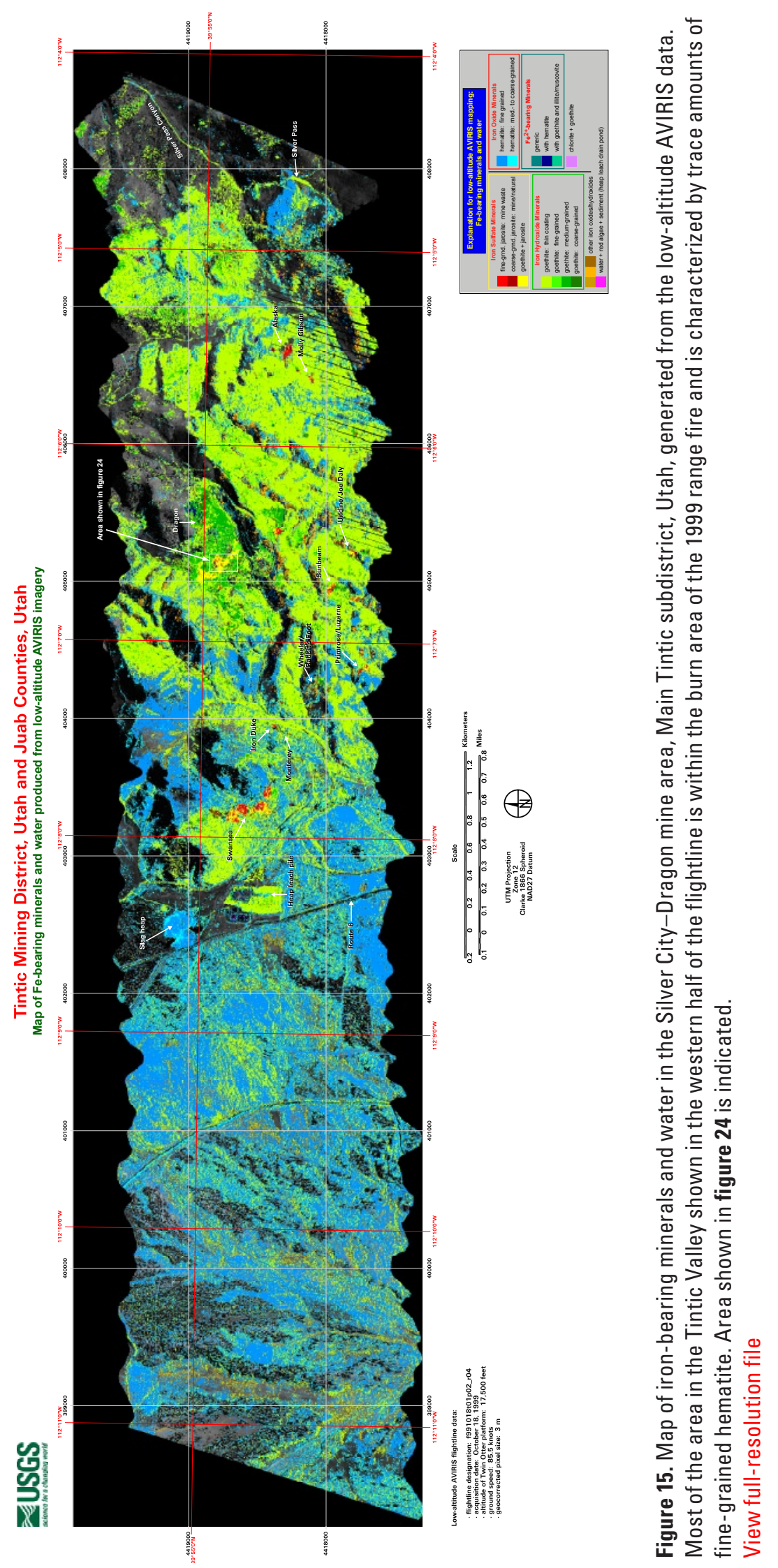




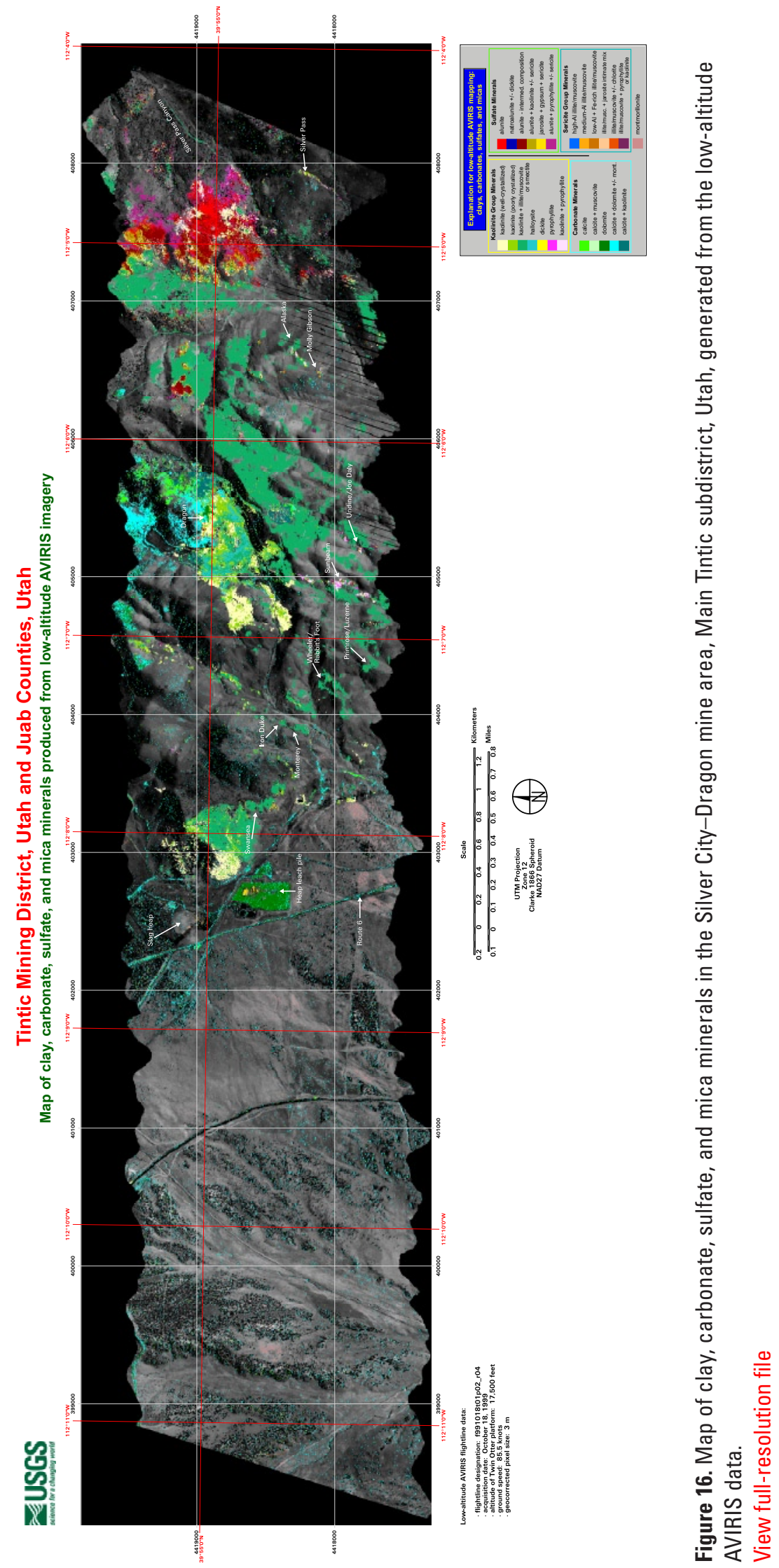




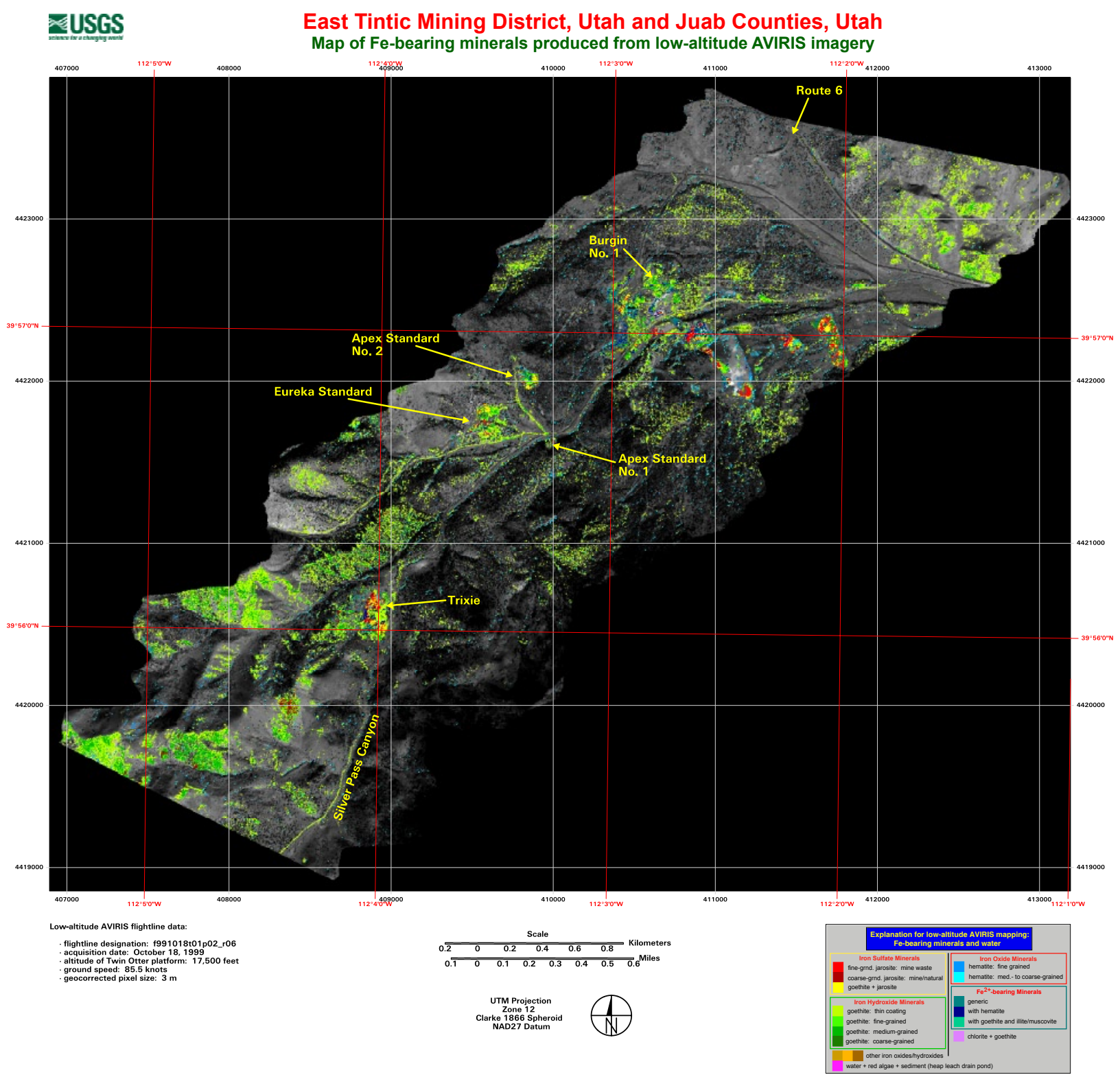

Figure 17. Map of iron-bearing minerals and water in the East Tintic subdistrict, Utah, generated from the low-altitude AVIRIS data.

View full-resolution file 


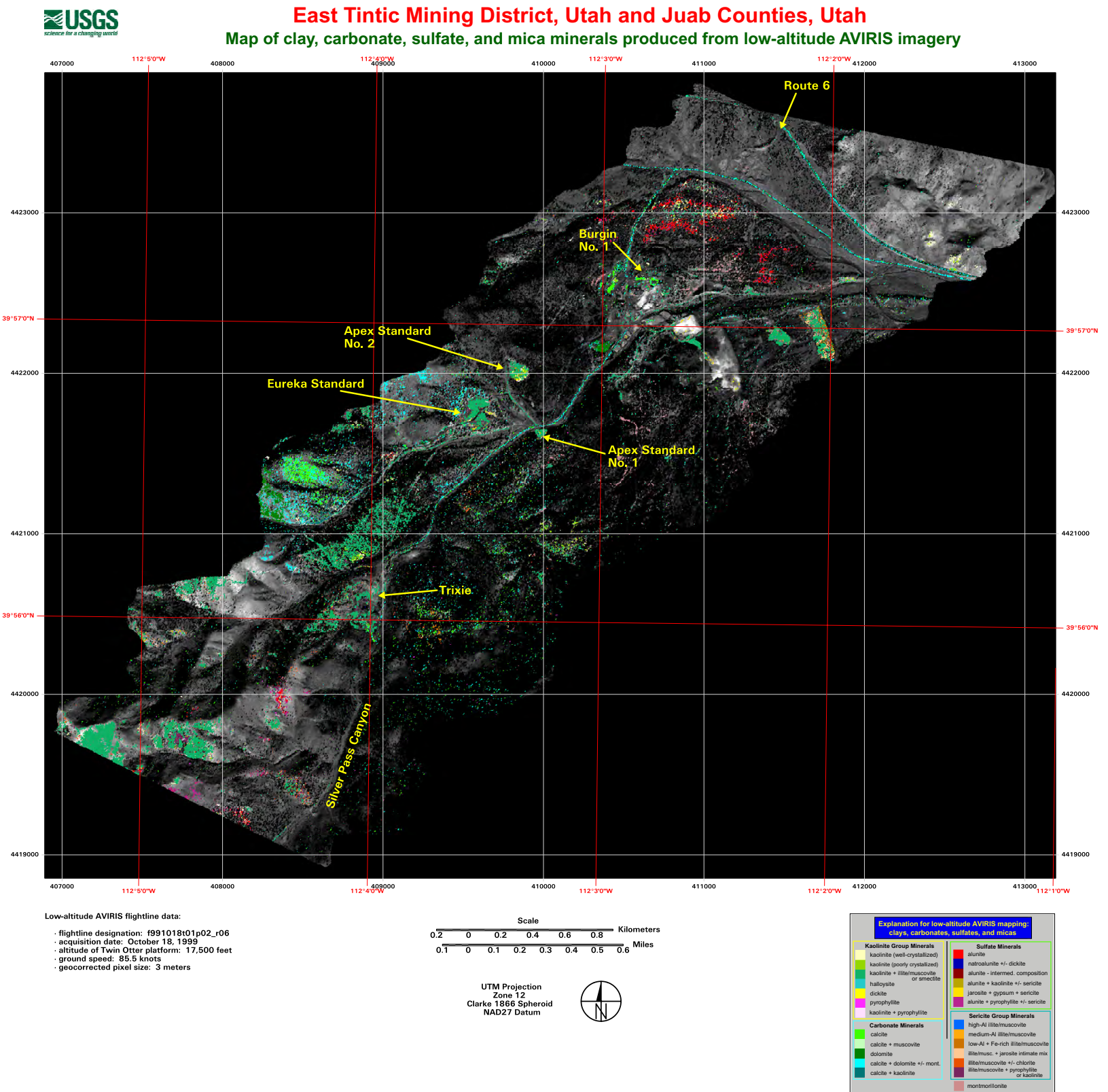

Figure 18. Map of clay, carbonate, sulfate, and mica minerals in the East Tintic subdistrict, Utah, generated from lowaltitude AVIRIS data.

View full-resolution file 
Table 3. Mine sites at which jarosite-bearing waste rock was mapped by using AVIRIS data.

[Asterisks indicate the largest mapped exposures of acid-generating minerals; mine locations shown in figs. 13-19]

\section{Main Tintic Subdistrict (Eureka and Mammoth areas)}

Chief No. 1

Centennial/Eureka

Silver City and Dragon mine area

Swansea $(*)$

Heap leach pile

Monterey

Iron Duke

Cleveland

Dragon (*)

Wheeler/Rabbit's Foot

Primrose/Luzerne

Sunbeam (several dumps along NNE-trending vein)

Undine/Joe Daly (several dumps along NNE-trending vein)

Alaska

Molly Gibson

United Tintic/New State

(shafts located $\sim 0.8 \mathrm{~km}$ WSW of Ruby shaft) $\left(^{*}\right.$ )

Treasure Hill area (south of Ruby Hollow)

Treasure Hill shaft

Tesora (*)

Shoebridge Bonanza

Homestake

(shafts located $0.6 \mathrm{~km} \mathrm{SW}$ of Shoebridge Bonanza)

Showers (*)

Fremont (shafts located $0.75 \mathrm{~km} \mathrm{SSW}$ of Showers)

Joe Bowers

Laclede

West Morning Glory

(shafts located $0.3 \mathrm{~km}$ WNW of Laclede)

\section{East Tintic subdistrict (south of Route 6)}

Burgin (tailings and waste rock) $(*)$

Eureka Standard $(*)$

Apex Standard No. 1

Apex Standard No. 2

Trixie $(*)$

Tintic Standard No. 1 (*)

Tintic Standard No. 2 (*)

North Lily $(*)$

East Tintic subdistrict (north of Route 6)

North Standard clay mineral halloysite $\left(\mathrm{Al}_{2} \mathrm{Si}_{2} \mathrm{O}_{5}(\mathrm{OH})_{4}\right)$, a hydrated form of kaolinite, were discovered at the site. From 1949 to 1972, the halloysite was mined as a filter catalyst for petroleum refining. The main open pit of the mine is at the eastern end of a large mining-disturbed area in which abundant iron-bearing and phyllosilicate minerals were mapped with the AVIRIS data (figs. 21 and 22). Large waste-rock piles are present in the central and western parts of the area.

The Dragon mine is situated along the northern edge of the Silver City Monzonite stock near its contact with Paleozoic metasedimentary rocks such as the Upper Cambrian Ajax Dolomite (fig. 9). The Ajax Dolomite has undergone metasomatic alteration and contact metamorphism related to the intrusion of the stock, resulting in partial recrystallization to form magnesium silicate minerals such as serpentine. The iron and clay deposits at the Dragon mine are localized along the north-northeast-trending Dragon fissure zone that merges with the Iron Blossom ore zone farther to the northeast (figs. 11 and 12). These deposits formed as acidic hydrothermal fluids flowed along fractures and replaced carbonate-bearing sedimentary rocks with the clay mineral endellite $\left(\mathrm{Al}_{2} \mathrm{Si}_{2} \mathrm{O}_{5}(\mathrm{OH})_{4} \cdot 2 \mathrm{H}_{2} \mathrm{O}\right)$, iron oxides, fine-grained pyrite, alunite, manganese oxides, and gibbsite $\left(\mathrm{Al}(\mathrm{OH})_{3}\right)$ (Morris, 1968). Endellite dehydrates to form halloysite upon exposure to the dry desert climate.

Although the waste-rock piles in the central section of the Dragon halloysite mine are large (fig. 23), the concentration of jarosite on the surfaces of these piles is considerably less than is found on waste-rock piles elsewhere in the district at mines from which base and precious metals ores were the primary extracted resource. The map of iron-bearing minerals generated from the high-altitude AVIRIS data (fig. 13) indicates that, at the $17 \mathrm{~m} /$ pixel resolution (ground instantaneous field of view), the waste-rock piles at the Dragon mine are covered with both jarosite and goethite (an "areal mixture" indicated in fig. 13 as "goethite + jarosite"), whereas the surfaces of most of the other waste-rock piles listed in table 3 are mainly composed of jarosite. However, the low-altitude AVIRIS map of iron-bearing minerals of the mine (figs. 15, 22, and 24A) resolves small patches of highly jarositic rocks within a large area dominated by the jarosite + goethite areal mixture. For the Dragon mine's waste-rock piles, AVIRIS spectra (figs. 24B and 25) show that both the pixels spectrally identified as jarosite and the pixels spectrally identified as a jarosite + goethite areal mixture have pronounced absorption features due to jarosite (for example, at $0.43 \mu \mathrm{m}$ ), indicating substantial amounts of jarosite at the surface. Field and XRD studies found that pyrite-bearing waste rock is abundant in the areas of the piles where jarosite was mapped with the AVIRIS data (appendix table A1, sample TN00-17B). Despite having only moderate concentrations of jarosite when compared to other waste-rock piles in the Tintic district, the large size of the pyrite- and (or) jarosite-bearing wasterock piles at the Dragon mine makes them an important potential source of acid generation. 


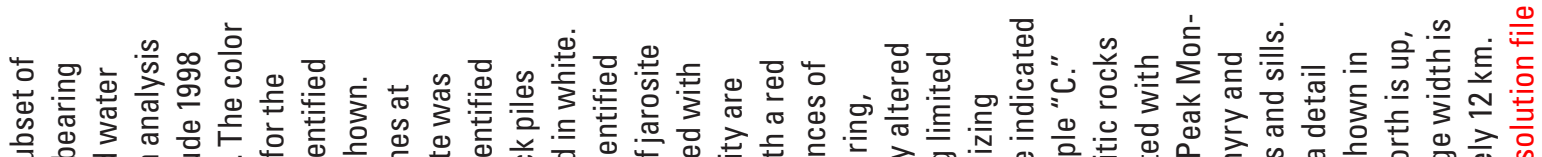

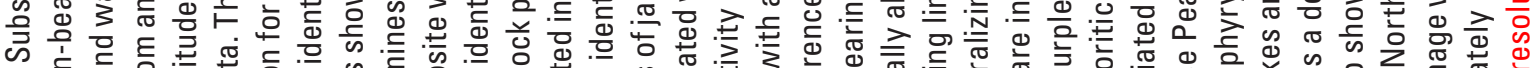

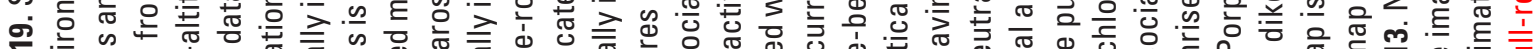

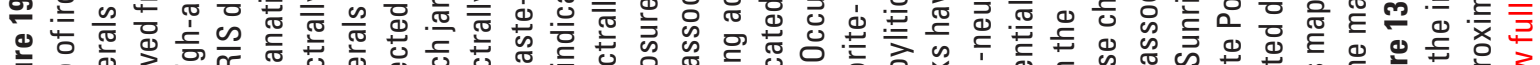

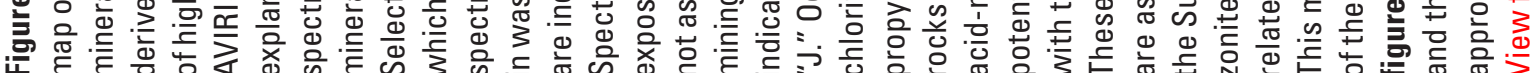
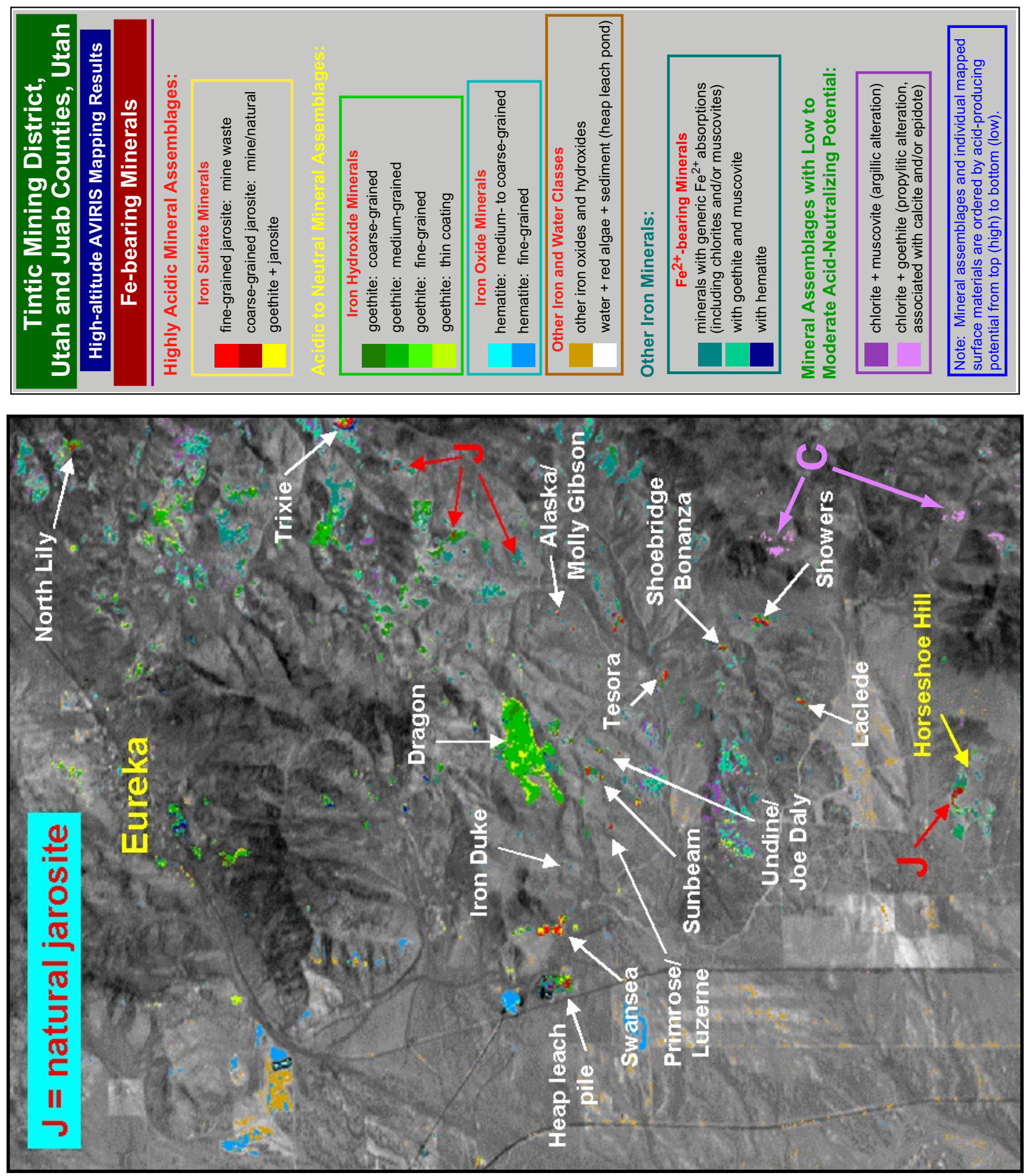
Figure 25 also shows that the $\mathrm{Fe}-\mathrm{OH}$ absorption feature of jarosite in the short-wave infrared (SWIR) spectral region near $2.27 \mu \mathrm{m}$ is not present in the AVIRIS spectra whose characteristics in the visible (VIS) and near-infrared (NIR) regions indicate the existence of jarosite. Figure $\mathbf{1 6}$ shows that no pixels in the Dragon mine area were identified as jarosite bearing by using the SWIR data because the $2.27 \mu \mathrm{m}$ feature was not detected, although abundant jarosite was identified by using the VIS and NIR spectral regions of AVIRIS (fig. 15). The reason is that phyllosilicate minerals, when present in abundance, tend to dominate the SWIR and mask the spectral features of jarosite in that wavelength region while the strong crystal field absorptions in the VIS and NIR related to ferric iron remain unobscured. Therefore, the VIS and NIR data are preferable to the SWIR data for the remote identification of jarosite (and other iron-bearing minerals) using spectroscopic methods.

Extensive exposures of rocks with thin coatings of goethite were mapped with the 1999 low-altitude AVIRIS data in and around the Dragon mine, especially in areas underlain by argillically and (or) pyritically altered zones of the Swansea Quartz Monzonite and Silver City Monzonite stocks (refer to fig. 9 for locations of stocks and figs. $\mathbf{1 6}$ and $\mathbf{1 8}$ to locate areas altered to alunite, kaolinite, and [or] kaolinite + illite/muscovite). Rocks with goethite coatings were also spectrally identified in drainages downstream from the Dragon mine, but these rocks may be derived from the surrounding altered intrusive rocks and not exclusively from downstream movement of pyrite- and jarosite-bearing rocks and (or) acidic solutions from the Dragon mine. Most of the large exposures of goethite-coated rocks outside of the Dragon mine were not mapped with the 1998 high-altitude AVIRIS data, probably because these areas were masked with rangeland vegetation when the data were acquired. A large range fire occurred in June 1999 (4 months before the low-altitude AVIRIS data were acquired) that denuded the area surrounding the Dragon mine of vegetation. The burn scar from this fire is visible in reddish hues in figure 26, a Landsat 7 ETM+ color composite of the East Tintic Mountains. The fire likely exposed the altered, goethite-coated rocks of the stocks and surrounding metasomatically altered sedimentary formations. The fire also burned and denuded large areas of the Tintic Valley to the west of the Silver City-Dragon mine area. Extensive exposures of fine-grained hematite in low abundance were spectrally identified in these burned areas (fig. 15); this hematite was likely created by the oxidation of iron-bearing minerals in the sandy alluvial

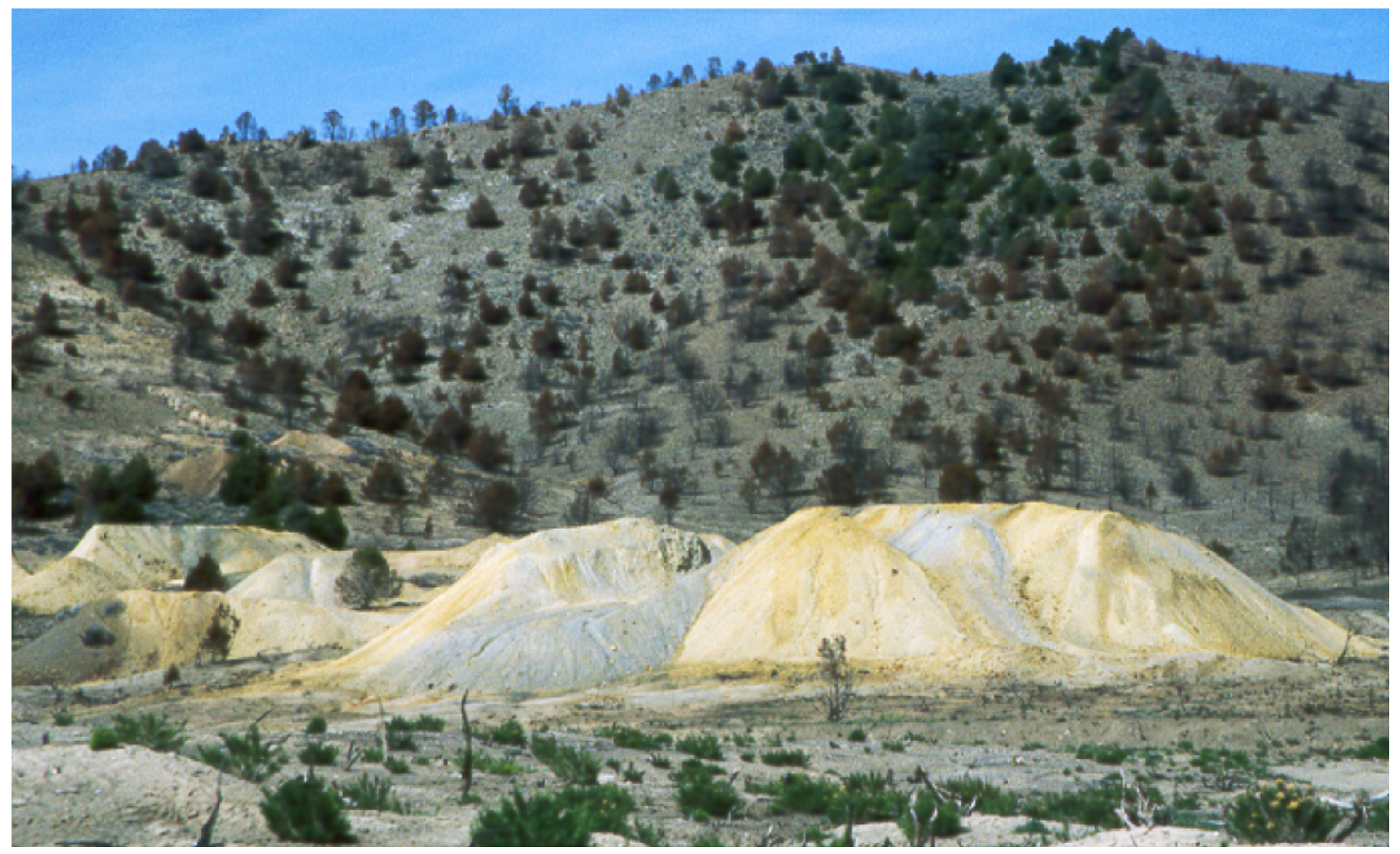

Figure 20. Waste-rock piles with yellowish and yellow-green coatings of jarosite at the Swansea mine site (location shown in figs. 13-16) near Silver City. These piles, which reach $>6 \mathrm{~m}$ in height, are typical of mine waste in the Tintic mining district. Piñon and juniper trees and bushes that burned during the 1999 range fire are visible in the background on hills underlain by the Swansea Quartz Monzonite and Silver City Monzonite.

View full-resolution file 
Table 4. Total production and average ore grades of several mines near town of Eureka, Utah.

\begin{tabular}{|c|c|c|c|c|c|c|c|}
\hline \multirow[t]{2}{*}{ Mine } & \multirow{2}{*}{$\begin{array}{c}\text { Total } \\
\text { production } \\
\text { (tons) }\end{array}$} & \multicolumn{6}{|c|}{ Average ore grade } \\
\hline & & $\begin{array}{c}\mathrm{Au} \\
\text { (oz.) }\end{array}$ & $\begin{array}{c}\mathrm{Ag} \\
\text { (oz.) }\end{array}$ & $\begin{array}{c}\mathrm{Cu} \\
(\%)\end{array}$ & $\begin{array}{l}\mathrm{Pb} \\
(\%)\end{array}$ & $\begin{array}{l}\mathrm{Zn} \\
(\%)\end{array}$ & $\mathrm{Cu} / \mathrm{Pb}$ \\
\hline Chief No. 1 & $3,500,000$ & 0.1 & 15.5 & 0.3 & 6 & 2.3 & 0.05 \\
\hline Centennial/Eureka & $1,422,402$ & 0.4 & 12.6 & 2.4 & 0.6 & -- & 3.92 \\
\hline Gemini & 298,052 & -- & 31.1 & 0.3 & 10.5 & 0.1 & 0.028 \\
\hline Eureka Hill & 116,450 & 0.7 & 15 & 0.6 & 5.6 & -- & 0.119 \\
\hline Snowflake & 225 & -- & 6.9 & 4.4 & -- & -- & -- \\
\hline Eagle and Bluebell & 668,017 & 0.1 & 11.7 & 0.2 & 7.5 & -- & 0.022 \\
\hline
\end{tabular}

soils by the heat from the fire. In forested areas that have undergone intense, high-temperature burns, fine-grained coatings of hematite with weak ferric iron absorptions have been observed on rocks and soils normally free of ferric iron coatings (Kokaly and others, 2002). Hematite was also spectrally identified in a heap of smelter slag located $\approx 1 \mathrm{~km}$ northwest of the Swansea waste-rock piles (figs. 13 and 15).

In addition to halloysite clay, kaolinite + muscovite mixtures were mapped with the AVIRIS data in the central and eastern parts of the Dragon mine (figs. 14 and 16). Rocks and soils spectrally identified as kaolinite + muscovite mixtures within and just south of the mine are most likely derived from argillically and pyritically altered monzonite from the Silver City stock. Relatively pure kaolinite spectrally dominates the westernmost waste-rock piles, most of which were a spectral match to well-crystallized kaolinite. Several small areas containing alunite, mixtures of alunite + kaolinite, and well-crystallized kaolinite were spectrally identified on the northern edge of the pit near the Dragon fissure (on the west end of the northern pit wall) and within the waste-rock piles. On the pit wall in the northeast corner of the mine, upstream (northeast) from most of the mining activity, large exposures of carbonate-bearing rocks were spectrally identified, including calcite, dolomite, mixtures of the two, and calcite + kaolinite. These minerals are associated with the metasomatically altered Paleozoic carbonate rocks. Because these rocks are located upstream from the pyrite-bearing waste rock, their ANP will probably not have a large effect on any acidic solutions generated in the mine itself.

Few carbonate-bearing rocks or soils were spectrally identified downstream from the Dragon mine area with the high-altitude AVIRIS data (fig. 14). From the low-altitude AVIRIS data, some soils containing calcite and dolomite were identified along roads in the Silver City area immediately southeast of the Swansea waste-rock piles and within the Silver City Monzonite just east of the contact with the Swansea Quartz Monzonite (fig. 16). These carbonate-bearing soils have not been field checked, but are probably related to eolian dusts, road metal, or propylitic alteration of the igneous rocks that underlie this area. Few OH-bearing minerals (for example, clays, sulfates, micas) were spectrally identified within the drainages downstream from the Dragon mine. Therefore, it appears as if little, if any, natural ANP exists downstream from the mine. Two important factors, however, reduce the potential for significant metal loading of soils and ground or surface water down-gradient from the waste-rock piles at the Dragon mine. First, the generally low amounts of annual precipitation in the area (on average, $35 \mathrm{~cm} / \mathrm{yr}$, Morris and Mogensen, 1978) reduce the overall rate and frequency of downstream flow of potentially metal bearing solutions from the mine. Second, geologic studies of the halloysite clay deposits at the Dragon mine have indicated that the widespread argillic and pyritic alteration of the sedimentary and intrusive rocks in the area occurred before the introduction of base and precious metals in the district and the hydrothermal solutions responsible for this alteration were in general barren of metals (Morris, 1968). The alteration events responsible for the deposits of hematite and halloysite clay are generally thought to be associated with the mid-barren (argillization) and late-barren (pyritization, calcification, and silicification) stages of alteration in the district (Lovering, 1949). On the basis of a geological understanding of the clay deposits at the Dragon mine, the waste rock associated with the deposits can be assumed to have relatively low concentrations of heavy metals.

\section{Unmined Mineralized Rocks with Acid-Producing Potential (APP)}

Unmined areas underlain by altered, mineralized rock can be clearly identified on AVIRIS-derived maps of minerals having vibrational absorptions in the 1.4- to $2.5-\mu \mathrm{m}$ spectral region (fig. 27). Altered rocks in these unmined areas are characterized by alunite, clay minerals, and micas associated with intense argillization, sericitization, and local pyritization. Prominent altered areas include alunitic zones near Silver Pass, Big Hill, Treasure Hill, and the kaolinized Swansea Quartz Monzonite.

The mineral map generated from the high-altitude 1998 AVIRIS data (figs. 14 and 27) shows a large area of alunite + pyrophyllite surrounded by pixels of alunite, pyrophyllite, and alunite + kaolinite just north of Silver Pass. The map of this area generated from the low-altitude 1999 


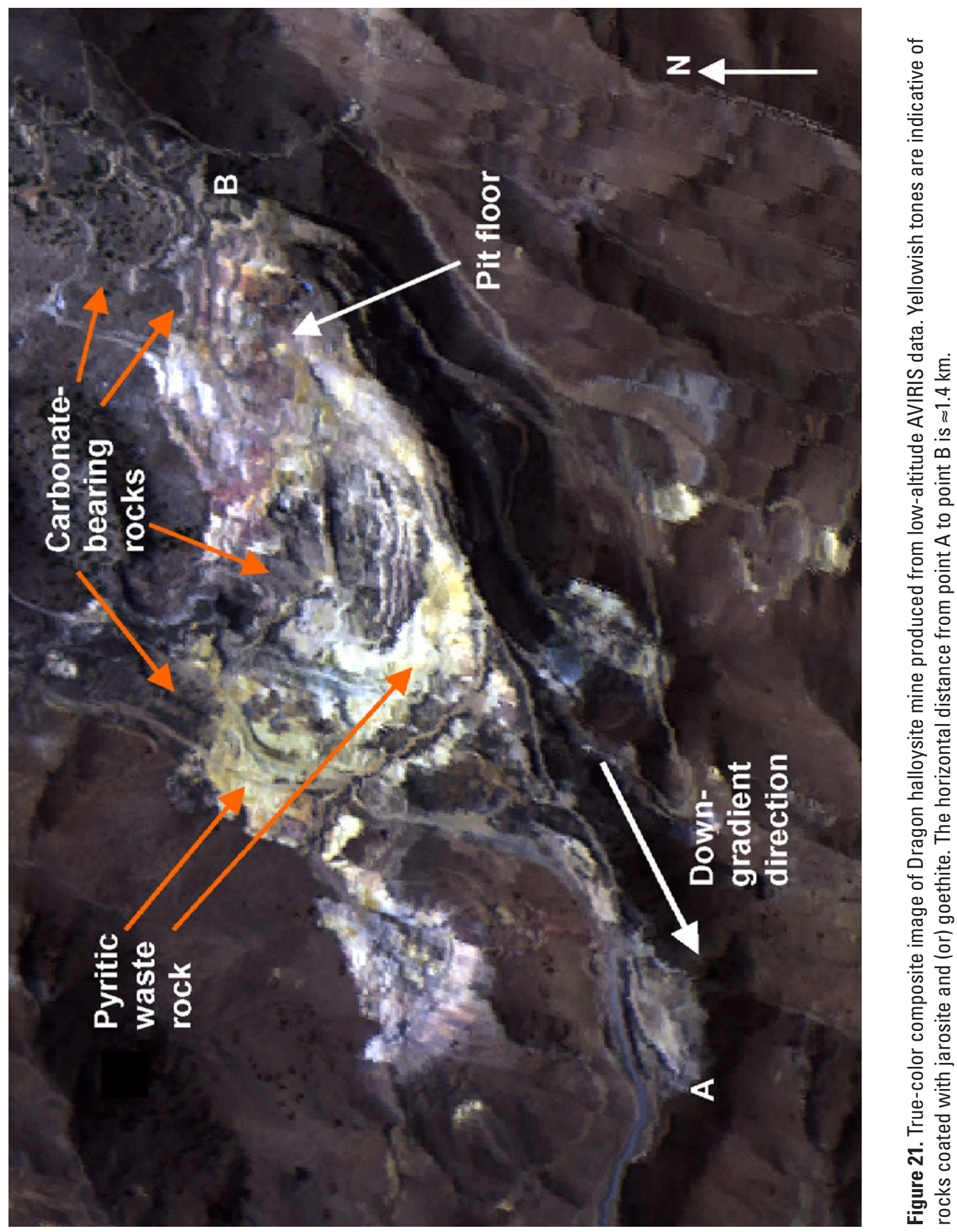



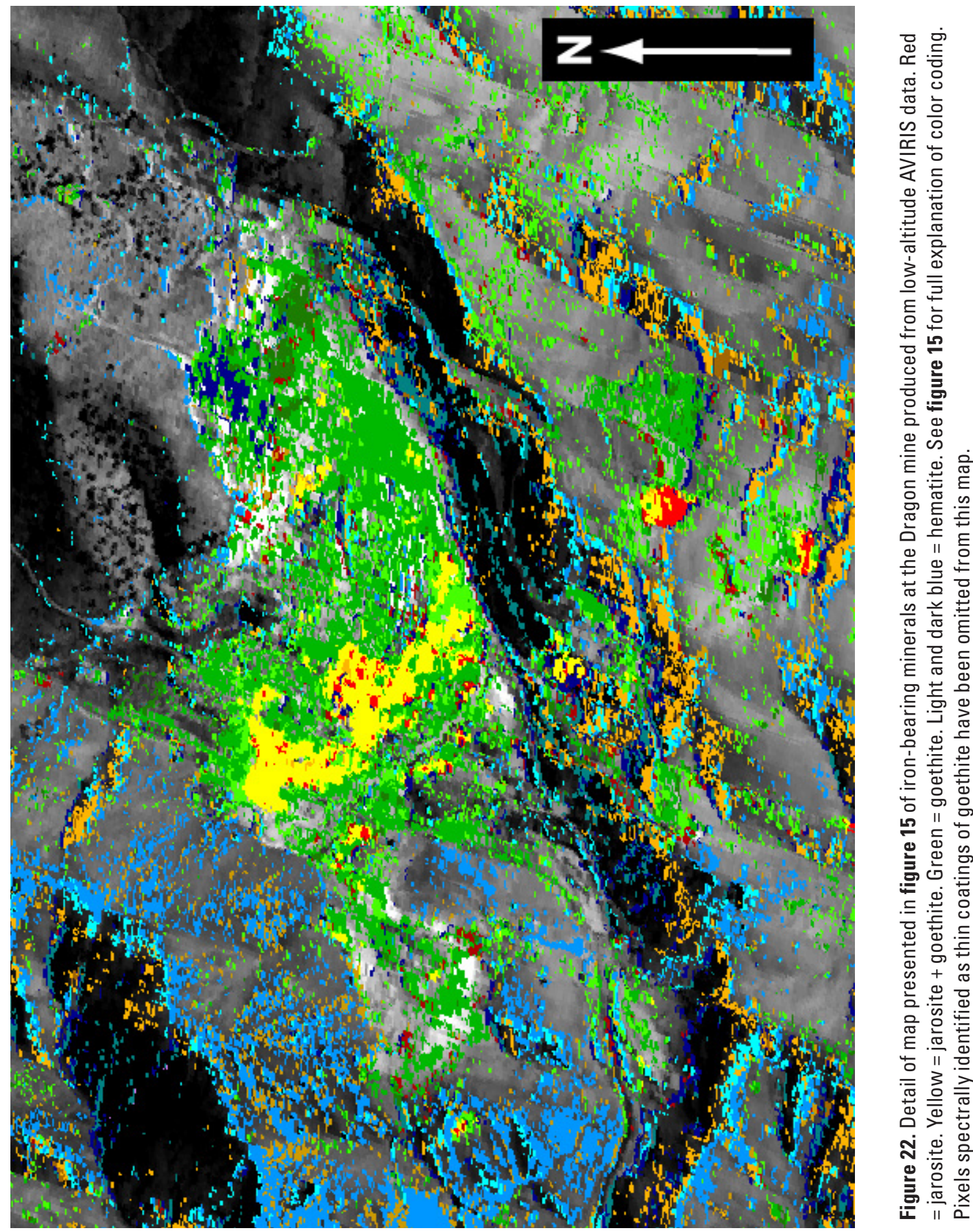


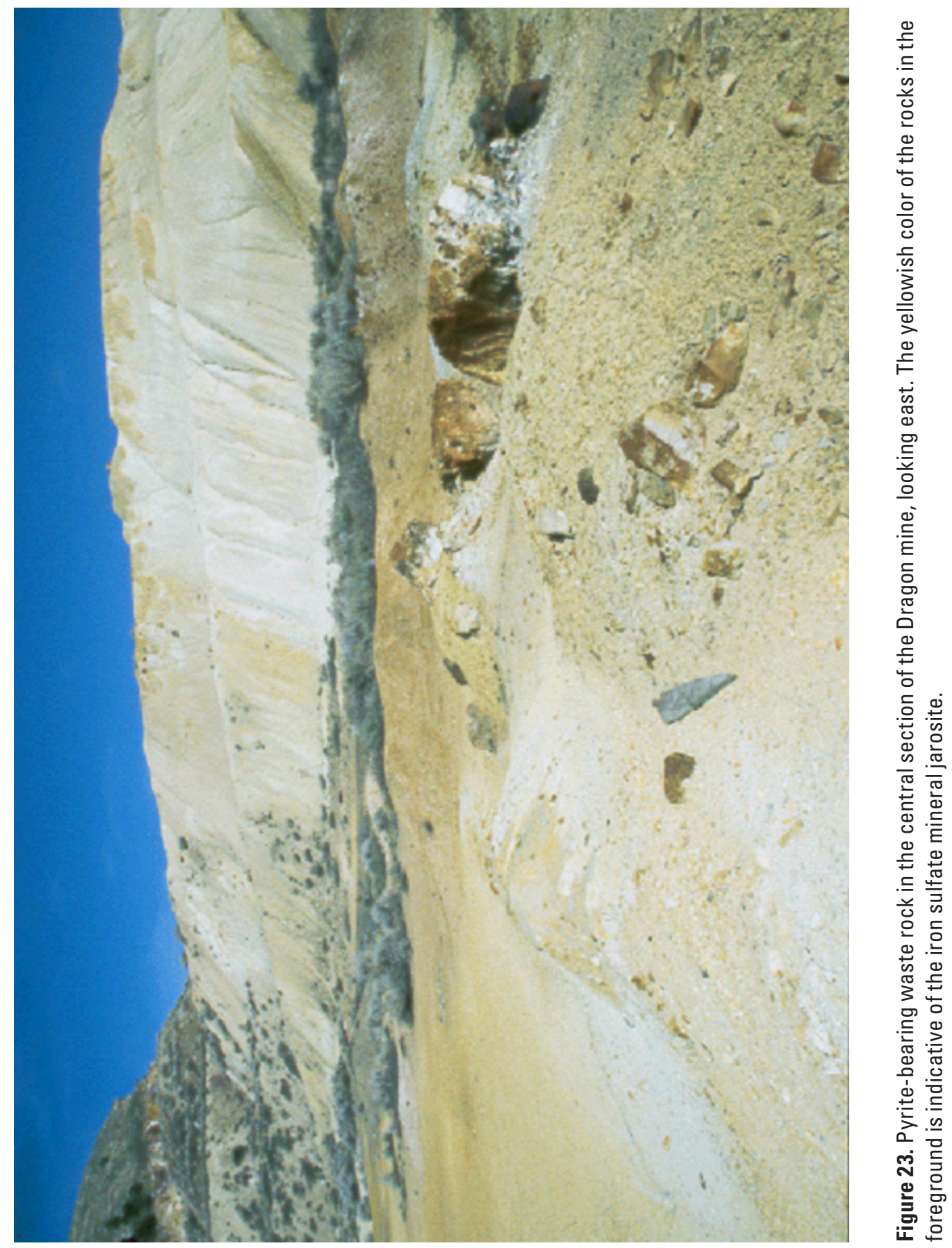


A
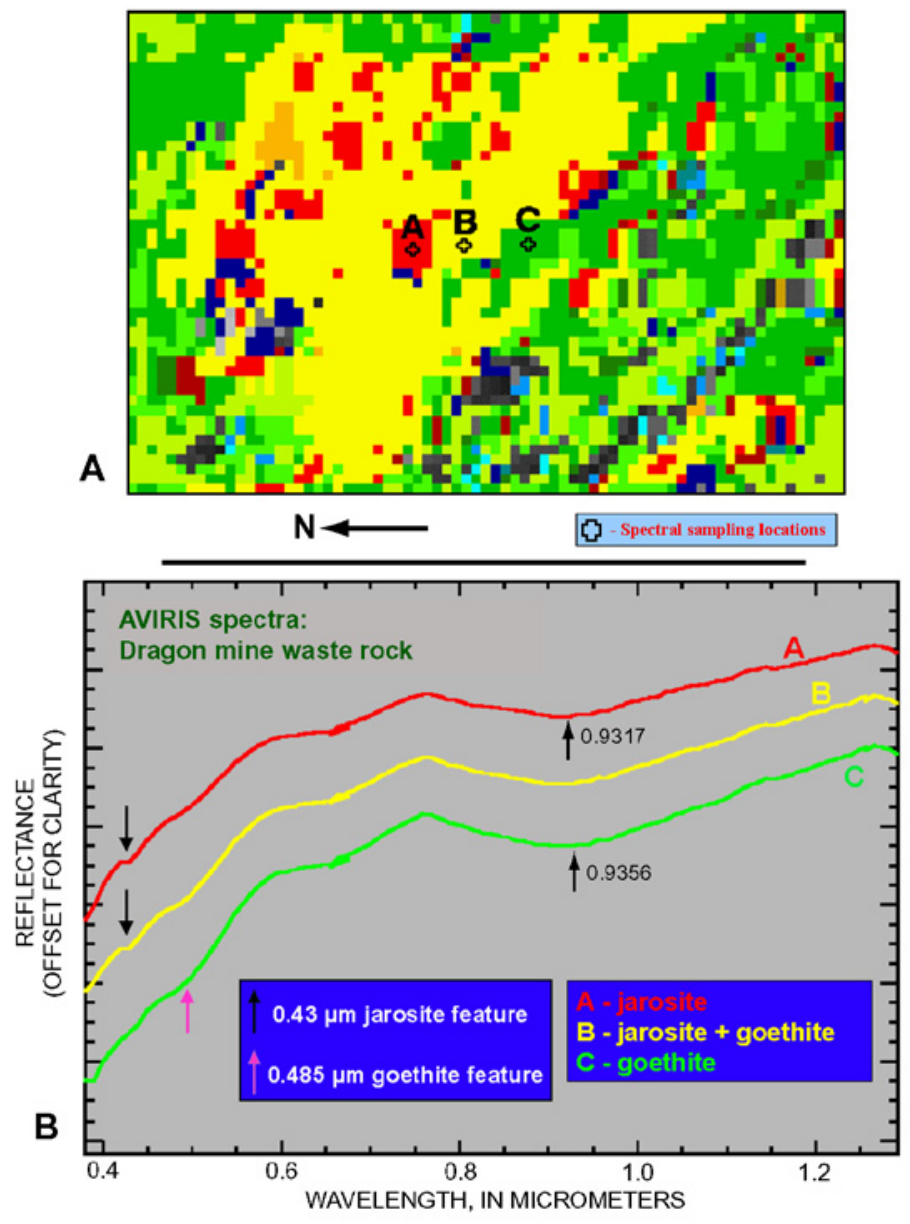

Figure 24. Spectral minitransect across waste-rock piles in the central section of the Dragon mine. (A) Spectral sampling locations on map of iron-bearing minerals derived from 1999 low-altitude AVIRIS data (refer to fig. $\mathbf{1 5}$ for location of sampling area). (B) Average AVIRIS spectra sampled from these locations. Spectra shown are averages of 16 AVIRIS pixels. Continuum-removed band centers for the ferric iron absorptions near $0.93 \mu \mathrm{m}$ due to crystal field effects are indicated. For comparison, the continuum-removed band center is $0.9190 \mu \mathrm{m}$ for reference jarosite GDS99 and $0.9475 \mu \mathrm{m}$ for coarse-grained goethite WS222. The absorption occurs at longer wavelengths for goethite than for jarosite. View full-resolution file

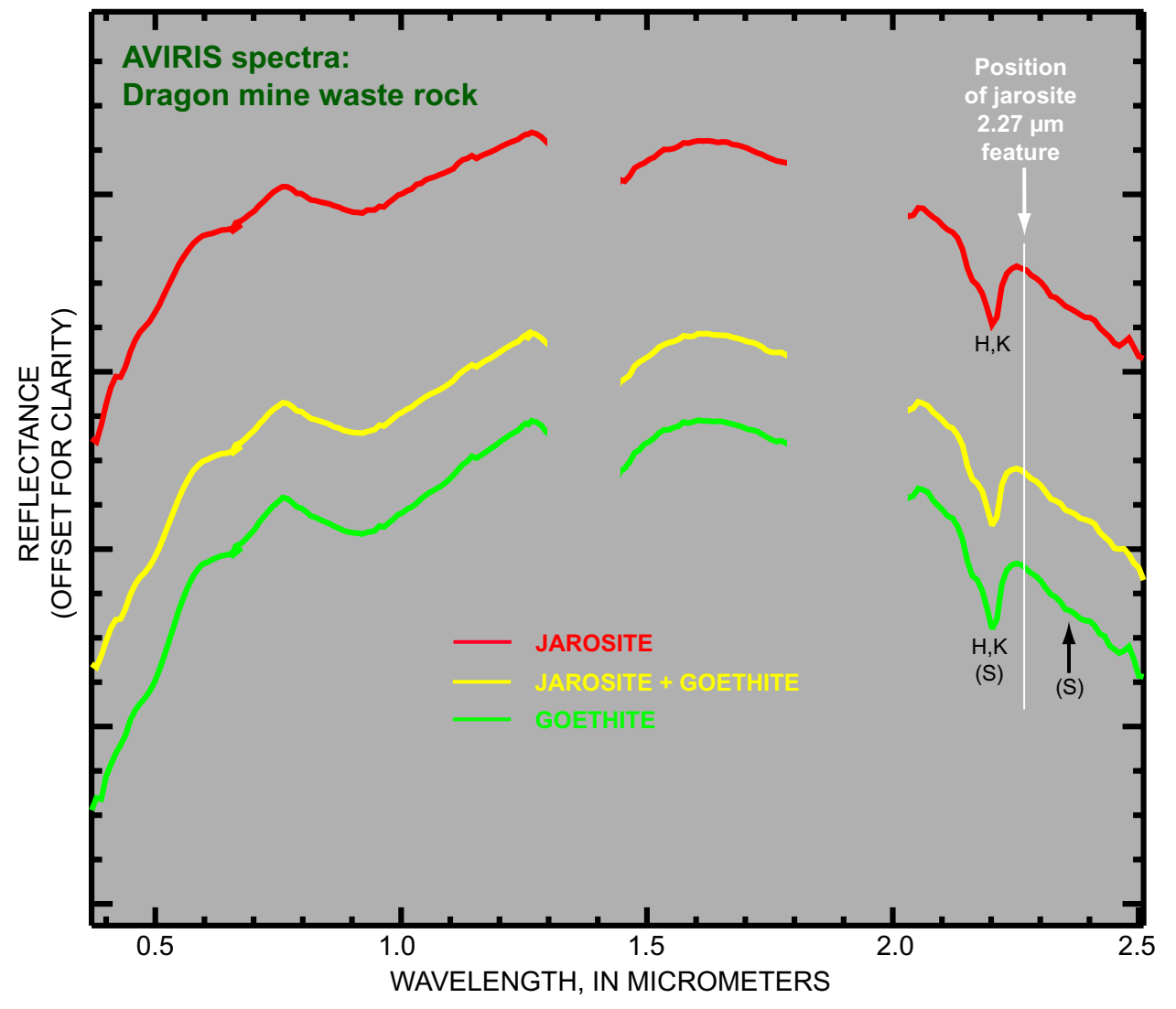

Figure 25. Average low-altitude AVIRIS spectra from minitransect across waste-rock piles at the Dragon mine shown in figures $\mathbf{2 3}$ and $\mathbf{2 4}$. Here, the spectra are shown across the full AVIRIS spectral range. Note that the $\mathrm{Fe}-\mathrm{OH}$ absorption feature at $2.27 \mu \mathrm{m}$ characteristic of jarosite is not present in these spectra because of the spectral dominance of phyllosilicates (clays and micas) at the AVIRIS pixel scale. $\mathrm{H}, \mathrm{K}=$ halloysite \pm kaolinite. $(\mathrm{S})=$ sericite (illite or muscovite). 


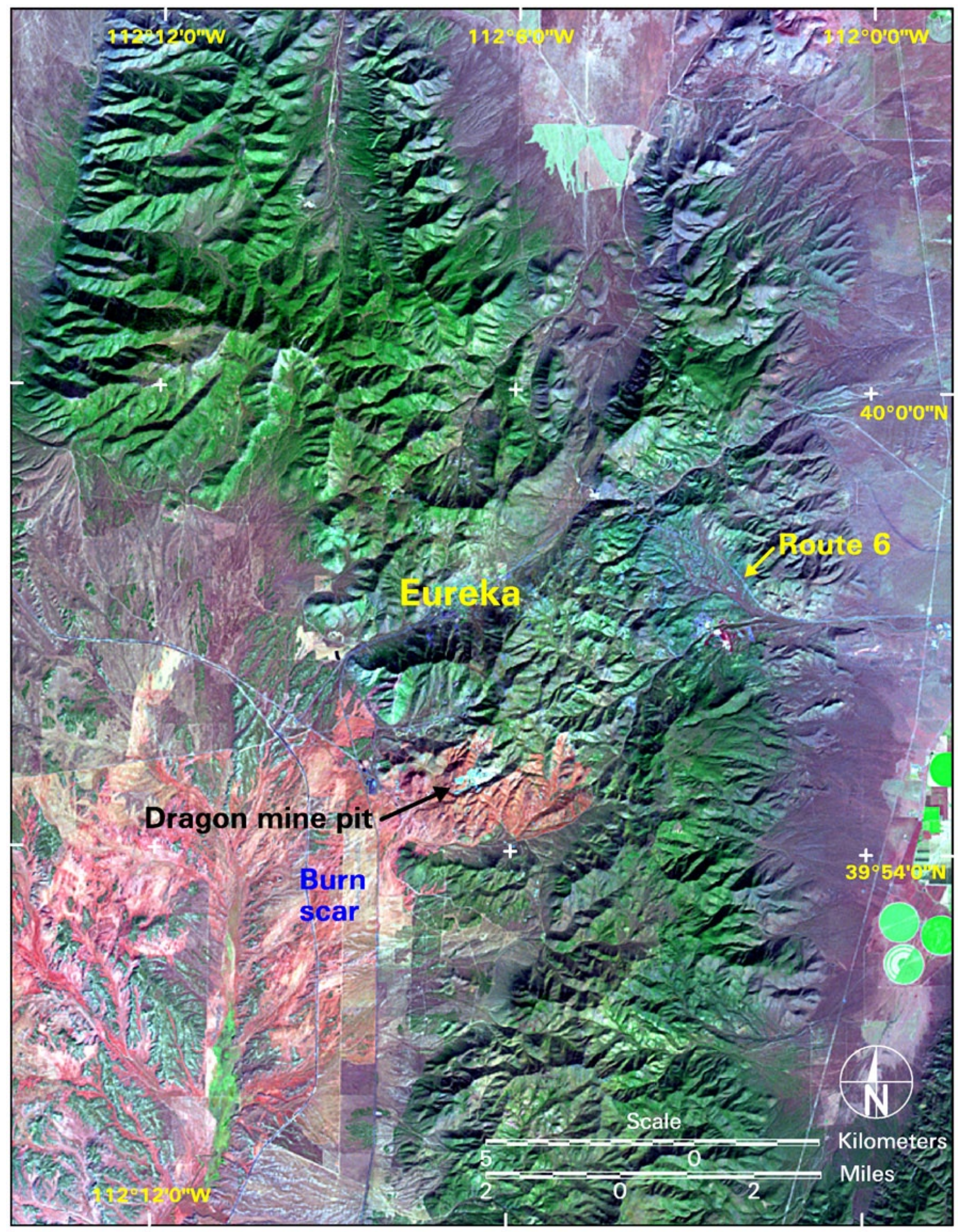


AVIRIS data (fig. 16) that were acquired after the range fire shows that the alteration zone has a core of alunite that grades outward toward the west into zones of intermediate-composition alunite, alunite + kaolinite, and kaolinite. Figure $\mathbf{1 6}$ also shows that zones of pyrophyllite and alunite + pyrophyllite border the alunitic core on the southeast and north. Intimate mixtures of alunite, pyrophyllite, and kaolinite were verified by XRD in a sample collected from the southeastern edge of the alteration zone alongside the road in Silver Pass Canyon (appendix table A1, sample TN00-8). Comparison of the high- and low-altitude AVIRIS mapping results over the Silver Pass area suggests that a smaller exposure of intimate mixtures of alunite and pyrophyllite is actually present than was mapped with the high-altitude AVIRIS data. This difference in the spectral mapping could be due to a partial misidentification of alunite as mixtures of alunite + pyrophyllite because of lichen and (or) dry grasses present on the surface before the range fire, an error that was recognized in the Antelope Range area of the Marysvale volcanic field (see appendix table A3, sample MV99-6-21).

Altered and mineralized rocks, including the ore deposits, occur along faults and fractures, usually within several kilometers of exposures of intrusive igneous rocks (see fig. 9 for principal locations of igneous rocks in the district). These fractured rocks may serve as conduits for the transport and recharge of modern ground water. Figure 28 shows the mineral maps derived from analysis of the high-altitude AVIRIS data overlaid with faults and fractures digitized from published maps (Morris and Mogensen, 1978). It is quite apparent that the waste-rock piles from many mines, especially those associated with ore deposits in replacement veins and fissure veins in the vicinity of the Silver City stock, are situated along faults and fractures. Figure 28 also shows that many argillically altered areas in which alunite, clays, and micas were spectrally identified are also oriented along fault zones. The vein deposits in the vicinity of Treasure Hill (for example, Showers, Shoebridge Bonanza, Tesora, and Laclede, figs. 9 and 19) are strongly localized along three parallel, northeast-trending fracture zones that cut propylitized andesitic volcanic rocks. These propylitized rocks are locally abundant in calcite and sericite and may offer some ANP (fig. 14). Dickite and pyrite were found in an undisturbed outcropping of a silicified vein system immediately south-southwest of the Showers mine. This vein system was economically mineralized in silver, copper, and lead at depth (Cook, 1957). Most of the metal production from the Treasure Hill area was silver or copper, with lesser gold and lead-zinc from the southern and eastern workings (Krahulec, 1996). In the East Tintic subdistrict (the location of the Trixie, North Lily, Tintic Standard, Eureka Standard,

Figure 26 (preceding page). Landsat $7 \mathrm{ETM}+$ color composite (741/RGB) of the East Tintic Mountains, Utah. Green vegetation is shown in green tones. A burn scar from a range fire that occurred in June 1999 is visible in reddish hues on the west flank of the range and in the Tintic Valley. Scale bars are shown at lower right. View full-resolution file and Burgin mines), ore deposits are located along fault zones adjacent to, but not within, areas of intense argillic alteration. As pyrite, jarosite, and alunite are locally present in high concentrations in the altered rocks of the Tintic district (as is typical of magmatic hydrothermal acid-sulfate alteration systems), the premining $\mathrm{pH}$ baselines of local watersheds are likely to be significantly more acidic than those in unmineralized parts of the East Tintic Mountains.

Published maps of hydrothermal alteration in the East Tintic subdistrict (Lovering, 1960) indicate large exposures of altered rock, mainly the Packard Quartz Latite, which contain fine-grained disseminated pyrite. The AVIRIS-derived mineral maps show that these rocks are characterized mainly by goethite on the surface (figs. 13 and 17). As an example, one of these outcrops of unmined, pyrite-bearing, altered rock that is coated with goethite is located $\approx 1.5 \mathrm{~km}$ east-northeast of the Burgin mine, immediately to the north of Route 6 . Several pixels of jarosite were also spectrally identified in this area within broad zones of goethite (fig. 17). Pyritically altered rocks with similar goethite coatings were also identified in the Silver Pass area, and some of the goethite coatings in and around the Silver City Monzonite stock are also likely to be associated with weakly pyritized rock. The rocks with goethite coatings are in near-equilibrium with atmospheric conditions and thus are likely to produce solutions having mildly acidic to near-neutral $\mathrm{pH}$. Runoff draining nearby unaltered rocks not having goethite coatings would be expected to have a higher $\mathrm{pH}$.

Several other occurrences of unmined, nonanthropogenic jarosite were mapped with the AVIRIS data in areas underlain by altered rock that has been argillized, pyritized, and (or) silicified. These occurrences of jarosite are shown on the maps of iron-bearing minerals generated from the high-altitude and low-altitude AVIRIS data and are marked with a red "J" in figure 19. These jarositic areas are underlain by altered volcanic rocks including the alunite-bearing rocks and silicified breccia zones located between Silver Pass and the Trixie mine (figs. 13-18) and by sericite-bearing rocks on Horseshoe Hill (figs. 19 and 27). XRD analysis of rocks from these areas confirmed the presence of jarosite (appendix table A1). The alteration of the rock exposed on Horseshoe Hill and on the low hill $1.5 \mathrm{~km}$ to the south is most likely phyllic, or quartz-sericite-pyrite (QSP), alteration associated with the unmined, subsurface Southwest Tintic (SWT) porphyry copper system located $1-3 \mathrm{~km}$ southwest of Horseshoe Hill (figs. 9 and 27, and Krahulec, 1996). Through the use of the AVIRIS data, the Tetracorder-based spectral mapping was able to differentiate these exposures of natural, nonanthropogenic jarosite from jarosite in waste-rock piles. Jarosite not associated with mining activity was spectrally identified exclusively as coarse-grained jarosite (see map explanations), whereas jarosite-bearing waste rock at mine sites was spectrally identified mainly as "fine-grained" jarosite. Figure 29 shows the spectral variation between XRD-confirmed jarosites sampled from pyrite-bearing waste rock in the Dragon mine (in blue) and from unmined, altered rocks from the Silver Pass alteration zone (in red). The 0.43- and 2.27- $\mu \mathrm{m}$ absorption features that are diagnostic for jarosite are evident 


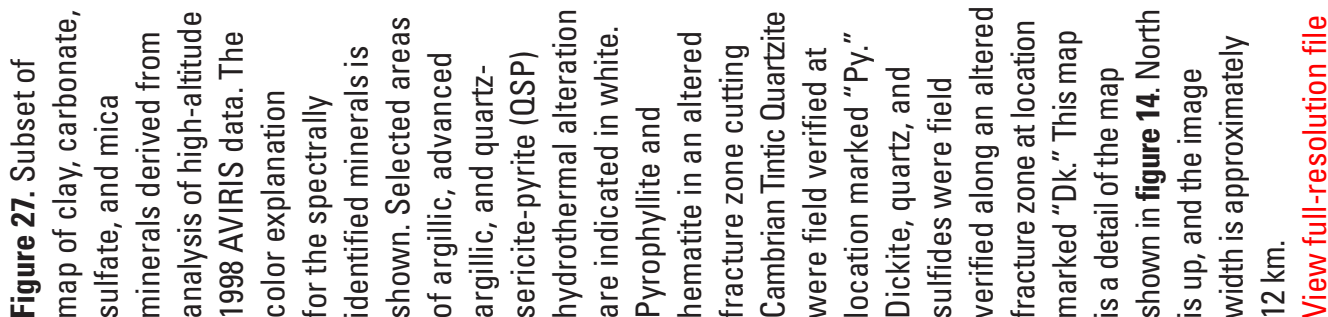
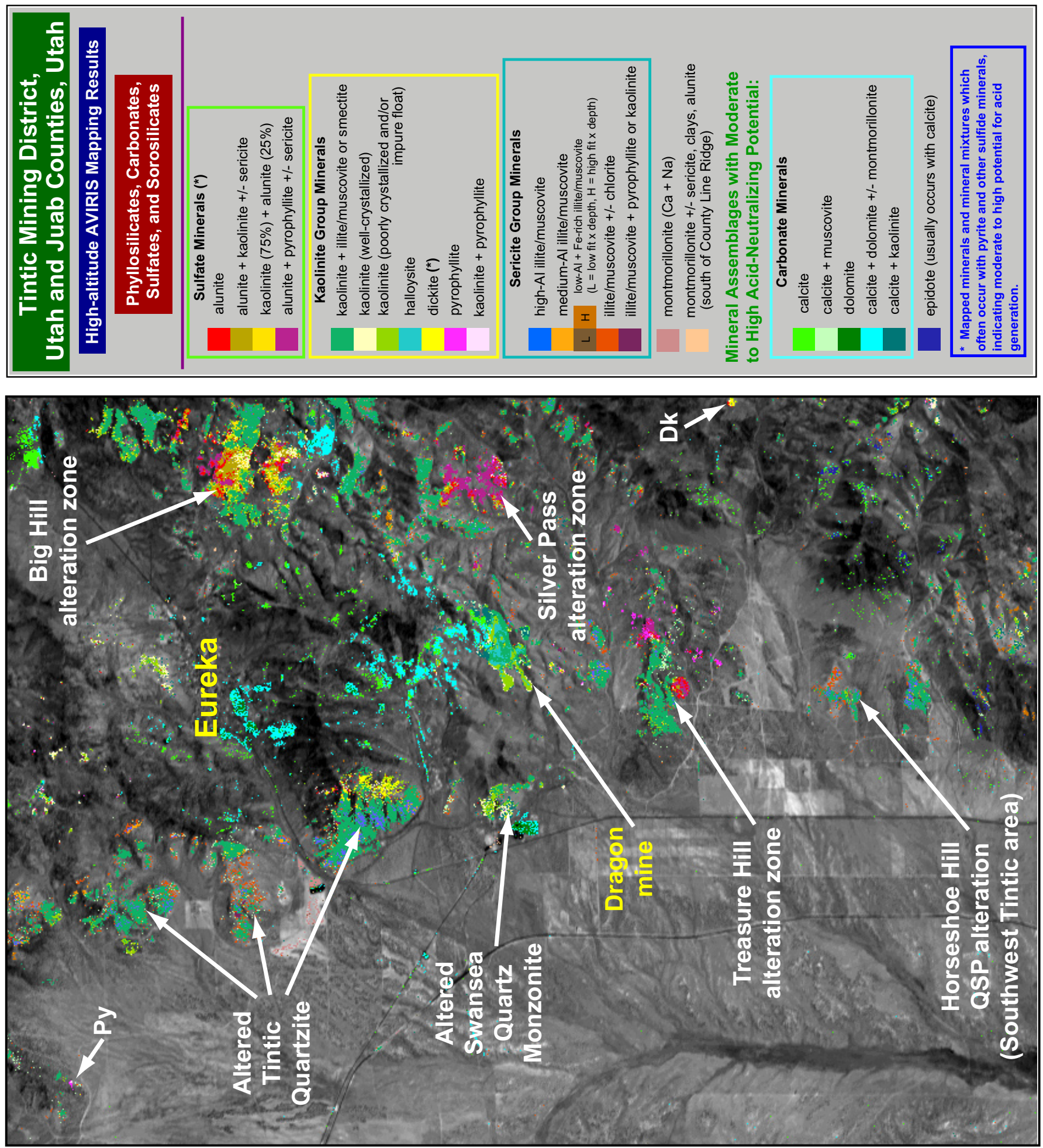


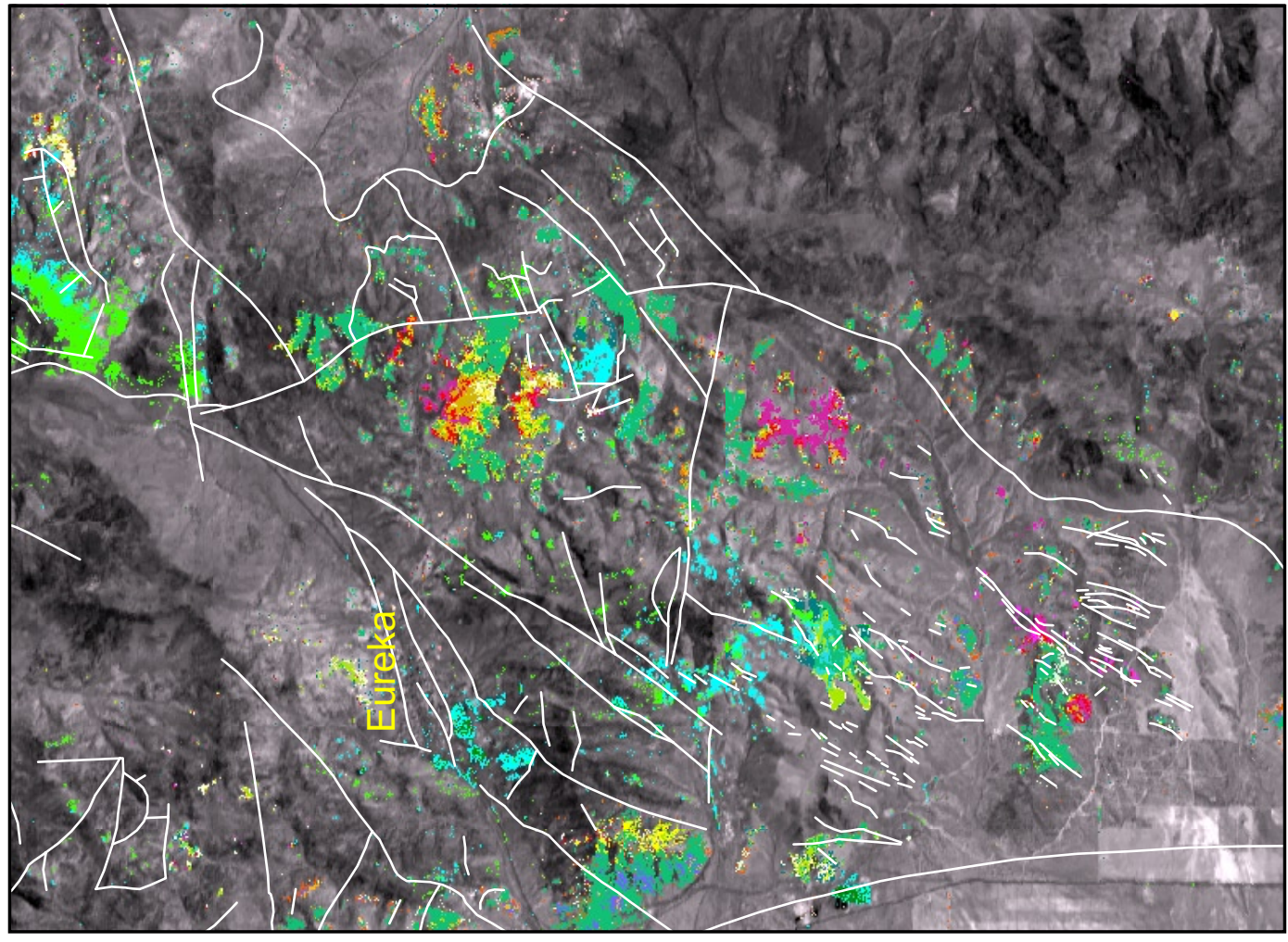

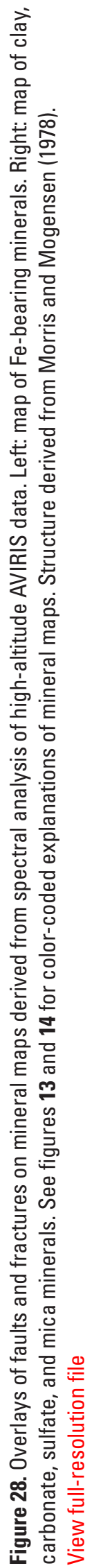

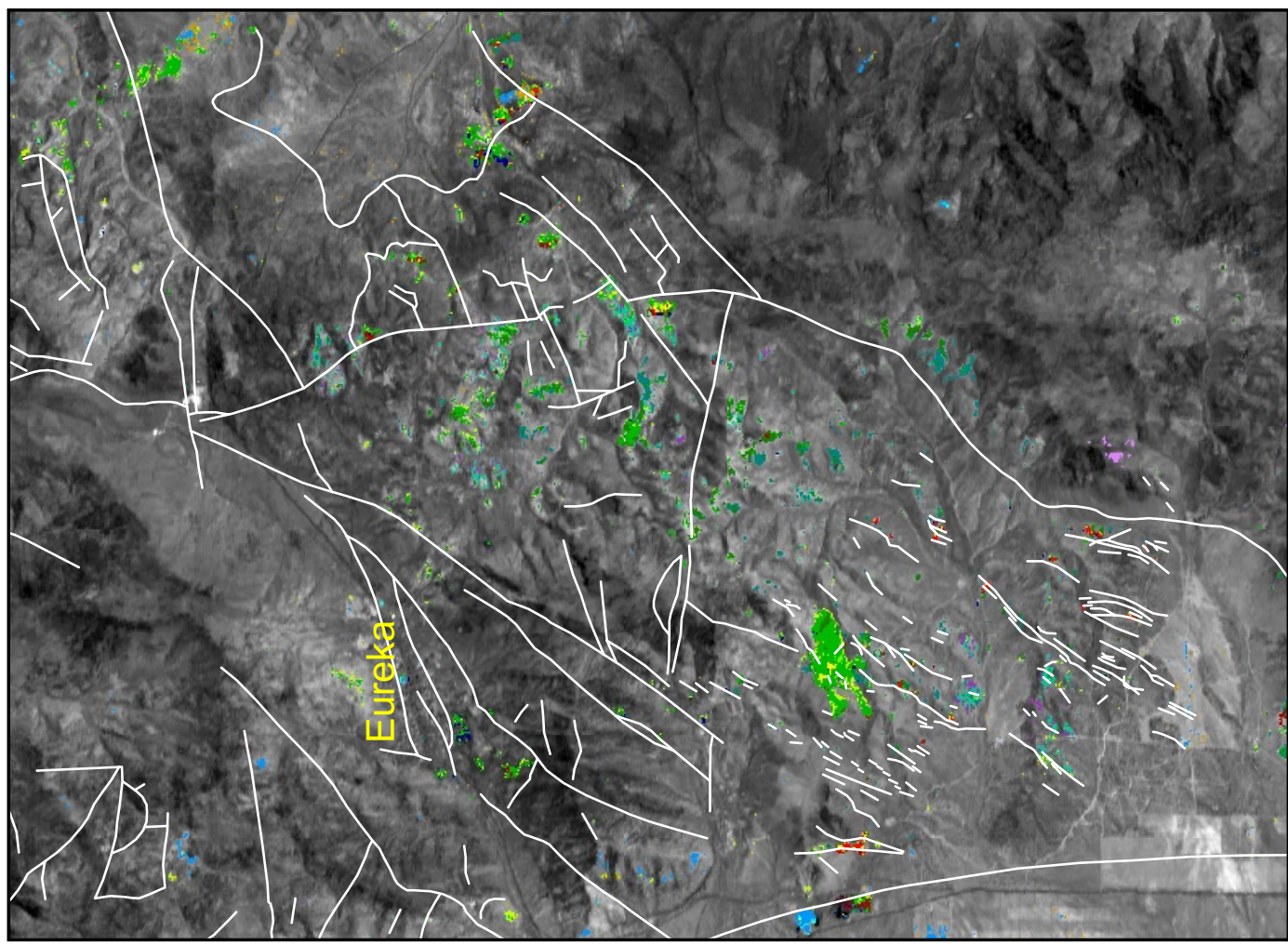


in both spectra. The absorption features used by the Tetracorder expert system for comparing library reference spectra to the AVIRIS spectra are indicated with magenta arrows. The variations in the VIS and NIR regions of the spectra are possibly related to increased amounts of goethite and (or) coarser grain size in the nonanthropogenic jarosite from Silver Pass. This jarosite has been exposed to subaerial weathering processes for an extended period of time; thus, the weathering of these rocks has stabilized, resulting in the production of substantial amounts of goethite as a weathering product. Abundant goethite was detected with the AVIRIS data around all occurrences of jarosite in the district. This spatial relationship is to be expected, as previous studies have indicated that most jarosite will break down to goethite with prolonged exposure to atmospheric water and oxygen (Swayze and others, 2000). However, no goethite was detected by the XRD analyses, suggesting that either the goethite is present in quantities below the detection limit of XRD analysis or the crystal structure of the goethite is amorphous.

Where active sulfide oxidation is still occurring, as is the case on pyrite-bearing waste-rock piles, fine-grained coatings of relatively pure jarosite occur. Although no pyrite was detected in the sample of jarosite and alunite from Silver Pass (appendix table A1, sample TN00-21), pyrite can co-occur with alunite in "magmatic hydrothermal" acid-sulfate systems such as those in the Tintic district (Morris and Mogensen, 1978; Rye and others, 1992). In addition, previous studies have identified pyritized rocks in the Silver Pass area (Lovering, 1960). Therefore, pyrite may exist in the sample, but at levels below the detection limit for XRD. Another possibility is that most pyrite in the sample from Silver Pass has already oxidized to jarosite, goethite, or hematite. The lack of abundant pyrite in the samples of nonanthropogenic jarosite-bearing rocks suggests that, compared to pyrite-rich mine waste, those rocks are likely to have a lower potential for acid generation and related metals mobilization, although the presence of jarosite and alunite in some of these unmined rocks indicates that all rock-buffering capacity has been eliminated through acid leaching and at least some APP exists.

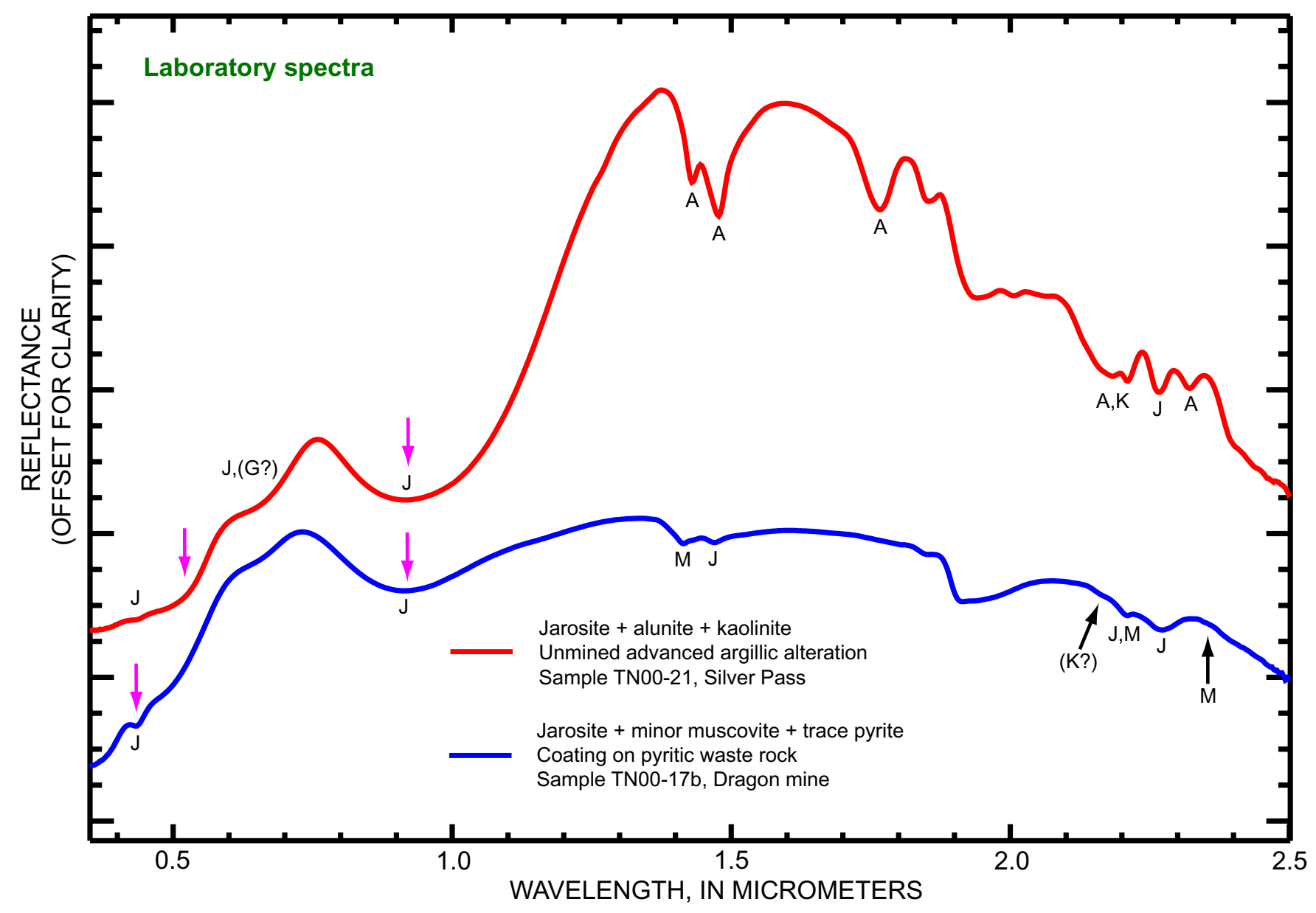

Figure 29. Laboratory spectra of jarosites associated with unmined argillic alteration (red, sample TN00-21) and anthropogenic, pyritebearing mine waste from the Dragon mine (blue, sample TN00-17b). These jarosites were differentiated by the AVIRIS mapping into "coarse-grained" jarosite (Silver Pass alteration zone; location in fig. 27) and "fine-grained" jarosite (mine waste), respectively. Absorption features used by the Tetracorder expert system for identifying each variety of jarosite are indicated with magenta arrows. $\mathrm{A}=$ alunite. $\mathrm{K}=$ kaolinite. $\mathrm{J}=$ jarosite. $\mathrm{M}=$ muscovite. $\mathrm{G}$ = goethite. 


\section{Rocks with Acid-Neutralizing Potential (ANP)}

Carbonate minerals (calcite and dolomite) were detected in association with Paleozoic metasedimentary rocks and propylitic alteration within and adjacent to intrusive rocks. These carbonate-bearing rocks can provide ANP. The AVIRIS mineral map shows that the Paleozoic carbonate-bearing lithologies are best exposed between the Dragon mine and Eureka, north of Homansville Canyon on Pinyon Peak (fig. 2), and $1 \mathrm{~km}$ northwest of the Trixie mine (figs. 14 and $\mathbf{1 8}$ ). Exposures of calcite and epidote associated with propylitically altered igneous rocks were spectrally identified around the Sunrise Peak Monzonite Porphyry at the south end of the district. Exposures of epidote and (or) calcite located 2-3 km south of Horseshoe Hill and in the vicinity of Treasure Hill (fig. 14) are most likely propylitically altered andesitic crystal tuffs associated with the SWT porphyry copper system located from 1 to $3 \mathrm{~km}$ southwest of Horseshoe Hill (Krahulec, 1996). Chlorite-bearing rocks, associated with propylitic alteration caused by the intrusion of the Diamond Gulch stock and Sunrise Peak stock and related sills (Tsps, fig. 9), were spectrally identified in the southern part of the district. Some of these exposures are indicated with a purple "C" in figure 19. Chlorite is significant because it provides some buffering potential for acidic solutions (Desborough and others, 1998).

Calcite, dolomite, and epidote all have diagnostic absorption features near $2.3 \mu \mathrm{m}$. For calcite and dolomite, these features are associated with combinational and overtone vibrational absorptions related to the carbonate radical. For epidote, the feature is possibly associated with $\mathrm{Fe}-\mathrm{OH}$ vibrational absorptions (Clark, 1999). Dry, senescing vegetation also has an absorption feature near $2.32 \mu \mathrm{m}$ caused by structural biochemicals such as lignin and cellulose (Kokaly and Clark, 1999). It is common for ambiguous identifications to occur between carbonate-bearing rocks or soils and dry vegetation during analysis of imaging spectroscopy data of semiarid areas. For this reason, pixels that were spectrally identified as calcite, dolomite, or calcite + dolomite mixtures with low levels of certainty (low values of fit $\times$ depth) were omitted from the mineral maps. A majority of these omitted pixels occurred in the AVIRIS mineral maps in a scattered, "salt-and-pepper" fashion with little or no spatial contiguity. Although many of these pixels represent areal mixtures of carbonate rocks and dry rangeland vegetation, others represent mainly dry vegetation with no appreciable amount of carbonate minerals present. Conversely, it can be assumed that some pixels representing areal mixtures of carbonate-bearing rocks and soil with dry vegetation were spectrally identified as dry vegetation and are thus also not shown on the maps. Other areas underlain by carbonate-bearing rocks or soil are completely masked by vegetation. It is important to interpret the AVIRIS-derived maps of carbonate minerals with these facts in mind, as the actual extent of carbonate-bearing rocks and soils is likely to be significantly greater than what appears on the maps. Geologic maps of the area (figs. 9 and 11) should be consulted to understand the actual extent of carbonate-bearing bedrock.

\section{The Oquirrh Mountains}

\section{Geologic Setting}

The Oquirrh Mountains are located immediately west of Salt Lake City, Utah, and extend $50 \mathrm{~km}$ south from the southern shores of Great Salt Lake (see project index map at http://speclab.cr.usgs.gov/earth.studies/Utah-1/utahproj_large.jpg). The mountains are primarily composed of a sequence of Paleozoic sedimentary rocks that is $>6,700 \mathrm{~m}$ thick. The sedimentary rocks are intruded by igneous rocks throughout the range, and extrusive flows are found on the eastern flank of the range southeast of Bingham Canyon (fig. 30).

In the northern part of the range, the predominant bedrock is the Rogers Canyon sequence, which is 4,900 m thick and composed of the Upper Mississippian Green Ravine Formation (limestone), the Upper Mississippian-Lower Permian Oquirrh Group, and the Lower Permian Park City Formation (limestone and dolomite Grandeur Member). The Oquirrh Group occurs throughout the Oquirrh Mountains and can generally be divided into three units: (1) a lower clastic limestone; (2) a middle unit of alternating beds of limestone, shale, and sandstone; and (3) an upper unit of interbedded quartzite and sandstone. In the north-central part of the range, the stratigraphically incomplete Curry Peak sequence is bounded on the north by the North Oquirrh thrust and on the south by the Midas thrust. The central and southern parts of the range are composed of the Bingham sequence (interbedded sandstone and limestone of the Upper Mississippian Humbug Formation, Great Blue Limestone, Manning Canyon Shale, and the Upper Mississippian-Lower Permian Oquirrh Group) (Tooker and Roberts, 1970; Davis and others, 1994). These rocks have been deformed into a series of northwest-trending folds, including the Ophir anticline near the Mercur mine (Koschmann and Bergendahl, 1968). The folding is the result of Sevier-style "thin-skinned" deformation, with regional principal compression from the southwest (Atkinson, 1976). The complex structure of the Bingham sequence strongly influenced the emplacement of stocks and associated mineral deposits.

\section{Overview of Ore Deposits and Mining History in the Mercur Area, Camp Floyd Mining District, Southern Oquirrh Mountains}

Silver was discovered in Lewiston (now Manning) Canyon (fig. 3) in 1870; the discovery led to the establishment of several underground mines, a mill, and the small town of Lewiston. The Camp Floyd mining district, established in 1870, became the third-largest gold-producing district in Utah. Unlike the other major mining districts in the state, which mine gold as a by-product, the Camp Floyd mining district is known primarily for its gold production. Silver and mercury were mined as secondary metals (Koschmann and Bergendahl, 1968). Fine-grained, disseminated gold was identified in the 


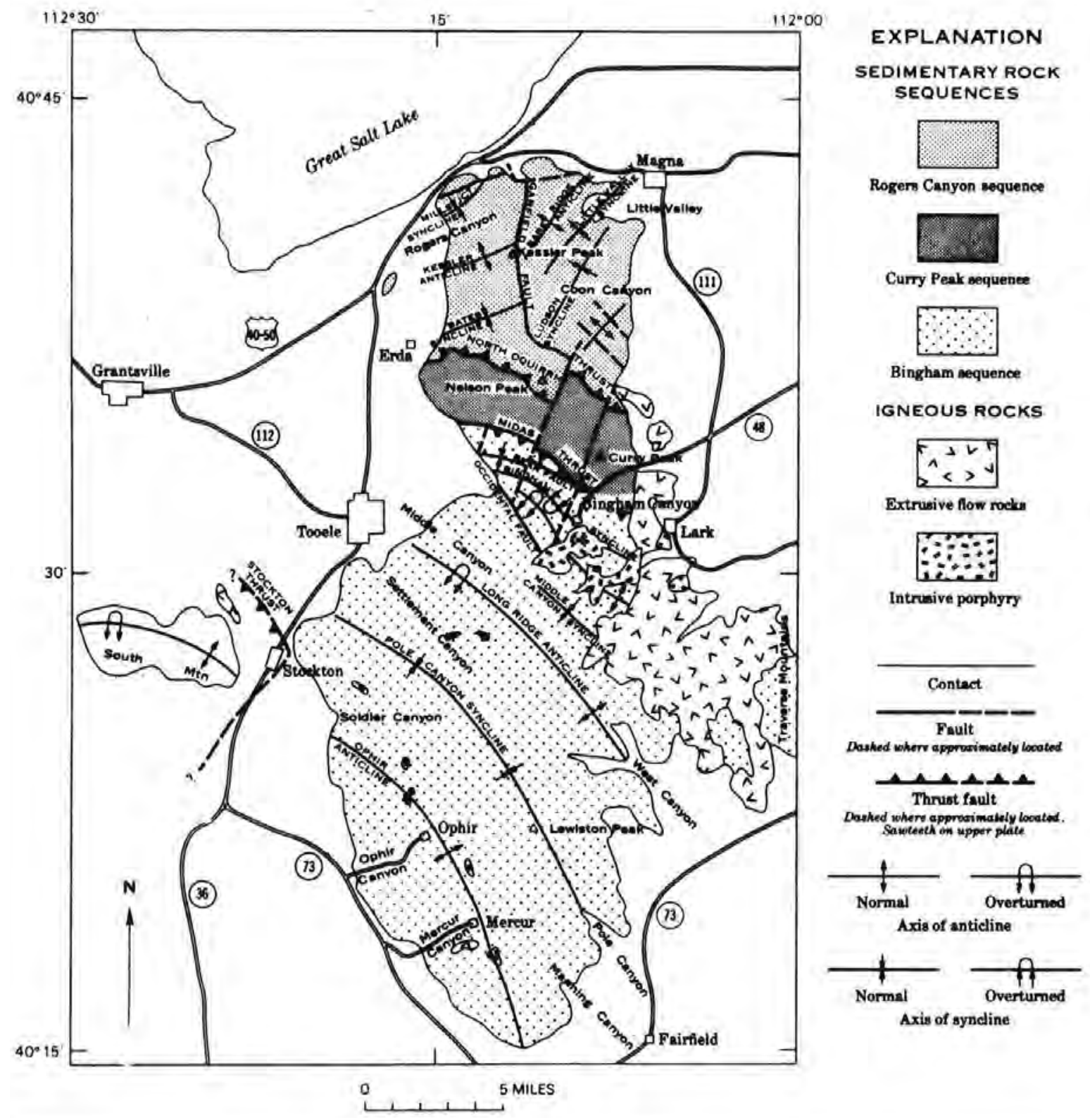

Figure 30. Generalized geologic map of the Oquirrh Mountains (from Tooker and Roberts, 1970).

silver and mercury ores at Lewiston, but no process could be developed to separate the gold. After 1874, production was very limited, and by 1880 the camp was abandoned. In the early 1890 s, the cyanide process for extracting gold from low-grade ores was developed, and a cyanide mill was established in Manning Canyon $\approx 5 \mathrm{~km}$ southeast of the present-day site of the Mercur mine. The ore-processing capacity of this mill improved to 500 tons/day by the late 1890s. In 1897-1898, the Golden Gate mill was built at the head of Mercur Canyon; the capacity initially was 500 tons/day, but eventually grew to 1,000 tons/day (Nash, 2002). The thriving town of Mercur grew around the Golden Gate mill and had a substantial business district. A fire destroyed the town in 1902, and production at the mill ceased in 1913.
Modern, large-scale open-pit mining began at Mercur in 1983 and also involved cyanide leaching for gold extraction. This new mining activity engulfed the old mill and existing tailings (Nash, 2002). Mining ended in 1998 after $>41$ million tons of ore containing 73.8 million g (2.6 million oz) of gold and 32.9 million g (1.2 million oz) of silver were recovered. By-product mercury production totaled 3,469 flasks (Mako, 1999).

Bedded replacement deposits of gold and gold-mercury in the Great Blue Limestone are the major ore deposits in the Mercur area. Fissure veins also contain replacement deposits of gold, gold-mercury, silver, and silver-lead. The gold-bearing replacement deposits contain pyrite, realgar (AsS), orpiment $\left(\mathrm{As}_{2} \mathrm{~S}_{3}\right)$, and cinnabar $(\mathrm{HgS})$ (Koschmann and Bergendahl, 
1968). The area contains one of the principal deposits of realgar and orpiment in the United States (Hurlbut and Klein, 1977).

Deposits of the Mercur Canyon outwash are located near the eastern edge of Rush Valley, $\approx 32.2 \mathrm{~km}$ south of the town of Tooele (fig. 3). These tailings, originating from the Mercur mine area, have been distributed both within Mercur Canyon and over a wide area down-gradient from the mouth of the canyon in Rush Valley. The failure of historical tailings dams may have resulted in the deposition of the fine-grained tailings (Nash, 2002). Underneath these tailings, older transported material in the outwash deposits contains anthropogenic debris and mine-waste rock, suggesting that the earliest release(s) from the Mercur area involved flooding in the town and near the mines and mill. Elevated levels of arsenic and mercury $(3,500 \mathrm{mg} / \mathrm{kg}$ and $19 \mathrm{mg} / \mathrm{kg}$, respectively) have been reported to exist in the tailings (ICF Technology Incorporated, 1989). Tailings from historical milling operations in Manning Canyon were also found to contain high levels of arsenic and other metals.

\section{Overview of Ore Deposits and Mining History in the Stockton Mining District}

The Stockton (or Rush Valley) mining district is located on the western flank of the Oquirrh Mountains between the Ophir and Camp Floyd mining districts to the southeast and the Bingham mining district to the northeast (fig. 3). Mining began in the Stockton mining district in 1864 after silver deposits were found to the west in Rush Valley (Gilluly, 1932). The district is known primarily for lead, silver, copper, and zinc; gold was recovered as a by-product of the base metal ores (Koschmann and Bergendahl, 1968). The Honorine mine, located just east of the town of Stockton, was the site of the most significant ore deposits in the district. In the Stockton mining district, the massive sulfide ores occur in bedded replacement deposits in the Oquirrh Group where limestone beds intersect faults and fissures. In the Ophir area (fig. 3), the ores occur in replacement deposits in the Mississippian Great Blue Limestone. The primary ore minerals in both areas were galena, sphalerite, chalcopyrite, arsenopyrite, and argentite; quartz, pyrite, and calcite constituted the gangue minerals (Gilluly, 1932).

The Bauer Mill, located $\approx 2.5 \mathrm{~km}$ north of Stockton, processed ores from the Stockton mining district and other mines in the western United States from 1900 until 1957 by using selective flotation (Gilluly, 1932; John and Ballantyne, 1997). Deposits of tailings rich in sulfide minerals (mainly pyrite) accumulated at the mill site during this period.

The International Smelter and Refining mill, located 3 $\mathrm{km}$ east of Tooele (fig. 3), processed sulfide ores of copper, lead, and zinc from 1910 to 1972 . The site was reclaimed in 1986. Federal, State, and local government agencies are currently interested in evaluating the effectiveness of the original reclamation efforts. The International Smelter and Refining site was included on the U.S. Environmental Protection Agency's National Priority List on July 27, 2000 (Steven Thiriot, Utah Department of Environmental Quality, written commun., 2001; U.S. Environmental Protection Agency, 2002b).

\section{Mapping and Characterization of Mine Waste in the Oquirrh Mountains Region}

Maps of surface minerals and water were generated from the high-altitude AVIRIS data covering the Oquirrh Mountains (figs. 31-36). Minerals were identified in only a small percentage of processed AVIRIS pixels because most of the region within and surrounding the Oquirrh Mountains is covered with dry vegetation including piñon, juniper, sage, grasses, and more dense riparian communities along watercourses. Such vegetation obscures the mineral signatures in the underlying soil and bedrock. Regionally, the mineral mapping based on the high-altitude AVIRIS data revealed a broad distribution of carbonate minerals (mainly calcite and dolomite) throughout the Oquirrh range, presumably associated with the Paleozoic sedimentary rocks (fig. 30). These carbonate rocks provide substantial ANP.

Figure 31 (page 44, left). Map of iron-bearing minerals and water in the western Oquirrh Mountains, Utah, generated from run 7 of the high-altitude AVIRIS data. The Stockton mining district, Bauer Mill tailings, and Mercur Canyon outwash deposits are shown. The map has not been field verified within the Deseret Chemical Depot.

View full-resolution file

Figure 32 (page 44, right). Map of clay, carbonate, sulfate, and mica minerals in the western Oquirrh Mountains, Utah, generated from run 7 of the high-altitude AVIRIS data. The Stockton mining district, Bauer Mill tailings, and Mercur Canyon outwash deposits are shown. The map has not been field verified within the Deseret Chemical Depot.

View full-resolution file

Figure 33 (page 45, left). Map of iron-bearing minerals and water in the central Oquirrh Mountains, Utah, generated from run 9 of the high-altitude AVIRIS data. The International Smelter and Refining site east of Tooele, the Mercur mine, and part of the Mercur Canyon outwash deposits are shown. The map has not been field verified on the Mercur mine site.

View full-resolution file

Figure 34 (page 45, right). Map of clay, carbonate, sulfate, and mica minerals in the central Oquirrh Mountains, Utah, generated from run 9 of the high-altitude AVIRIS data. The International Smelter and Refining site east of Tooele, the Mercur mine, and part of the Mercur Canyon outwash deposits are shown. The map has not been field verified on the Mercur mine site. View full-resolution file 

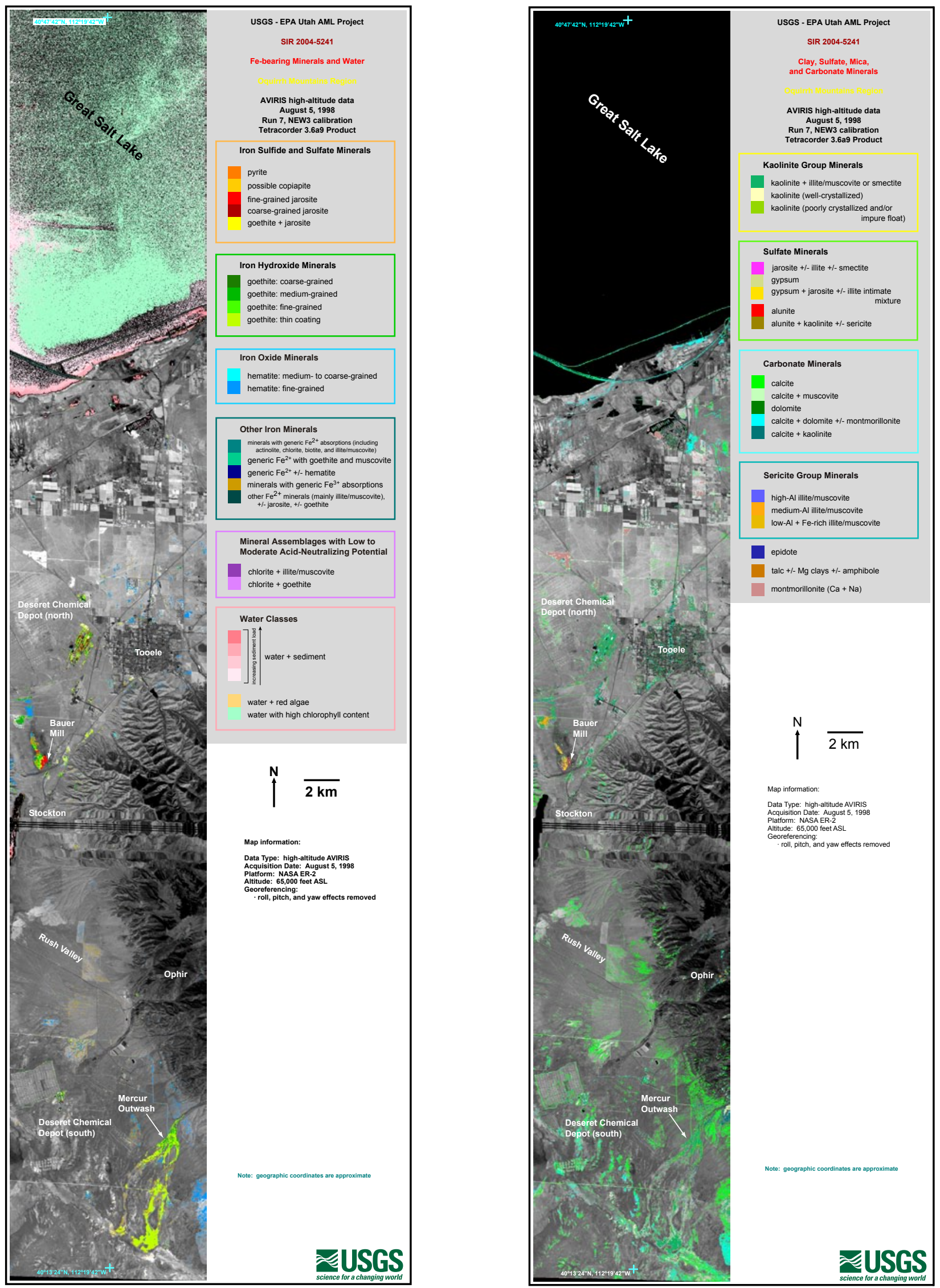

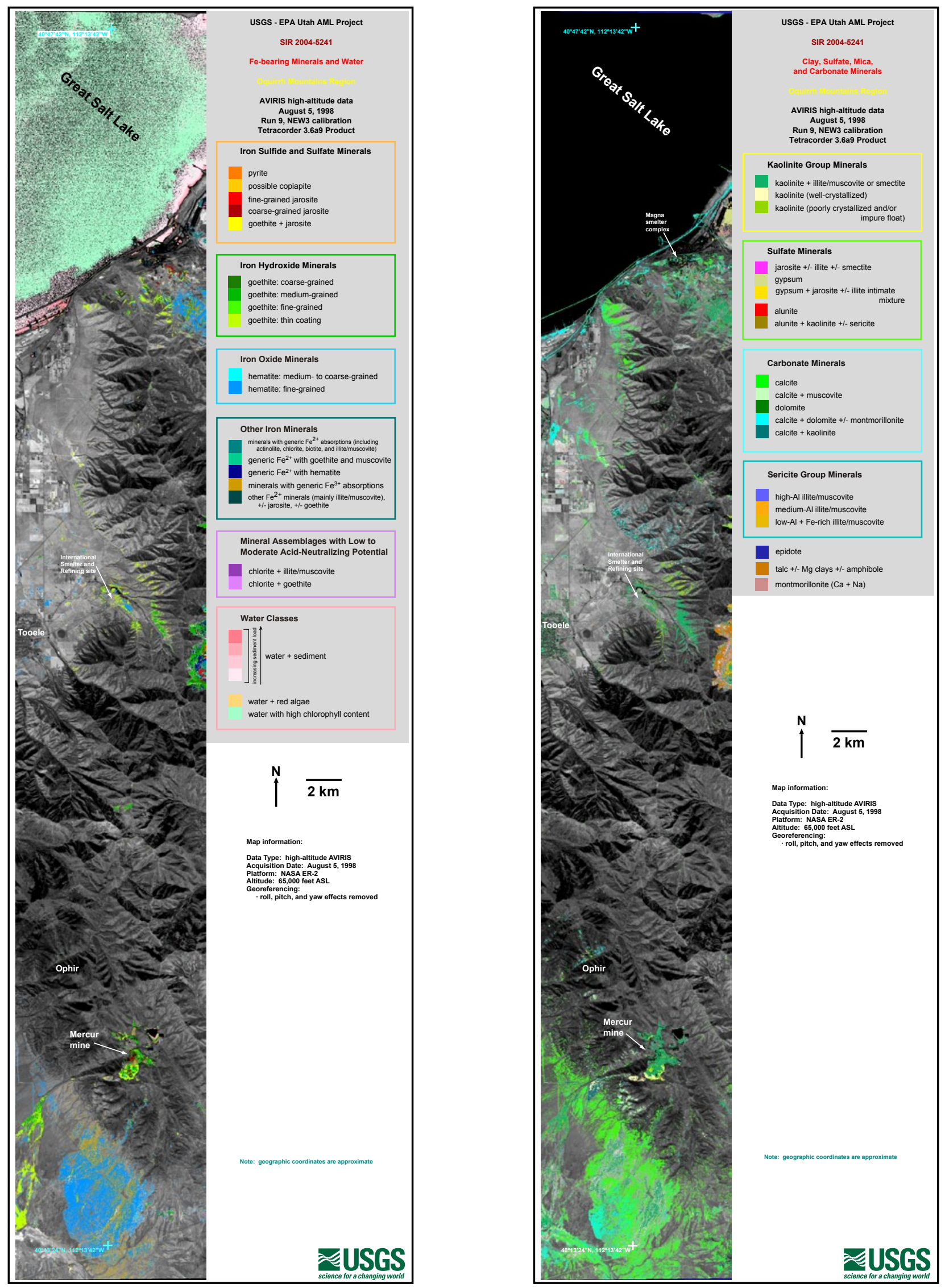


\section{Mercur Canyon Outwash and Manning Canyon}

Preliminary AVIRIS-derived mineral maps of the Mercur Canyon outwash and Manning Canyon (McDougal and others, 1999) were used to examine the mineral assemblages in, and areal distribution of, mine tailings and to guide subsequent field verification and sampling efforts. These preliminary maps clearly indicated the extent of tailings derived from the Mercur mine area in the southern Oquirrh Mountains.

\section{Mineral-Distribution Patterns}

The deposits of the Mercur Canyon outwash are seen clearly in a continuous-tone map of iron oxide and Al-OH (including clays, sulfates, and micas) or carbonate mineral groups derived from Landsat 7 ETM+ data (fig. 37) and in the AVIRIS-derived mineral maps (figs. 31-34). The AVIRISderived mineral maps show that goethite, kaolinite, and kaolinite + muscovite mixtures spectrally dominate the deposits. Figure 38 shows that the alluvial deposits are fine grained and weakly bedded; they overlie coarser-grained sediments that appear to be nonanthropogenic, alluvial-fan deposits, although some of this coarser material may be derived from flooding in and around the town of Mercur and the local mines and mill (Nash, 2002). The deposits extend $\approx 9.7 \mathrm{~km}$ southwestward from the mouth of Mercur Canyon, through the Deseret Chemical Depot (south), to the central closed basin of Rush Valley (fig. 3). Pixels identified as coarser-grained goethite within the tailings deposits may indicate areas where the deposits are thicker-and associated trace metals therefore more abundant—whereas thin coatings of goethite most likely indicate areas where tailings material is present only as a thin surface veneer, as is the case in the most distal parts of the Mercur Canyon outwash deposits in Rush Valley (figs. 31 and 33). Within Mercur Canyon downstream (southwest) from the Mercur mine, small deposits of similar tailings exist along the stream channel, which is dry for most of the year. These remnant fluvial deposits are too small to be resolved with the high-altitude AVIRIS data. Sediment with a similar mineral assemblage was spectrally identified on the southeast side of the range in Manning Canyon and in cultivated fields down-gradient to the southeast near the town of Fairfield (figs. 35 and 36). The deposits in Manning Canyon are concentrated in a large pile at the mill site (fig. 39), although thick deposits similar to those of the Mercur Canyon outwash extend away from the mill site toward the southeast (fig. 40). Tailings at two locations near the mining site of Sunshine in Sunshine Canyon several kilometers west and southwest of Clay Canyon (figs. 3, 33, and 34) yielded similar spectra. Kaolinite and minor amounts of alunite were spectrally identified in small open-pit mines in Clay Canyon $2.5 \mathrm{~km}$ southwest of the Manning Canyon mill site. These minerals were verified by field survey (fig. 41). Small exposures of alunitic rocks were identified within much larger envelopes of highly kaolinized rocks.

AVIRIS-derived maps show iron minerals, illite/muscovite, and mixtures of kaolinite and illite/muscovite being transported out of the Oquirrh Mountains. Mixtures of kaolinite and illite/muscovite were spectrally identified directly down-gradient (southwest) from large canyons in the Oquirrh Mountains, including Sunshine, Mitchell, and McFait Canyons, and within the mountains along Mitchell Canyon (fig. 3). The mixtures were easily detected on alluvial-fan surfaces in several areas exposed by a range fire several kilometers southeast of the Mercur Canyon outwash (figs. 33, 34, and 37). These fan surfaces are surrounded on all sides by calcite-bearing alluvium derived from sedimentary rocks in the range. Unlike the tailings in the Mercur Canyon outwash and Manning Canyon that contain abundant goethite and (or) amorphous iron hydroxides, these fan surfaces are characterized mainly by coatings of fine-grained hematite. Such coatings have been observed on soil and rock surfaces in other areas affected by range and forest fires (figs. 15 and 26, Kokaly and others, 2002) and may be formed in part by the high-temperature oxidation of iron minerals by the fire. Unlike the tailings of the Mercur Canyon outwash, no pixels of spectrally pure kaolinite were recorded on these fan deposits. Sericite and minor kaolinite were observed with a field spectrometer in the altered groundmass of a cobble of weakly altered quartzite from this area. The geomorphologic and mineralogic evidence suggests that these fan deposits are nonanthropogenic alluvium derived from argillically altered rocks that have been for the most part removed from the southern Oquirrh Mountains by erosion. Highly kaolinized rocks still remain southwest of the Mercur mine, near the mouth of Mercur Canyon in bleached outcrops along fracture zones, and on down-gradient pediment surfaces immediately to the southwest.

Figure 35 (following page, left). Map of iron-bearing minerals and water in the eastern Oquirrh Mountains, Utah, generated from run 6 of the high-altitude AVIRIS data. The Manning Canyon tailings, Bingham Canyon mine, and Magna smelter complex are shown. This map has not been field verified in the vicinities of the Bingham Canyon mine or Magna smelter.

View full-resolution file

Figure 36 (following page, right). Map of clay, carbonate, sulfate, and mica minerals in the eastern Oquirrh Mountains, Utah, generated from run 6 of the high-altitude AVIRIS data. The Manning Canyon tailings, Bingham Canyon mine, and Magna smelter complex are shown. On this map, six spectrally identified mineral assemblages are displayed through the use of continuous stretches (marked " $C$ " in color key; see Spectral Analysis chapter) in which the brightness level of the color selected for that assemblage decreases with decreasing spectral fit $\times$ depth of the material identification. Note that the fit $x$ depth (and spectral abundance by extension) of the kaolinite + illite/muscovite assemblage is significantly higher in the Bingham Canyon mine area than in (1) the tailings in Manning Canyon and (2) on the flanks of the Oquirrh Mountains south of the Magna smelter complex that have been denuded of vegetation (and possibly altered) by sulfurbearing smelter emissions. This map has not been field verified in the vicinities of the Bingham Canyon mine or Magna smelter. View full-resolution file 

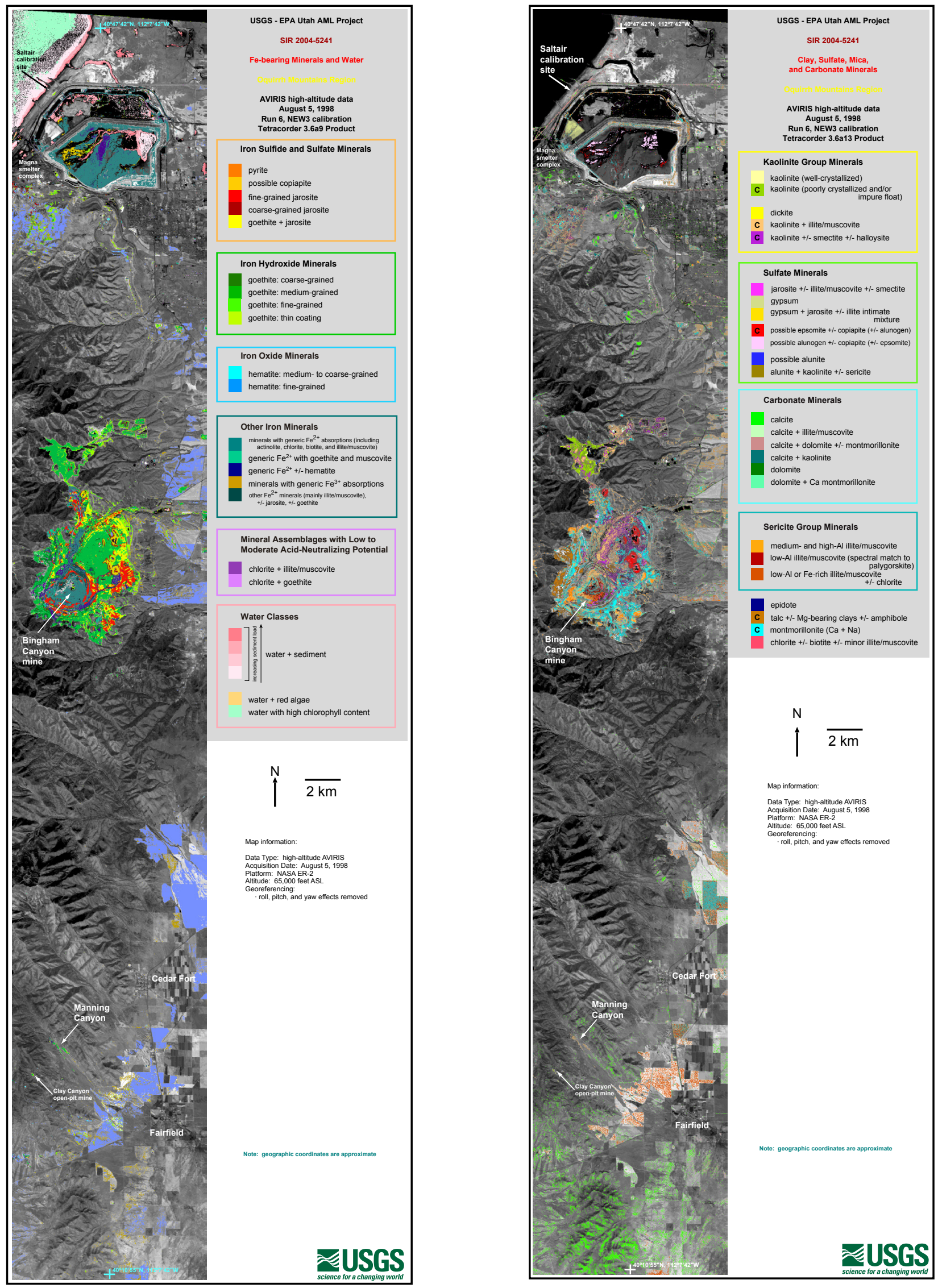


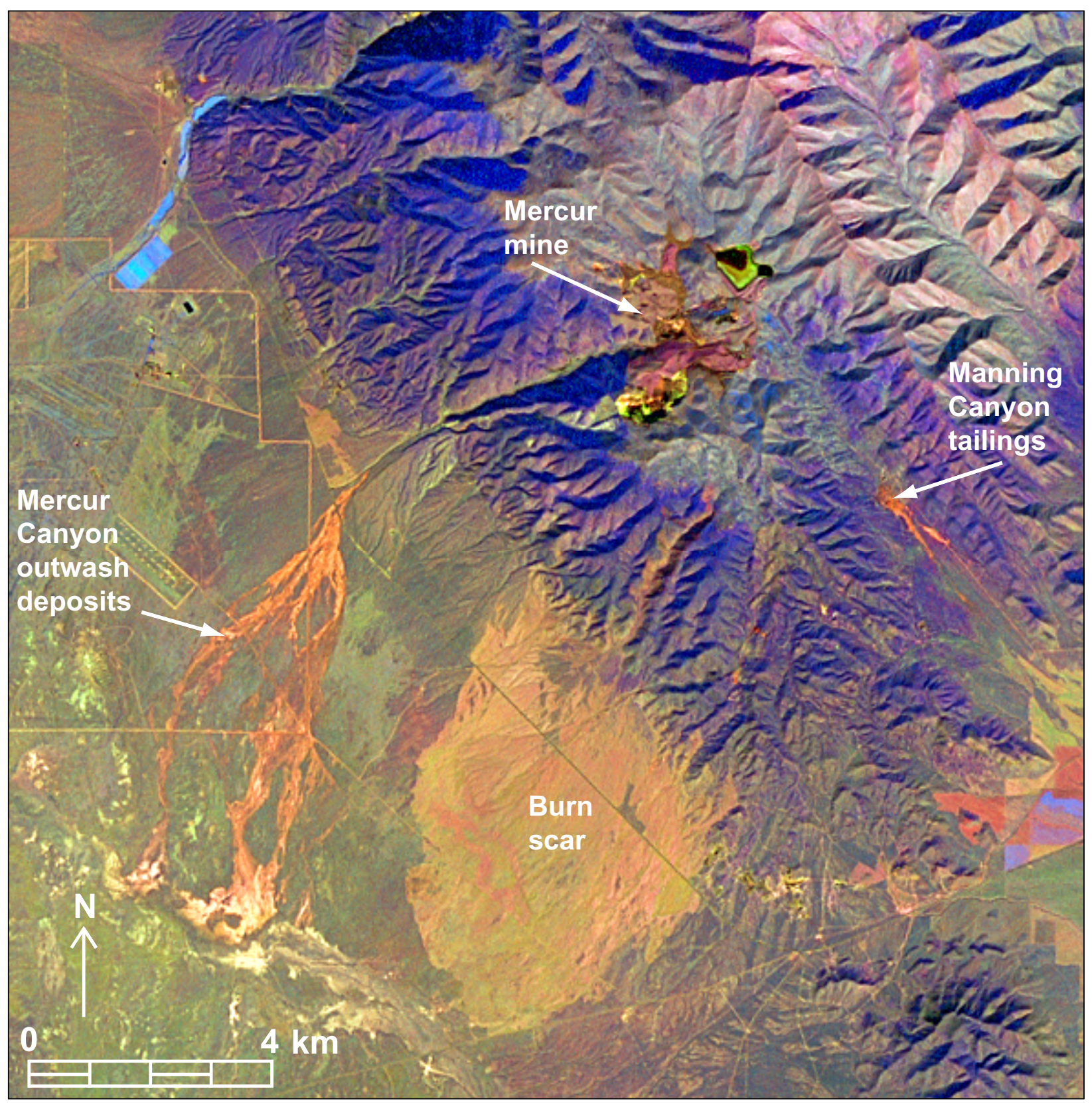

Figure 37. Landsat 7 ETM+ continuous-tone map of mineral groups and vegetation centered on the southern Oquirrh Mountains, Utah. The Mercur gold mine is near top center. The Mercur Canyon outwash deposits are visible in Rush Valley at left, and tailings in Manning Canyon are southeast of the Mercur mine. Image center point: $40^{\circ} 17^{\prime} 30^{\prime \prime} \mathrm{N} ., 112^{\circ} 13^{\prime} 49^{\prime \prime} \mathrm{W}$. Interpretation guide:

Red: rocks and soils bearing hematite and (or) other ferric iron minerals. : $\mathrm{Fe}^{3+}+$ clays, sulfates, and micas (mostly hydrothermal alteration).

Green: clays, sulfates, and micas, \pm carbonates, with possible bleaching.

Cyan: green, moist vegetation.

Blue: green, dry vegetation.

View full-resolution file 


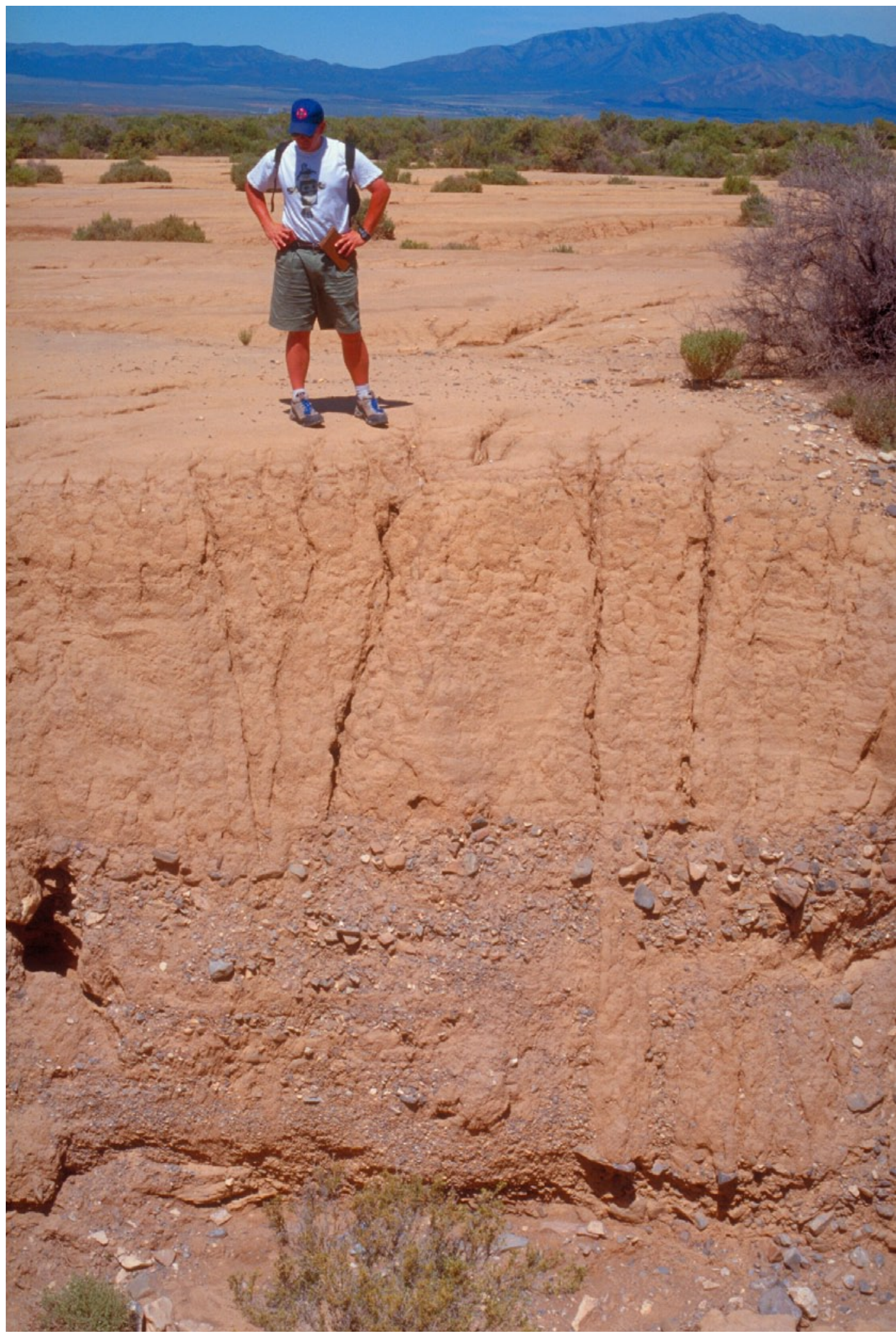

Figure 38. Tailings in the Mercur Canyon outwash, Rush Valley. This photograph was taken in a gully $\approx 100 \mathrm{~m}$ south of Route 73 , which runs through the deposits. Vegetation on the tailings is largely limited to saltbush. The weakly bedded nature of the deposits is evident. The youngest (upper) sediments contain anomalously high concentrations of metals and overlie much coarser-grained alluvial sediments, which may be nonanthropogenic alluvial-fan deposits. 

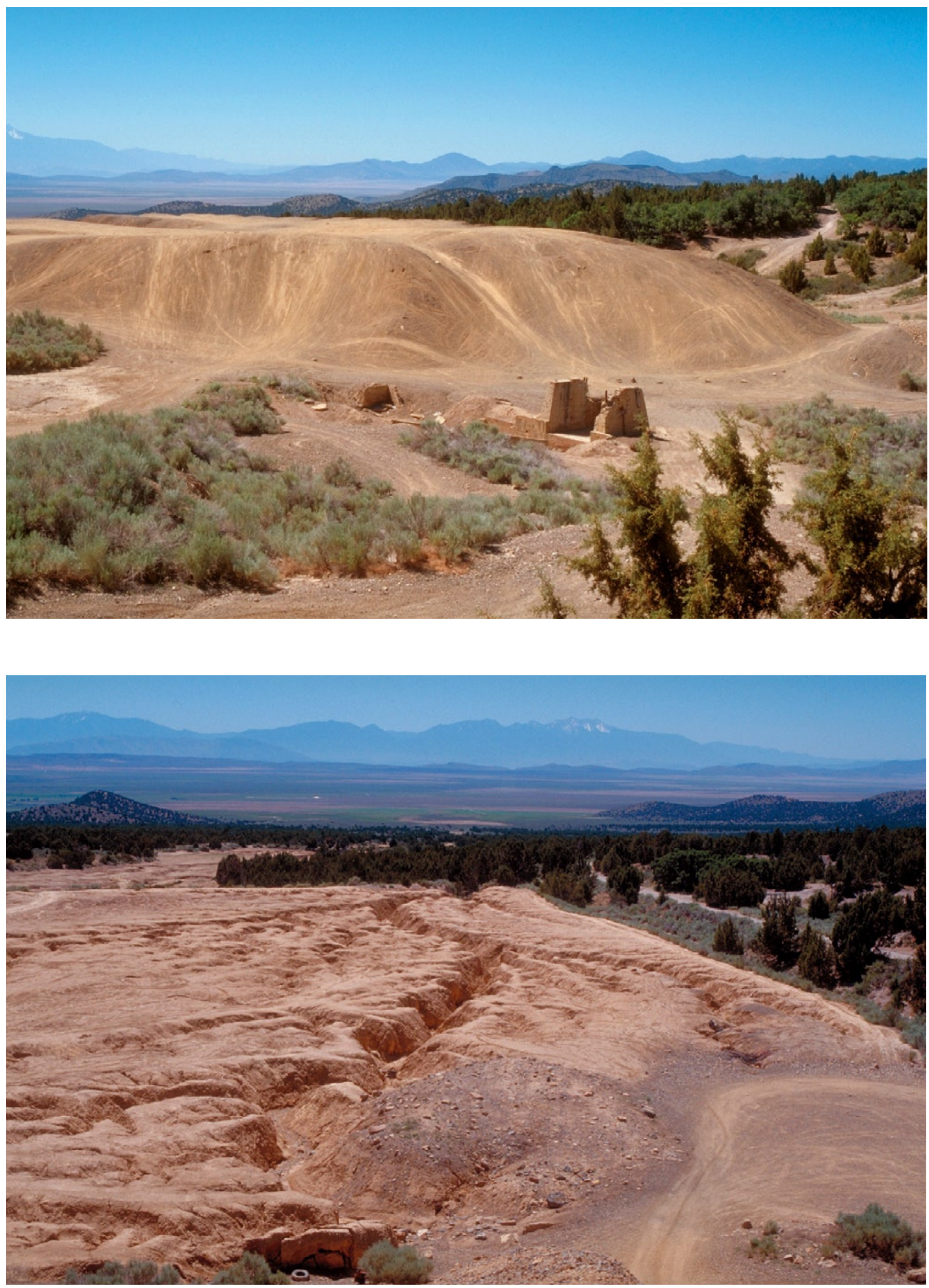


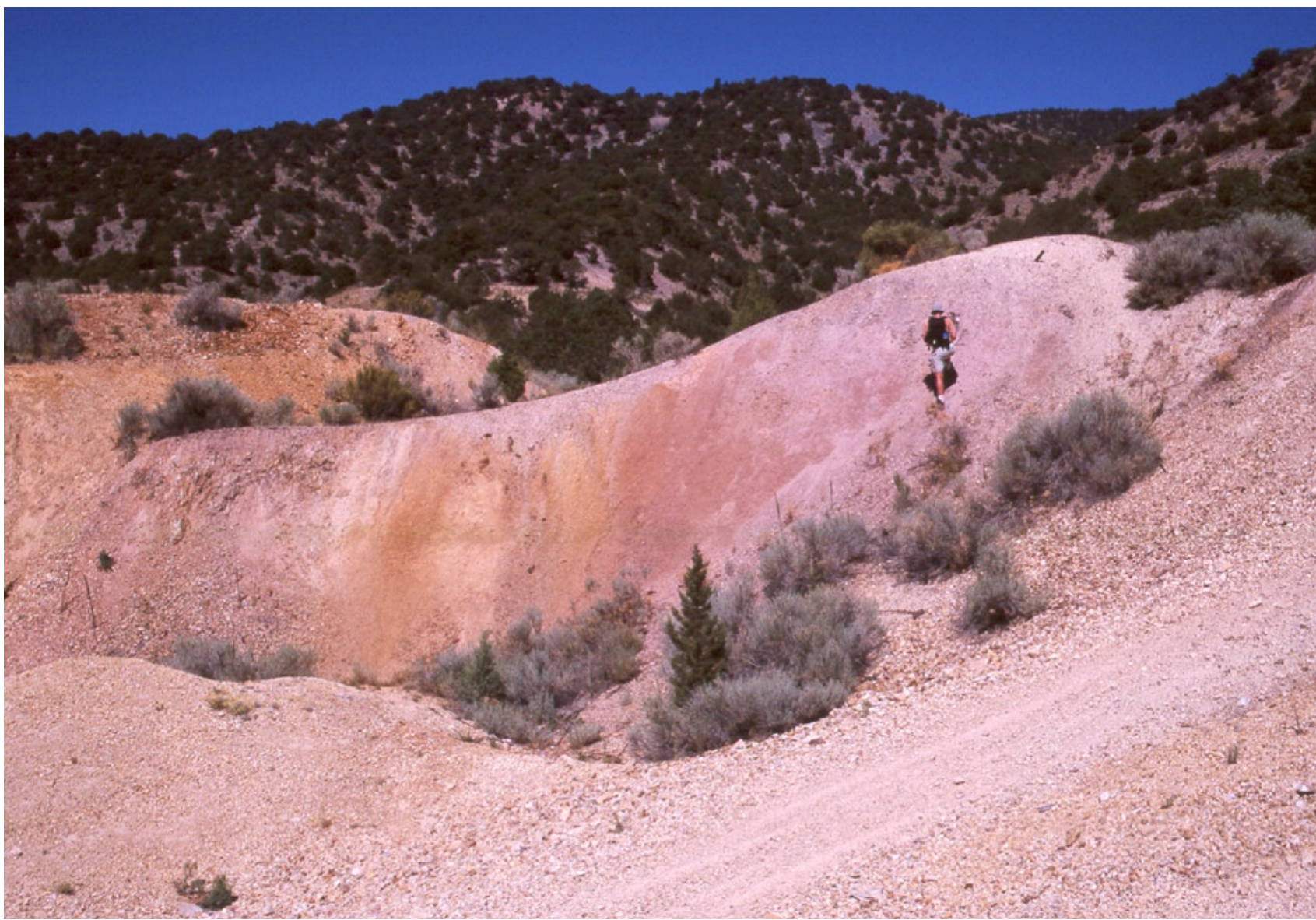

Figure 41 (this page, top). Open-pit clay mine in Clay Canyon, southern Oquirrh Mountains. Large envelopes of highly argillized rock containing goethite and kaolinite (pictured here) surround small zones of alunite. Location: $40^{\circ} 16^{\prime} 52.85^{\prime \prime} \mathrm{N}$., $112^{\circ} 10^{\prime} 43.24^{\prime \prime} \mathrm{W}$.

Figure 39 (preceding page, top). Tailings at the remains of the ore-processing mill in Manning Canyon, southeastern Oquirrh Mountains. Note tracks of motorcycles and all-terrain vehicles on the tailings pile. The view here is toward the south; Cedar Valley and the East Tintic Mountains are in the background. Part of Mount Nebo (with snow) is just visible at the extreme left.

Figure 40 (preceding page, bottom). Tailings extending down-gradient toward the southeast from the mill site in Manning Canyon, southeastern Oquirrh Mountains. Mount Nebo (with snow) is visible in the background. Soils bearing kaolinite, illite/muscovite, and goethite similar to the tailings material were spectrally identified as far as $5 \mathrm{~km}$ down-gradient from the mill site in the vicinity of the cultivated fields visible in the middle distance. 


\section{Field and Laboratory Analyses}

Field verification for the Oquirrh Mountain study focused on the tailings of the Mercur Canyon outwash and Manning Canyon in the southern part of the Oquirrh range (fig. 3). Field work included collection of field X-ray fluorescence (XRF) data, field spectroscopic data, and samples of soil and rock. Field XRF measurements were used to determine the presence and approximate concentrations of metals in soils, but are not as accurate as laboratory XRF measurements. Field spectroscopic data were collected to confirm the accuracy of mineral identifications made by the spectral analysis of the AVIRIS data and to allow future studies of possible changes in spectral features associated with elevated levels of metals. Soil and rock samples were also collected for subsequent laboratory characterizations using spectroscopy and XRD.

Eleven soil samples taken from the Mercur Canyon outwash were examined by using XRD (appendix table A2). All of the samples consisted primarily of quartz, calcite, and kaolinite; muscovite was found in minor to trace amounts in all of the samples. Clay minerals in the samples were determined to be primarily kaolinite rather than halloysite, and minor to trace amounts of montmorillonite also were present. Halloysite was not found in any of the samples, although it can be difficult to differentiate halloysite from kaolinite with XRD when the minerals occur in minor to trace amounts. The revised Tetracorder mapping presented in this report correctly identifies most of the Mercur Canyon outwash deposits as either kaolinite or kaolinite + muscovite mixtures (figs. 32 and 34).

Although the tailings deposits in the Mercur Canyon outwash and Manning Canyon are characterized by strong electronic absorptions in the VIS and NIR spectral regions that are similar to those of goethite, XRD analyses of the tailings and local background soil detected no iron-bearing minerals other than trace amounts of pyrite in several samples (appendix table A2). The field XRF data indicated high iron concentrations in the tailings as well as in the background soils. In the Mercur Canyon outwash, iron values ranged from $14,000-17,000$ ppm in the background soils to 6,000-34,000 ppm in the tailings. Similarly, in the samples from Manning Canyon, iron values ranged from 13,000-15,000 ppm in the background soils to $11,000-29,000 \mathrm{ppm}$ in the tailings. As $\mathrm{XRD}$ is not effective in detecting minerals that have a poorly formed, or "amorphous," crystalline structure, it is assumed that the iron hydroxides in the background soils and tailings are most likely poorly crystalline or amorphous.

Elevated levels of arsenic, chromium, strontium, and lead were identified by the XRF field measurements of the tailings at both locations (appendix table A2). Zinc was also present in most of the samples at lower concentrations ranging from 90 to $250 \mathrm{ppm}$. In general, zinc values were higher in tailings from Manning Canyon than in tailings from the Mercur Canyon outwash, possibly because the tailings in Manning Canyon were more concentrated owing to their proximity to the mill. In the Mercur Canyon outwash, arsenic values ranged from 71-103 ppm in the background soils to $1,200-11,000 \mathrm{ppm}$ in the proximal and distal parts of the tailings. At Manning Canyon, arsenic values ranged from $82-253 \mathrm{ppm}$ in the background soils to $1,160-9,600 \mathrm{ppm}$ in the tailings.

\section{Discussion}

Although imaging spectroscopy cannot directly detect elemental concentrations, the distribution of metals can be inferred by the extent of iron hydroxides mapped with the AVIRIS data. Previous studies of mine tailings similar to those examined here indicate that elemental arsenic will preferentially adsorb to poorly crystalline (amorphous) iron hydroxides in near-neutral pH environments (Bowell, 1994). At the Mercur Canyon outwash (fig. 31) and Manning Canyon (fig. 35), field studies verified that the highest levels of arsenic correlated well with the spectrally identified goethite deposits. The high-altitude AVIRIS maps of Manning Canyon (figs. 35, 36, and 40) show occurrences of mineral assemblages similar to those of the tailings along drainages and in cultivated fields down-gradient (southeast) from the mine tailings. The maps may be useful in directing future scientists' collection of ground samples that can be tested for elevated metal levels.

\section{Bauer Mill Site and Tailings near Ophir Canyon}

Of the sites investigated in detail as a part of this study of the Oquirrh Mountains, the pyrite-rich tailings at the site of the Bauer Mill near Stockton have the greatest potential for acid generation and subsequent leaching of heavy metals from the waste material (fig. 42). The tailings are in a closed hydrologic basin; thus, any impact of metal contamination on surface water is probably limited; however, the extent of ground-water contamination, if any, is not known. The greatest potential for environmental impact from the tailings is likely their mobilization by the prevailing southerly winds (Steven Thiriot, Utah Department of Environmental Quality, oral commun., 2001).

Pyrite was spectrally identified in several pixels located in the southeastern part of the tailings near the site of the mill (fig. 43). Generally, pyrite is difficult to detect through the use of high-altitude AVIRIS data because of pyrite's low reflectance (albedo) and weak absorption features. A pyrite-rich core area immediately adjacent to the mill site grades spectrally toward the west and northwest into fine-grained jarosite, jarosite + goethite areal mixtures, goethite, generic ferric iron, and locally to hematite. This type of zonation pattern, attributed to the oxidation of pyrite, was also identified in waste rock at mines near Leadville, Colorado (Swayze and others, 2000). Another occurrence of jarosite and jarosite + goethite was spectrally identified $\approx 1 \mathrm{~km}$ northwest of the mill site. This secondary area of tailings may be related to an impoundment breach near the mill site and subsequent release of tailings toward the north. The distribution pattern of iron-bearing minerals in 


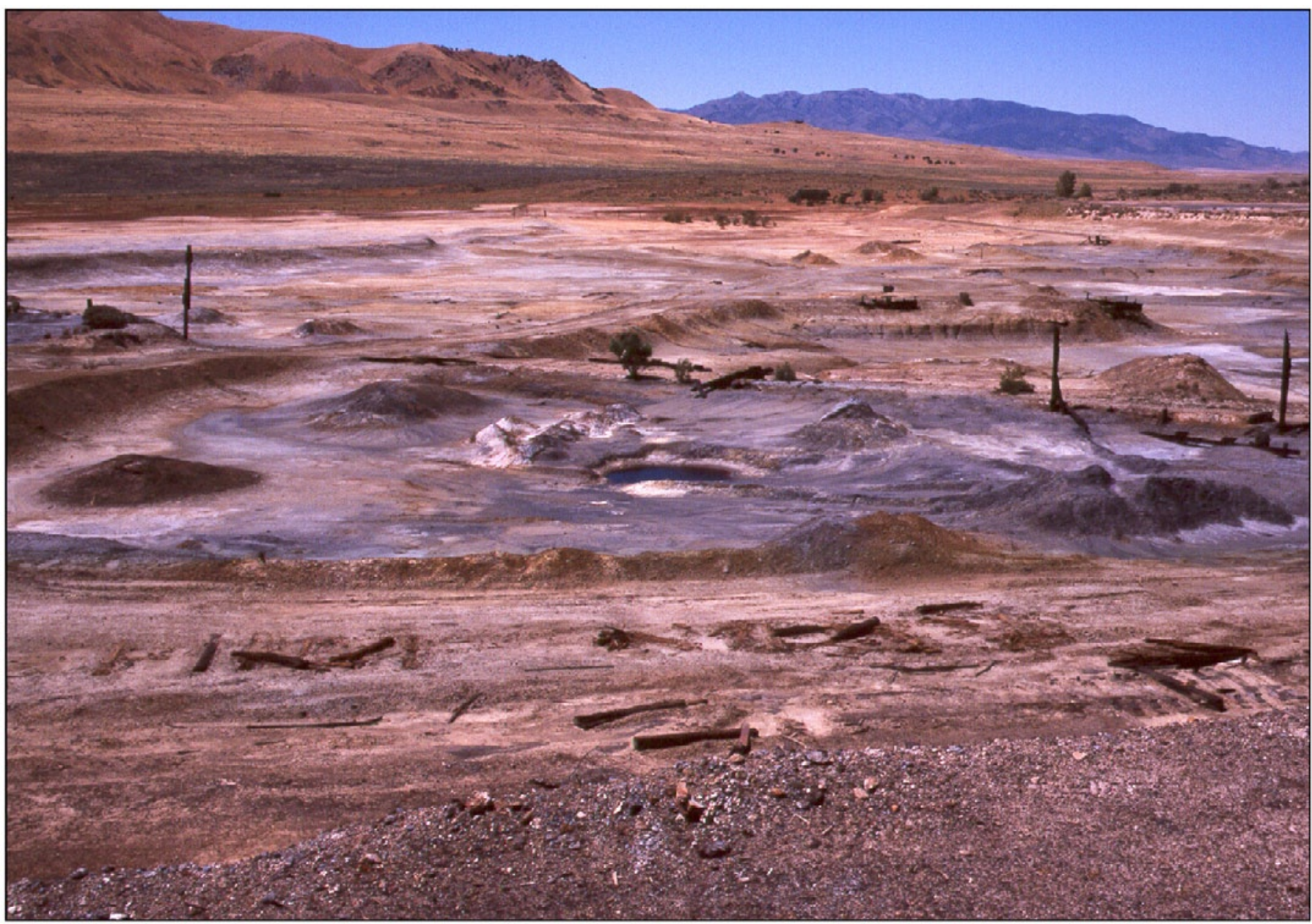

Figure 42. Pyrite-bearing tailings and other waste at the site of the Bauer Mill near Stockton, Utah. View is toward the northwest from near the ruins of the mill.

the area strongly suggests that some of the tailings are being transported from the mill site by the prevailing southerly winds. If calcium concentrations are sufficiently high in meteoric solutions (for example, if carbonate-bearing rocks are locally abundant), sulfuric acid from pyrite oxidation can react with the calcium to form gypsum $\left(\mathrm{CaSO}_{4} \cdot 2 \mathrm{H}_{2} \mathrm{O}\right)$. The spectral map of clays, carbonates, sulfates, and micas shows the occurrence of gypsum in the Bauer tailings, as well as jarosite that was detected in the $2-\mu \mathrm{m}$ spectral region (fig. 44).

Areas dominated spectrally by hematite and goethite were spectrally identified $\approx 3 \mathrm{~km}$ north-northwest of the Bauer tailings (fig. 31). Much of the hematite in this area forms dark reddish iron oxide coatings on rounded alluvial cobbles on the basin floor. Fine-grained pyrite has been found in the soils associated with these cobbles (Eric Dillenbeck, Colorado School of Mines, oral commun., 2002), suggesting that the iron oxides in this area are related to oxidation of fine-grained sulfide minerals transported northward from the Bauer Mill site by eolian processes. The area that was spectrally identified as containing goethite corresponds to an active gravel pit.
Two small deposits of mill tailings were spectrally identified at the mouth of Ophir Canyon (fig. 3), both of which are indicated on the USGS 1:24,000-scale quadrangle map (Ophir, Utah). The easternmost of the deposits, located on the north side of the creek $\approx 450$ m northeast of a small gravel pit (location: 40²1'31.67"N., 112 $17^{\prime} 59.74^{\prime \prime} \mathrm{W}$.), forms an arc $\approx 250 \mathrm{~m}$ in length around the remains of a tailings impoundment associated with a processing facility that is no longer in existence. Goethite and clay minerals (montmorillonite with minor occurrences of mixtures of kaolinite and illite/muscovite) were mapped in the deposits with the AVIRIS data (figs. 31 and 32). Patches of jarosite were observed in the deposits by field survey, and it is likely that some acidic solutions could be generated by reaction of meteoric water with these tailings. The second tailings deposit is between 500 and $800 \mathrm{~m}$ due west of the first one and was not field checked. In the second deposit, illite/ muscovite and mixtures of kaolinite and illite/muscovite, but no iron-bearing minerals, were mapped with the AVIRIS data (figs. 31 and 32). 


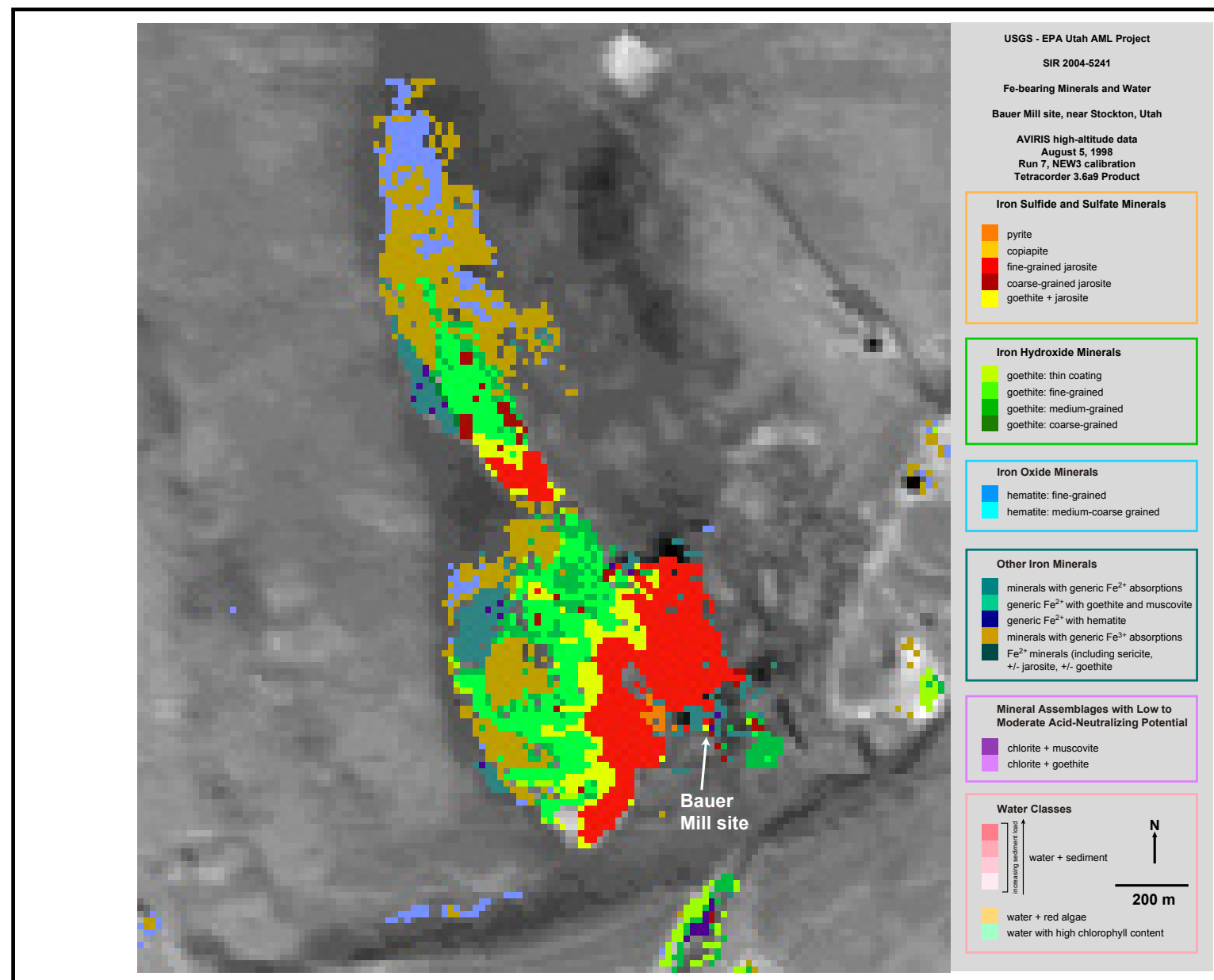

Figure 43. Enlargement of map of iron-bearing minerals and water (none detected) (fig. 31) over the site of the Bauer Mill near Stockton. Approximate location of mill: $40^{\circ} 28^{\prime} 16^{\prime \prime} \mathrm{N} ., 112^{\circ} 21^{\prime} 46^{\prime \prime} \mathrm{W}$.

View full-resolution file

\section{International Smelter and Refining Site}

There has been renewed interest in evaluating previous reclamation efforts at the International Smelter and Refining site. As growth from the town of Tooele expands eastward, identification of previously unknown potential sources of metals and evaluation of known sources becomes more critical. The soils of Pine Canyon (formerly Lincoln), directly down-gradient from the smelter site, have been most affected by any movement of metals and (or) airborne smelter emissions (U.S. Environmental Protection Agency, 2002b).

\section{Mineral-Distribution Patterns}

Down-gradient (northwest) from the smelter slag and tailings pile, the AVIRIS maps (figs. $\mathbf{4 5}$ and $\mathbf{4 6}$ ) do not indicate any substantial concentrations of minerals that might be associated with elevated metal levels. However, field observations in this area indicate that vegetation cover, mostly various types of grasses, is fairly dense even during dry periods. This vegetation may be masking mineral exposures. Areas in which iron-bearing minerals were detected by using the high-altitude AVIRIS data are indicative of revegetation failure. Soils from these areas should field checked for the presence of acid-producing sulfide or sulfate minerals and tested in the laboratory or with a field $\mathrm{XRF}$ unit for the presence of trace metals. Jarosite was spectrally identified in five pixels located just west (down-gradient) from a dike formerly used to impound tailings from the smelter (fig. 46). This jarosite was identified by the presence of a strong band near $2.27 \mu \mathrm{m}$ caused by a combination $\mathrm{OH}$ stretch and Fe-OH bend (Clark, 1999). Goethite and hematite were mapped in this area by using the $1-\mu \mathrm{m}$ spectral wavelength region (fig. 45). Although these pixels were not field checked, the presence of jarosite in this area is suggested by the presence of absorption bands near 0.43 and $2.27 \mu \mathrm{m}$ in the AVIRIS spectra.

Several kilometers west-northwest of the slag heaps, the AVIRIS mineral map also shows some small exposures of calcite and dolomite that may provide some natural ANP(fig. 46). A 


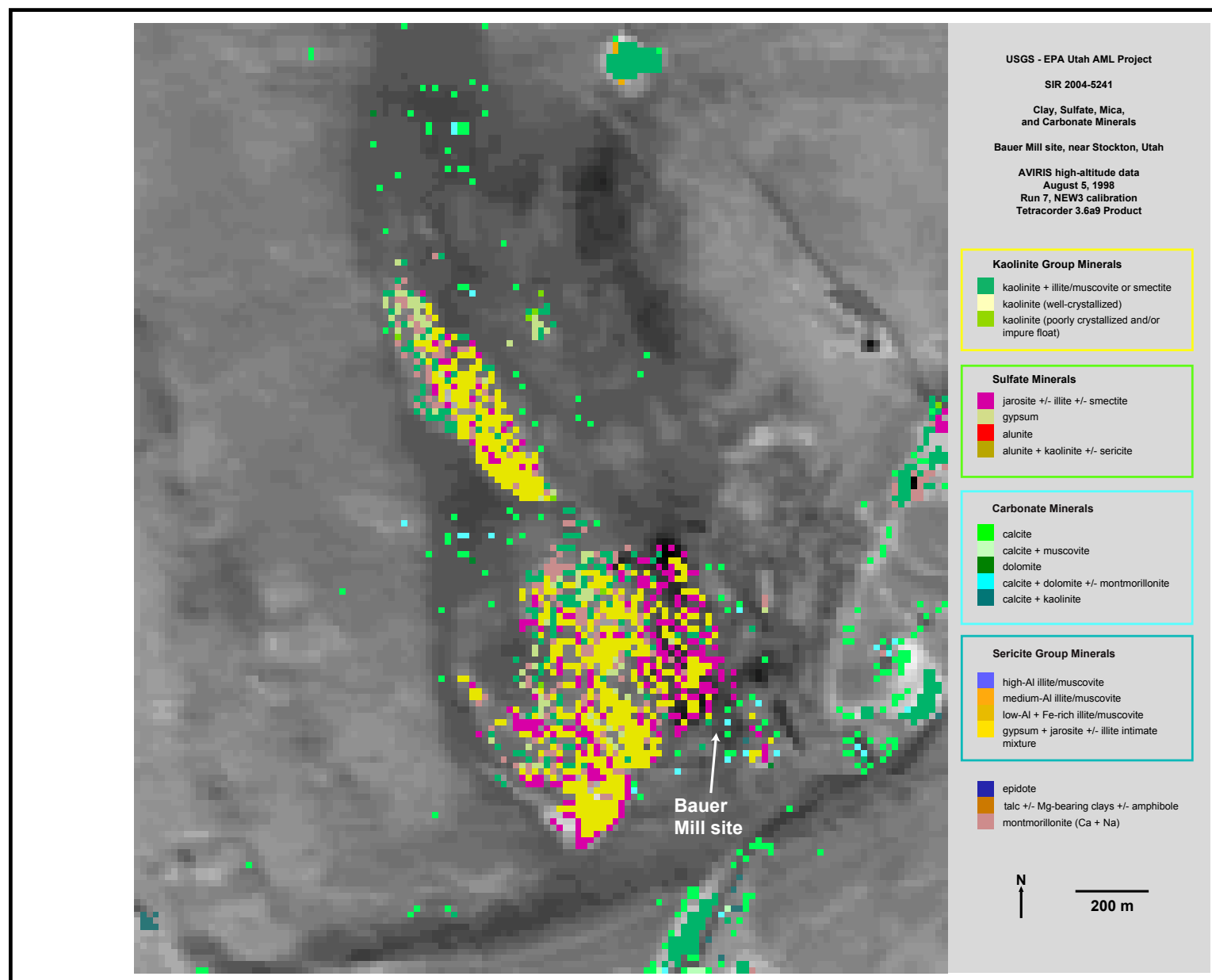

Figure 44. Enlargement of map of clay, carbonate, sulfate, and mica minerals (fig. 32) over the site of the Bauer Mill near Stockton. Approximate location of mill: $40^{\circ} 28^{\prime} 16^{\prime \prime} \mathrm{N}$., $112^{\circ} 21^{\prime} 46^{\prime \prime} \mathrm{W}$.

View full-resolution file

possible zone of argillic alteration occurs $3 \mathrm{~km}$ northeast of the smelter site, where the AVIRIS data analysis identified kaolinite and calcite + kaolinite. Kaolinite was spectrally identified along the flanks of the Oquirrh range just east of the smelter. Illite/ muscovite and mixtures of kaolinite + illite/muscovite were spectrally identified in abundance along the flanks of Pine Canyon to the southeast of the smelter site (fig. 3). Most of these mineral exposures on the mountain flanks east and southeast of the smelter occur in areas where vegetation has been denuded and (or) suppressed by smelter smokestack emissions. Some of the occurrences of kaolinite in these areas may be related to acid leaching by sulfuric acid in the smokestack emissions.

\section{Discussion}

In general, analysis of the high-altitude AVIRIS data covering the area of the International Smelter and Refining site did not identify any substantial evidence of minerals that may be associated with elevated metal concentrations, although vegetation may be masking surface minerals. It is possible that analysis of imaging spectrometer data with increased spatial resolution may reveal small areas of mineral concentrations that are unresolvable in the high-altitude data.

\section{The Tushar Mountains/Marysvale Region}

\section{Geologic Setting}

The Tushar Mountains/Marysvale region is $\approx 280 \mathrm{~km}$ south of Salt Lake City, Utah (see project index map at http:// speclab.cr.usgs.gov/earth.studies/Utah-1/utahproj_large.jpg). The region is underlain by a thick sequence of Paleozoic and Mesozoic sedimentary rocks that occurs widely throughout the Colorado Plateau. This sequence was mildly deformed into an 


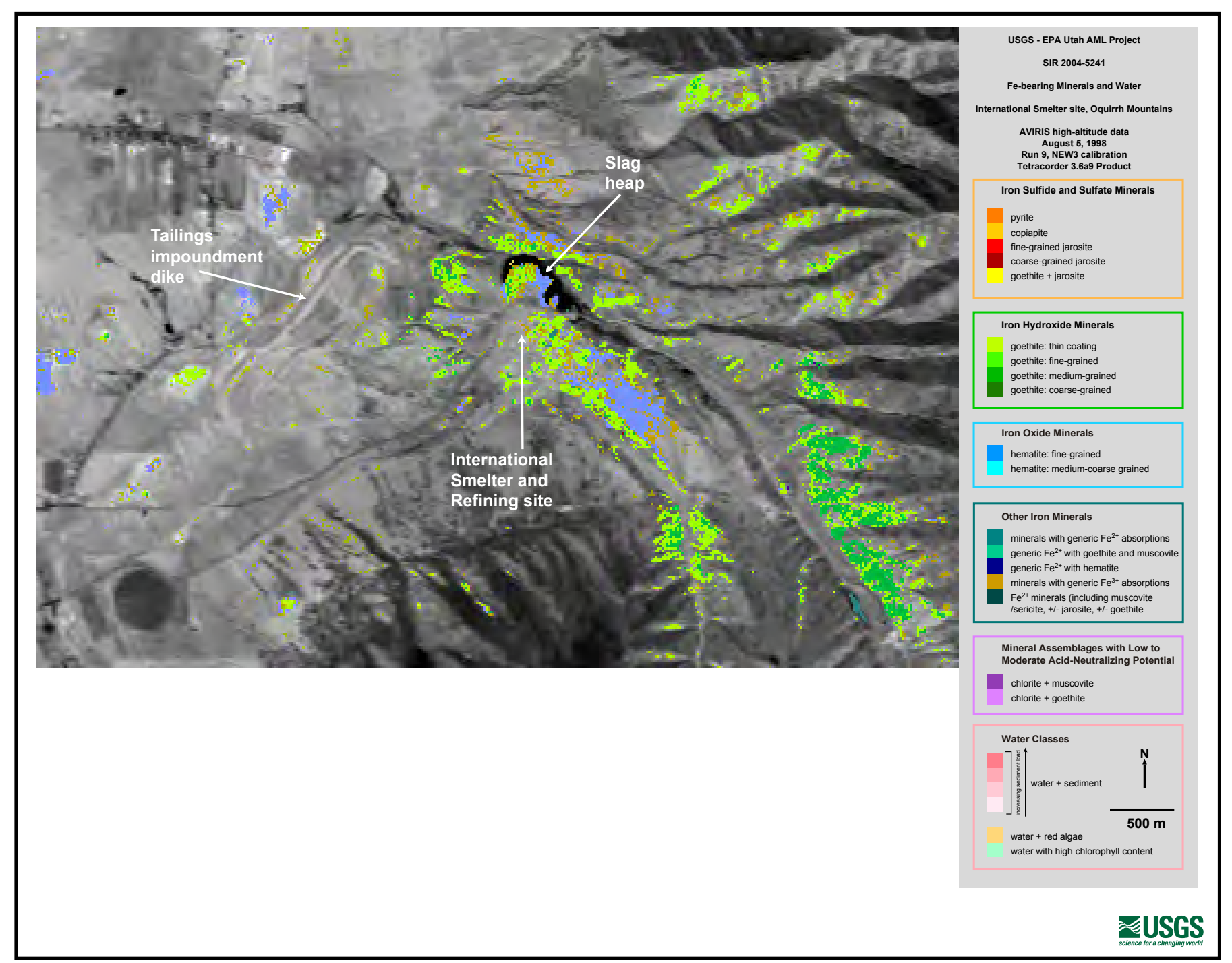

Figure 45. Enlargement of map of iron-bearing minerals and water (none conclusively detected) (fig. 33) over the International Smelter and Refining site east of Tooele. Approximate location of smelter site: $40^{\circ} 33^{\prime} 9.87^{\prime \prime} \mathrm{N} .1^{11} 2^{\circ} 13^{\prime} 29.67^{\prime \prime} \mathrm{W}$.

View full-resolution file

arch prior to $35 \mathrm{Ma}$ by compressional tectonic forces related to low-angle subduction several hundred kilometers to the south (Rowley and others, 1998). A large, east-trending batholith complex developed beneath the area that gave rise to extensive, primarily calc-alkaline, volcanism in the middle Tertiary, including the Miocene and Oligocene Bullion Canyon Volcanics exposed along Marysvale Canyon between the town of Marysvale and Interstate 70 . This magmatic episode culminated in the formation of the Monroe Peak caldera at $\approx 23 \mathrm{Ma}$ in the Sevier Plateau east of the Sevier River valley. With the onset of tectonic extension related to early Basin and Range deformation at $\approx 23-22 \mathrm{Ma}$, the volcanism became bimodal (alkali rhyolites and potassium-rich basalts), and a series of plutons intruded the older volcanic rocks from 23 to 14 Ma along a northeast trend; the oldest intrusions occur in the northeast, and the youngest occur beneath what is now Alunite Ridge and Deer
Trail Mountain (Cunningham and others, 1984). The Mount Belknap caldera formed in the north-central Tushar Mountains at $\approx 19 \mathrm{Ma}$, extruding the Joe Lott Tuff. These igneous rocks underlie most of the area covered by the 1998 AVIRIS data and make up the Marysvale volcanic field (Rockwell and others, 2000). The present topography was developed by Basin and Range extensional deformation that greatly accelerated at $\approx 8-7 \mathrm{Ma}$ and initiated the formation of the entrenched meanders along the Sevier River that now form Marysvale Canyon (Cunningham and others, 2005). Most mining in this region occurred in two general areas: on the eastern and northern flanks of the Tushar Mountains and in the Antelope Range 5 $\mathrm{km}$ north of the town of Marysvale (see project index map at http://speclab.cr.usgs.gov/earth.studies/Utah-1/utahproj_large. jpg for mine locations). 


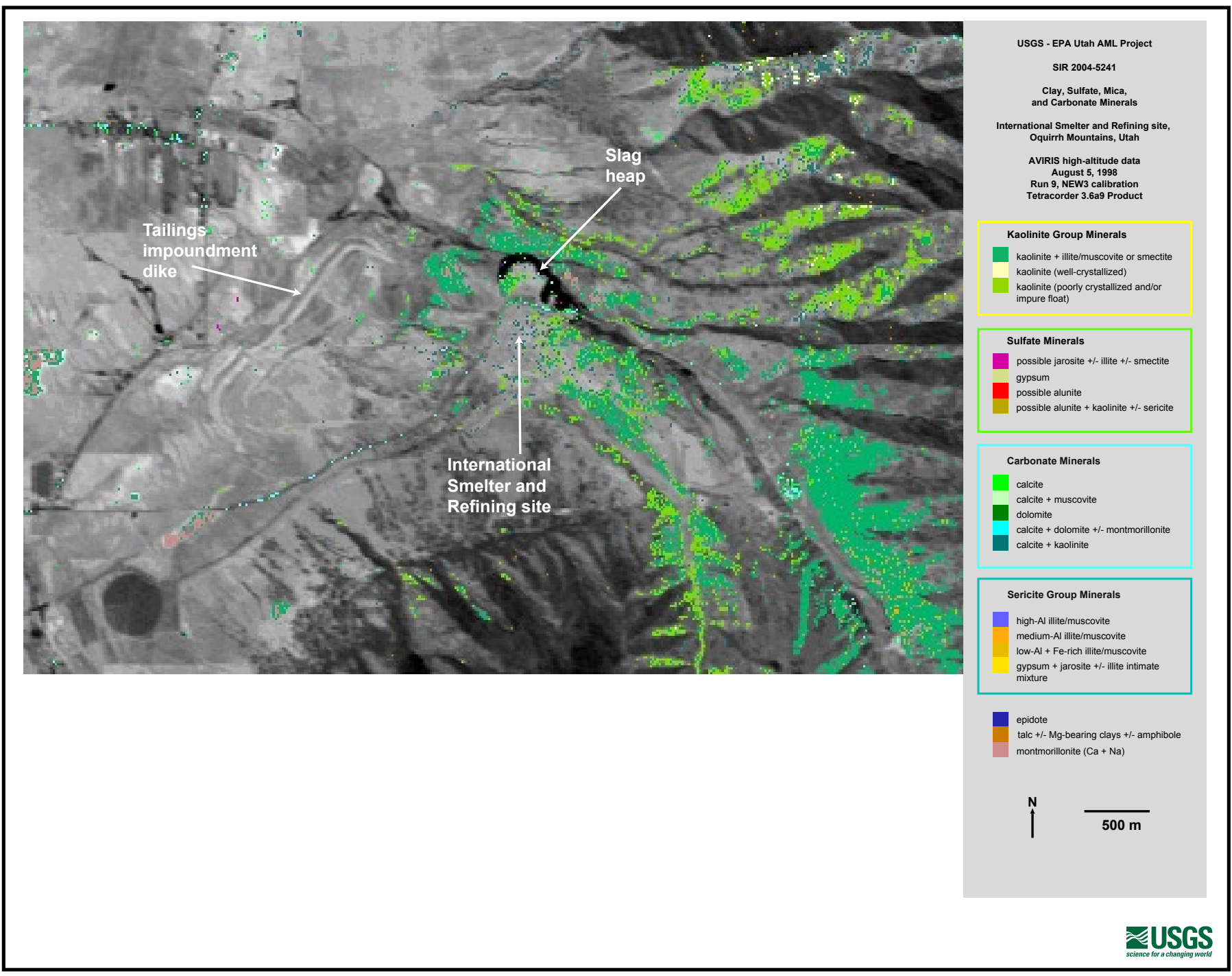

Figure 46. Enlargement of map of clay, carbonate, sulfate, and mica minerals (fig. 34) over the International Smelter and Refining site east of Tooele. Approximate location of smelter site: $40^{\circ} 33^{\prime} 9.87^{\prime \prime} \mathrm{N} ., 112^{\circ} 13^{\prime} 29.67^{\prime \prime} \mathrm{W}$.

View full-resolution file

\section{Ore Deposits and Mining History in the Eastern and Northern Tushar Mountains}

Deposits of vein alunite occur in the vicinity of Mount Brigham and Alunite Ridge (fig. 4) in the eastern Tushar Mountains (Cunningham and others, 1984). These deposits were formed around $14 \mathrm{Ma}$ in a high-temperature $\left(210-300^{\circ} \mathrm{C}\right)$ magmatic steam environment over a degassing magma (Cunningham and others, 1984; Rye and others, 1992). Mines on Alunite Ridge, such as the L and N, Sunshine, Christmas, Bradburn, and Mineral Products, operated during World War I and extracted alunite for the production of potassium sulfate fertilizer from open stopes, some of which are as much as $60 \mathrm{~m}$ deep. The locations of most of these mines are indicated on the mineral maps generated from high-altitude AVIRIS data (from AVIRIS run 11). The alunite was transported by aerial tram to a processing facility along the eastern foot of the range at the now-abandoned site of Alunite (fig. 4). Alunite has also been mined from alluvial and colluvial deposits along the eastern front of the Tushar Mountains. One such deposit is at the Close In alunite mine, which is $2 \mathrm{~km}$ north of the (new) Deer Trail mine (fig. 4).

Small deposits of gold and silver were mined between 1892 and 1937 from the Kimberly district on the northern flanks of the Tushar Mountains (fig. 4), where a small mill and associated tailings are located (Lindgren, 1906; Steven and Morris, 1983). Other small gold and silver mines are located along Deer Creek Canyon (for example, the Butler Beck mine). The gold and silver deposits in the northern Tushar Mountains occur in veins with quartz and carbonate minerals formed in the carapaces of quartz monzonite stocks about $23 \mathrm{Ma}$. 
The vein deposits were most likely formed from volatile-rich fluids during the later stages of differentiation of the intruding magmas. Open-pit mines from which kaolinite was extracted for fire brick are $3 \mathrm{~km}$ north of the Kimberly district near Red Narrows. Small mines in California Gulch (Copper Belt mine) and Revenue Gulch (Rainbow mine) between Pine and Beaver Creeks are most likely associated with juxtaposed $16 \mathrm{Ma}$ and 14 Ma mineralization from the zoned system of alteration, mineralization, and structures centered on Alunite Ridge $(\approx 14 \mathrm{Ma}$ ) and (or) slightly older rhyolitic intrusions near the Copper Belt mine (16.6 $\pm 0.7 \mathrm{Ma})$ and along Beaver Creek $(15.7 \pm 0.8 \mathrm{Ma})$ (Rowley and others, 1994).

For a period of over one hundred years (1878-1981), what is now called the Old Deer Trail mine, located $\approx 10 \mathrm{~km}$ south-southwest of the town of Marysvale (fig. 4), produced $\mathrm{Pb}, \mathrm{Zn}, \mathrm{Ag}, \mathrm{Au}$, and $\mathrm{Cu}$ from underground workings beneath Deer Trail Mountain. Sulfide minerals including galena, sphalerite, chalcopyrite, tetrahedrite, and pyrite occur in strata-bound replacement deposits (mantos) in carbonate rocks adjacent to feeder veins in faults and fractures. These deposits are similar in form and genesis to those of the Tintic and Park City mining districts. The deposits are thought to have formed at $14 \mathrm{Ma}$ and thus are nearly the same age as the alunite deposits high above on Alunite Ridge (Beaty and others, 1986). Wall-rock alteration adjacent to the base metal mantos includes sericitization and chloritization. Calc-silicate minerals, such as tremolite, chlorite, and epidote, formed by thermal metamorphism of siliceous dolomites and limestones, are also found and may be indicative of the presence of a hidden pluton. These minerals occur locally in strata-bound hornfels and are not associated with ore. Gold and silver deposits at the small mines along Pine Creek in Bullion Canyon (for example, the Bully Boy, Cascade, and Shamrock mines) and between this canyon and Mount Brigham (for example, the Wedge mine) are most likely related to the Alunite Ridge system (Cunningham and others, 1978).

The early mining activity in the Deer Trail area occurred at the Old Deer Trail and Lucky Boy mines located $2 \mathrm{~km}$ east-northeast of the summit of Deer Trail Mountain. An ore-processing mill and associated tailings-disposal ponds existed close to the mines. These ponds contain $>150,000$ tons of tailings (UNICO Incorporated, 2003). Mining activity is occurring at the present time (2004) at the (new) Deer Trail mine located $1.5 \mathrm{~km}$ southeast of the Old Deer Trail mine. In the 1950s, the PTH tunnel was constructed near the (new) Deer Trail mine in an attempt to reopen old gold workings. Renewed interest in mining ores from the (new) Deer Trail mine resulted in the construction of a mill in 2000-2001 nearby at the site of the now-abandoned mining town of Alunite.

\section{Ore Deposits and Mining History in the Antelope Range}

Deposits of gold, copper, replacement alunite, and hydrothermal uranium occur in the Antelope Range and surrounding area north and northeast of the town of Marysvale. Other than the uranium deposits, the ore deposits in the Antelope Range are related to the intrusion of a series of quartz monzonite stocks between 23 and $21 \mathrm{Ma}$. The stocks, often referred to as the Central intrusion, are now considered to be a composite intracaldera intrusion within the western section of the Monroe Peak caldera (Rowley and others, 2002). The quartz-carbonate veins carry deposits of copper at the Trinity mine and gold and silver at the Antelope and Yellow Cougar mines (fig. 8); these deposits are about the same age as the gold deposits in the Kimberly district and are thought to have formed in the carapaces of the nearby quartz monzonite stocks by similar processes (Charles G. Cunningham, USGS, oral commun., 2002). The intrusions set in motion multiple convecting hydrothermal systems that created discrete zones, or cells, of intense acid-sulfate alteration located at roughly even intervals around the peripheries of the stocks (Cunningham and others, 1984; Rockwell and others, 2000). These altered rocks - clearly visible in a map of mineral groups created from the Landsat 7 ETM+ data (fig. 47) - contain deposits of replacement alunite that were formed by near-surface, steam-heated hydrothermal processes at significantly lower temperatures $\left(100-170{ }^{\circ} \mathrm{C}\right)$ than the vein alunite on Alunite Ridge (Rye and others, 1992). Whereas the alunite deposits are temporally associated with the intrusion of the stocks, the deposits of natroalunite in the area were formed by hydrothermal reworking of the older replacement alunite by fluids associated with younger rhyolitic intrusions dated from 17 to $13 \mathrm{Ma}$ (Cunningham and others, 1984). Mines from which replacement alunite was extracted as an alternative source of aluminum during World War II include the White Horse mine (alunite), the Alum King mine and Big Star mines (natroalunite) within the Big Star cell, the Mary's Lamb mine and Yellow Jacket mine (mainly alunite with veins of natroalunite) within the Yellow Jacket cell, and the Al Kee Mee mine (natroalunite). Rich deposits of hematite formed in the upper parts of the Yellow Jacket cell were extracted for iron ore from small mines such as the Iron Cap (Callaghan, 1973).

After World War II, a mining boom occurred in the Antelope Range related to the exploitation of hydrothermal vein deposits of uranium, molybdenum, and fluorite associated with 18 Ma stocks located immediately to the south of the Central intrusion (Kerr and others, 1957; Cunningham and others, 1998). The area from which uranium was extracted is marked with a white " $\mathrm{X}$ " in figure 47. The ore-bearing veins are as much as $0.5 \mathrm{~m}$ in width and contain quartz, chalcedony, pyrite, fluorite $\left(\mathrm{CaF}_{2}\right)$, marcasite $\left(\mathrm{FeS}_{2}\right)$, pitchblende (the principal uranium oxide ore mineral), magnetite $\left(\mathrm{Fe}^{2+} \mathrm{Fe}_{2}^{3+} \mathrm{O}_{4}\right)$, hematite, and jordisite $\left(\mathrm{MoS}_{2}\right)$. Concentrations of pyrite, jordisite, and fluorite increase with depth in the ore-bearing veins. Pyrite makes up an estimated 15 percent of the vein-filling minerals in veins from the deepest parts of the mines. Pyrite gives way upward to hematite. Uranium content in the veins decreases with depth. Supergene alteration has produced secondary carbonate and gypsum as well as iron, manganese, and uranium oxides. 


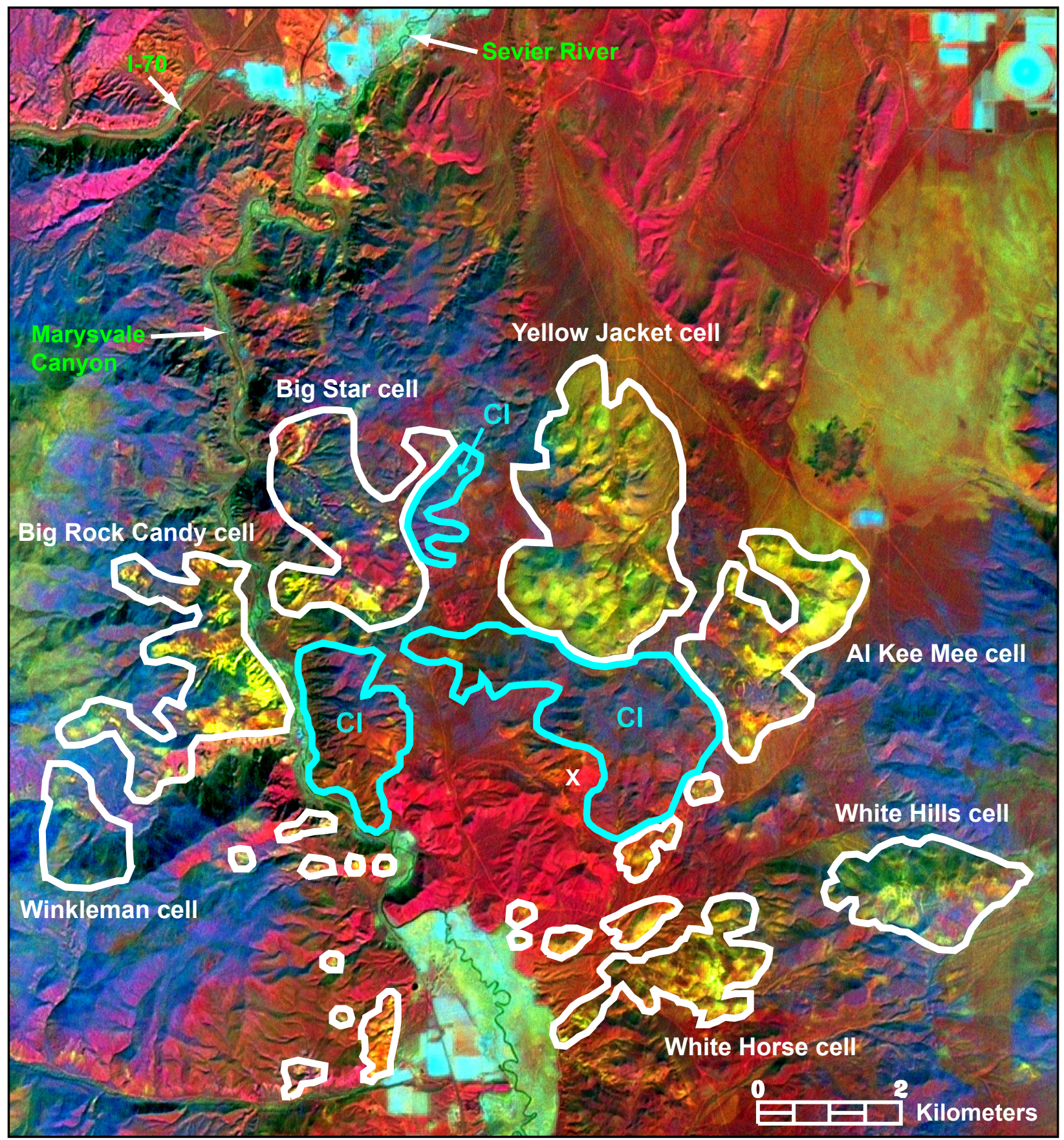

Figure 47. Landsat 7 ETM+ continuous-tone map of mineral groups and vegetation centered on the Antelope Range several kilometers north of Marysvale, Utah. Areas of intense argillic and advanced argillic hydrothermal alteration have been outlined in white. Data have been sharpened to $15-\mathrm{m}$ ground resolution by using the panchromatic band. $\mathrm{X}=$ uranium mining area. $\mathrm{Cl}=$ Central intrusion. Image center point: $38^{\circ} 31^{\prime} 26^{\prime \prime} \mathrm{N} ., 112^{\circ} 13^{\prime} 06^{\prime \prime} \mathrm{W}$.

Interpretation guide:

Red: rocks and soils bearing hematite and (or) other ferric iron minerals.

: $\mathrm{Fe}^{3+}+\mathrm{CSM}$ (mostly hydrothermal alteration).

Green: clays, sulfates, and micas (CSM), with possible bleaching.

Cyan: green, moist vegetation.

Blue: green, dry vegetation.

View full-resolution file 


\section{Mapping and Characterization of Mine Waste in the Tushar Mountains/Marysvale Region}

Material maps generated from the high- and low-altitude data are shown in figures 48-53. Jarosite-bearing rocks were spectrally identified at only one mine in the entire Tushar Mountains/Marysvale region. At this mine, $1 \mathrm{~km}$ west-southwest of the (new) Deer Trail mine, goethite and six pixels of coarsegrained jarosite were mapped. This occurrence of jarosite has not been field verified because it is located on private property. AVIRIS spectra sampled from these pixels show strong electronic absorptions near $1.00 \mu \mathrm{m}$ that are most likely related to ferric iron, but spectral features diagnostic of jarosite at 0.43 and $2.27 \mu \mathrm{m}$ are not obvious. Waste-rock piles at most of the gold or silver mines in the eastern Tushar Mountains were not effectively characterized with the high-altitude AVIRIS data because they are too small and (or) are obscured by vegetation.

The replacement alunite deposits in the Antelope Range were mined via surface workings, all of which are abandoned. These workings contain hematite, alunite, local hypogene jarosite, and various clay minerals on the surface. No oxidizing sulfide minerals are present on the surface at these mines, as sulfide minerals (mainly pyrite) occur only in the propylitically altered feeder zones of the hydrothermal systems that underlie the alunite-bearing rocks (see ore-formation model in section on Unmined Mineralized Rocks, below). Mining has fractured the alunite- and jarosite-bearing rocks and increased their exposed surface area. Where jarosite is present, this increased exposure makes it more likely that meteoric solutions infiltrating these rocks will become mildly acidified.

Waste rock associated with uranium mining (fig. 54) is characterized by goethite, montmorillonite (smectite), illite/ muscovite, and minor amounts of kaolinite (figs. 50 and 51). Several pixels of coarse-grained goethite with possible trace amounts of jarosite were spectrally identified in this area. Although pyrite is present in the uranium-, molybdenum-, and fluorite-bearing ore deposits, the pyrite is not present in large amounts in the waste-rock piles, which are composed mainly of the weakly altered intrusive rocks (quartz monzonite and fine-grained granite) that hosted the vein deposits. A suite of uranium minerals was not included in the USGS spectral library used by the Tetracorder mapping software at the time of this study; thus, the AVIRIS data were not queried for the presence of uranium-bearing minerals. It is unlikely that uranium-bearing minerals in the waste rock could be directly detected with high-altitude AVIRIS data.

An occurrence of hematite, goethite, and alunite was mapped with the AVIRIS data on the west bank of the Sevier River immediately east of the town of Marysvale (fig. 51). The pixels mark the site of a loading area where alunitic ores from local mines were loaded into trucks via a large drive-in hopper.

Small occurrences of goethite were detected at the sites of the Old and (new) Deer Trail mines (fig. 50). This iron-bearing material at the site of the Old Deer Trail mine may be waste rock and (or) tailings material from the mine and mill that used to exist there, but the area was not field checked as it lies on private property. At the (new) Deer Trail mine, the goethite occurs in very low spectral abundance and corresponds to waste rock dumped immediately east of the main mine portal. Talc $\left(\mathrm{Mg}_{3} \mathrm{Si}_{4} \mathrm{O}_{10}(\mathrm{OH})_{2}\right)$ and (or) tremolite $\left(\square \mathrm{Ca}_{2} \mathrm{Mg}_{5} \mathrm{Si}_{8} \mathrm{O}_{22}(\mathrm{OH})_{2}\right)$ were also detected with the AVIRIS mapping in this waste rock at the (new) Deer Trail mine (fig. 51). Talc and tremolite commonly occur together and are difficult to distinguish through the use of spectroscopic data having a sampling interval and bandpass similar to those of AVIRIS; thus both minerals were included on the explanations of the mineral maps. The presence of talc and calcite in the waste rock was confirmed via laboratory spectroscopy and XRD analysis (appendix table A3, sample MV-5-02-3). Although talc itself has not been documented at the Deer Trail deposit, its occurrence is to be expected, as talc and tremolite are the first minerals to form in the low-grade thermal metamorphism of siliceous dolomites (Winkler, 1979). Tremolite-bearing hornfels has been identified at the deposit, which is hosted by limestones, dolomites, and calcareous shales (Beaty and others, 1986). Talc dominates the laboratory and AVIRIS spectra of the waste rock in the 2.0- to 2.5- $\mu \mathrm{m}$ region, although calcite was found to be present in significantly greater abundance ("major," > 25 percent) than talc ("minor," 5-25 percent) by the XRD analysis. Talc was also found to dominate the AVIRIS spectrum of waste rock from carbonate-hosted polymetallic manto deposits in the Park City mining district, Utah, in which talc and calcite were present in approximately equal amounts along with trace dolomite (Rockwell and others, 1999; sample PC99-1G in Rockwell, 2002). The data presented here suggest that acid-buffering minerals are present in abundance in the waste rock at the (new) Deer Trail mine.

The tailings located in the Kimberly district along Mill Creek (fig. 4) contain minor amounts of goethite and clay minerals. Spectra of the tailings extracted from the high-altitude AVIRIS data showed weak absorptions at $2.2 \mu \mathrm{m}$ indicative of phyllosilicates (most likely montmorillonite), but these features were too weak to be identified by the Tetracorder spectral analysis. No spectral evidence of significant amounts of oxidizing sulfide minerals was found in this area.

\section{Unmined Mineralized Rocks with Acid-Producing Potential (APP)}

\section{Occurrences of Acid-Sulfate Alteration in the Tushar Mountains and Antelope Range}

Unmined areas of altered, mineralized rock are clearly identified on the AVIRIS mineral maps. Altered rocks in these areas are characterized by alunite, jarosite, clay minerals, and micas formed by intense acid-sulfate hydrothermal alteration in the Miocene Epoch at $\approx 23-14$ Ma (Cunningham and others, 1984, 2005). Prominent alunite-bearing mineralized areas include (1) altered rocks associated with the replacement alunite deposits that occur around the peripheries of quartz monzonite intrusive rocks in the Antelope Range (figs. 4, 47, and 51); (2) argillic alteration along the northeast-striking trend between 
the Antelope Range and Deer Trail Mountain associated with intrusions dated between 21 and $16 \mathrm{Ma}$; (3) argillic and advanced argillic alteration zones in the northern Tushar Mountains north of Deer Creek Canyon and east of the Kimberly district (fig. 4) within the Joe Lott Tuff Member of the Mount Belknap Volcanics (just north of the northern rim of the topographic wall of the Mount Belknap caldera); and (4) vein alunite deposits and associated wall-rock alteration in the Alunite Ridge-Deer Trail Mountain area $10 \mathrm{~km}$ southwest of the town of Marysvale (fig. 4). The alunite deposits spectrally identified in the northern Tushar Mountains east of the Kimberly district are interpreted as low-temperature replacement deposits similar to those in the Antelope Range. These deposits were most likely formed by convecting, lowtemperature hydrothermal solutions around the peripheries of local quartz monzonite stocks emplaced at $\approx 23 \mathrm{Ma}$. Although alunite itself has not been demonstrated by leaching studies to have significant APP, these replacement alunite deposits typically overlie pyrite-bearing feeder zones that, when exposed, can have very significant APP (Cunningham and others, 2005). Therefore, pyrite below these alunite deposits may lower the "background" $\mathrm{pH}$ value of the natural water in these watersheds.

\section{Occurrences of Jarosite in the Antelope Range and Surrounding Area}

Several occurrences of nonanthropogenic jarosite were mapped with the AVIRIS data in areas underlain by altered rock. X-ray diffraction (XRD) analysis of rocks from some of these areas confirmed the presence of jarosite (appendix table A3). In the replacement alunite deposits of the Antelope Range area, jarosite occurs with other acid-sulfate alteration minerals in distinct patterns of horizontal and vertical zoning related to the processes of both genesis and weathering of the deposits. Figure 55 illustrates these spatial patterns of mineral zoning within a genetic model for such hydrothermal systems that refines the model proposed by Cunningham and others (1984). Pyrite occurs in the sulfidized, propylitically altered feeder zones of the systems that were formed in reducing conditions well below the paleo-ground-water table and the zone of boiling. The alunite was formed at and just below the paleo-groundwater table by steam-heated oxidation of $\mathrm{H}_{2} \mathrm{~S}$ in conjunction with boiling within the rising arms of the convecting hydrothermal plumes (Cunningham and others, 2005). Hypogene jarosite was formed in very low $\mathrm{pH}$ conditions within the paleo-vadose zone immediately above the paleo-ground-water table and the alunite. Hematite was formed mostly above the jarosite from fluids with reduced sulfate activities. Opaline sinter terraces formed near the paleo-ground surface and locally contain siliceous breccias created by hydrothermal explosions; the breccias mark the locations of fumaroles. The deposits of silica are erosion resistant and are locally found at the peaks of hills within the Antelope Range, most notably in the uppermost parts of the Yellow Jacket cell. Erosion related to the downcutting of the Sevier River has exposed the pyrite-bearing feeder zones of the Big Rock Candy, Big Star, and White Horse cells and has removed most, if not all, of the hypogene jarosite from these cells.

Pyrite does not occur intimately with the alunite or with the hypogene jarosite, hematite, and silica (Willard and Proctor, 1946; Kerr and others, 1957; Rye and Alpers, 1997). This finding was corroborated by the fact that XRD analyses of the coarse-grained, hypogene jarosite from the Yellow Jacket cell did not detect the presence of pyrite (appendix table A3, samples SW IH B1, SW IH B2, and MV01-1). Conversely, the fine-grained coatings of natrojarosite that occur in several of the hydrothermal cells in the Antelope Range are directly associated with the supergene oxidation and weathering of pyrite-bearing rocks from the feeder zones.

The Tetracorder-based spectral mapping was able to differentiate jarosites formed under different geochemical conditions within the hydrothermal systems associated with the replacement alunite deposits. By using the high-altitude AVIRIS data, coarse-grained, hypogene jarosite co-occurring

Figure 48 (page 62, left). Map of iron-bearing minerals in the central Tushar Mountains, Utah, generated from run 11 of the high-altitude AVIRIS data. The Alunite Ridge-Deer Trail Mountain area and the Kimberly mining district are shown. On this map, two spectrally identified mineral types are displayed through the use of continuous stretches (marked " $C$ " in color key; see Spectral Analysis chapter) in which the brightness level of the color selected for that mineral type decreases with decreasing spectral fit $\times$ depth of the material identification.

View full-resolution file

Figure 49 (page 62, right). Map of clay, carbonate, sulfate, mica, and hydrous silica minerals in the central Tushar Mountains, Utah, generated from run 11 of the high-altitude AVIRIS data. The Alunite Ridge-Deer Trail Mountain area and the Kimberly mining district are shown.

View full-resolution file

Figure 50 (page 63, left). Map of iron-bearing minerals and water in the eastern Tushar Mountains and Antelope Range, Utah, generated from run 10 of the high-altitude AVIRIS data. The area from which uranium was extracted is shown. On this map, two spectrally identified mineral types are displayed through the use of continuous stretches (marked " $C$ " in color key; see Spectral Analysis chapter) in which the brightness level of the color selected for that mineral type decreases with decreasing spectral fit $\times$ depth of the material identification.

View full-resolution file

Figure 51 (page 63, right). Map of clay, carbonate, sulfate, mica, and hydrous silica minerals in the eastern Tushar Mountains and Antelope Range, Utah, generated from run 10 of the high-altitude AVIRIS data. The town of Marysvale and the area from which uranium was extracted are shown.

View full-resolution file 

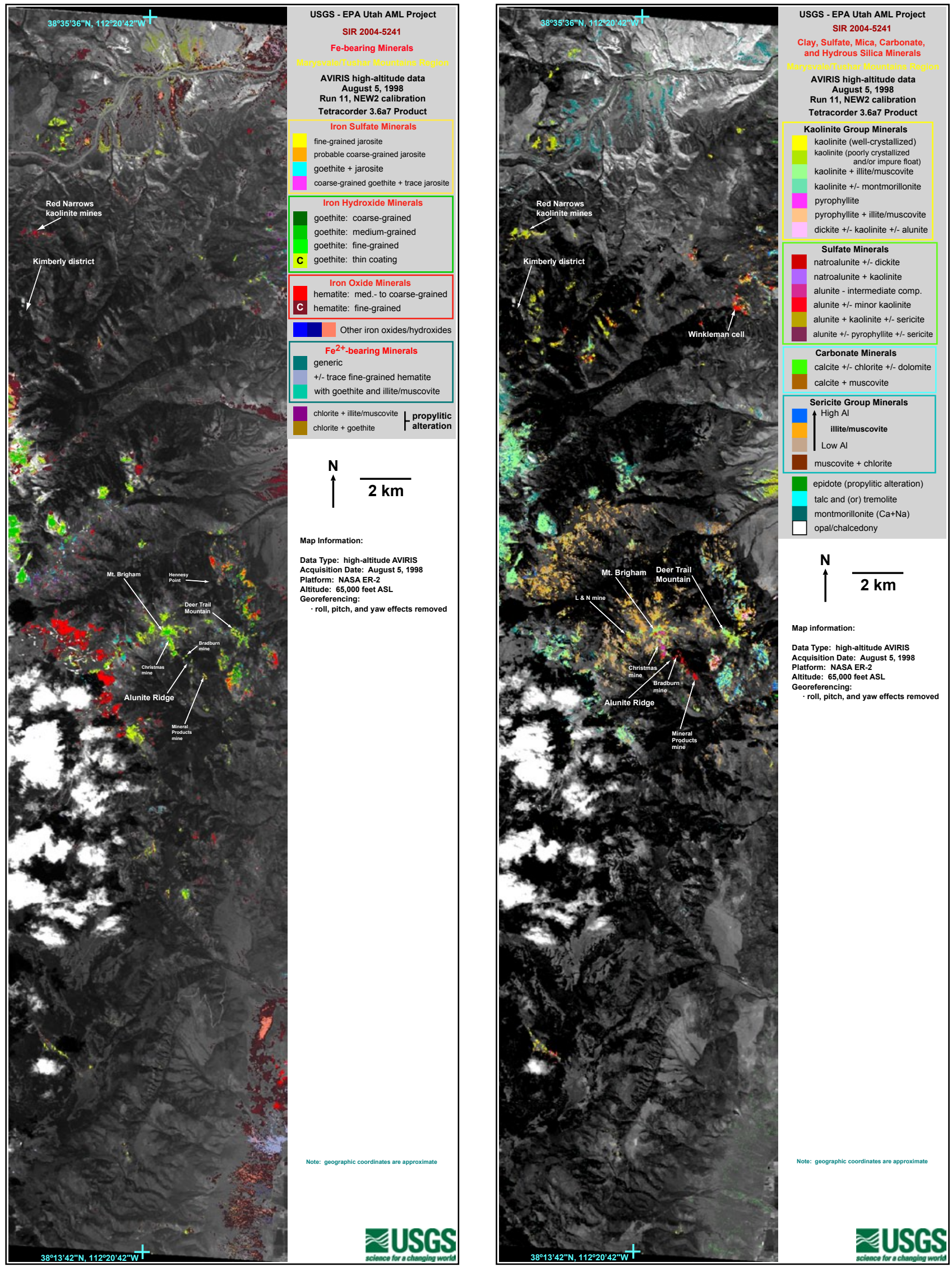

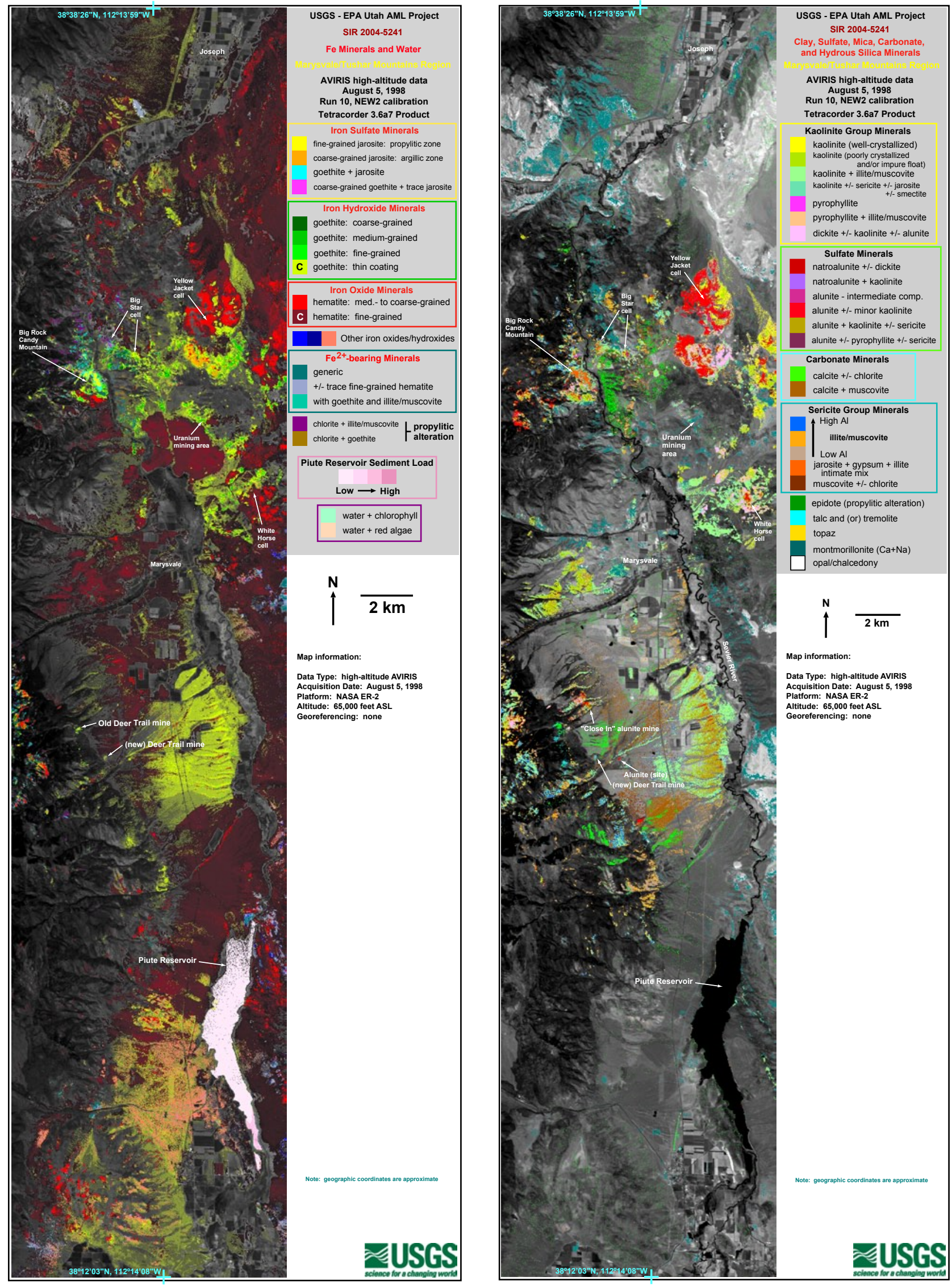


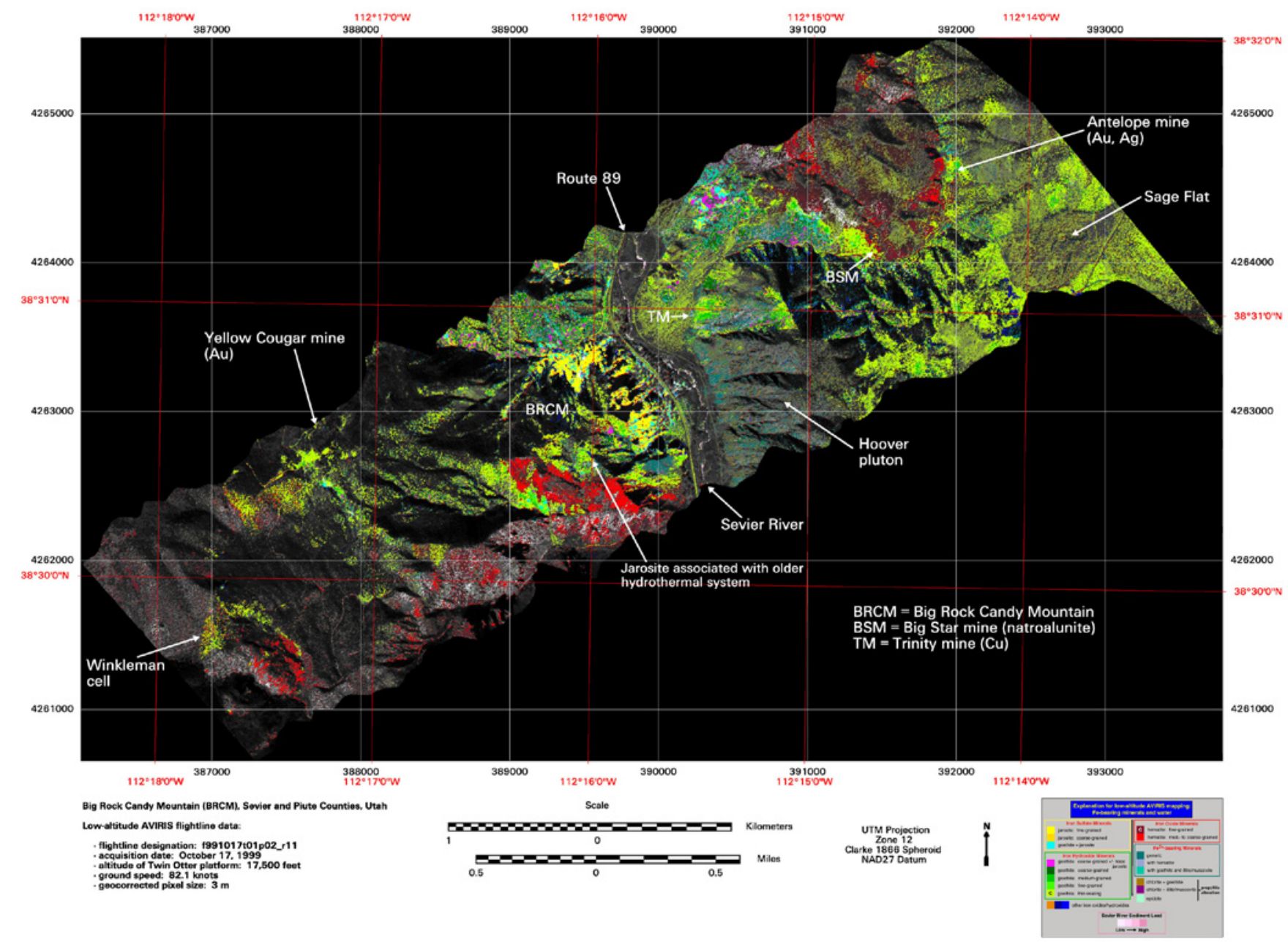

Figure 52. Map of iron-bearing bearing minerals and water in the Big Rock Candy Mountain area of the Marysvale volcanic field, Utah, produced from the low-altitude AVIRIS data. On this map, two spectrally identified mineral types are displayed through the use of continuous stretches (marked " $C$ " in color key; see Spectral Analysis chapter) in which the brightness level of the color selected for that mineral type decreases with decreasing spectral fit $\times$ depth of the material identification.

View full-resolution file

with alunite in advanced argillic alteration zones of the Yellow Jacket cell was differentiated spectrally from fine-grained coatings of supergene natrojarosite found in the pyrite-rich, propylitically altered feeder zones where exposed on Big Rock Candy Mountain (fig. 50; Rockwell and others, 2000). In the White Horse cell, however, this spectral differentiation was imperfect, as the AVIRIS mapping detected both coarse- and fine-grained jarosite within pyrite-bearing rocks of the sulfidized feeder zone that are coated with supergene jarosite (jarosite composition has not been determined, although XRD analysis detected jarosite and not natrojarosite). Compared to Big Rock Candy Mountain, the White Horse area has undergone much less erosion and therefore has relatively low relief and far less exposed pyrite-bearing rock. The relatively limited exposure of pyrite-bearing rock has led to reduced acid generation and rates of jarosite development. These factors have allowed thicker coatings of goethite to develop from the jarosite, resulting in mixtures of jarosite and goethite. Analysis of the high-altitude AVIRIS data detected two pixels of a goethite + jarosite areal mixture on the northern flanks of the White Horse deposit (fig. 50). The areas identified as coarse-grained jarosite near this deposit most likely represent mixtures of goethite and jarosite that contain slightly more goethite than the areas in which the goethite + jarosite mixture was directly detected. Areas spectrally identified as goethite surround the areas identified as coarse-grained jarosite. Throughout the Antelope Range and Tushar Mountains, AVIRIS pixels directly detected as a goethite + jarosite areal mixture were identified only within areas where active pyrite oxidation is occurring in the propylitically altered feeder zones of the hydrothermal cells.

At the scale of high-altitude AVIRIS pixels, variations in the VIS and NIR spectra of the hypogene and supergene jarosites in the Antelope Range most likely relate to increased amounts of goethite content and (or) coarser grain sizes in the hypogene jarosite (Rockwell and others, 2000). The fine-grained, supergene natrojarosite was a spectral match to a reference 


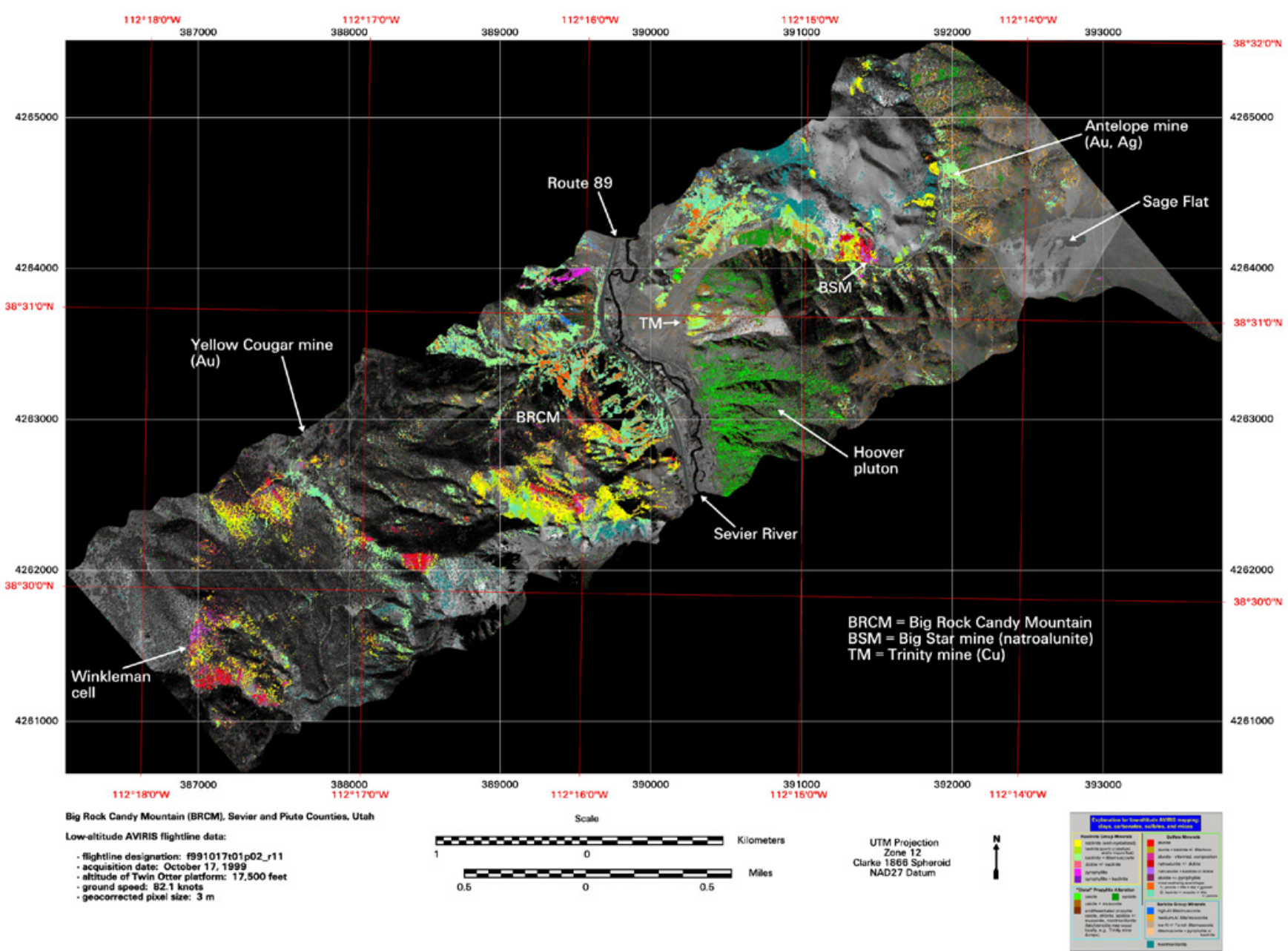

Figure 53. Map of clay, carbonate, sulfate, and mica minerals in the Big Rock Candy Mountain area of the Marysvale volcanic field, Utah, produced from the low-altitude AVIRIS data.

View full-resolution file

spectrum of synthetic jarosite (sample GDS99, Clark, Swayze, Wise, and others, 2003), and the coarse-grained, hypogene jarosite was a spectral match to a reference spectrum of a jarosite coating on a rock rich in quartz and muscovite with additional coatings of what appear to be manganese-iron oxides (sample BR93-34A2, Clark, Swayze, Wise, and others, 2003). Figure 29 shows spectra of jarosites from the Tintic mining district that exhibit the VIS/NIR spectral variations between the reference jarosites. The spectrum of sample TN00-21 is similar to the spectrum of reference sample BR93-34A2, and the spectrum of sample TN00-17b closely resembles that of reference sample GDS99. The spectrum of sample TN00-21 (and thus the spectrum of reference sample BR93-34A2) has similarities in the VIS/NIR to goethite, most notably a prominent feature at $0.66 \mu \mathrm{m}$. The continuum-removed centers of the primary electronic crystal field absorption features caused by ferric iron in the GDS99 and BR93-34A2 jarosite reference spectra are $0.9219 \mu \mathrm{m}$ and $0.9466 \mu \mathrm{m}$, respectively. The continuumremoved band center of the feature in a reference spectrum of goethite is $0.9475 \mu \mathrm{m}$ (sample WS222, Clark, Swayze, Wise, and others, 2003). The reference spectrum of the BR93-34A2 jarosite is thus similar to that of goethite in some respects, suggesting that this jarosite sample contains some amorphous goethite and (or) that it is characterized by coarser jarosite crystal sizes than the GDS99 jarosite. As no goethite was detected in the BR93-34A2 jarosite sample with XRD, pixels matching this reference jarosite are labeled as coarse-grained jarosite on the maps of iron-bearing minerals. It is unknown whether the coatings of "manganese-iron oxides" present in the BR93-34A2 jarosite reference sample are affecting its spectral shape.

Field samples of the hypogene and supergene jarosites from the Antelope Range area were analyzed in the laboratory by using VIS-NIR-SWIR spectroscopy and a scanning electron microscope (SEM) to determine goethite content and crystal grain size. Figure $\mathbf{5 6}$ shows laboratory spectra of these jarosite-bearing rocks. Both of these spectra were convolved to the wavelength and bandpass characteristics of the 1998 AVIRIS data and analyzed by the Tetracorder expert system to determine mineral composition. Mixtures of goethite and 


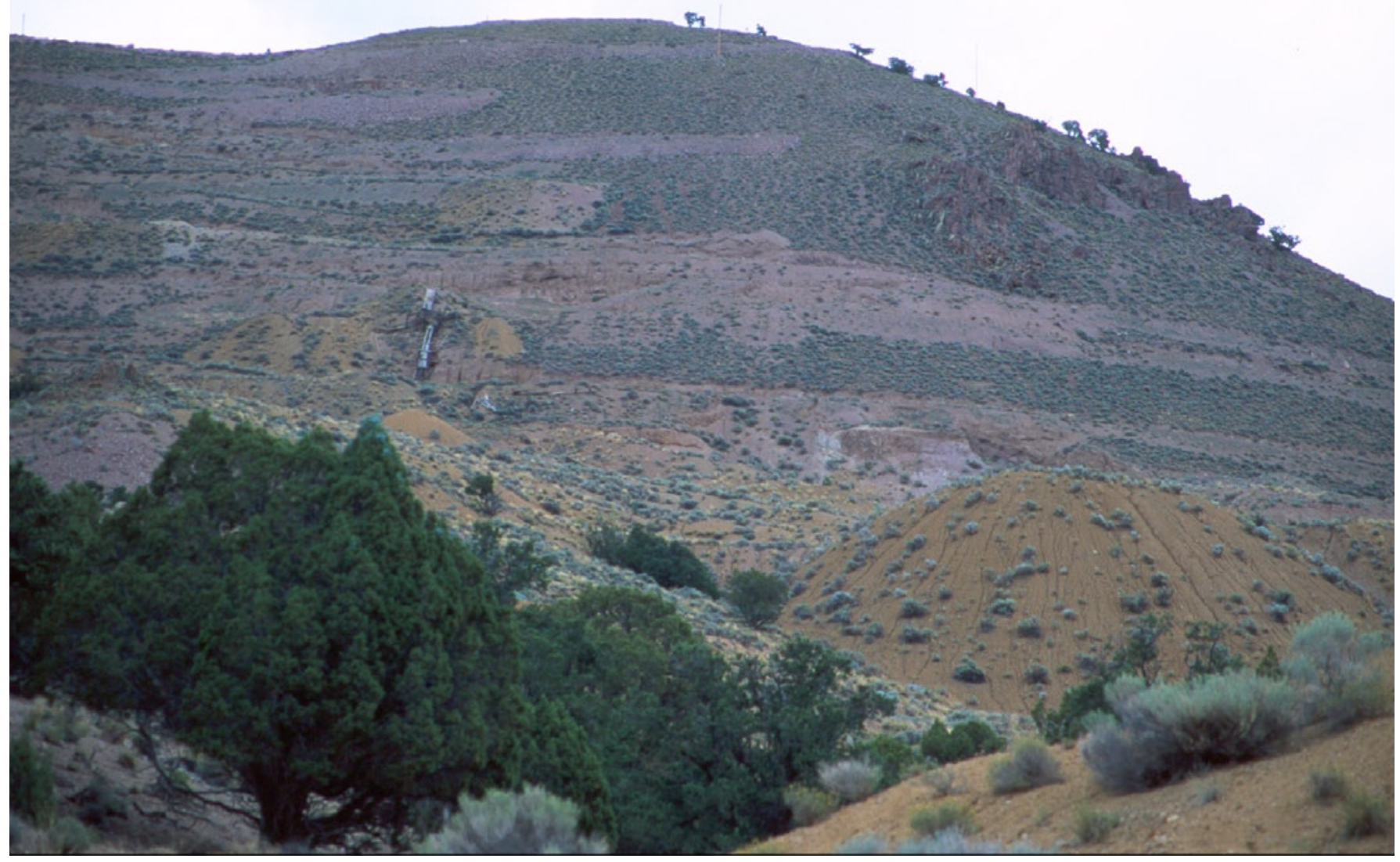

Figure 54. View of the area from which uranium was extracted, looking east toward Jungfrau Peak with goethite-coated waste-rock piles in foreground. The remains of an ore chute are visible just left of center near the site of an abandoned mine shaft.

jarosite were identified in both spectra on the basis of VIS and NIR characteristics. Sample BRCM-1 was collected from the lower northeastern flanks of Big Rock Candy Mountain in an area mapped as a goethite + jarosite mixture with the AVIRIS data (appendix table A3 and figs. $\mathbf{5 0}$ and 52). SEM analysis of sample BRCM-1 identified coatings of amorphous iron oxides and hydroxides around crystals of natrojarosite and other minerals, as well as large crystals of gypsum. The spectrum of sample MV01-1 shown in figure $\mathbf{5 6}$ was acquired from a fresh surface from the southwestern flanks of the Yellow Jacket cell on which abundant jarosite is present. Laboratory spectra (not shown) of weathered surfaces from sample MV01-1 were identified by single-spectrum Tetracorder analysis as thin coatings of goethite, although the presence of jarosite was apparent from the absorption feature at $2.27 \mu \mathrm{m}$. Thin coatings of goethite were identified in the AVIRIS spectra around most pixels of coarse-grained jarosite in the Yellow Jacket cell (fig. 50). SEM analyses also showed that the crystal sizes of hypogene jarosite in sample MV01-1 range from 5 to 10 $\mu \mathrm{m}$, whereas those of secondary natrojarosite in sample BRCM-1 range from 2 to $5 \mu \mathrm{m}$. These findings confirmed that (1) although goethite is present in both the supergene and hypogene jarosites, it is more abundant in the rocks bearing hypogene jarosite and affects their VIS/NIR spectral shape more significantly and (2) the grain sizes of the hypogene jarosite are coarser than those in the coatings of supergene natrojarosite. Active modern pyrite oxidation on the flanks of Big Rock Candy Mountain is creating abundant natrojarosite, and goethite is generally less abundant there than in the pyritefree zones of ancient advanced argillic alteration in the Yellow Jacket cell.

In the Tintic mining district, similar spectral variations were used to differentiate fine-grained coatings of jarosite in waste-rock piles at mine sites from unmined, nonanthropogenic occurrences of coarse-grained jarosite within zones of advanced argillic alteration (fig. 29). In the Tintic district, all of the spectrally identified jarosite was derived from supergene oxidation of pyrite. Both the coarse-grained hypogene jarosite associated with the replacement alunite deposits in the Antelope Range and the coarse-grained supergene jarosite associated with rocks bearing alunite and pyrite in the Tintic district have remained stable even though they have been exposed to natural weathering for an extended time. The fact that jarosite remains on the surface and has not broken down to ferrihydrite or goethite may be due to its stabilization by the near-neutral $\mathrm{pH}$ conditions maintained by high concentrations of $\mathrm{K}^{+}$and $\mathrm{SO}_{4}^{2-}$ (both of which are locally present in abundance within the alunite-bearing rocks) or to slow reaction kinetics 
(Swayze and others, 2000). However, abundant goethite was detected with the AVIRIS data around most occurrences of jarosite in both study areas, which most likely indicates that some breakdown of jarosite has occurred.

The laboratory-derived spectra show subtle variations in the VIS and NIR regions (fig. 56); these variations are due, in part, to the relative amounts of solid-solution substitution of sodium and potassium in the jarosite crystal structures. These spectral variations relating to composition are not reliably discernible with AVIRIS data in the VIS and NIR regions. The principal distinguishing features of these spectra are the represented mineral assemblages themselves. The hypogene jarosite always occurs intimately with alunite (that is, as crystals intergrown with alunite) and (or) in proximity to alunite, whereas the supergene natrojarosite occurs as fine-grained coatings with illite and gypsum not spatially associated with alunite. At Big Rock Candy Mountain, the rocks of the pyrite-bearing feeder zone exposed on the mountain flanks are crosscut with fractures filled with coarsely crystalline gypsum (as selenite). Isotopic studies of this gypsum indicate that it is mostly of supergene origin and that its sulfate was originally in an aqueous solution derived from both dissolution of overlying alunite and the oxidation of pyrite (Cunningham and others, 2005). Because of intimate mixtures with other minerals, the spectral variations between jarosite and natrojarosite in the SWIR region $(2.1-2.3 \mu \mathrm{m})$ are masked in the spectra shown in figure $\mathbf{5 6}$ and thus cannot be used to differentiate the two types of jarosite. However, these diagnostic SWIR features can be observed through laboratory spectral analysis of samples that have been crushed,

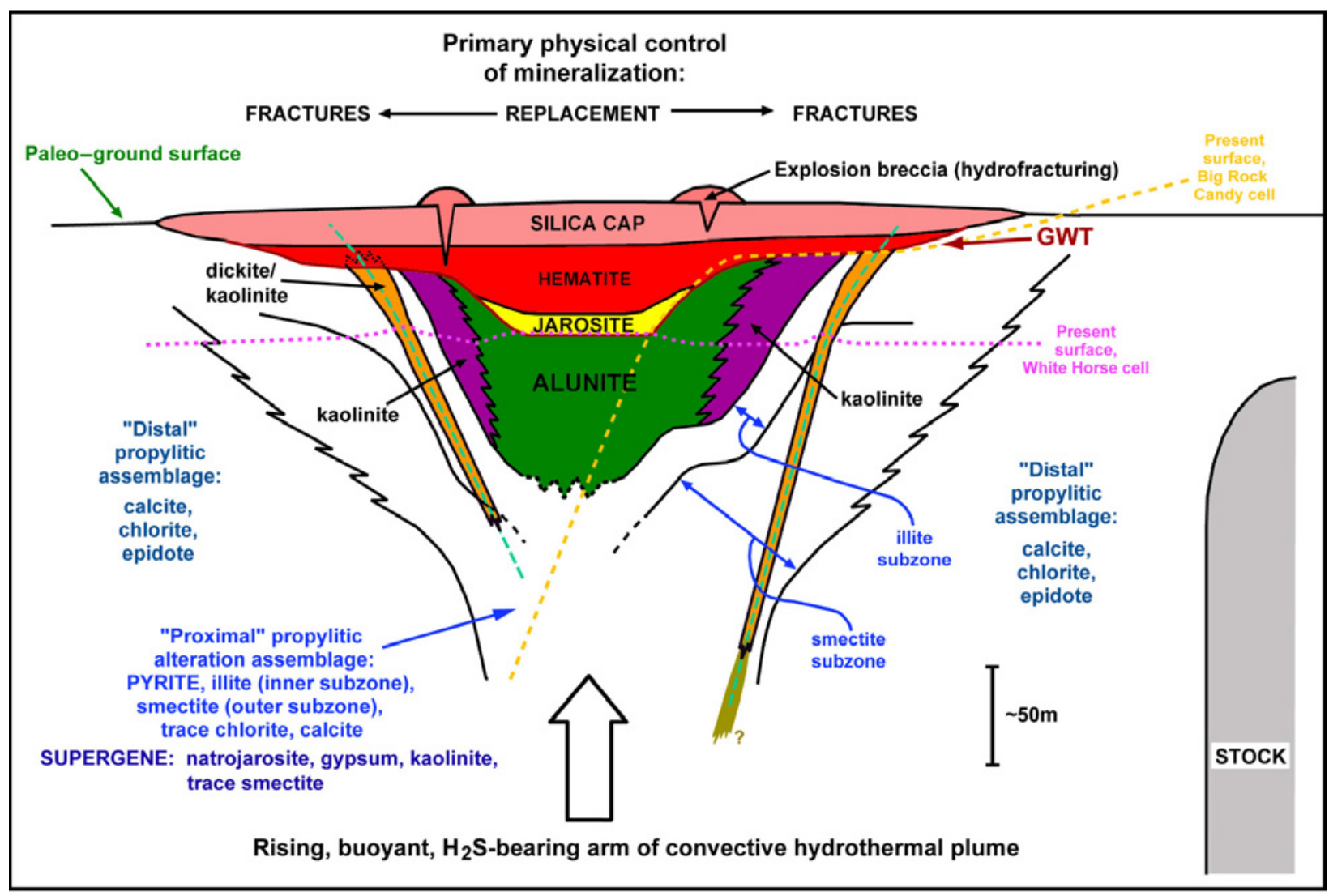

EXPLANATION:

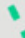
1 silica-bearing fracture zones

pyrophyllite in fractures or veinlets (may include natroalunite at higher levels) GWT paleo-ground-water table
Figure 55. Genetic model for replacement alunite deposits, Antelope Range, Marysvale volcanic field, Utah. Approximate current levels of erosion are indicated for the White Horse (pink dotted line) and Big Rock Candy Mountain (yellow-orange dashed line) hydrothermal cells. Coarsegrained jarosite formed by hypogene processes is shown in bright yellow. Fine-grained natrojarosite formed by modern supergene oxidation of pyrite is present only where the underlying feeder zones of the systems have been exposed by erosion. 
pulverized, and split with diluted heavy liquids and magnetic separators to isolate the jarosite. Figure $\mathbf{5 7}$ shows that the SWIR spectral features of the library reference spectrum of natrojarosite (GDS24, from Clark, Swayze, Wise, and others, 2003) closely resemble those of purified natrojarosite from Big Rock Candy Mountain. For comparison, the AVIRIS spectrum in figure 57 represents an areal mixture of natrojarosite, illite, montmorillonite (smectite), and gypsum from which jarosite composition cannot be discerned.

Not all of the jarosite that formed by supergene processes in the Antelope Range is rich in sodium. Exposures of jarositic float were discovered near the top of Big Rock Candy Mountain by analysis of the low-altitude AVIRIS data (fig. 52). This jarosite was found to be rich in potassium and to have a mud-like texture and $\delta^{34} \mathrm{~S}$ and $\delta^{18} \mathrm{O}_{\mathrm{SO}_{4}}$ values that suggest a supergene origin. This jarosite is, therefore, thought to be derived from the oxidation of pyrite from the feeder zone of a slightly older or "nested" hydrothermal cell $\approx 0.75 \mathrm{~km}$ southwest of Big Rock Candy Mountain that is exposed at slightly higher elevations than the feeder zone on the east face of the mountain above the Sevier River (Cunningham and others, 2005).

The hypogene and supergene jarosites most likely have different acid-producing potentials and, thus, different implications regarding environmental impact. Leach studies are needed to determine the relative APPs of jarosites of varying compositions (substitutions of $\mathrm{Na}, \mathrm{K}$, and $\mathrm{H}_{3} \mathrm{O}$ ) formed under different geochemical conditions. Although rocks associated with either hypogene or supergene jarosite will have some APP, it is likely that the exposures of jarosite formed by supergene processes from pyrite-bearing rocks will have higher APP and thus will represent a greater potential for heavy-metals release than the hypogene jarosite that occurs with alunite and other argillic alteration minerals, but not with pyrite, at higher levels in the hydrothermal systems (fig. 55). Most of the hypogene jarosite

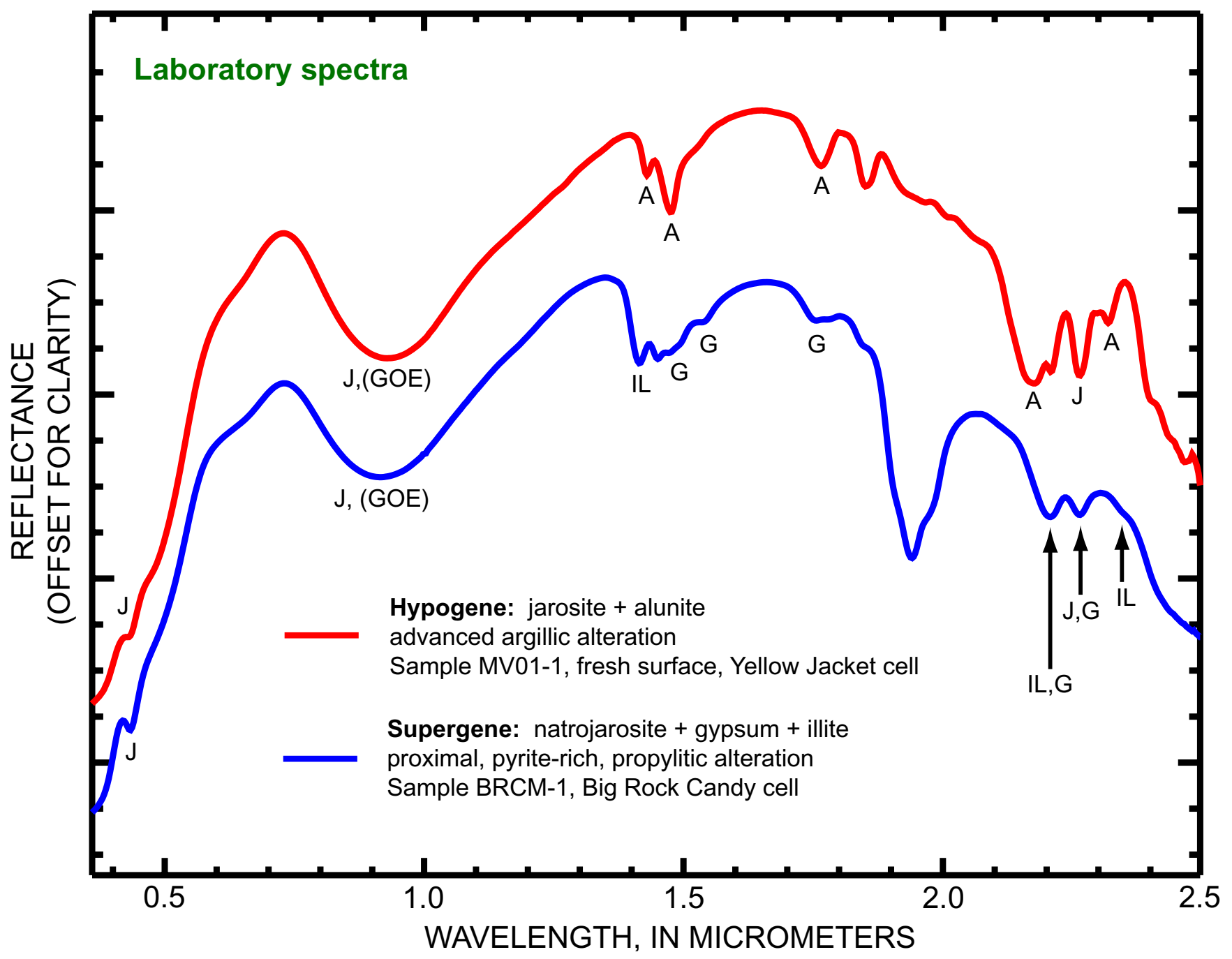

Figure 56. Laboratory spectra of jarosite-bearing rocks formed by hypogene and supergene processes. XRD results and sampling locations for these rocks are given in appendix table $\mathbf{A} 3$. Absorption features caused by specific minerals are indicated. $\mathrm{J}=$ jarosite. $\mathrm{A}=$ alunite. $\mathrm{IL}$ = illite. $\mathrm{G}$ = gypsum. $(\mathrm{GOE})=$ possible goethite. 
associated with the replacement alunite deposits has been eroded away, although it is still present and well exposed in the northern and southwestern parts of the Yellow Jacket cell. It is unknown whether such jarosite is exposed in the $\mathrm{Al}$ Kee Mee and White Hills cells, as these cells do not lie within the coverage of the high-altitude AVIRIS data. The pyrite-bearing rocks of the propylitically altered feeder zones are exposed in the Big Rock Candy Mountain, Big Star, and White Horse hydrothermal cells (figs. 47, 50, and 52). These pyrite-bearing rocks are especially evident along Marysvale Canyon at Big Rock Candy Mountain where the Sevier River has down-cut into the cores of several of the hydrothermal cells (fig. 58). The current levels of erosion at the White Horse and Big Rock Candy cells are indicated in figure 55. Thin, yellowish-orange crusts containing copiapite, alunogen, and epsomite form within drainage channels on the northern and eastern flanks of the mountain after rain events, and the $\mathrm{pH}$ of the surface runoff from the face of the mountain measured 2.6 (appendix table A3, sample
M979b, and Cunningham and others, 2005). Pyrite- and jarosite-bearing sediments are actively being deposited in drainages running northward, northeastward, and eastward from the mountain (fig. 59), and it can be assumed that some natural acidic runoff is reaching the north-flowing Sevier River. ICP-MS (inductively coupled plasma-mass spectrometry) analyses of the natrojarosite from Big Rock Candy Mountain indicate the presence of appreciable amounts of molybdenum (325 ppm), zinc (115 ppm), and copper (110 ppm); surface runoff from Big Rock Candy Mountain was found to contain elevated levels of $\mathrm{Ca}, \mathrm{Mg}, \mathrm{Si}, \mathrm{Al}, \mathrm{Fe}, \mathrm{Mn}, \mathrm{Cl}$, and $\mathrm{SO}_{4}$ (Cunningham and others, 2005). In general, however, there is a relative paucity of metals in the replacement alunite deposits in the Antelope Range when compared to other ore deposits in Utah. It has been suggested that metals either were never abundant in these hydrothermal systems or may have been precipitated at depth from the rising fluids reacting with

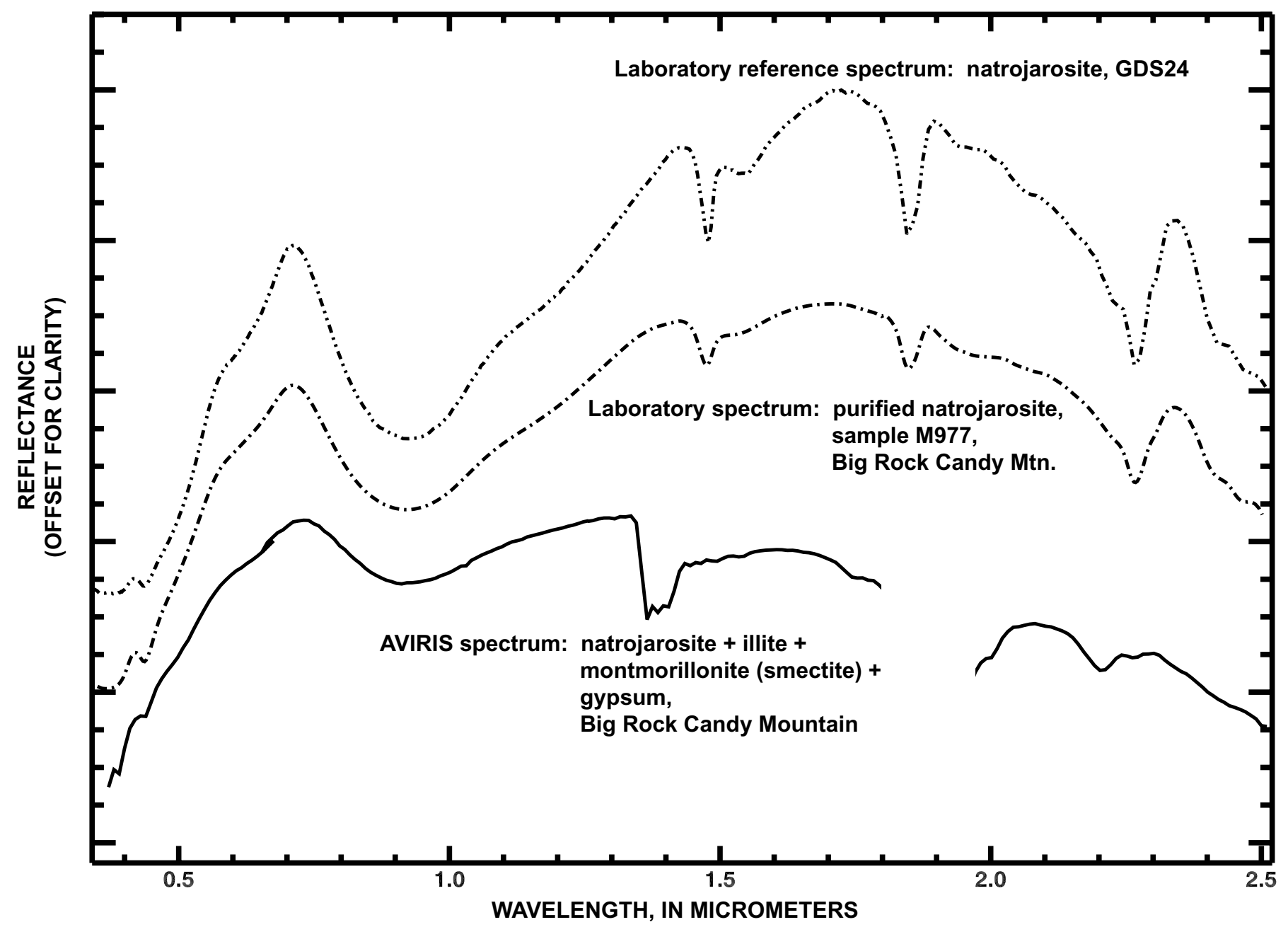

Figure 57. Spectra of natrojarosite from Big Rock Candy Mountain and the reference library. Because the jarosite is closely associated with other minerals, jarosite composition is not discernible in the AVIRIS spectrum. After the jarosite is separated from the other minerals, however, the diagnostic SWIR spectral features of natrojarosite near $2.27 \mu \mathrm{m}$ are visible. The complete laboratory characterization of the jarosite from Big Rock Candy Mountain is reported in Cunningham and others (2005). 


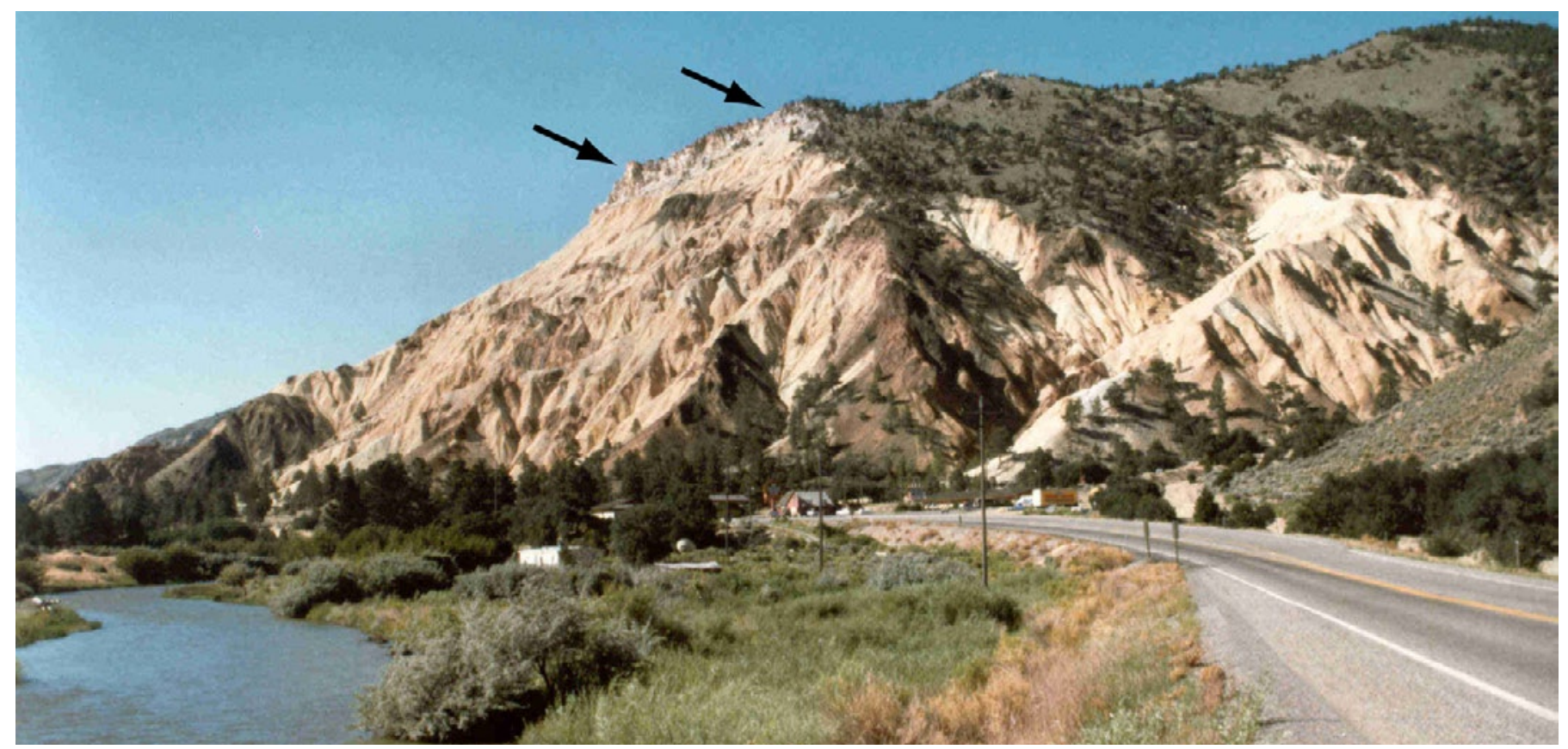

Figure 58. View of Big Rock Candy Mountain looking south along Marysvale Canyon. The Sevier River is at lower left. The yellowish color of the rocks on the exposed flanks of the mountain is caused by thin coatings of natrojarosite formed by supergene weathering of pyrite-bearing rocks from the propylitically altered feeder zone of an acid-sulfate hydrothermal cell. The cell was active at $\approx 21$ Ma. Residual alunite - which was formed at and just below the paleo-ground-water table of the ancient hot-springs system-is visible at the very top of the mountain as subhorizontal, white cliffs (arrows). Photograph by Charles G. Cunningham.

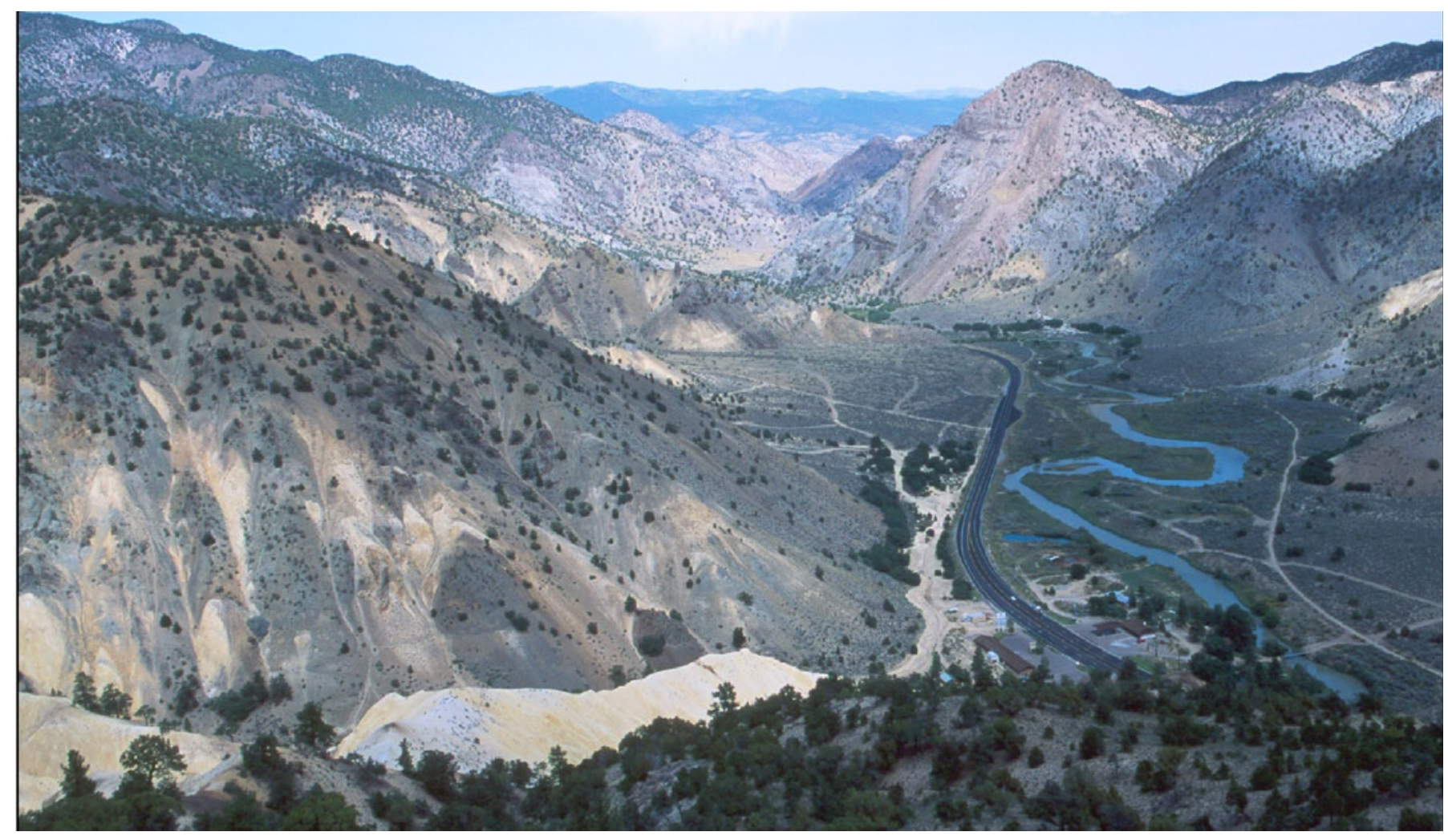

Figure 59. View of Marysvale Canyon looking north from the top of Big Rock Candy Mountain. The meandering, north-flowing Sevier River is at right. Yellowish-white, natrojarosite-bearing alluvial sediments shed northward from the face of the mountain can be seen in stream channel on west side of Route 89. Altered (yellowish-white) rocks of the Big Star hydrothermal cell are just visible at the extreme right of the photograph east of the river. 


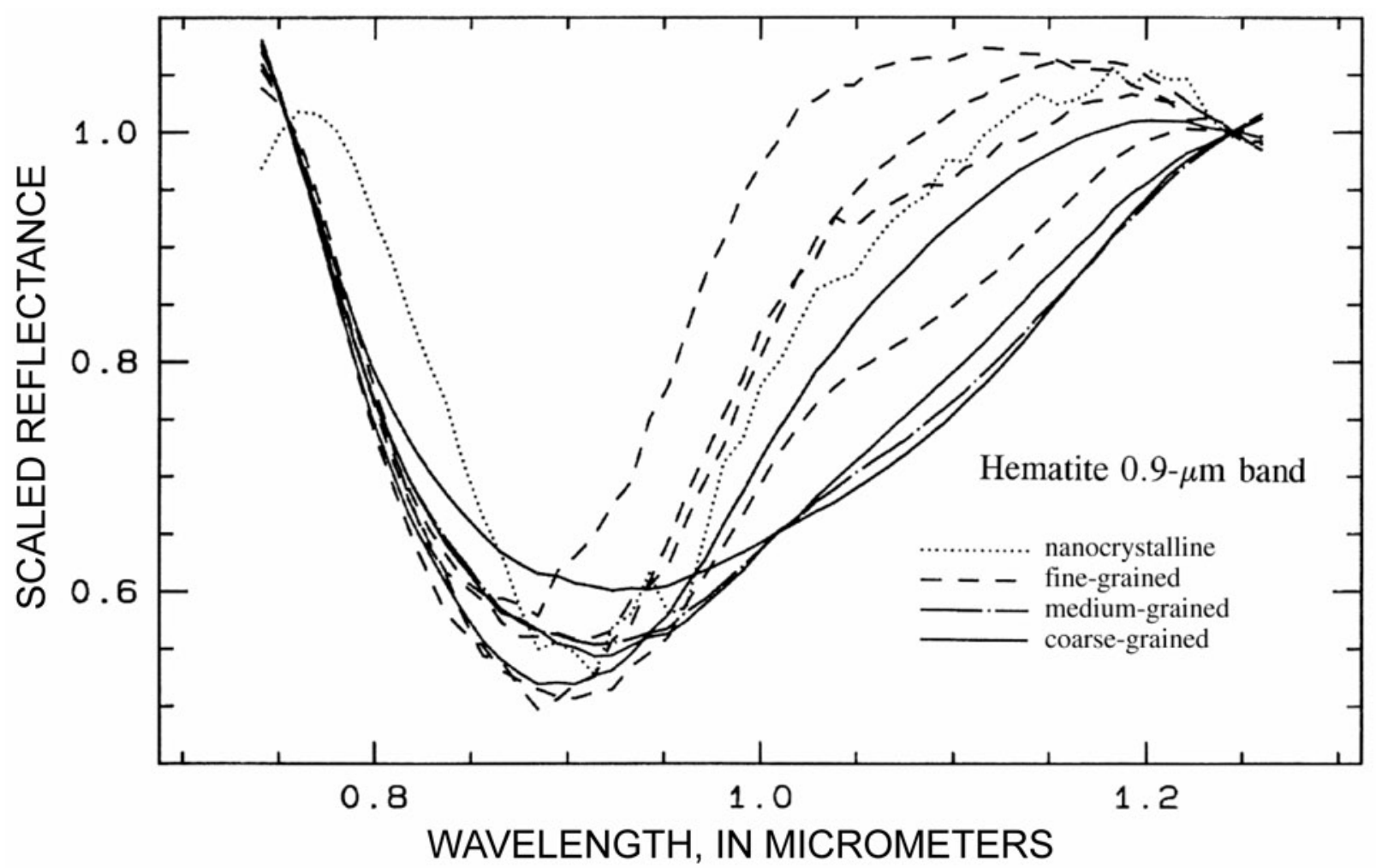

Figure 60. Hematite grain-size series. All spectra are in continuum-removed format. Larger grain sizes show broadening of the crystal field absorption at $0.9 \mu \mathrm{m}$ caused by increased saturation, as well as the shifting of the apparent reflectance minima to longer wavelengths. Modified from Clark (1999).

Mesozoic sedimentary rocks in the subsurface (Cunningham and others, 1984).

\section{Spectral Variations in Goethite-Bearing Rocks Observed by AVIRIS}

The maps of iron-bearing minerals generated for this report from the AVIRIS data show areas identified as goethite of varying grain sizes associated with altered rocks, soils, and tailings material. The spectral variations responsible for this differentiation of the goethite-bearing material are thought to be related to mineral composition and abundance as well as grain size, as will be demonstrated by research currently under way at the USGS (Rockwell, 2004). Previous studies have shown that the distance (or path length) a photon may travel within a mineral grain increases with effective grain size, as larger grains offer increased volume-to-surface ratios and reduced chances for surface reflection (Clark, 1999). Therefore, in the VIS and NIR spectral regions, as grain size increases, path length and absorption increase while reflectance level decreases. Figure 60 shows spectra of a grain-size series generated from powdered and sieved hematite and illustrates how larger grain sizes exhibit increased saturation of the crystal field absorption at $0.9 \mu \mathrm{m}$, indicated by the broadening of the feature and shifting of the apparent reflectance minima to (slightly) longer wavelengths. The spectra shown in figure 60 were added to the spectral library used by the Tetracorder expert system and were labeled as a hematite grain-size series; laboratory-derived spectra of goethite exhibiting similar spectral variations were added to represent a goethite grain-size series (Clark, Swayze, Livo, and others, 2003). Analysis of imaging spectrometer data using the expert system thus subdivides hematite- and goethite-bearing pixels into grain-size groups on the basis of degree of curve fit to the grain-size series. In areas underlain by altered rocks associated with supergene oxidation of pyrite-bearing rocks, such as those of the Big Rock Candy and Big Star hydrothermal cells adjacent to the Sevier River (fig. 59), the AVIRIS maps of iron-bearing minerals in those cells (figs. 50 and 52) show an outward gradation from outcrops with fine-grained coatings of jarosite, to areal mixtures of jarosite and goethite, to coarse-grained goethite with trace jarosite, to coarse-grained goethite, medium-grained goethite, fine-grained goethite, and finally to thin coatings of goethite. The subradial pattern of these mineral zones represents a weathering transition from outcrop to colluvial and (or) alluvial float in which the size of the clastic rock fragments bearing ferric iron decreases outward, jarosite gives way to goethite, and the abundance of ferric iron decreases relative to soil components and vegetation. 
Figure 61 shows single-pixel high-altitude AVIRIS spectra sampled from altered rocks of the Big Star cell across the Sevier River from Big Rock Candy Mountain (figs. 47 and 59). The colors of the spectra in figure $\mathbf{6 1}$ are similar to those of the goethite mineral classes on the mineral maps that they represent (figs. $\mathbf{5 0}$ and 52). Like the spectra in the hematite grain-size series shown in figure $\mathbf{6 0}$, the goethite spectra in figure $\mathbf{6 1}$ show a general broadening and shift of the absorption position to longer wavelengths with increasing grain size. The spectrum identified as coarse-grained goethite with trace jarosite (shown in magenta) shows a small shift of the absorption minimum back toward shorter wavelengths and a small feature at $0.43 \mu \mathrm{m}$, both indicative of the trace content of jarosite. However, it is evident that the overall shape of the $0.9-\mu \mathrm{m}$ absorption feature is quite similar to that of the coarsegrained goethite spectrum shown in dark green (spectrum no. 4). A positive spectral feature near $1.1 \mu \mathrm{m}$ in the spectrum of fine-grained goethite is a residual artifact caused by atmospheric water vapor.

On the AVIRIS mineral maps, the number of pixels identified as thin coatings of goethite is far greater than the number of pixels identified as coarse- or medium-grained goethite. The areas identified as thin coatings of goethite correspond generally to distal alluvial surfaces containing goethite-bearing rock fragments in low abundance relative to soil components with low iron content and sparse vegetation. Areas identified as coarser-grained goethite correspond to proximal alluvial and outcrop surfaces bearing abundant coarser-grained goethite with little to no soil component. Rock fragments that have been spectrally characterized in the laboratory as coarse-grained goethite have been found in areas identified with AVIRIS as coarse-grained goethite and as thin coatings of goethite. For this reason, goethite abundance also appears to influence the observed spectral variations in goethite-bearing areas. In future studies, both abundance and grain-size variations should be considered when interpreting the iron-mineral identification results generated by the expert system.

On pyrite-bearing waste-rock piles at mine sites, the zonal pattern of jarosite and goethite described here generally holds true, as both jarosite and coarser-grained goethite tend to occur closer to the center of the piles where pyrite oxidation and acid generation are still active (for example, figs. 13, 15, and 17). Where tailings material is present, pixels identified as coarser-grained goethite on the mineral maps may indicate areas in which goethite may be more abundant, whereas thin coatings of goethite most likely indicate areas in which tailings material is present only as a thin surface veneer, as is the case in the most distal parts of the Mercur Canyon outwash deposits in Rush Valley (figs. 31 and 33). As goethite and hematite are very common on the Earth's surface, an understanding of the spectral variations resulting from differences in abundance and (or) grain size will enhance and facilitate the discrimination and characterization of outcrop and alluvial surfaces, providing valuable information for geologic, geomorphologic, mineral exploration, and environmental assessment studies.

\section{Acid-Sulfate Alteration on Alunite Ridge and Deer Trail M ountain}

The acid-sulfate hydrothermal alteration exposed on Alunite Ridge and Deer Trail Mountain in the eastern Tushar Mountains was formed much later (at $\approx 14 \mathrm{Ma}$ ) than the replacement alunite in the Antelope Range (23-21 Ma) and under contrasting geochemical and geologic conditions. Geologic evidence including radial fracture patterns, concentric ring fractures, and steeply tilted wall rocks points to the existence of two unexposed intrusions of similar age underlying Alunite Ridge and the summit of Deer Trail Mountain (Cunningham and others, 1984). The most intense acid-sulfate alteration is centered on these two areas, which are nearly devoid of base and precious metals, at least near the surface. Surrounding these alteration centers are zones of fractured, less altered rock containing the clay minerals kaolinite and dickite that, in turn, grade outward to illite and, finally, to propylitically altered host rock of the Bullion Canyon Volcanics. Below the acid-sulfate alteration, these outer zones of less altered rock are more likely to contain deposits of precious and base metals. Approximately $900 \mathrm{~m}$ vertically below and $\approx 2 \mathrm{~km}$ east of the argillic and weak advanced argillic alteration near the summit of Deer Trail Mountain, both the Old Deer Trail mine and the (new) Deer Trail mine have exploited ore bodies found within this outer alteration zone.

On Alunite Ridge, veins of coarsely crystalline alunite up to $20 \mathrm{~m}$ wide are present within larger envelopes of alunitized and argillized host volcanic rocks. Clays are not abundant within the veins of pink alunite exposed in the local mines. The abundance of natroalunite and clays in the altered wall rock appears to increase with vertical distance above the Mineral Products mine, and these minerals were mapped pervasively on the northern part of Alunite Ridge in the area surrounding the Christmas mine and on the south face of Mount Brigham by using the high-altitude AVIRIS data (fig. 49). However, the wall-rock alteration is partly masked by abundant forest vegetation that occurs on the ridge below the treeline located $\approx 60 \mathrm{~m}$ below the Christmas mine. The alteration center on Deer Trail Mountain is characterized mainly by replacement kaolinite with minor dickite and sericite at the summit. Primarily colluvial dickite, kaolinite, and minor alunite are best exposed $\approx 1 \mathrm{~km}$ to the north-northeast and south-southwest of the summit on the mountain flanks, suggesting that a north-northeast-striking fracture trend exists that may have significance for base and precious metal exploration lower down in the system. Most of the vein alunite deposited above the present-day summit of Deer Trail Mountain has been eroded away, and the kaolinite and dickite present near the summit represent the roots of the hydrothermal system. Substantial amounts of alunite and clay minerals have been shed eastward from these altered areas down into the Sevier River valley, not only in the Close In landslide deposit along the mountain front but also within incised terraces deposited by the ancestral Cottonwood Creek along the west bank of the Sevier River (figs. 4 and 51).

Jarosite (fig. 48, $\approx 260 \mathrm{~m}$ south-southeast of Christmas mine) was found to occur with alunite along fractures cutting illite in a hand sample and along fractures cutting alunite at the Mineral Products mine. Jarosite was not mapped with the AVIRIS data at the Mineral Products mine because the jarosite 

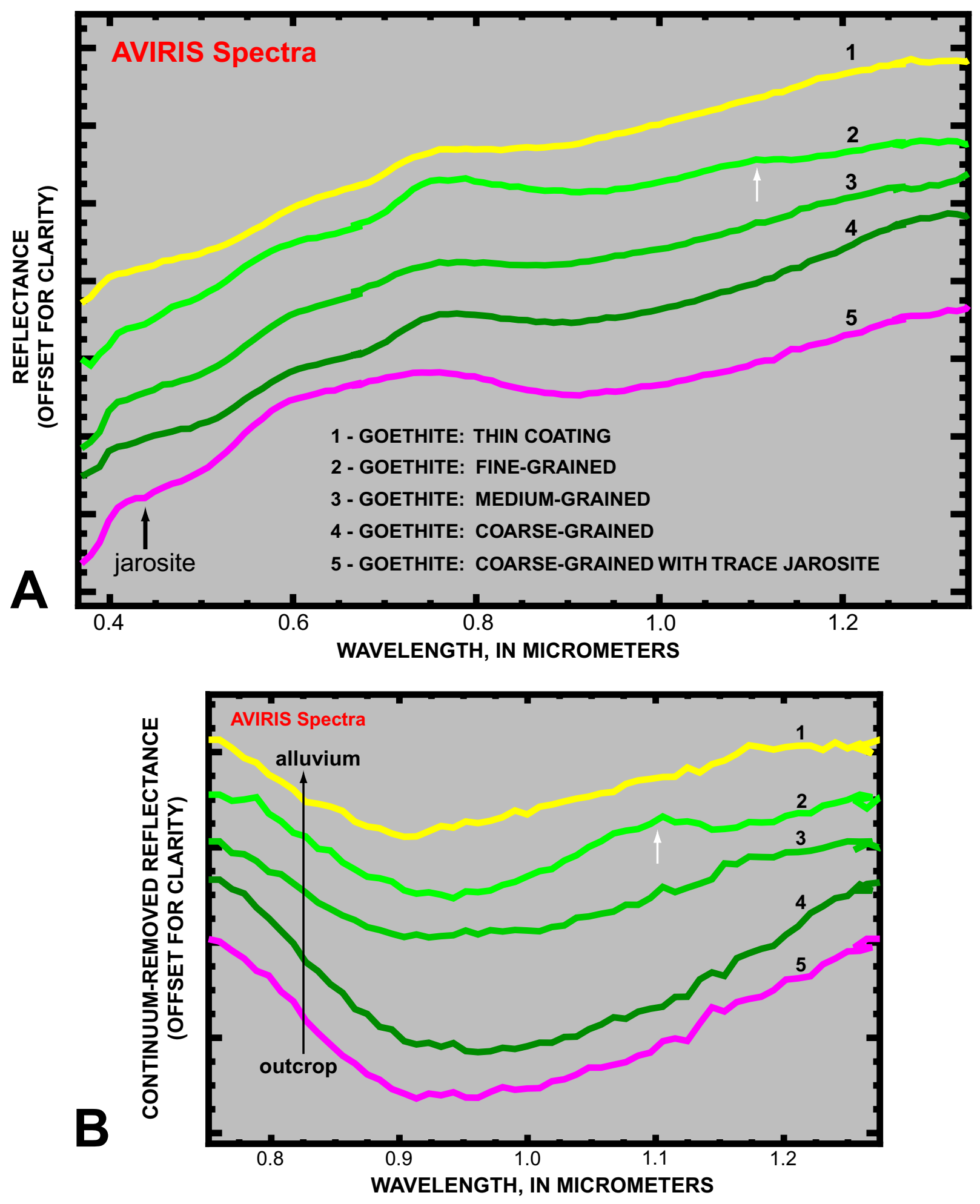

Figure 61. Goethite grain-size series. Plots show single-pixel reflectance spectra sampled from high-altitude AVIRIS data at the southwestern edge of the Big Star hydrothermal cell adjacent to the Sevier River. (A) AVIRIS reflectance spectra. (B) Same spectra in continuum-removed format in vicinity of crystal field absorption caused by ferric iron near $1.00 \mu \mathrm{m}$. The white arrow indicates a residual artifact most likely caused by atmospheric water vapor. 
occurs along fractures that are best exposed on the near-vertical walls of the open stopes of the mine and are, therefore, not well exposed for mapping with high-altitude AVIRIS data. The jarosite on Alunite Ridge was probably derived from the supergene oxidation of pyrite in host rocks and aplite dikes near the uppermost parts of the alunite-bearing veins. Exposures of "coarse-grained" jarosite were mapped with the AVIRIS data in four main locations in the east-central Tushar Mountains and Sevier River valley (figs. 48 and 50): (1) on Alunite Ridge, (2) in bedrock and colluvium on the flanks of Deer Trail Mountain to the northeast and southwest of the summit, (3) in colluvium underneath cliffs located east of Hennesy Point $\approx 2.5 \mathrm{~km}$ north-northeast of the summit of Deer Trail Mountain, and (4) locally on pediment surfaces in the Sevier River valley immediately west of the river (fig. 4). The jarosite occurrence on Alunite Ridge has been verified by field observations. In all four places, the jarosite is associated with argillized rocks bearing alunite, kaolinite, dickite, and (or) illite/muscovite. Hypogene jarosite of the type found in the replacement alunite deposits in the Antelope Range area is not expected to occur on Alunite Ridge and Deer Trail Mountain and has not been identified there. Some acidic runoff derived from the oxidation of pyrite or other sulfide and sulfate minerals may be generated in the altered areas on Alunite Ridge and Deer Trail Mountain and, in the Sevier River valley, in the alluvial and colluvial deposits of aluniteand (or) jarosite-bearing rocks that are derived from these altered areas. Immediately west of the Sevier River, pediments with alunite-, jarosite-, and kaolinite-bearing surfaces are currently being incised along east-flowing drainages.

\section{Rocks with Acid-Neutralizing Potential (ANP)}

The detection of acid-buffering mineral assemblages containing calcite, chlorite, and (or) epidote that are associated with either sedimentary rocks or propylitic alteration within and adjacent to intrusive rocks is important in assessing local acid-neutralizing potential. Some other scattered pixels of calcite mapped with the AVIRIS data represent caliche in alluvial soils, such as in Quaternary alluvium west of Joseph at the north end of figure 51, within the Bullion Canyon Volcanics north of the Yellow Jacket cell, and within the Joe Lott Tuff Member of the Mount Belknap Volcanics and alluvium to the northeast of the Yellow Jacket cell. Pyrite-poor, propylitically altered intrusive rocks located east of the Sevier River in the vicinity of Big Rock Candy Mountain are characterized by abundant epidote, calcite, and chlorite (fig. 51 and Rockwell and others, 2000). These minerals have moderate to high acidneutralizing potential and, thus, may serve to buffer some of the acidic solutions generated by the pyrite-rich feeder zone of the Big Rock Candy cell. Relatively small exposures of calcite associated with Paleozoic and Mesozoic limestones were mapped with the AVIRIS data in the eastern Tushar Mountains (fig. 51). These limestone outcrops have shed calcite-bearing alluvial sediments eastward into the Sevier River valley immediately north and 4-5 km southeast of the (new) Deer Trail mine. These carbonate-bearing rocks and sediments may serve to buffer acidic solutions generated by the sulfide-bearing rocks related to carbonate-hosted ore deposits beneath Deer Trail Mountain and alluvial deposits of sulfate-bearing rock in the Sevier River valley.

\section{Conclusions}

Interpretation of watershed- or regional-scale maps of selected surface minerals derived from analysis of imaging spectroscopy data such as AVIRIS can be an effective means of (1) evaluating environmental factors associated with hydrothermally altered rocks and mine waste and (2) focusing subsequent site-evaluation and remediation efforts. An understanding of local geology is essential for accurately interpreting geo-environmental impact from the mineral maps. The mineral maps may be useful in directing the collection of ground samples that can be tested for possible elevated metal levels. In assessing the environmental condition of mining districts, the USEPA is mainly interested in geochemical site screening in terms of mapping the sources and the transport and fate of toxic trace metals that can adversely affect human health. So far, remote-sensing methods can reliably target only sources of acid generation and buffering, although laboratory characterization (for example, XRF [X-ray fluorescence] and ICP-MS [inductively coupled plasma-mass spectrometry]) of field samples can establish direct and indirect mineralogical relationships between remotely sensed targets and trace metals (for example, the association of goethite, kaolinite, and muscovite in the mill tailings of the Mercur and Manning Canyon areas that is directly associated with elevated levels of trace metals). It should be noted that this study did not attempt to identify any radiological hazards associated with waste-rock piles in areas from which uranium was extracted.

Large exposures of unmined, hydrothermally altered rock exist throughout the East Tintic Mountains, Tushar Mountains, and Antelope Range, which constitute the three areas studied for this report. These rocks are likely to contain sulfide and (or) sulfate minerals that, as they are subaerially oxidized, produce sulfuric acid, resulting in increased acidity of local surface water. Such naturally occurring acidic water should be taken into account when examining the district in a watershed context.

Mine tailings and waste rock containing sulfide minerals and heavy metals were spectrally identified in the East Tintic Mountains and Oquirrh Mountains. These materials are point sources for acid generation and metal contamination. Because of the dry climate, down-gradient alluvial transport of these materials is quite limited. However, eolian transport of these materials has most likely occurred at some of the sites studied. Locally abundant carbonate rocks in the region provide a natural acid-neutralizing potential (ANP) that inhibits metal movement by surface or ground water. Only surficial minerals were mapped with the AVIRIS data in this study, so the presence 
or extent of metal contamination of ground water, surface water, or subsurface soils at the sites studied is unknown. Plumes of acidic solutions and dissolved heavy metals derived from waste-rock piles have previously been documented in the Oquirrh Mountains (U.S. Environmental Protection Agency, 2002c).

Although many waste-rock piles in the Tintic mining district contain oxidizing sulfide minerals and are, thus, important potential point sources of acid generation and heavy-metals release, little spectral evidence was found for downstream or downwind movement of these minerals. In most cases, acidproducing rocks are confined to mine sites, largely because of low amounts of annual precipitation. Owing to the proximity of the Chief No. 1 and Centennial/Eureka mines to the town of Eureka, further study of their waste-rock piles and local hydrology is warranted. The tailings and waste rock near the Burgin mine in the East Tintic subdistrict are the largest spectrally identified exposures of jarositic rocks in the Tintic mining district, and the ground and surface water of this area should also be sampled. Few exposures of carbonate-bearing rock exist downstream from most mine sites; therefore, in general, relatively little natural ANP exists that could buffer acidic solutions emanating from the waste-rock piles.

In the Oquirrh Mountains, interpretation of AVIRISderived mineral maps revealed four sites with mineral concentrations that might indicate the presence of elevated metal levels associated with hydrothermally altered rocks and mill tailings: Mercur Canyon outwash, Manning Canyon, the Bauer Mill site, and the International Smelter and Refining site. Interpretation of the AVIRIS-derived mineraldistribution patterns, along with field and laboratory studies, indicates that elevated metal levels, specifically arsenic, are present at the Mercur Canyon outwash and Manning canyon sites. Pyrite-bearing mill waste is abundant in the vicinity of the Bauer Mill site in the Rush Valley near Stockton. It is likely that some of this waste is being transported from the mill site by prevailing southerly winds. Near the International Smelter and Refining site, small exposures of jarosite possibly associated with pyrite-bearing mill tailings were also identified through the use of the AVIRIS data, but these exposures have not been field verified. The high-altitude AVIRIS maps of Manning Canyon show deposits of goethite-bearing alluvial sediments, possibly associated with elevated arsenic levels, along drainages and in cultivated fields down-gradient from the mill site and the thick deposits of tailings there.

In the Antelope Range area of the Marysvale volcanic field in Sevier and Piute Counties, pyrite-bearing rocks having high acid-producing potential (APP) were mapped by using the AVIRIS data only in the propylitically altered feeder zones of the Big Rock Candy cell, at the southwestern edge of the Big Star cell (both next to the Sevier River), and at the White Horse cell. Significant amounts of sediments containing jarosite, goethite, and possible pyrite are being shed from the exposed eastern and northern slopes of Big Rock Candy Mountain in Marysvale Canyon. Little evidence was found for downstream movement of jarositic sediments from the other hydrothermal cells in the Antelope Range. Hypogene jarosite co-occurring with alunite is found in altered rocks stratigraphically above the pyrite-bearing feeder zones throughout the Antelope Range. These rocks most likely have somewhat lower APP than the pyrite-bearing rocks. Although other studies have identified metals such as $\mathrm{Zn}, \mathrm{Cu}$, and Mo in pyrite-bearing rocks at Big Rock Candy Mountain, metals available for transport are not abundant in and around the replacement alunite deposits of the Antelope Range. Exposures of jarosite derived from pyrite oxidation are also found in the eastern Tushar Mountains in the vicinities of Alunite Ridge and Deer Trail Mountain, as are large exposures of alunite. In general, the hydrothermal systems active in the Miocene (23-21 Ma) in the Antelope Range, though relatively poor in metals, produced sulfidebearing rocks overlain by sulfate-bearing rocks. Little natural ANP exists around these altered rocks other than propylitically altered igneous rocks containing calcite, chlorite, and epidote. In contrast, the younger (14 Ma) alteration systems on Mount Brigham, Alunite Ridge, and Deer Trail Mountain are rich in metals and consist of one or more concentric zones of sulfide minerals around barren cores of highly altered, alunite-bearing rock. The metallic ore deposits lower in the systems are hosted by carbonatebearing sedimentary formations having abundant natural ANP, whereas the alunite-bearing veins occurring higher in the systems on Alunite Ridge and Deer Trail Mountain are hosted by volcanic rocks that have been locally sulfidized and argillized and have little to no ANP. To quantify the potential local environmental effects related to acid drainage derived from these altered rocks, further chemical analyses should be performed on the ground and surface water in these areas. No significant occurrences of mine waste or mill tailings that contain oxidizing sulfide minerals were positively identified through the use of the AVIRIS data in the Tushar Mountains/Marysvale region, although goethite was detected in what could be historical mill tailings located near the Old Deer Trail mine.

\section{Acknowledgments}

We thank several U.S. Geological Survey (USGS), U.S. Environmental Protection Agency (USEPA), National Aeronautics and Space Administration (NASA), and U.S. Bureau of Reclamation (USBOR) personnel for their assistance on this project: Robert O. Green and the rest of the AVIRIS team at NASA Jet Propulsion Laboratory (JPL) for providing the high-quality remote-sensing data that were the centerpiece of the Utah AML project; Roger N. Clark, for his role in starting the Utah Imaging Spectroscopy Project, his advice on calibration techniques, collection of calibration spectra, and field assistance; Stephen J. Sutley, who helped perform the X-ray diffraction analyses; Charles G. Cunningham, for background geologic information, 
the photograph of Big Rock Candy Mountain, purifying the natrojarosite from Big Rock Candy Mountain, field assistance, and other valuable insights; Tony Selle, Ken Wangerud, and Luke Chavez (USEPA) for initiating and funding the Utah Imaging Spectroscopy Project; K. Eric Livo for the planning of the high-altitude AVIRIS flightlines, collection of calibration spectra, and field assistance; Ron Pearson (USBOR) for field XRF operation and field assistance; Raymond F. Kokaly for collection of calibration spectra; and J. Sam Vance (USEPA) for his role in starting the Utah Imaging Spectroscopy Project, providing contacts with State and Federal agencies and mining companies, and field assistance. We also thank Daniel H. Knepper, Jr., Trude V.V. King, and George A. Desborough of the USGS for their helpful reviews of this manuscript. Mary Eberle also deserves special thanks for her thorough and professional editing of the manuscript.

\section{References Cited}

Atkinson, W.W., Jr., ed., 1976, Geology of the Oquirrh Mountains and regional setting of the Bingham mining district, Utah: Salt Lake City, Utah, Utah Geological Association Publication 6, 36 p.

Beaty, D.W., Cunningham, C.G., Rye, R.O., Steven, T.A., and Gonzalez-Urien, E., 1986, Geology and geochemistry of the Deer Trail Pb-Zn-Ag-Au-Cu manto deposits, Marysvale district, west-central Utah: Economic Geology, v. 81, p. 1932-1952.

Bigham, J.M., Schwertmann, U., and Carlson, L., 1992, Mineralogy of precipitates formed by the biogeochemical oxidation of Fe(II) in mine drainage, in Skinner, H.C.W., and Fitzpatrick, R.W., eds., Biomineralization processes of iron and manganese-Modern and ancient environments: Catena Supplement 21, p. 219-232.

Boardman, J.W., 1999, Precision geocoding of low-altitude AVIRIS data-Lessons learned in 1998, in Green, R.O., ed., Summaries of the Eighth Annual JPL Airborne Earth Science Workshop, NASA JPL AVIRIS Workshop, Pasadena, California, U.S.A., February 8-11: Pasadena, California, JPL Publication 99-17, p. 63-68; available at ftp://popo.jpl. nasa.gov/pub/docs/workshops/99_docs/7.pdf (last accessed 8 September 2004).

Bowell, R.J., 1994, Sorption of arsenic by iron oxides and oxyhydroxides in soils: Applied Geochemistry, v. 9, p. 279-286.

Callaghan, E., 1973, Mineral resource potential of Piute County, Utah, and adjoining area: Utah Geological and Mineralogical Survey Bulletin 102, 135 p.
Clark, R.N., 1999, Spectroscopy of rocks and minerals, and principles of spectroscopy, in Rencz, A.N., ed., Remote sensing for the earth sciences, in Ryerson, R.A., ed., Manual of remote sensing, Volume 3: New York, John Wiley, p. 358; available at URL http://speclab.cr.usgs.gov/PAPERS. refl-mrs/refl4.html (last accessed 8 September 2004).

Clark, R.N., Livo, K.E., and Kokaly, R.F., 1998, Geometric correction of AVIRIS imagery using on-board navigation and engineering data, in Green, R.O., ed., Summaries of the Seventh Annual JPL Airborne Earth Science Workshop: Pasadena, California, JPL Publication 99-21, p. 57-65.

Clark, R.N., Swayze, G.A., Livo, K.E., Kokaly, R.F., Sutley, S.J., Dalton, J.B., McDougal, R.R., and Gent, C.A., 2003, Imaging spectroscopy - Earth and planetary remote sensing with the USGS Tetracorder and expert systems: Journal of Geophysical Research, v. 108, no. E12, 5131, doi: 10.1029/2002JE001847.

Clark, R.N., Swayze, G.A., Wise, R., Livo, K.E., Hoefen, T.M., Kokaly, R.F., and Sutley, S.J., 2003, USGS Digital Spectral Library splib05a: U.S. Geological Survey OpenFile Report 03-395; available at URL http://pubs.usgs. gov/of/2003/ofr-03-395/ofr-03-395.html (last accessed 8 September 2004).

Cook, D.R., ed., 1957, Geology of the East Tintic Mountains and ore deposits of the Tintic mining districts: Salt Lake City, Utah Geological Society, Guidebook to the Geology of Utah, no. 12, 183 p.

Cox, D.P., and Singer, D.A., eds., 1986, Mineral deposit models: U.S. Geological Survey Bulletin 1693, Model 19a; available at URL http:/greenwood.cr.usgs.gov/pub/bulletins/ b1693/ (last accessed 8 September 2004).

Crowley, J.K., Williams, D.E., Hammarstrom, J.M., Piatak, N., Chou, I-Ming, and Mars, J.C., 2003, Spectral reflectance properties (0.4-2.5 $\mu \mathrm{m})$ of secondary Fe-oxide, Fe-hydroxide, and Fe-sulphate-hydrate minerals associated with sulphide-bearing mine wastes: Geochemistry: Exploration, Environment, Analysis, v. 3, p. 219-228.

Cunningham, C.G., Rasmussen, J.D., Steven, T.A., Rye, R.O., Rowley, P.D., Romberger, S.B., and Selverstone, J., 1998, Hydrothermal uranium deposits containing molybdenum and fluorite in the Marysvale volcanic field, west-central Utah: Mineralium Deposita, v. 33, p. 477-494.

Cunningham, C.G., Rye, R.O., Rockwell, B.W., Kunk, M.J., and Councell, T.B., 2005, Supergene destruction of a hydrothermal replacement alunite deposit at Big Rock Candy Mountain, Utah-Mineralogy, spectroscopic remote sensing, stable-isotope and argon-age evidences: Chemical Geology, v.215, nos. 1-4, p.317-337; available at URL http://dx.doi.org/10.1016/j.chemgeo.2004.06.055. 
Cunningham, C.G., Rye, R.O., Steven, T.A., and Mehnert, H.H., 1984, Origins and exploration significance of replacement and vein-type alunite deposits in the Marysvale volcanic field, west central Utah: Economic Geology, v. 79, p. 50-71.

Cunningham, C.G., Steven, T.A., and Naeser, C.W., 1978, Preliminary structural and mineralogical analysis of the Deer Trail Mountain-Alunite Ridge mining area, Utah: U.S. Geological Survey Open-File Report 78-314, 1 sheet.

Dalton, J.B., King, T.V.V., Bove, D.J., Kokaly, R.F., Clark, R.N., Vance, J.S., and Swayze, G.A., 2000, Distribution of acid-generating and acid-buffering minerals in the Animas River watershed as determined by AVIRIS spectroscopy, in ICARD 2000; Proceedings of the Fifth International Conference on Acid Rock Drainage: Littleton, Colorado, Society for Mining, Metallurgy, and Exploration, Inc., p. 1541-1550; available at URL http://speclab.cr.usgs.gov/ PAPERS/animas1999/animas.html (last accessed 8 September 2004).

Davis, L.E., Webster, G.D., and Dyman, T.S., 1994, Correlation of the West Canyon, Lake Point, and Bannock Peak Limestones (Upper Mississippian to Middle Pennsylvanian), basal formations of the Oquirrh Group, northern Utah and southeastern Idaho: U.S. Geological Survey Bulletin 2088, 30 p.

Desborough, G.A., Briggs, P.H., and Mazza, Nilah, 1998, Chemical and mineralogical characteristics and acid-neutralizing potential of fresh and altered rocks and soils of the Boulder River headwaters in Basin and Cataract Creeks of northern Jefferson County, Montana: U.S. Geological Survey Open-File Report 98-40; available at URL http://pubs. usgs.gov/of/1998/ofr-98-0040/ (last accessed 8 September 2004).

Desborough, G.A., Leinz, R.W., Smith, K.S., Hageman, P.L., Fey, D.L., and Nash, J.T., 1999, Acid generation and metal mobility of some metal-mining related wastes in Colorado: U.S. Geological Survey Open-File Report 99-0322, 18 p.

Desborough, G.A., Leinz, R.W., Sutley, S.J., Smith, K.S., and Breit, G.N., 2000, Leaching studies of schwertmannite-rich precipitates from the Animas River headwaters, Colorado and Boulder River headwaters, Montana: U.S. Geological Survey Open-File Report 00-004, 19 p.

Ebert, S.W., and Rye, R.O., 1997, Secondary precious metal enrichment by steam-heated fluids in the Crofoot-Lewis hot spring gold-silver deposit and relation to paleoclimate: Economic Geology, v. 92, p. 578-600.

Farrand, W.H., and Harsanyi, J.C., 1997, Mapping the distribution of mine tailings in the Coeur d'Alene River Valley, Idaho, through the use of a constrained energy minimization technique: Remote Sensing of Environment, v. 59, p. 64-76.
Ferris, F.G., Tazaki, K., and Fyfe, W.S., 1989, Iron oxides in acid mine drainage environments and their association with bacteria: Chemical Geology, v. 74, p. 321-330.

Gao, B.C., and Goetz, A.F.H., 1990, Column atmospheric water vapor and vegetation liquid water retrievals from airborne imaging spectrometer data: Journal of Geophysical Research, v. 95, p. 3549-3564.

Gao, B.C., Heidebrecht, K.B., and Goetz, A.F.H., 1992, ATmospheric REMoval program (ATREM) user's guide: Boulder, Colo., University of Colorado, Center for the Study of Earth from Space, version 1.1, 24 p.

Gilluly, James, 1932, Geology and ore deposits of the Stockton and Fairfield Quadrangles, Utah: U.S. Geological Survey Professional Paper 173, 171 p.

Hannah, J.L., and Macbeth, A.P., 1990, Magmatic history of the East Tintic Mountains, Utah: U.S. Geological Survey Open-File Report 90-0095, 24 p., 1 plate, scale 1:24,000.

Hannah, J.L., Stein, H.J., and Macbeth, A.P., 1990, A caldera in the East Tintic Mountains, Utah-Field relations between Tertiary magmatism and Tintic-type ore deposits, in Geology and ore deposits of the Great Basin, Reno/Sparks, Nevada: Geological Society of Nevada and U.S. Geological Survey, 1990 Program with Abstracts, p. 63.

Hannah, J.L., Stein, H.J., and Macbeth, A.P., 1991, Field relations between Tertiary magmatism and Tintic-type ore deposits, East Tintic Mountains, Utah, in Raines, G.L., Lisle, R.E., Schafter, R.W., and Wilkinson, W.H., eds., Geology and ore deposits of the Great Basin: Geological Society of Nevada, Symposium Proceedings, v. 1, p. 28-34.

Hurlbut, C.S., Jr., and Klein, C., 1977, Manual of mineralogy, Nineteenth Edition: New York, John Wiley, 532 p.

ICF Technology Incorporated, 1989, Mercur Canyon outwash site investigation report, executive summary: U.S. Bureau of Land Management, Region VIII, Site Investigation, 24 p.

John, D.A., and Ballantyne, G.H., eds., 1997, Geology and ore deposits of the Oquirrh and Wasatch Mountains, Utah: Society of Economic Geologists Guidebook Series, v. 29, 256 p.

Kerr, P.F., Brophy, G.P., Dahl, H.M., Green, J., and Woolard, L.E., 1957, Marysvale, Utah, uranium area: Geological Society of America Special Paper 64, 212 p.

King, T.V.V., Clark, R.N., and Swayze, G.A., 2000, Applications of imaging spectroscopy data-A case study at Summitville, Colorado, in Kuehn, F., King, T., Hoerig, B., and Pieters, D., eds., Remote sensing for site characterization: Berlin, Springer, p. 164-185. 
Kokaly, R.F., and Clark, R.N., 1999, Spectroscopic determination of leaf biochemistry using band-depth analysis of absorption features and stepwise multiple linear regression: Remote Sensing of Environment, v. 67, p. 267-287.

Kokaly, R.F., Rockwell, B.W., Morath, L., Root, R.R., and Goodman, S., 2002, Post-fire characterization of the land surface and vegetation using imaging spectroscopy data for Cerro Grande, NM and Left Hand Creek, WY: Abstract and poster presentation, Third USGS Fire Science Workshop, Lakewood, Colorado, U.S.A., November 12-15, 2002; available at URL http://firescience.cr.usgs.gov/html/kokaly_ abs02.html (last accessed 8 September 2004).

Koschmann, A.H., and Bergendahl, M.H., 1968, Principal gold-producing districts of the United States: U.S. Geological Survey Professional Paper 610, 283 p.

Krahulec, K.A., 1996, Geology and geochemistry of the SWT porphyry copper system, Tintic mining district, Juab County, Utah, in Green, S.M., and Struhsacker, E., eds., Geology and ore deposits of the American Cordillera, Field Trip Guidebook Compendium, Sparks, Nevada, April 10-13, 1995: Reno, Nev., Geological Society of Nevada, p. $62-78$.

Lindgren, W., 1906, The Annie Laurie mine, Piute County, Utah: U.S. Geological Survey Bulletin 285, p. 87-90.

Lovering, T.S., 1949, Rock alteration as a guide to ore-East Tintic district, Utah: Economic Geology Monograph 1, $65 \mathrm{p}$.

Lovering, T.S., 1960, Geologic and alteration maps of the East Tintic district, Utah: U.S. Geological Survey Mineral Investigations Field Studies Map MF-0230, 2 sheets, scale $1: 9,600$.

Mako, D.A., 1999, A post-mining view of the Mercur gold district, Tooele County, Utah, in Geology and ore deposits at Bingham Canyon, Barney's Canyon, Mercur and adjacent districts in the Oquirrh Range: Geological Society of Nevada Special Publication 30, p. 89-139.

McDougal, R.R., Clark, R.N., Livo, K.E., Kokaly, R.F., Rockwell, B.W., and Vance, J.S., 1999, Preliminary mineral mapping in the Oquirrh Mountains region for the Utah EPA Project using AVIRIS data, in Green, R.O., ed., Summaries of the Eighth Annual JPL Airborne Earth Science Workshop, NASA JPL AVIRIS Workshop, Pasadena, California, U.S.A., February 8-11: Pasadena, California, JPL Publication 99-17, p. 291-298; available at URL http://speclab. cr.usgs.gov/earth.studies/Utah-1/Jpl_pap.wpd.html (last accessed 8 September 2004).
Morris, H.T., 1968, The main Tintic mining district, Utah, in Ridge, J.D., ed., Ore deposits of the United States, 19331967 (the Graton-Sales volume): New York, American Institute of Mining, Metallurgical and Petroleum Engineers, v. 2, p. 1044-1073.

Morris, H.T., 1975, Geologic map and sections of the Tintic Mountain Quadrangle and adjacent part of the McIntyre Quadrangle, Juab and Utah Counties, Utah: U.S. Geological Survey Miscellaneous Investigations Series Map I-883, scale 1:24,000.

Morris, H.T., 1990, Gold in the Tintic mining district, Utah: U.S. Geological Survey Bulletin 1857-F, p. F1-F11.

Morris, H.T., and Lovering, T.S., 1961, Stratigraphy of the East Tintic Mountains, Utah: U.S. Geological Survey Professional Paper 361, 145 p.

Morris, H.T., and Mogensen, A.P., 1978, Tintic mining district, Juab and Utah Counties, Utah, in Shawe, D.R., ed., Guidebook to mineral deposits of the central Great Basin: Nevada Bureau of Mines and Geology Report 32, p. 69-75.

Nash, J.T., 2002, Flood deposits of transported mill tailings in Nevada and Utah_Evidence for tailings dam failures and implications for risk assessment: U.S. Geological Survey Open-File Report 02-431, 85 p.

Rockwell, B.W., 2004, Spectral variations in rocks and soils containing ferric iron hydroxide and (or) sulfate minerals as seen by AVIRIS and laboratory spectroscopy: U.S. Geological Survey Open-File Report 2004-1431, 24 p.; available at URL http://pubs.usgs.gov/of/2004/1431/ (last accessed 26 January 2005).

Rockwell, B.W., 2002, Descriptions, spectral plots, and digital spectra of samples applied to spectral analysis of imaging spectroscopy data-Utah (East Tintic Mountains, Oquirrh Mountains, Wasatch Mountains, and Tushar Mountains), Nevada (Goldfield Hills), and New Mexico (Jemez Mountains), U.S.A., 1999-2002: U.S. Geological Survey OpenFile Report 02-407; available at URL http://pubs.usgs. gov/of/2002/ofr-02-407/ (last accessed 8 September 2004).

Rockwell, B.W., Clark, R.N., Cunningham, C.G., Sutley, S.J., Gent, C., McDougal, R.R., Livo, K.E., and Kokaly, R.F., 2000, Mineral mapping in the Marysvale volcanic field, Utah using AVIRIS data, in Green, R.O., ed., Summaries of the Ninth Annual JPL Airborne Earth Science Workshop, NASA JPL AVIRIS Workshop, Pasadena, California, U.S.A., February 23-25: JPL Publication 00-18, p. 407417; available at URL http://speclab.cr.usgs.gov/earth.studies/ Utah-1/marysvale_JPL2000_final.pdf and ftp://popo.jpl. nasa.gov/pub/docs/workshops/00_docs/Rockwell_web.pdf (last accessed 8 September 2004). 
Rockwell, B.W., Clark, R.N., Livo, K.E., McDougal, R.R., and Kokaly, R.F., 2002, AVIRIS data calibration informationOquirrh and East Tintic Mountains, Utah: U.S. Geological Survey Open-File Report 02-0200; available at URL http:// greenwood.cr.usgs.gov/pub/open-file-reports/ofr-02-0200/ (last accessed 8 September 2004).

Rockwell, B.W., Clark, R.N., Livo, K.E., McDougal, R.R., Kokaly, R.F., and Vance, J.S., 1999, Preliminary materials mapping in the Park City region for the Utah USGS-EPA Imaging Spectroscopy Project using both high and low altitude AVIRIS data, in Green, R.O., ed., Summaries of the Eighth Annual JPL Airborne Earth Science Workshop, NASA JPL AVIRIS Workshop, Pasadena, California, U.S.A., February 8-11: Pasadena, California, JPL Publication 99-17, p. 365-375; available at URL http://speclab. cr.usgs.gov/earth.studies/Utah-1/park_cityAV5.html or ftp://popo.jpl.nasa.gov/pub/docs/workshops/99_docs/51.pdf (last accessed 8 September 2004).

Rowley, P.D., Cunningham, C.G., Steven, T.A., Menhert, H.H., and Naeser, C.W., 1998, Cenozoic igneous and tectonic setting of the Marysvale volcanic field and its relation to other igneous centers in Utah and Nevada, in Friedman, J.D., and Huffman, A.C., Jr., eds., Laccolith complexes of southeastern Utah-Time of emplacement and tectonic setting-Workshop proceedings: U.S. Geological Survey Bulletin 2158, p. 167-201.

Rowley, P.D., Cunningham, C.G., Steven, T.A., Workman, J.B., Anderson, J.J., and Theissen, K.M., 2002, Geologic map of the central Marysvale volcanic field, southwestern Utah: U.S. Geological Survey Geologic Investigations Series I-2645-A, scale 1:100,000; available at URL http:// greenwood.cr.usgs.gov/pub/i-maps/i-2645-a/ (last accessed 8 September 2004).

Rowley, P.D., Menhert, H.H., Naeser, C.W., Snee, L.W., Cunningham, C.G., Steven, T.A., Anderson, J.J., Sable, E.G., and Anderson, R.E., 1994, Isotopic ages and stratigraphy of Cenozoic rocks of the Marysvale volcanic field and adjacent areas, west-central Utah: U.S. Geological Survey Bulletin 2071, 35 p.

Rye, R.O., and Alpers, C.N., 1997, The stable isotope geochemistry of jarosite: U.S. Geological Survey Open-File Report 97-0088, 28 p.

Rye, R.O., Bethke, P.M., and Wasserman, M.D., 1992, The stable isotope geochemistry of acid sulfate alteration: Economic Geology, v. 87, p. 225-262.
Smith, K.S., Crock, J.G., Desborough, G.A., Fitterman, D.V., Leinz, R.W., Montour, M.R., Stanton, M.R., Swayze, G.A., and Vaughn, R.B., 1998, An overview of the U.S. Geological Survey Mine Waste Characterization Project-Science for Watershed Decisions on Abandoned Mine LandsReview of preliminary results, Denver, Colorado, February 4-5, 1998: U.S. Geological Survey Open-File Report 98297; available at URL http://amli.usgs.gov/reports/ofr98_ 297/smith.html (last accessed 8 September 2004).

Steven, T.A., and Morris, H.T., 1983, Geologic map of the Cove Fort quadrangle, west-central Utah: U.S. Geological Survey Miscellaneous Investigations Map I-1481, scale $1: 50,000$.

Stoeser, D.B., 1993, Tertiary calderas and regional extension of the east-central part of the Tintic-Deep Creek mineral belt, eastern Great Basin, Utah, in Scott, R.W., Jr., Detra, P.S., and Berger, B.R., eds., Advances related to United States and international mineral resources-Developing frameworks and exploration technologies: U.S. Geological Survey Bulletin 2039, p. 5-23.

Stoffregen, R.E., 1993, Stability relations of jarosite and natrojarosite at $10-250^{\circ} \mathrm{C}$ : Geochimica et Cosmochimica Acta, v. 57, p. 2417-2429.

Swayze, G.A., Smith, K.S., Clark, R.N., Sutley, S.J., Pearson, R.M., Vance, J.S., Hageman, P.L., Briggs, P.H., Meier, A.L., Singleton, M.J., and Roth, S., 2000, Using imaging spectroscopy to map acidic mine waste: Environmental Science and Technology, v. 34, p. 47-54; available at URL http:// speclab.cr.usgs.gov/PAPERS/leadville99/ldv99.html (last accessed 8 September 2004).

Tooker, E.W., and Roberts, R.J., 1970, Upper Paleozoic rocks in the Oquirrh Mountains and Bingham mining district, Utah: U.S. Geological Survey Professional Paper 629-A, p. A1-A76.

UNICO Incorporated, 2003: Available at URL http://www. uncn.com/ (last accessed 8 September 2004).

U.S. Environmental Protection Agency, 2001, Eureka Mills, Eureka, Utah, Risk Assessment Fact Sheet: Available at URL http://www.epa.gov/region08/superfund/sites/Eureka_ Fact_Sheet.pdf(last accessed 8 September 2004).

U.S. Environmental Protection Agency, 2002a, Eureka Mills, Utah [Superfund Web site]: Available at URL http://www. epa.gov/region08/superfund/sites/ut/eureka.html (last accessed 8 September 2004).

U.S. Environmental Protection Agency, 2002b, International Smelter and Refining [Superfund Web site]: Available at URL http://www.epa.gov/region8/superfund/sites/ut/intnsmlt.html (last accessed 8 September 2004). 
U.S. Environmental Protection Agency, 2002c, Kennecott South [Superfund Web site]: Available at URL http://www. epa.gov/region08/superfund/sites/ut/kennes.html (last accessed 8 September 2004).

U.S. Environmental Protection Agency and U.S. Geological Survey, 2002, Utah Abandoned Mine Lands Imaging Spectroscopy Project: Available at URL http://speclab. cr.usgs.gov/earth.studies/Utah-1/utah-1.html (last accessed 8 September 2004).

Vane, G., ed., 1987, Airborne Visible/infrared Imaging Spectrometer (AVIRIS) - Description of the sensor, data, ground processing facility, laboratory calibration, and first results, California Institute of Technology, Pasadena, California, November 15, 1987: NASA Jet Propulsion Laboratory Publication 87-38; see general AVIRIS Web site, http://aviris. jpl.nasa.gov/ (last accessed 8 September 2004).

Watson, D., 1992, Contouring - A guide to the analysis and display of spatial data: Oxford, Pergamon Press, 321 p.
Willard, M.E., and Proctor, P.D., 1946, White Horse alunite deposit, Marysvale, Utah: Economic Geology, v. 41, p. 619-643.

Winkler, H.G.F., 1979, Petrogenesis of metamorphic rocks (5th ed.): New York, Springer-Verlag, 348 p.

\section{Appendix. X-Ray Diffraction Results}

Appendix tables A1-A3 give results of XRD analysis for the Tintic mining district, the Mercur outwash area in the southwestern Oquirrh Mountains, and the Tushar Mountains/ Marysvale region, respectively. Field XRF data for the Mercur outwash area are also given in appendix table A2. XRD analyses were performed by Carol A. Gent and Stephen J. Sutley of the U.S. Geological Survey. All latitude and longitude coordinates are relative to the NAD27 horizontal datum.

Appendix Table 1. XRD analysis results-Tintic mining district, Utah.

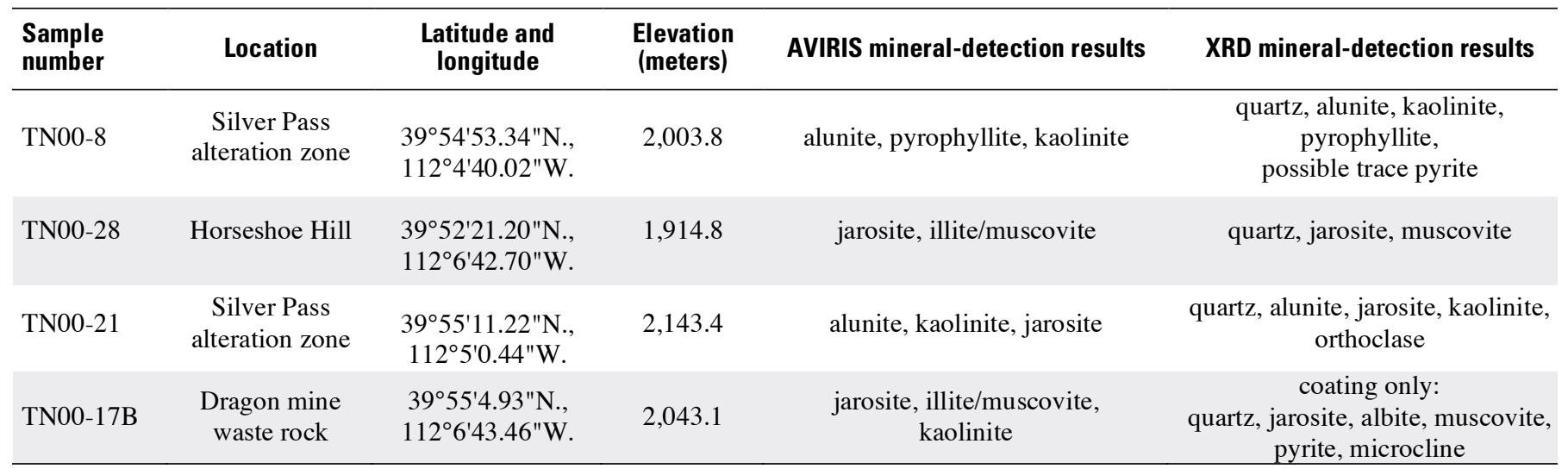


Appendix Table 2. XRD analysis results and field XRF data-Mercur outwash, southwestern Oquirrh Mountains, Utah.

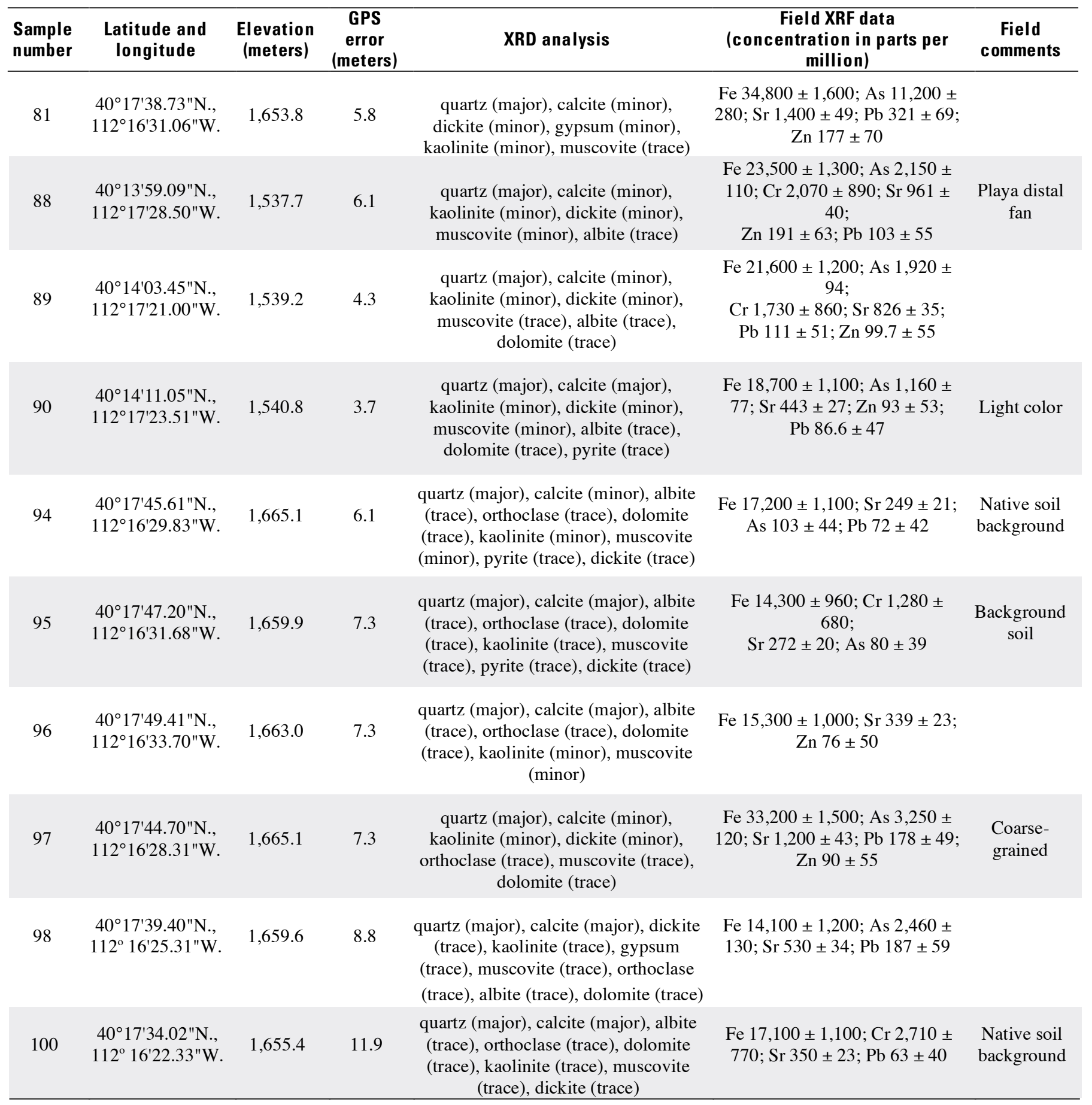




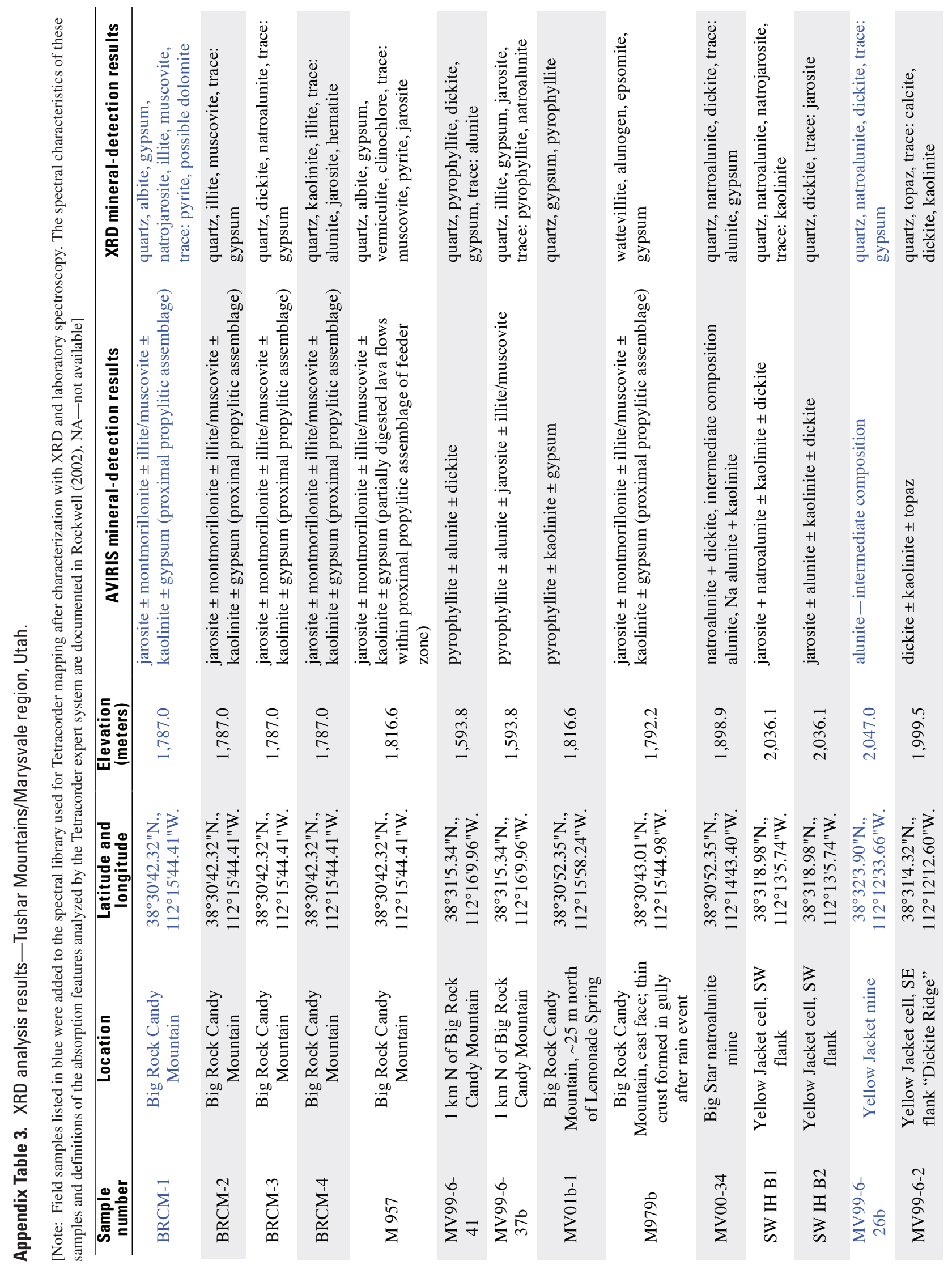




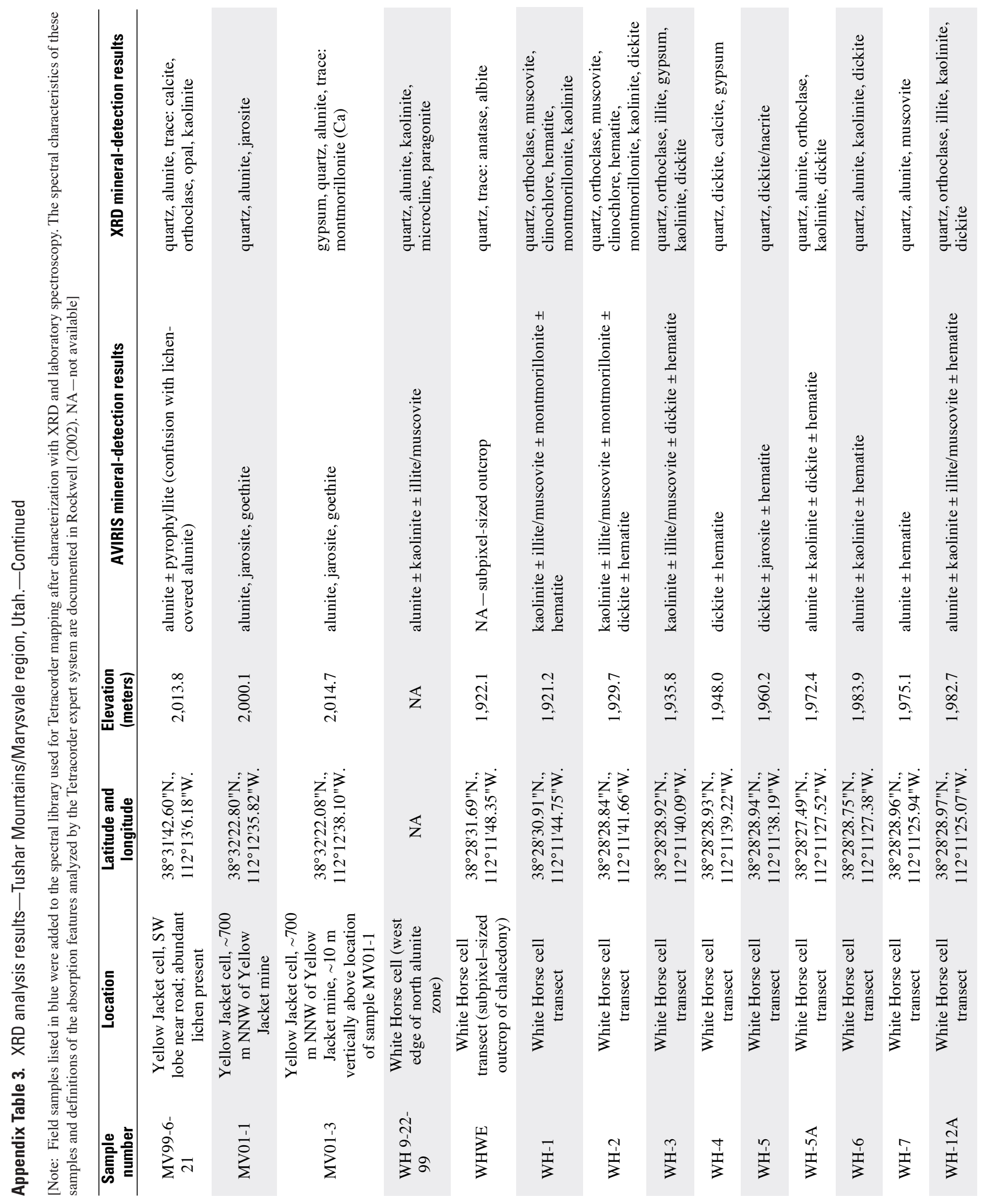




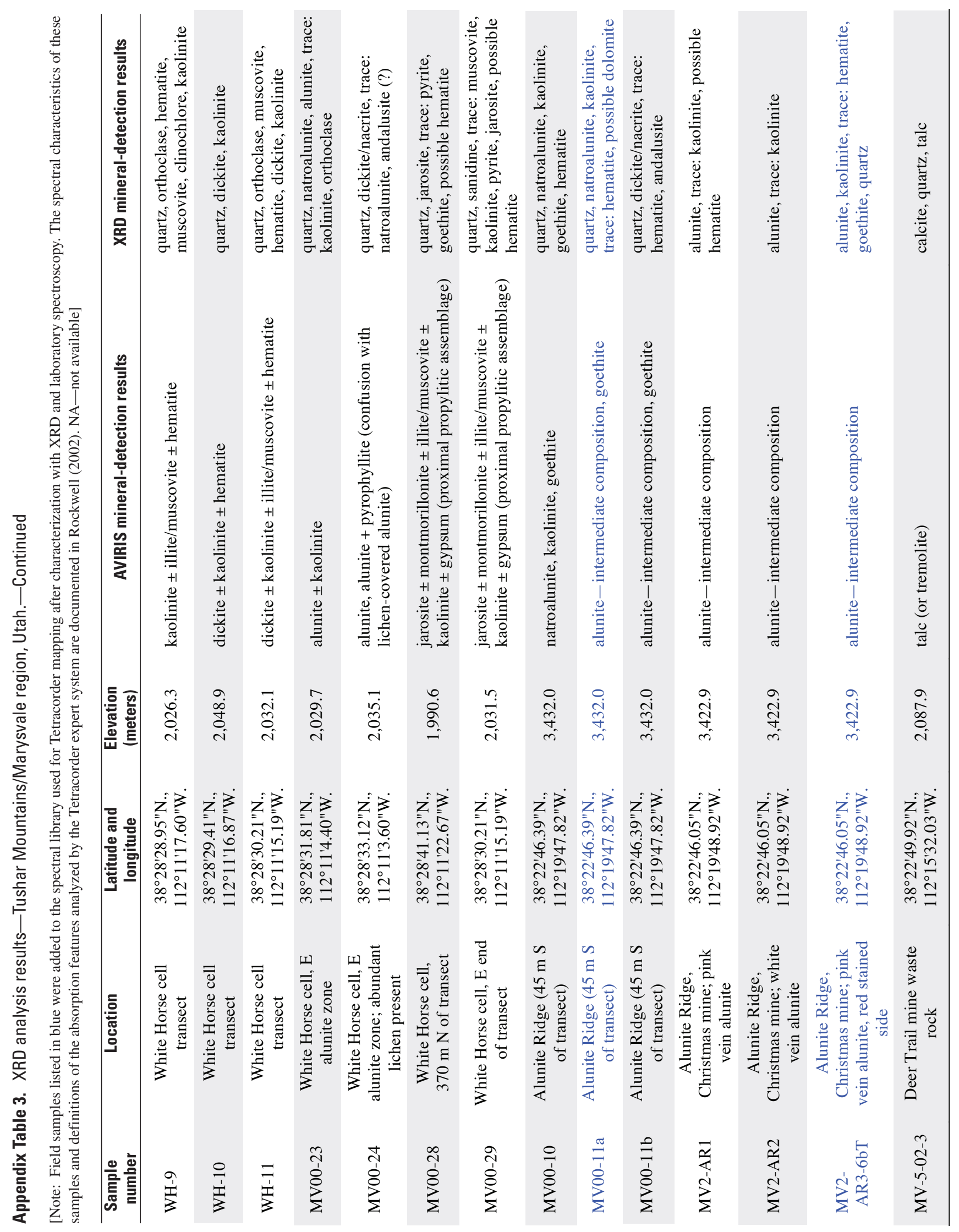

